\title{
Ecology And Management Of Golden-Winged Warblers (Vermivora Chrysoptera) And Associated Avian Species In The Allegheny Mountains Of West Virginia
}

Kyle R. Aldinger

Follow this and additional works at: https://researchrepository.wvu.edu/etd

\author{
Recommended Citation \\ Aldinger, Kyle R., "Ecology And Management Of Golden-Winged Warblers (Vermivora Chrysoptera) And \\ Associated Avian Species In The Allegheny Mountains Of West Virginia" (2018). Graduate Theses, \\ Dissertations, and Problem Reports. 7152. \\ https://researchrepository.wvu.edu/etd/7152
}

This Dissertation is protected by copyright and/or related rights. It has been brought to you by the The Research Repository @ WVU with permission from the rights-holder(s). You are free to use this Dissertation in any way that is permitted by the copyright and related rights legislation that applies to your use. For other uses you must obtain permission from the rights-holder(s) directly, unless additional rights are indicated by a Creative Commons license in the record and/ or on the work itself. This Dissertation has been accepted for inclusion in WVU Graduate Theses, Dissertations, and Problem Reports collection by an authorized administrator of The Research Repository @ WVU. For more information, please contact researchrepository@mail.wvu.edu. 


\title{
ECOLOGY AND MANAGEMENT OF GOLDEN-WINGED WARBLERS (VERMIVORA CHRYSOPTERA) AND ASSOCIATED AVIAN SPECIES IN THE ALLEGHENY MOUNTAINS OF WEST VIRGINIA
}

\author{
Kyle R. Aldinger \\ Dissertation submitted \\ to the Davis College of Agriculture, Natural Resources, and Design \\ at West Virginia University \\ in partial fulfillment of the requirements for the degree of \\ Doctor of Philosophy in \\ Forest Resource Science
}

Petra B. Wood, Ph.D., Chair

James T. Anderson, Ph.D.

Catherine M. Johnson, Ph.D.

George T. Merovich, Ph.D.

Michael P. Strager, Ph.D.

Wildlife and Fisheries Resources Program,

Division of Forestry and Natural Resources

Morgantown, West Virginia

2018

Keywords: breeding season, cattle, community, conservation, density, dispersal, disturbance, elevation, forest, grazing, habitat, nest, pasture, population, shrub, spatial, succession, survival

Copyright 2018 Kyle R. Aldinger 


\title{
ABSTRACT \\ ECOLOGY AND MANAGEMENT OF GOLDEN-WINGED WARBLERS (VERMIVORA CHRYSOPTERA) AND ASSOCIATED AVIAN SPECIES IN THE ALLEGHENY MOUNTAINS OF WEST VIRGINIA
}

\author{
Kyle R. Aldinger
}

This dissertation focuses on the breeding season ecology and management of Goldenwinged Warblers (Vermivora chrysoptera) in the Allegheny Mountains of West Virginia with implications for other disturbance-dependent avian species. Golden-winged Warblers have a complex life history, requiring dynamic forest landscapes with varying age classes for breeding. Populations breeding in the Appalachian Mountains are among the most rapidly decreasing among vertebrates in eastern North America. For these reasons, much research already has been completed on Golden-winged Warblers. Nonetheless, we still have a limited understanding of the causes of population decreases and these causes may vary regionally. I organized this dissertation into 3 parts (Part 1: Introduction, Part 2: Golden-winged Warbler Ecology, Part 3: Golden-winged Warbler Management) including 6 chapters that follow a progression of accumulating knowledge on Golden-winged Warbler population decreases in the Allegheny Mountains of West Virginia.

Part 1 includes chapter 1 and is an introduction to the dissertation. In chapter $1, \mathrm{I}$ provided a brief introduction and justification for my research, placed the dissertation into the context of ongoing Golden-winged Warbler research across the species’ range, and outlined the dissertation content. Through impressive collaborative efforts, our understanding of Goldenwinged Warbler ecology and management grew substantially during 2008-2016, the period during which this research took place.

Part 2 includes chapters 2-4 and focuses on Golden-winged Warbler ecology with an overall objective of filling knowledge gaps for the species to enhance conservation efforts and inform future research. In chapter 2, I evaluated variables at multiple spatial scales during 20082015 to identify conditions that supported high densities of breeding Golden-winged Warblers and associated avian species. Spatial scales used for analyses represented annual dispersal (5-km radius), extra-territorial movement (1.5-km radius), intra-territorial movement (100-m radius), and local resource utilization (11.3-m radius). Golden-winged Warbler density peaked when the minimum elevation was $804 \mathrm{~m}$ at the 1.5 -km radius scale but was negatively associated with 
100-m radius minimum elevation. Density was positively associated with 100 -m radius shrubland cover. I identified White-eyed Vireo (Vireo griseus), Blue-gray Gnatcatcher (Polioptila caerulea), Gray Catbird (Dumetella carolinensis), Brown Thrasher (Toxostoma rufum), and Yellow Warbler (Setophaga petechia) as species most likely to benefit from management for Golden-winged Warblers. Golden-winged Warblers ordinated higher along the 100-m shrubland cover gradient than any other bird species, suggesting they may be the most shrubland area-sensitive songbird in my study area. However, the species also requires heavily forested landscapes. Therefore, a species-specific conservation strategy that balances shrubland (patches 9-13 ha comprising 15\% of the landscape) and contiguous forest area ( $\geq 75 \%$ of the landscape) could concurrently meet the needs of Golden-winged Warblers and many other avian species.

In chapter 3, I used a spatial Cormack-Jolly-Seber (s-CJS) model to obtain minimallybiased estimates of annual survival and breeding and natal dispersal for Golden-winged Warblers during 2008-2015, as well as for locally less abundant Blue-winged Warblers (V. cyanoptera) and their hybrids. Vermivora warbler annual survival did not vary by phenotype, sex, or study area, but adult annual survival $(0.53,95 \%$ confidence interval $[\mathrm{CI}]=0.46-0.60)$ was higher than juvenile annual survival (0.09, 0.05-0.13). Adjusting for mortality during the post-fledging period, juvenile annual survival may be about half of adult annual survival. Expected breeding dispersal (329 m, 316-344 m) was less than expected natal dispersal (544 m, 500-592 m) based on our s-CJS model. I observed the longest distances for natal dispersal (mean $=1,587 \mathrm{~m}$, median $=1,047 \mathrm{~m}, \mathrm{n}=18$ ), intermediate distances for second year to after second year dispersal (mean = $492 \mathrm{~m}$, median $=132 \mathrm{~m}, \mathrm{n}=46$ ), and the shortest distances for after second year dispersal (mean $\pm \mathrm{SE}=290 \mathrm{~m}$, median $=103 \mathrm{~m}, \mathrm{n}=103)$. Female $(716 \pm 162 \mathrm{~m}, \mathrm{n}=43)$ warblers tended to disperse farther than males $(404 \pm 64 \mathrm{~m}, \mathrm{n}=124)$. These results provide the first estimates of annual survival that account for permanent emigration and have important implications for conservation network design given our estimates of dispersal.

In chapter 4, I investigated the spatial configuration of shrubs within Golden-winged Warbler breeding territories using a combination of field-measured and light detection and ranging (LIDAR) vegetation data during 2011-2014. Golden-winged Warblers selected nest sites with more shrub cover (mean $\pm \mathrm{SE}=49.3 \pm 2.3 \%$ ) than random locations (mean $\pm \mathrm{SE}=42.9 \pm$ 2.9\%) but did not select for a particular shrub community configuration for nesting. The species 
selected territories with more pronounced edges ( $\geq 60 \%$ difference in shrub cover on either side of a given point) and a more clumped rather than dispersed or uniform shrub configuration (shrub clumps 4.6-22.6 m wide) than would be expected given a random configuration of shrubs, although selection was relatively weak. Selection for pronounced edges between shrub and non-shrub cover and clumped shrub configuration at the territory scale rather than the nest scale, despite strong evidence that Golden-winged Warblers placed nests along edges, suggests that the species may be selecting territories that maximize the number of potential nest sites in anticipation of re-nesting or to reduce predation risk (i.e., potential-prey-site hypothesis). Golden-winged Warbler nest sites had taller (mean height $=4.3 \mathrm{~m}$ ) and more variable (mean standard deviation of height $=3.1 \mathrm{~m}$ ) vegetation canopy height than random locations within the same territory. Across a Golden-winged Warbler territory, $40-52 \%$ of the tallest vegetation canopy was $\leq 1 \mathrm{~m}$ tall consisting of grasses, forbs, blackberry, and seedlings, 29-33\% of the vegetation canopy was $>1$ to $\leq 5 \mathrm{~m}$ tall consisting of shrubs and saplings, and $15-32 \%$ of the vegetation canopy was $>5$ to $\leq 20 \mathrm{~m}$ tall consisting of trees. I provide one of the first objective evaluations of the spatial configuration of Golden-winged Warbler nesting cover.

Part 3 includes chapters $5-6$ and focuses on Golden-winged Warbler management response. Chapter 5 focused on persistence of breeding Golden-winged Warblers and other disturbance-dependent bird species on pastures with varying amounts of time since abandonment and consequently varying stages of vegetative succession. During 2008-2014, I monitored cattle pastures with varying numbers of years since abandonment representing a 62-year chronosequence. Field Sparrow (Spizella pusilla) density peaked on active pastures, Goldenwinged Warbler density peaked 16-20 years after pasture abandonment and reached zero 33 years after abandonment, and shrubland-nesting bird species richness did not vary across the chronosequence. Herbaceous cover peaked on active pastures (0 years since abandonment) at $26 \%$ then declined linearly, shrubland cover peaked 18 years since abandonment at $49 \%$, and forest cover increased linearly to a peak of $86 \%$ at 59 years since abandonment. Thus, abandoned pastures in my study area provide breeding habitat for a stable number but changing composition of shrubland-nesting bird species for approximately 60 years, though conservation value likely is highest 0-33 years after abandonment. The number and abandonment rate of farms in West Virginia and regionally are historically low, suggesting that managing for shrubland-nesting birds on existing or recently-abandoned pastures is important but alone may not support 
population persistence. Thus, increased forest management practices may be needed to supplement breeding habitat on pastures, particularly $<2 \mathrm{~km}$ from existing pastures.

Finally, chapter 6 focused on Golden-winged Warbler population trends in response to habitat management on pastures during 2008-2014. Golden-winged Warblers did not change nest placement behavior ( $\mathrm{n}=109$ nests) because of mechanical vegetation management intended to maintain shrubland cover type on my pastures. Nest daily survival rate ( $\mathrm{n}=123$ nests) was higher on pastures in my southern study area than my northern study area and was positively associated with proportion of territory-scale actively-managed shrubland cover type, shrubland patch size, and nest- and territory-scale elevation. I found that local Golden-winged Warbler population trends were associated with pasture-scale nest survival, with a nest daily survival rate of 0.978 presumably needed to offset other mortality and achieve a stable population in my study. A strength of chapter 6 was that I observed variation in population trends and identified potential limiting factors across a small geographic area during the breeding season, meaning birds were likely experiencing similar conditions during the non-breeding season.

Overall, my findings help to justify, inform, and adapt state and regional Golden-winged Warbler conservation efforts during the breeding season. These findings also fill knowledge gaps and complement other novel research on Golden-winged Warbler throughout their breeding range. 


\section{ACKNOWLEDGMENTS}

I have many to thank for their contributions to this product, which is the culmination of a thesis, a dissertation, and 10 years of work. Our work together during this time also has contributed to six major multi-state, multi-organization collaborative efforts and numerous other side-projects primarily intended to better-understand and conserve the Golden-winged Warbler. I first thank my graduate advisor Dr. Petra Wood, with whom I have developed a special bond during my long tenure as a graduate student at West Virginia University. Petra provided a combination of instruction and personal autonomy that were extremely valuable in my professional growth. I thank her for trusting me to finish what we started even after I entered the workforce in 2015. I thank Dr. Jim Anderson, Dr. Cathy Johnson, Dr. George Merovich, Dr. Mike Strager, and Rob Tallman for serving on my graduate committees during my time at WVU. Their expertise was invaluable across many facets of this endeavor. Many members of the Golden-winged Warbler Working Group played instrumental roles in my thesis and dissertation. I also thank Dr. Peter Sólymos and Dr. Chris Rota for their help with statistical analyses.

The West Virginia Division of Natural Resources Wildlife Diversity Program [grant number 013555.2.1000502W], U.S. Fish and Wildlife Service Migratory Bird Program [grant number F12AP00643], U.S. Forest Service Monongahela National Forest [grant number 12-PA11092100-020], U.S. Natural Resources Conservation Service [grant number 68-7482-12-502], and National Fish and Wildlife Foundation [grant number 10012877.1.1004706R] granted funding for this research. The West Virginia Cooperative Fish and Wildlife Research Unit and West Virginia University also provided support. I owe a special thanks to Becky Nestor with the Coop Unit for her support and friendship. The Littlefield family, West Virginia Cooperative Fish and Wildlife Research Unit, and West Virginia Division of Natural Resources Elkins Operation Center provided housing. Numerous private landowners, the USDA Forest Service Monongahela National Forest, and West Virginia Division of Natural Resources allowed access to study sites.

I shared time with many great graduate students over the years, but I want to specifically acknowledge Joni Aldinger, Dr. Doug Becker, Ryan Davis, Dr. Laura Farwell, Mack Frantz, Dr. Greg George, Patrick McElhone, D.J. McNeil, Jeremy Mizel, Gretchen Nareff, Lee Ann Nolan, Dr. Jim Sheehan, Matt Shumar, and Dustin Smith for their advice, camaraderie, commiseration, and friendship. I especially valued the many conversations with D.J. McNeil about warblers, 
katydids, llamas, ecology, grad school, and life in general. Dr. Doug Becker, Dr. Greg George, and Matt Shumar mentored me prior to and early in graduate school and played an important role in my admission to WVU.

I am indebted to an army of field technicians and volunteers who collected data: Joni Aldinger, Ian Batterman, Paul Bryant, Cheyenne Carter, Alex Dalton, Mack Frantz, Chad Fitzmorris, Melissa Gallagher, Chris Gatti, Nick Glover, Dan Graham, Jerry Kreiser, Collette Lauzau, Katie Loucks, Stephanie Malinich, Molly McDermott, Andy Newman, Vicki Olmstead, Katie Pratt, Melissa Roach, Christine Roy, Jacob Saborse, Carolyn Sedgwick, Matt Shumar, Lisa Smith, Liz Stout, Dan Ware, and Mandy Weston. I am especially grateful to Jerry Kreiser (7 seasons), Jacob Saborse (2 seasons), and Mandy Weston (2 seasons) for their multiple seasons of work.

Finally, I could not have completed this dissertation without the love and support of my wife, Joni Aldinger, who appears multiple times in these acknowledgments! I'm excited to get to know her outside of the demands of graduate school (plus a full time job) and thank her for keeping our married life moving forward during this challenging time. I also thank the Aldinger and Riffle families for their love and support throughout my academic career so far.

This study was completed under the auspices of West Virginia University Institutional Animal Care and Use Committee protocols 07-0303 and 10-0201. 


\section{TABLE OF CONTENTS}

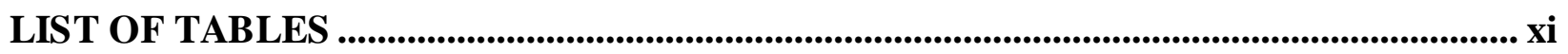

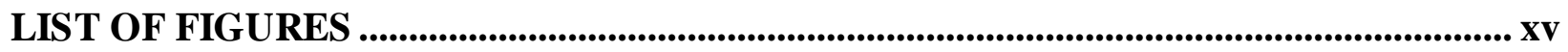

PART 1. GOLDEN-WINGED WARBLER INTRODUCTION .............................................. 1

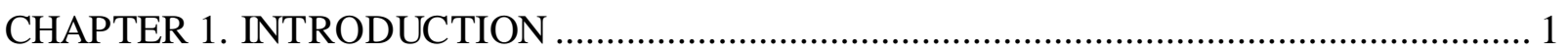

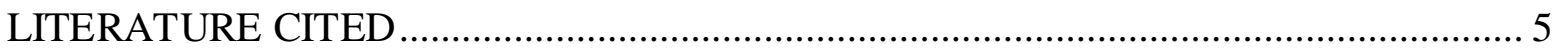

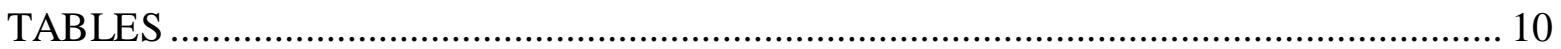

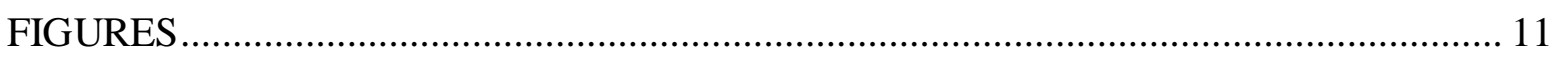

PART 2. GOLDEN-WINGED WARBLER ECOLOG Y ......................................................... 15

CHAPTER 2. REFINED CONSERVATION STRATEGIES FOR GOLDEN-WINGED WARBLERS IN THE WEST VIRGINIA HIGHLANDS WITH IMPLICATIONS FOR THE

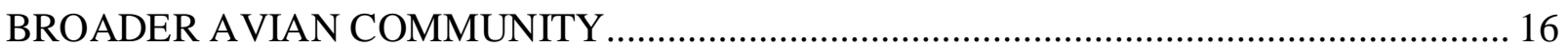

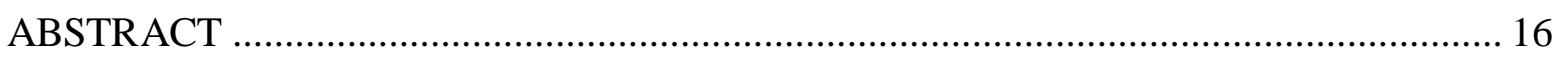

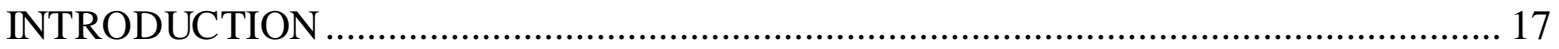

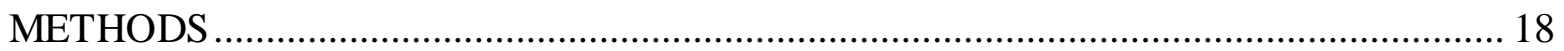

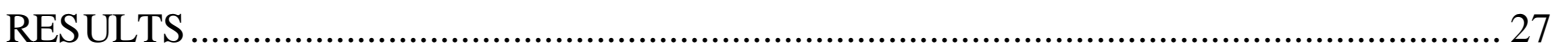

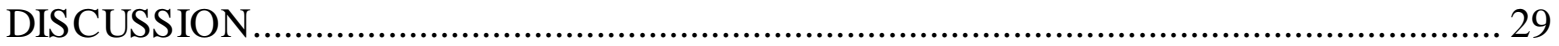

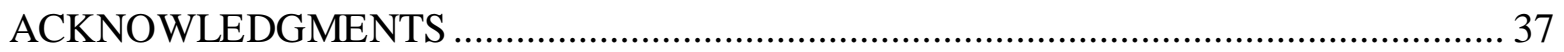

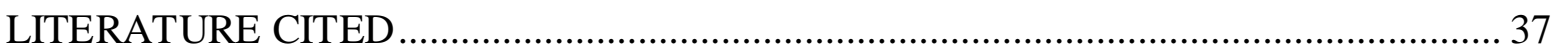

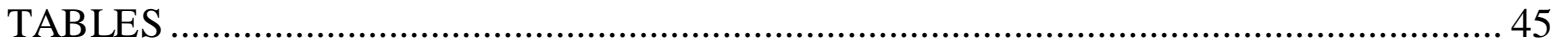

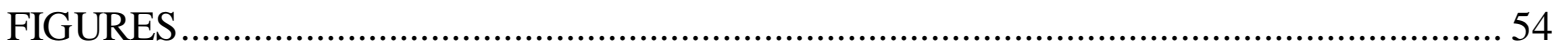

CHAPTER 3. MINIMALLY-BIASED ESTIMATES OF ANNUAL SURVIVAL AND DISPERSAL FOR BREEDING VERMIVORA WARBLERS IN WEST VIRGINIA ................ 61

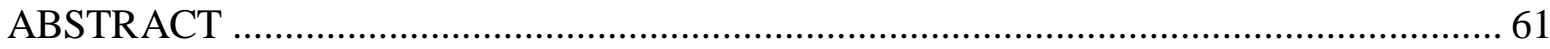

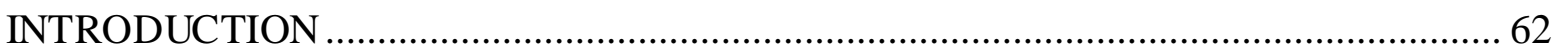

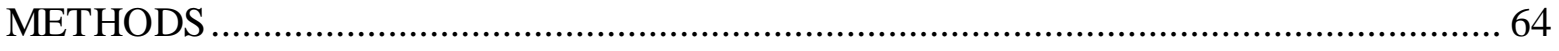

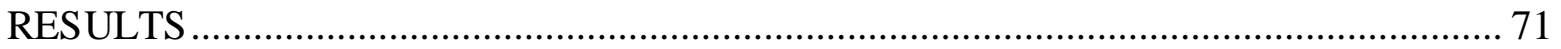

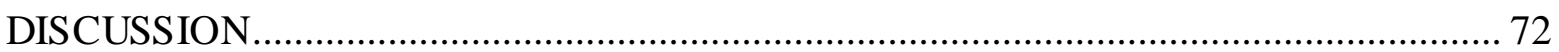

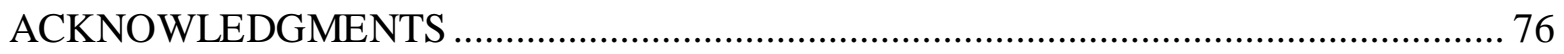

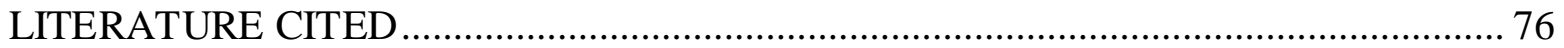

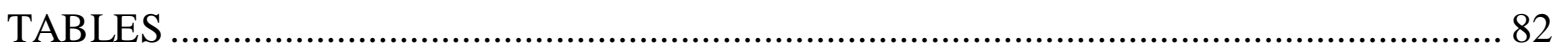

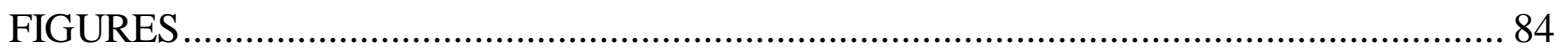


CHAPTER 4. GOLDEN-WINGED WARBLERS MAY SELECT NESTING TERRITORIES WITH NON-RANDOM SHRUB COMMUNITY CONFIGURATION ............................. 90

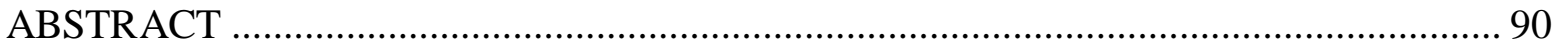

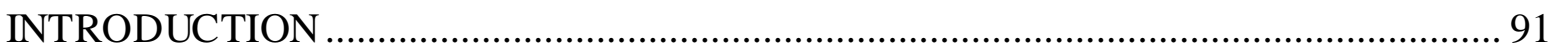

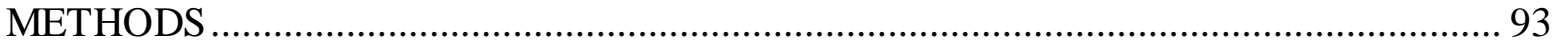

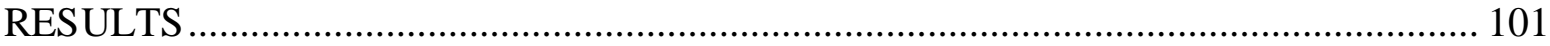

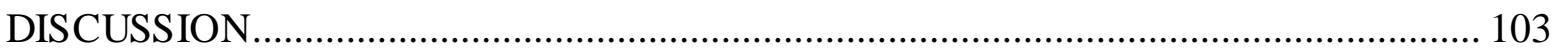

ACKNOWLEDGMENTS ……………………………………………………………... 108

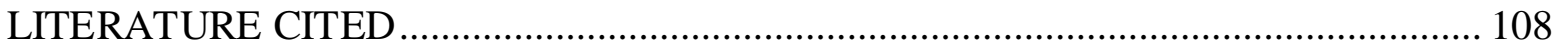

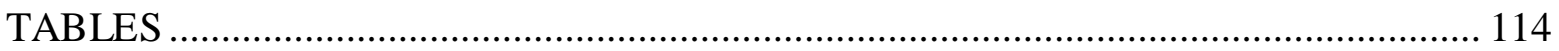

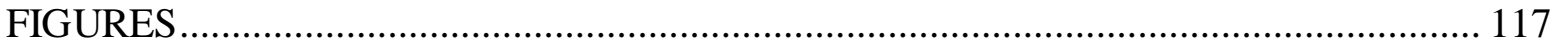

PART 3. GOLDEN-WINGED WARBLER MANAGEMENT ........................................... 125

CHAPTER 5. HOW LONG DO SHRUBLAND NESTING BIRDS PERSIST ON ABANDONED PASTURES?........................................................................................ 126

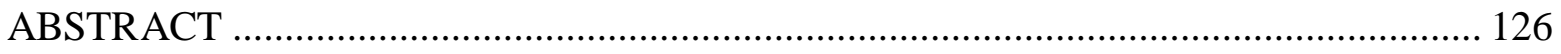

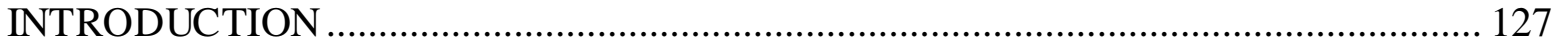

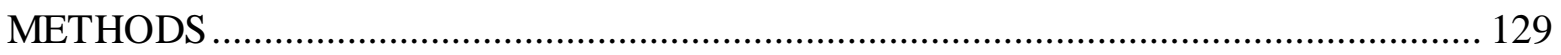

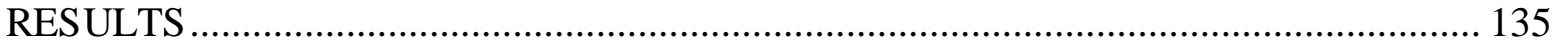

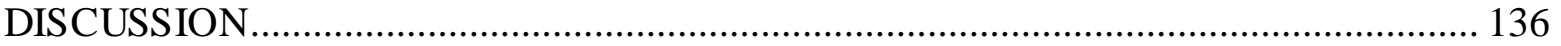

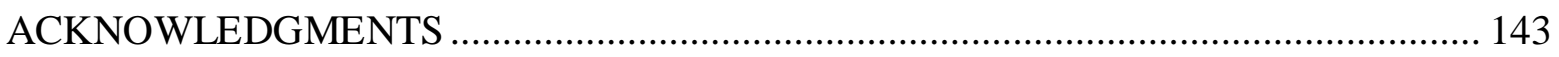

LITERATURE CITED .............................................................................................. 144

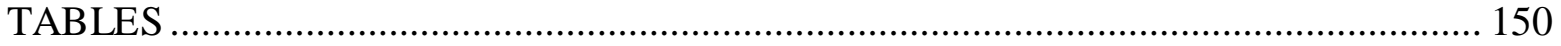

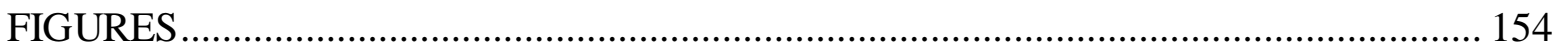

CHAPTER 6. HIGH NEST SURVIVAL DURING THE BREEDING SEASON MAY OFFSET OTHER LIMITING FACTORS FOR LOCAL POPULATIONS OF GOLDEN-

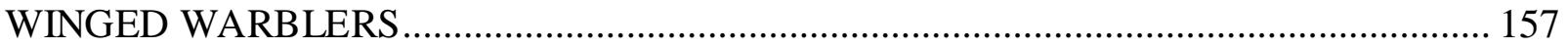

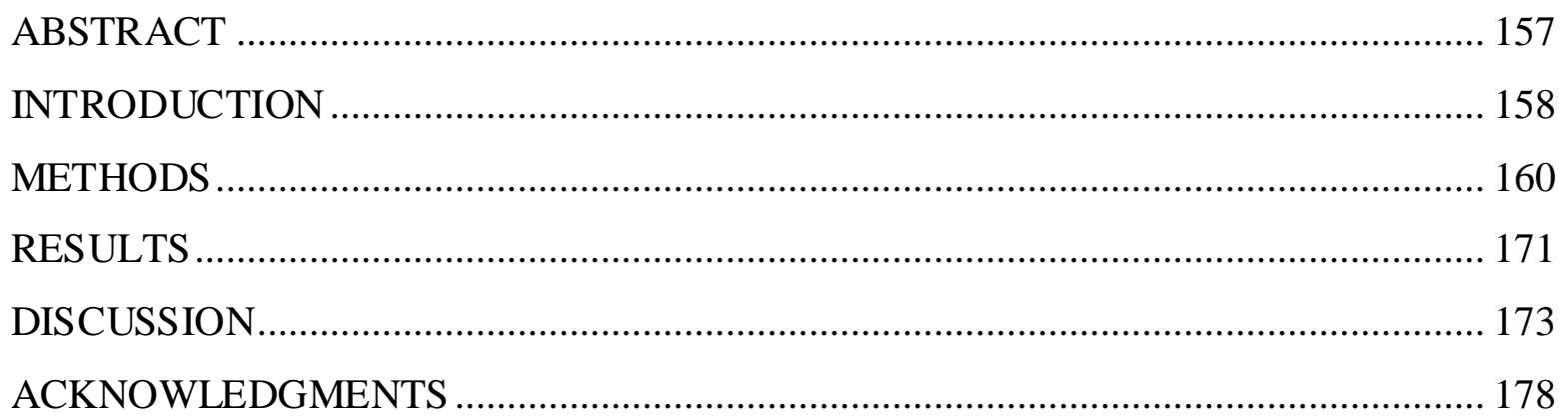




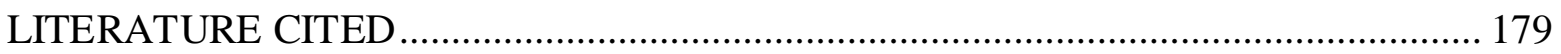

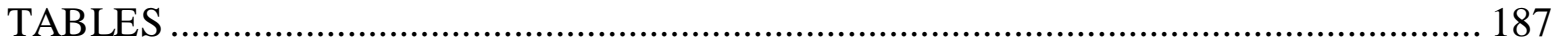

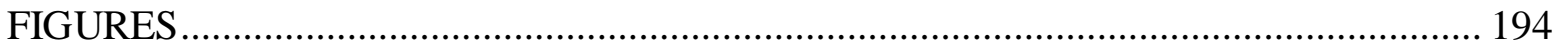




\section{LIST OF TABLES}

\section{CHAPTER 1. INTRODUCTION}

Table 1. Morphology of adult male and female Golden-winged Warblers captured at breeding sites with mist-nets during 27 April-27 June 2008-2016 in West Virginia. We measured body weight with a spring or digital scale, wing chord with a wing rule as the length of the nonflattened wing from the bend of the wrist to the tip of the longest primary feather, and tail length as the length from the tail base to the tip of the longest central rectrix (Ralph et al. 1993).

\section{CHAPTER 2. REFINED CONSERVATION STRATEGIES FOR GOLDEN-WINGED WARBLERS IN THE WEST VIRGINIA HIGHLANDS WITH IMPLICATIONS FOR THE BROADER AVIAN COMMUNITY.}

Table 1. Summary statistics for covariates (see Table 2 for covariate notation) used in Goldenwinged Warbler density modeling and redundancy analysis in West Virginia, 2008-2015. Summary statistics are based on site-level covariate values, derived by averaging covariate values across years for each point count location $(n=273)$, then averaging across point count locations within each site $(n=121)$.

Table 2. Descriptions, notations, and justifications for covariates in model suites evaluating the association of geospatial (model suites I, II, and III) and field-vegetation (model suite IV) covariates with Golden-winged Warbler density and early-successional forest and forestinterior priority species richness. We used covariates in each model suite in two models: one with a linear term and one with a linear and a quadratic term. Each model suite also included an intercept-only model.

Table 3. We formulated conditional multinomial maximum likelihood models of availability and perceptibility as functions of covariates using package detect (Sólymos et al. 2013). For continuous covariates (e.g., Date), we formulated models with quadratic terms (e.g., Date + Date $^{2}$ ) because we expected that detection probability may not always demonstrate a straightline pattern. We evaluated competing models using Akaike's Information Criterion (AIC, Burnham and Anderson 2002). Using a parametric bootstrap approach, we derived modelaveraged estimates of availability and perceptibility using model weights $\left(w_{\mathrm{i}}\right)$. K is the number of parameters in the model and $-2 \ln L$ is the maximum log likelihood. We presented all candidate models.

Table 4. Median fixed effect coefficients, median random effect standard deviations, and 95\% quantile confidence intervals (QCI) for plausible models (median evidence ratio $\leq 2.7$ ) in each model suite. Model suite IV had no plausible models.

Table 5. Species detected on point counts during May-June 2008-2015. For canonical correspondence analysis, we excluded species when non-flyover detections of males occurred on fewer than 10\% of sites across 2008-2015 (see “\% male occurrence" column). We also excluded Ruby-throated Hummingbird because they exhibit limited vocalizations and American Goldfinch because they are somewhat non-territorial, wide-ranging, gregarious, and breed later than most other songbirds. An " $X$ " in the appropriate column indicates if the species' position in the ordination overlapped the range of values for the constraining variable associated with greater than median Golden-winged Warbler density (1.5-km minimum 
elevation $=602-1,006 \mathrm{~m}, 100-\mathrm{m}$ minimum elevation $=540-914 \mathrm{~m}, 100-\mathrm{m}$ shrubland cover $=$ $52-100 \%)$

CHAPTER 3. MINIMALL Y-BIASED ESTIMATES OF ANNUAL SURVIVAL AND DISPERSAL FOR BREEDING VERMIVORA WARBLERS IN WEST VIRGINIA 61

Table 1. Sample sizes of Golden-winged Warbler (Vermivora chrysoptera), Blue-winged Warbler (V. cyanoptera), and hybrids (V. chyrsoptera x cyanoptera) banded in the Allegheny Mountains of West Virginia during 2008-2014 and available for resighting during 2009-2015.

Table 2. Summary statistics for survival probability and observed dispersal distance of Goldenwinged Warblers, Blue-winged Warblers, and hybrids banded and resighted in the Allegheny Mountains of West Virginia during 2008-2015. Survival probabilities were estimated with a spatial Cormack-Jolly-Seber model using after hatch year Golden-winged Warbler males from the southern study area as the baseline or reference level (s-CJS, Schaub and Royle 2014). Based on our s-CJS model, expected breeding dispersal distance was 329 m (95\% CI = 316$344 \mathrm{~m})$ and expected natal dispersal distance was $544 \mathrm{~m}(95 \% \mathrm{CI}=500-592 \mathrm{~m})$. Ages include hatch year (HY), second year (SY), after second year (ASY), and after hatch year (AHY).... 83

\section{CHAPTER 4. GOLDEN-WINGED WARBLERS MAY SELECT NESTING} TERRITORIES WITH NON-RANDOM SHRUB COMMUNITY CONFIGURATION... 90

Table 1. Model selection results for Golden-winged Warbler nest-site selection and territory selection on pastures in West Virginia during 2011-2014. Models with median $E \leq 2.7$ were plausible. We also calculated the proportion $(M)$ of subsample replicates $(\mathrm{n}=2,000)$ in which each model was considered plausible. Regression coefficients from plausible models that were considered biologically important (i.e., quantile confidence limit did not overlap zero) are bolded.

Table 2. Shrub species at Golden-winged Warbler nests $(n=122)$ and random plots $(n=122)$ within territories on pastures in West Virginia during 2011-2014 based on line-point intercept transects.

Table 3. Vegetation canopy height was taller (mean) and exhibited more variation (standard deviation) at Golden-winged Warbler nests $(n=17)$ compared to random plots $(n=17)$ within the surrounding territory measured in Pocahontas County, West Virginia during 2012. We used linear mixed models with fixed effect for plot type (nest or random), a random intercept varying among male ID $(n=10)$, and a random intercept varying among matched sets of nest and random plots nested within male ID. We considered results statistically significant at $\mathrm{a}=$ 0.05

\section{CHAPTER 5. HOW LONG DO SHRUBLAND NESTING BIRDS PERSIST ON} ABANDONED PASTURES?

Table 1. Shrubland-nesting bird species (Sauer et al. 2017) included in our species richness analysis that were detected during 10 -min, 100 -m radius point counts on pastures $(\mathrm{n}=68)$ in Monroe, Pendleton, Pocahontas, Randolph, and Tucker counties, WV during 2008-2014.... 150

Table 2. Constant or intercept-only models of the two components of detection probability: availability (i.e., time-removal model), the probability that an individual bird presents a cue and is thus available for detection, and perceptibility (i.e., distance-sampling model), the 
probability than an observer detects an individual bird given that the bird is available. Models for both species had significant intercepts, suggesting imperfect detection of males during point counts in West Virginia during 2008-2014.

151

Table 3. Summary statistics for Poisson lognormal mixed effect models of male Field Sparrow density, male Golden-winged Warbler density, and shrubland-nesting bird richness in West Virginia during 2008-2014. The Field Sparrow density model included a linear fixed effect term for years since pasture abandonment (YSA) and the Golden-winged Warbler density model and the shrubland-nesting bird richness model included linear and quadratic fixed effect terms for YSA. All models included a random intercept for pasture ID and a random slope for pasture size. We scaled YSA (range: $0-1$ ) and pasture size (range: $0-1$ ) to aid in model convergence. 152

Table 4. Summary statistics for mixed effect beta regression models of shrubland cover, herbaceous cover, and forest cover from a chronosequence of pastures in West Virginia in 2011. The herbaceous cover and forest cover models included a linear fixed effect term for years since pasture abandonment (YSA) and the shrubland cover model included a linear and quadratic fixed effect term for YSA. All models included a random slope for pasture size. We scaled YSA (range: $0-1$ ) and pasture size (range: $0-1$ ) to aid in model convergence. 153

\section{CHAPTER 6. HIGH NEST SURVIVAL DURING THE BREEDING SEASON MAY OFFSET OTHER LIMITING FACTORS FOR LOCAL POPULATIONS OF GOLDEN- WINGED WARBLERS

Table 1. Covariates $(n=35)$ and scales $(n=4)$ used in Golden-winged Warbler nest survival analysis indicated by measurement unit. Categorical covariates indicated by " $\mathrm{X}$ ”. Lack of measurement unit indicates that covariate was not used in Golden-winged Warbler nest survival analysis.

Table 2. Covariates $(n=35)$ and scales $(n=4)$ used in Golden-winged Warbler population trend modeling indicated by measurement unit. Categorical covariates indicated by " $\mathrm{X}$ ”. Lack of measurement unit indicates that covariate was not used in Golden-winged Warbler population trend analysis. 188

Table 3. Full model-selection results for daily survival rate of Golden-winged Warbler (Vermivora chrysoptera) nests from pastures in Pocahontas and Randolph counties, West Virginia during 2008-2014. We used the nest survival model of package RMark (version 2.2.4, Laake 2013) in program $\mathrm{R}$ (version 3.4.4, R Development Core Team 2018), which is an interface to program MARK (version 9.0, White and Burnham 1999), and Akaike’s Information Criterion adjusted for small sample size (AIC $\mathrm{A}_{c}$ ) for analysis of daily survival rate of nests. $\mathrm{K}$ is the number of parameters in the model, $\mathrm{AIC}_{\mathrm{c}}$ is Akaike's Information Criterion adjusted for small sample size, $\Delta \mathrm{AIC}_{\mathrm{c}}$ is the difference in $\mathrm{AIC}_{\mathrm{c}}$ values between individual models and the top model, $w_{i}$ is the model weight, and LL is the log-likelihood. Models with $\Delta \mathrm{AIC}_{\mathrm{c}} \leq 2.0$ were considered plausible.

Table 4. Beta coefficients and 95\% lower (LCL) and upper (UCL) confidence limits for covariates in best-supported $\left(\Delta \mathrm{AIC}_{\mathrm{c}} \leq 2.0\right)$ models of daily survival rate of Golden-winged Warbler (Vermivora chrysoptera) nests from pastures in Pocahontas and Randolph counties, West Virginia during 2008-2014. Bold text represents covariates that we considered biologically important because the $95 \%$ confidence interval did not overlap zero. 
Table 5. Model-selection results for Golden-winged Warbler (Vermivora chrysoptera) population trends from pastures in Pocahontas and Randolph counties, West Virginia during 2008-2014. We used package Ime4 (version 1.1-16, Bates et al. 2015) in program R (version 3.4.4, R Development Core Team 2018) to formulate Poisson lognormal mixed effect models of density fitted with Laplace estimation. Models included one linear covariate term and an interaction with years since management. The constant density model (intercept only) and a model with only years since management did not include this interaction. All models included a random intercept for pasture, a random slope for years since management, and an offset for the log of the amount of shrubland cover type per pasture. We used Akaike's Information Criterion adjusted for small sample size ( $\mathrm{AIC}_{\mathrm{c}}$ ) to select among models. $\mathrm{K}$ is the number of parameters in the model, AIC $_{c}$ is Akaike's Information Criterion adjusted for small sample size, $\Delta \mathrm{AIC}_{\mathrm{c}}$ is the difference in $\mathrm{AIC}_{\mathrm{c}}$ values between individual models and the top model, $w_{i}$ is the model weight, and LL is the log-likelihood. Models with $\Delta \mathrm{AIC}_{\mathrm{c}} \leq 2.0$ were considered plausible.

Table 6. Beta coefficients and 95\% lower (LCL) and upper (UCL) confidence limits for covariates in best-supported $\left(\Delta \mathrm{AIC}_{\mathrm{c}} \leq 2.0\right)$ models of Golden-winged Warbler (Vermivora chrysoptera) population trend from pastures in Pocahontas and Randolph counties, West Virginia during 2008-2014. Bold text represents covariates that we considered biologically important because the $95 \%$ confidence interval did not overlap zero. Note that covariates were mean-centered and scaled by dividing by their standard deviation using the scale function in the base package in program R (version 3.4.4, R Development Core Team 2018). Meancentering and scaling reportedly aids in model convergence, reduces multicollinearity and estimated standard errors, and enhances interpretability (Afshartous and Preston 2011). 193 


\section{LIST OF FIGURES}

CHAPTER 1. INTRODUCTION

Figure 1. Golden-winged Warbler breeding range and all locations from which I collected data for this dissertation. Range map data are from Roth et al. (2012). 11

Figure 2. Male Golden-winged Warbler foraging on hawthorn (Crataegus sp.). Illustration by Joni Aldinger.

Figure 3. Number of articles across all databases within Web of Science with Golden-winged Warbler in the title or keywords during 1938-2018.

Figure 4. Visual abstract of dissertation results.

\section{CHAPTER 2. REFINED CONSERVATION STRATEGIES FOR GOLDEN-WINGED WARBLERS IN THE WEST VIRGINIA HIGHLANDS WITH IMPLICATIONS FOR THE BROADER AVIAN COMMUNITY.}

Figure 1. Within the Golden-winged Warbler's contemporary breeding range in West Virginia (A; Roth et al. 2012), we surveyed sites (B, $n=121)$ with 10-min, 100-m radius avian point counts ( $\mathbf{C}, n=273$ unique point count locations, $n=1,096$ point counts) during May-June 2008-2015

Figure 2. We sampled a successional gradient ranging from (A) herbaceous to (B) shrubland to (C) young forest to (D) later successional forest vegetation communities. Vegetative conditions varied widely among point count locations $(n=273)$ at the $100-\mathrm{m}$ scale due to varied management regimes among sites $(\mathrm{n}=121)$.

Figure 3. Median marginal predicted male Golden-winged Warbler density (solid line) and 95\% quantile confidence interval (dashed lines). Predictions are based on the top density model including fixed effects for 1.5-km minimum elevation, $100-\mathrm{m}$ minimum elevation, and 100-m shrubland cover and random effects for point count location ID, site, and year (Table 4). Gray bars represent \# of point count locations sampled. See Table 2 for covariate descriptions....... 56

Figure 4. Canonical correspondence analysis results for species within the ranges of fitted covariate surface values predicted to be associated with greater than median densities of Golden-winged Warbler (Figure 5: 100-m shrubland cover $=52-100 \%, 100-\mathrm{m}$ minimum elevation = 540-914 m, 1.5-km minimum elevation = 602-1,006 m). Blue-winged Warbler (BWWA bold italics) is highlighted because the species hybridizes with Golden-winged Warbler. Darker shading represents overlapping covariate ranges. See Table 5 for species abbreviations.

Figure 5. We used AIC (Burnham and Anderson 2002) to compare among candidate Goldenwinged Warbler density models for model suites I (5-km geospatial covariates: annual dispersal scale), II (1.5-km geospatial covariates: extra-territorial movement scale), and III (100-m geospatial covariates: intra-territorial movement scale). We calculated the evidence ratio $(\mathrm{E}=\mathrm{e} 0.5 \Delta \mathrm{AIC}$, where $\triangle \mathrm{AIC}$ is the $\mathrm{AIC}$ value of the candidate model minus the minimum AIC value in the model suite) for each model in each bootstrap replicate ( $n=1,000$ replicates). $\mathrm{M}$ is the proportion of bootstrap replicates when $\mathrm{E} \leq 2.7$ (gray bars). Data labels represent median E across all bootstrap replicates. Models with median E $\leq 2.7$ (bold labels) were considered plausible. All models had random intercepts for year and for point count ID nested 
within site. Asterisks denote models not included in the model suite. See Table 2 for covariate descriptions (TWI = topographic wetness index).

Figure 6. We used AIC (Burnham and Anderson 2002) to compare among candidate Goldenwinged Warbler density models in model suite IV (field vegetation covariates: local resource utilization scale). We calculated the evidence ratio $\left(E=e^{0.5 \triangle A I C}\right.$, where $\triangle \mathrm{AIC}$ is the AIC value of the candidate model minus the minimum AIC value in the model suite) for each model in each bootstrap replicate ( $\mathrm{n}=1,000$ replicates). $M$ is the proportion of bootstrap replicates when $E \leq 2.7$ (gray bars). Data labels represent median $E$ across all bootstrap replicates. No models were considered plausible (all median $E>2.7$ ). All models had random intercepts for year and for point count ID nested within site. See Table 2 for covariate descriptions.

Figure 7. We used AIC (Burnham and Anderson 2002) to compare among candidate Goldenwinged Warbler density models in model suite $\mathrm{V}$, which featured all possible combinations of plausible models from model suites I-IV (Figures 2-3). We calculated the evidence ratio ( $E=$ $e^{0.5 \Delta A I C}$, where $\triangle \mathrm{AIC}$ is the AIC value of the candidate model minus the minimum AIC value in the model suite) for each model in each bootstrap replicate ( $n=1,000$ replicates). $M$ is the proportion of bootstrap replicates when $E \leq 2.7$ (gray bars). Data labels represent median $E$ across all bootstrap replicates. Models with median $E \leq 2.7$ (bold labels) were considered plausible. All models had random intercepts for year and for point count ID nested within site. Asterisks denote models not included in the model suite. See Table 2 for covariate descriptions.

\section{CHAPTER 3. MINIMALLY-BIASED ESTIMATES OF ANNUAL SURVIVAL AND} DISPERSAL FOR BREEDING VERMIVORA WARBLERS IN WEST VIRGINIA

Figure 1. The number of core and peripheral sites and thus the amount (ha) of shrubland cover monitored changed over time during our 2008-2015 study of Golden-winged Warbler annual survival and dispersal in the Allegheny Mountains of West Virginia.

Figure 2. Observed distances of dispersal events for Vermivora warblers by age (HY = hatch year, SY = second year, ASY = after second year) and sex in the Allegheny Mountains of West Virginia during 2008-2015. See Table 2 for summary statistics for dispersal distances.

Figure 3. We banded and resighted Vermivora warblers across two study areas in the Allegheny Mountains of West Virginia during 2008-2015. The northern study area (top) had decreasing populations of Golden-winged Warblers, while the southern study area (bottom) had relatively stable populations.

Figure 4. Histogram of years encountered ( $n=517$ warblers) and longevity (age in years, $n=$ 102 adult warblers with known age at time of banding) of Vermivora warblers in the Allegheny Mountains of West Virginia during 2008-2015. 88

Figure 5. Expected dispersal distances of Vermivora warblers in the Allegheny Mountains of West Virginia during 2008-2015 derived from our spatial Cormack-Jolly-Seber survival model. Posterior mean expected breeding dispersal (AHY) distance was 329 m (95\% confidence interval [CI] = 316-344 m) and expected natal dispersal $(\mathrm{HY})$ distance was 544 (95\% CI $=500-592 \mathrm{~m})$. The y-axis represents the density, or relative frequency, of expected dispersal distances. 
Figure 1. During 2011-2014, we collected vegetation data at Golden-winged Warbler nests (n $=122)$ and random plots $(n=122)$ within pastures $(n=15)$ in Pocahontas and Randolph counties, West Virginia. Golden-winged Warblers generally nested within shrub-dominated areas adjacent to later successional forest, as shown above in one of our pastures on the Monongahela National Forest in Pocahontas County.

Figure 2. On a subset of two cattle pastures (panel A), we obtained airborne light detection and ranging (LIDAR) data (panel B) to quantify vegetation canopy height within Golden-winged Warbler territories in West Virginia during 2012. We used LIDAR data to derive a digital elevation model (DEM, range =917-1,179 m, panel C) using ground laser returns and a digital surface model (DSM, range $=919-1,199 \mathrm{~m}$, panel D) using first laser returns. We subtracted the DEM from the DSM to derive a canopy height model (CHM, range $=0-37 \mathrm{~m}$, panel $\mathrm{E}$ ) that was used in vegetation canopy use modeling. 118

Figure 3. Golden-winged Warblers selected nest sites with higher shrub cover within $11.3 \mathrm{~m}$ compared to the surrounding territory on pastures in West Virginia during 2011-2014. We did not find evidence of selection for a particular shrub community configuration based on edge magnitude and number of runs at nest sites compared to the surrounding territory............... 119

Figure 4. During 2011-2014 in West Virginia, Golden-winged Warblers selected territories with larger edge magnitude compared to the full simulated distribution of possible shrub community configurations. Edge magnitude was the absolute value of the difference in shrub cover on either side of the center point of a transect. We assigned the maximum value of the two transects for each plot. Therefore, a value of $0 \%$ suggests a lack of edge characteristics, while a value of $100 \%$ is equivalent to complete shrub cover on one side of the transect center point and a lack of shrub cover on the opposite site of the transect center point.

Figure 5. During 2011-2014 in West Virginia, Golden-winged Warblers selected territories with fewer runs compared to the full simulated distribution of possible shrub community configurations. A "run" (range $=1-11$ ) is defined as a sequence of consecutive shrub presences or absences along a 22.6-m line-point intercept transect with 11 equally spaced points. A new run occurs whenever occurrence (present or absent) changes. We assigned the mean value of the 2 transects for each plot.

Figure 6. Golden-winged Warbler territories had more pronounced edges than would be expected given a random shrub configuration with an equivalent amount of shrub cover. Edge magnitude was the absolute value of the difference in shrub cover on either side of the center point of a transect. We assigned the maximum value of the two transects for each plot. Therefore, a value of $0 \%$ suggests a lack of edge characteristics, while a value of $100 \%$ is equivalent to complete shrub cover on one side of the transect center point and a lack of shrub cover on the opposite site of the transect center point.

Figure 7. Golden-winged Warblers territories had a more clumped rather than dispersed or uniform shrub configuration than would be expected given a random shrub configuration with an equivalent amount of shrub cover. A "run" (range =1-11) is defined as a sequence of consecutive shrub presences or absences along a 22.6-m line-point intercept transect with 11 equally spaced points. A new run occurs whenever occurrence (present or absent) changes. We assigned the mean value of the 2 transects for each plot. 
Figure 8. Vegetation canopy height (m) at Golden-winged Warbler nest sites was significantly taller and more variable compared to random plots. Specifically, nests had less short vegetation $(\leq 0.5 \mathrm{~m}$ ), such as grasses, forbs, blackberry (Rubus spp.), and seedlings, in the canopy and more trees $>5 \mathrm{~m}$ tall.

\section{CHAPTER 5. HOW LONG DO SHRUBLAND NESTING BIRDS PERSIST ON ABANDONED PASTURES?}

Figure 1. Examples from our 62-year chronosequence of abandoned pastures in West Virginia during 2008-2014. $A=0$ years since abandonment, $B=7$ years, $C=17$ years, $D=22$ years, $E$ $=39$ years, $\mathrm{F}=62$ years. 154

Figure 2. Predicted mean male density (solid black line) of Field Sparrow (top panel) and Golden-winged Warbler (bottom panel) adjusted for detection probability based on avian point counts from a chronosequence (range $0-62$ years) of pastures $(n=68)$ in West Virginia during 2008-2014. Dotted lines represent 95\% confidence intervals. Gray circles represent raw observed densities (count of males per 3.14 ha) and darker shades represent overlapping circles. Note different y-axis scales.

Figure 3. Predicted mean cover (solid black line) of herbaceous (top panel), shrubland (middle panel), and forest (bottom panel) as a function of years since pasture abandonment (range $=0$ 59 years) based on land cover on individual pastures $(n=68)$ in West Virginia in 2011. Dotted lines represent the 95\% confidence interval. Gray circles represent observed values for individual pastures and darker shades representing overlapping circles. 156

\section{CHAPTER 6. HIGH NEST SURVIVAL DURING THE BREEDING SEASON MAY OFFSET OTHER LIMITING FACTORS FOR LOCAL POPULATIONS OF GOLDEN- WINGED WARBLERS}

Figure 1. Shrubland cover type on our pastures in West Virginia during 2008-2014 was maintained with cattle grazing (panel A) and mechanical vegetation management consisting of hand-cutting shrubs and trees with chainsaws and brush hogging with a compact track loader or tractor with brush hog attachment (panel B). One abandoned pasture was neither grazed nor mechanically managed. Mechanical vegetation management occurred during Fall 2008 on pastures in Randolph County and during Fall 2009 on our pastures in Pocahontas County. Areas targeted for management were characterized by a uniform closed-canopy thicket of shrubs, usually hawthorn (Crataegus spp), autumn olive (Elaeagnus umbellata), and multiflora rose (Rosa multiflora), where (1) Golden-winged Warbler nest-site characteristics were disappearing to vegetative succession, (2) cattle forage was absent due to shading, and (3) shrubs formed a physical barrier to cattle. Note dense patch of shrubs left of center pretreatment (2007) in panel C and post-treatment (2009) in panel D.

Figure 2. Photographic time series of mechanical vegetation management at the same location on a pasture in Randolph County immediately following management (panel A, 12 September 2008), 2 years post-management (panel B, 11 August 2010), 4 years post management (panel C, 2 May 2012), and 5 years post-management (panel D, 11 May 2013). 195

Figure 3. Among candidate models of Golden-winged Warbler nest daily survival date (DSR) from nests in Pocahontas and Randolph counties, West Virginia during 2008-2014, 13 models had $\Delta \mathrm{AIC}_{\mathrm{c}} \leq 2.0$ and were considered plausible (Burnham and Anderson 2002). Nest DSR was higher on pastures in Pocahontas County $($ mean $=0.973,95 \%$ confidence interval $(\mathrm{CI})=$ 
0.962-0.981) than on pastures in Randolph County (mean $=0.949,95 \%$ CI $=0.926-0.965$ ), positively associated with amount of pasture-scale shrubland cover type, proportion of territory-scale grazed (GMm) shrubland cover type, and nest- and territory-scale elevation, and negatively associated with proportions of territory-scale ungrazed and unmanaged (gm), unmanaged (Ggm), and ungrazed (gMm) shrubland cover types. Solid line represents mean nest DSR and dashed lines represent 95\% CIs.

Figure 4. Our only plausible model $\left(\Delta \mathrm{AIC}_{\mathrm{c}} \leq 2.0\right.$, Burnham and Anderson 2002) of Goldenwinged Warbler density included an interaction between nest daily survival rate (DSR) and years since management. Golden-winged Warbler density was negatively correlated with nest DSR and years since management and these two covariates interacted. At the minimum value for nest DSR (0.934, gray line), Golden-winged Warbler density decreased by 50\% per year, while at the maximum value for nest DSR (0.978, black line), Golden-winged Warbler density decreased by only 1\% per year. Dashed lines represent $95 \%$ confidence limits. 


\section{PART 1. GOLDEN-WINGED WARBLER INTRODUCTION CHAPTER 1. INTRODUCTION}

Forest disturbance regimes across eastern North America have changed for millennia, particularly in response to variation in human settlement patterns and resource utilization (Lorimer 2001). Local populations of animals that depend on habitats maintained by some form of disturbance have therefore fluctuated because disturbances occur with varying frequency in time and space and the resulting vegetation communities tend to be ephemeral (Litvaitis 1993, Brawn et al. 2001). Since the late nineteenth century through today however, trends for the amount and frequency of disturbance and for disturbance-dependent animal populations have been predominantly unidirectional. In the late nineteenth century, the extent of shrubland and young forest vegetation communities reached historic highs across much of eastern North America due to extensive forest harvesting, fires, and agricultural abandonment (Lorimer 2001). Today the abundance of shrubland and young forest vegetation communities is historically low due to suppression of disturbances and subsequent forest maturation (Shifley and Thompson 2011, King and Schlossberg 2014). During this time, many disturbance-dependent animals have experienced widespread and persistent population decreases, with some species now even listed under the federal Endangered Species Act or extinct (Hill and Hagan 1991, Hunter et al. 2001, Litvaitis 2001, Sauer et al. 2017).

Population regulation for animals often is not as simple as a lack of a certain vegetation seral stage; there are varying degrees of complexity with regards to the numbers of and interactions among limiting factors (Wilcove et al. 1998). For example, New England cottontail (Sylvilagus transitionalis) populations, which are obligate users of shrubland and young forest cover types throughout their annual cycle and exhibit limited dispersal, respond by increasing in abundance following disturbance because availability of quality shrubland and young forest cover acts strongly as a chief limiting factor (Litvaitis and Warren 2016). American Redstart (Setophaga ruticilla) populations on the other hand, are migratory, highly mobile, and although they prefer nesting in disturbed vegetation communities, depend on multiple forest ages and types within and among stages of their life cycle (Hunt 1996, Sherry et al. 2016). Therefore, American Restart populations are more likely to be limited by multiple competing factors, which could even have carry-over effects into later times or places (Sillett and Holmes 2002, Norris et al. 2004). For species that have complex life cycles affected by potentially numerous limiting 
factors, research into these limiting factors and corresponding conservation actions intended to bolster populations are vitally important for long term population viability. Among imperiled disturbance-dependent species, few have a life cycle quite as complex or present a conservation conundrum quite as complicated as the Golden-winged Warbler (Vermivora chrysoptera). It is for that reason that this dissertation research was undertaken.

The Golden-winged Warbler is a small (Table 1) migratory songbird that breeds in eastern North America (Figure 1) and winters in Central and northern South America (Confer et al. 2011, Rosenberg et al. 2016). First described by Edwards (1760), this member of Parulidae has a striking combination of gray overall body plumage, black eye and throat patches, and gold crown and wing bars (Figure 2). Golden-winged Warblers require dynamic forest landscapes for breeding, characterized by a majority of later successional forest and scattered patches of shrublands and young forests resulting from various types of disturbance (Crawford et al. 2016). In the Appalachian Mountains segment of their breeding population, they occur at elevations $>500 \mathrm{~m}$ (Crawford et al. 2016). At finer scales, Golden-winged Warblers defend breeding territories that encompass a mix of herbaceous vegetation, shrubs, saplings, scattered canopy trees, and later successional forest edges (Confer et al. 2011). The species fledges a single brood annually from a ground nest often placed at the transition between dense shrub cover and small herbaceous openings (Aldinger and Wood 2014). Golden-winged Warblers selectively forage on and use breeding habitat containing higher proportions of caterpillar-laden shrubs and trees such as black locust (Robinia pseudoacacia), pin cherry (Prunus pensylvanica), white oak (Quercus $a l b a$ ), and blackberry (Rubus spp.), upon which they predominantly employ a probing technique to pry open curled leaves (Bellush et al. 2016).

Golden-winged Warbler populations have had a similar fate as many other disturbancedependent species. For as long as we have had monitoring data, researchers have noted an overall population decrease (Massachusetts 1937-1989: -1.4\% per year, Hill and Hagan 1991; West Virginia 1966-2015: -8.6\% per year, Sauer et al. 2017; range-wide 1966-2015: -2.3\% per year, Sauer et al. 2017). Forest succession (Gill 1980), land-use change (Confer and Knapp 1979), lack of natural and anthropogenic disturbances (Hunter et al. 2001), patch- and landscapelevel vegetation structure and composition (Peterson et al. 2016), Brown-headed Cowbird (Molothrus ater) brood parasitism (Confer et al. 2003), topographic position (Confer et al. 2010), competition (Confer et al. 2003) and hybridization (Vallender et al. 2009) with Blue-winged 
Warblers (Vermivora cyanoptera), and non-breeding season survival (Hobson et al. 2016) each represent competing hypotheses posited to explain observed population trends (Rohrbaugh et al. 2016). No single threat or combination of these threats has definitively explained plummeting numbers of Golden-winged Warblers. As such, questions remain about the effectiveness of proposed conservation strategies targeting one or a couple of these threats as opposed to a more comprehensive approach (Martin et al. 2007, Streby et al. 2018). Still, the many research projects and publications centered around Golden-winged Warblers are drawing us closer to a strong explanation of the species' trajectory.

When I started this project as a master's student in January 2008, the Golden-winged Warbler was a relatively well-studied studied Neotropical migratory passerine (Figure 3; see http://gwwa.org/bibliography.html for literature through 2009). And yet, since 2008 our knowledge of the species may have increased more than any other decade. To illustrate a point about the great influx of knowledge on Golden-winged Warblers during 2008-2018, I have intentionally told somewhat of an incomplete story in the previous two paragraphs. Below I highlight some major discoveries during the last ten years that help to place this dissertation into context and that illustrate how my dissertation process was constantly evolving.

In 2008, the Vermivora genus contained 8 extant species (American Ornithologists' Union 1998), Blue-winged Warblers possibly were genetically swamping their Golden-winged counterparts (Gill 1997, Dabrowski et al. 2005), and we were just scratching the surface of the extent of genetic similarity between Golden-winged and Blue-winged Warblers (Vallender et al. 2007). Studies of Golden-winged Warbler response to management were observational rather than experimental (Martin et al. 2007, Kubel and Yahner 2008). Later successional forest was hardly more than a territorial boundary (Ficken and Ficken 1967, Confer and Knapp 1981) and fledgling survival and ecology, non-breeding distribution and habitat, and migratory connectivity were virtually unknown except for anecdotal evidence (Ridgely and Tudor 1989, Stiles and Skutch 1989; but see Will 1986). By 2018, the Vermivora genus through reclassification contained just 2 extant species (V. chrysoptera and V. cyanoptera, Lovette et al. 2010), one of which had been renamed (V. pinus to V. cyanoptera, Olson and Reveal 2009). Genetic introgression among populations of Golden-winged and Blue-winged Warblers was almost unequivocally bidirectional (Vallender et al. 2009), which now seems inconsequential since the two species share $99.97 \%$ of their genomes (Toews et al. 2016). Studies of Golden-winged 
Warbler response to management evolved to include experimental manipulation of habitat characteristics as part of the study design (Bakermans et al. 2015, McNeil et al. 2017). Later successional forests not only proved important in predicting occurrence and abundance of Golden-winged Warblers at a landscape scale (Thogmartin 2010, Crawford et al. 2016), but we also learned their importance for the post-fledging period and in some cases even for nesting (Streby et al. 2016a). Finally, due in large part to stable isotopes in feathers and miniature tracking devices, we now have a basic understanding of the non-breeding range, habitat associations, and migratory connectivity of Golden-winged Warblers (Chandler and King 2011, Hobson et al. 2016, Kramer et al. 2018). A recent discovery using light-level geolocators on adult Golden-winged Warblers, Blue-winged Warblers, and hybrids indicated that survival during the non-breeding season may be a primary driver of population trends for Golden-winged Warblers in the Appalachian Mountains (Kramer et al. 2018). Each of these findings has important implications for a dissertation with an initial premise of promoting long-term population persistence of Golden-winged Warblers through study of breeding season ecology and management response.

The research contained in this dissertation centers on the breeding season ecology and management of Golden-winged Warblers in the Allegheny Mountains of West Virginia with implications for other disturbance-dependent avian species. I organized this dissertation into 3 parts that follow a progression of accumulating knowledge on the species. Part 1 includes chapter 1 and serves as a preface that provides a brief introduction and justification for the research, places the dissertation into the context of ongoing Golden-winged Warbler research, and outlines the dissertation content. Chapter 1 also includes a visual summary of the dissertation results (Figure 4). Part 2 includes chapters 2-4, which focused on Golden-winged Warbler ecology with the overall objective of filling knowledge gaps for the species to enhance conservation efforts and inform future research. Chapter 2 has been published in the journal Condor and focused on patterns of Golden-winged Warbler abundance and overall avian community structure across a large part of the species’ range in West Virginia (Aldinger et al. 2017). Chapter 3 focused on between-year survival and dispersal of juvenile and adult Vermivora warblers using a spatial mark-recapture method that allows estimation of true rather than apparent survival. Chapter 4 focused on the spatial configuration of shrubs within Goldenwinged Warbler breeding territories using a combination of field-measured and light detection 
and ranging (LIDAR) vegetation data. Part 3 includes chapters 5-6, which focused on Goldenwinged Warbler response to habitat management. Chapter 5 focused on persistence of breeding Golden-winged Warblers and other disturbance-dependent bird species on pastures with varying amounts of time since abandonment and consequently varying stages of vegetative succession. Finally, chapter 6 focused on Golden-winged Warbler population trends in response to habitat management on pastures. This dissertation research also has been part of 6 multi-state, multiorganization collaborative efforts, including the Golden-winged Warbler Atlas Project (Rosenberg et al. 2016), the Golden-winged Warbler range-wide conservation plan (Roth et al. 2012), a USDA Natural Resources Conservation Service Conservation Effects Assessment Project (Aldinger et al. 2015), an entire book on Golden-winged Warbler ecology, conservation, and habitat management (Streby et al. 2016), a range-wide atlas of genetics (Toews et al. 2016), and the Vermivora migration project (Kramer et al. 2018). The results from this dissertation (Figure 4) and the multiple collaborative efforts of which it was a part add to a still-rapidlygrowing body of research on the imperiled Golden-winged Warbler that we hope will be used to ensure the species' long-term viability and form a model for conservation of other disturbancedependent animals.

\section{LITERATURE CITED}

Aldinger, K. R., M. H. Bakermans, J. L. Larkin, J. Lehman, D. J. McNeil, A. Tisdale, D. A. Buehler, P. B. Wood, C. G. Smalling, L. Siefferman, T. Fearer. 2015. Monitoring and evaluating Golden-winged Warbler use of breeding habitat created by Natural Resources Conservation Service practices. Conservation Effects Assessment Program Final Report, USDA Natural Resources Conservation Service.

Aldinger, K. R., and P. B. Wood. 2014. Reproductive success and habitat characteristics of Golden-winged Warblers in high-elevation pasturelands. Wilson Journal of Ornithology 126:279-287.

Aldinger, K. R., P. B. Wood, and C. M. Johnson. 2017. Refined conservation strategies for Golden-winged Warblers in the West Virginia highlands with implications for the broader avian community. Condor 119:762-786.

American Ornithologists’ Union. 1998. Check-list of North American Birds, 7th ed. American Ornithologists’ Union, Washington, D.C., USA.

Bakermans, M. H., C. L. Ziegler, and J. L. Larkin. 2015. American Woodcock and Goldenwinged Warbler abundance and associated vegetation in managed habitats. 22:690-703.

Bellush, E. C., J. Duchamp, J. L. Confer, and J. L. Larkin. 2016. Influence of plant species composition on Golden-winged Warbler foraging ecology in north-central Pennsylvania. 
In Golden-winged Warbler Ecology, Conservation, and Habitat Management (H. M. Streby, D. E. Andersen, and D. A. Buehler, Editors). Studies in Avian Biology 49:95108.

Brawn, J. D., S. K. Robinson, and F. R. Thompson III. 2001. The role of disturbance in the ecology and conservation of birds. Annual Review of Ecology and Systematics 32:251276.

Chandler, R. B., and D. I. King. 2011. Habitat quality and habitat selection of Golden-winged Warblers in Costa Rica: an application of hierarchical models for open populations. Journal of Applied Ecology 48:1038-1047.

Confer, J. L., K. W. Barnes, and E. C. Alvey. 2010. Golden- and Blue-winged warblers: distribution, nesting success, and genetic differences in two habitats. Wilson Journal of Ornithology 122:273-278.

Confer, J. L., P. Hartman, and A. Roth. 2011. Golden-winged Warbler (Vermivora chrysoptera). In Birds of North America Online (A. Poole, Editor). Cornell Laboratory of Ornithology, Ithaca, NY, USA. https://birdsna.org/Species-Account/bna/species/gowwar.

Confer, J. L., J. L. Larkin, and P. E. Allen. 2003. Effects of vegetation, interspecific competition, and brood parasitism on Golden-winged Warbler (Vermivora chrysoptera) nesting success. Auk 120:138-144.

Confer, J. L., and K. Knapp. 1981. Golden-winged Warblers and Blue-winged Warblers: the relative success of a habitat specialist and a generalist. Auk 98:108-114.

Crawford, D. L., R. W. Rohrbaugh, A. M. Roth, J. D. Lowe, S. B. Swarthout, and K. V. Rosenberg. 2016. Landscape-scale habitat and climate correlates of breeding Goldenwinged and Blue-winged warblers. In Golden-winged Warbler Ecology, Conservation, and Habitat Management (H. M. Streby, D. E. Andersen, and D. A. Buehler, Editors). Studies in Avian Biology 49:41-66.

Dabrowski, A., R. Fraser, J. L. Confer, and I. J. Lovette. 2005. Geographic variability in mitochondrial introgression among hybridizing populations of Golden-winged (Vermivora chrysoptera) and Blue-winged (V. pinus) warblers. Conservation Genetics 6:843-853.

Edwards, G. 1760. Gleanings of natural history, Vol. 2. Royal College of Physicians, London.

Ficken, M. S., and R. W. Ficken. 1967. Singing behaviour of Blue-winged and Golden-winged warblers and their hybrids. Behaviour 28:149-181.

Gill, F. B. 1980. Historical aspects of hybridization between Blue-winged and Golden-winged warblers. Auk 97:1-18.

Gill, F. B. 1997. Local cytonuclear extinction of the Golden-winged Warbler. Evolution 51:519525.

Hill, N. P., and J. M. Hagan III. 1991. Population trends of some northeastern North American landbirds: a half-century of data. Wilson Bulletin 103:165-182.

Hobson, K. A., S. L. Van Wilgenburg, A. M. Roth, R. E. Bennett, N. J. Bayly, L. ChavarríaDuriaux, G. J. Colorado, P. Elizondo, C. J. Rengifo, and J. D. Ritterson. 2016. Golden- 
winged Warbler migratory connectivity derived from stable isotopes. In Golden-winged Warbler Ecology, Conservation, and Habitat Management (H. M. Streby, D. E. Andersen, and D. A. Buehler, Editors). Studies in Avian Biology 49:193-203.

Hunt, P. D. 1996. Habitat selection by American Redstarts along a successional gradient in northern hardwoods forest: evaluation of habitat quality. Auk 113:875-888.

Hunter, W. C., D. A. Buehler, R. A. Canterbury, J. L. Confer, and P. B. Hamel. 2001. Conservation of disturbance-dependent birds in eastern North America. Wildlife Society Bulletin 29:440-455.

King, D. I., and S. Schlossberg. 2014. Synthesis of the conservation value of the early-succession stage in forests of eastern North America. Forest Ecology and Management 324:186-195.

Kubel, J. E., and R. H. Yahner. 2008. Quality of anthropogenic habitats for Golden-winged Warblers in central Pennsylvania. Wilson Journal of Ornithology 120:801-812.

Kramer, G. R., D. E. Andersen, D. A. Buehler, P. B. Wood, S. M. Peterson, J. A. Lehman, K. R. Aldinger, L. P. Bulluck, S. Harding, J. A. Jones, J. P. Loegering, C. Smalling, R. Vallender, and H. M. Streby. 2018. Population trends in Vermivora warblers are linked to strong migratory connectivity. Proceedings of the National Academy of Sciences of the United States of America DOI: 10.1073/pnas.1718985115.

Litvaitis, J. A. 1993. Response of early successional vertebrates to historic changes in land use. Conservation Biology 7:866-873.

Litvaitis, J. A. 2001. Importance of early successional habitats to mammals in eastern forests. Wildlife Society Bulletin 29:466-473.

Litvaitis, J. A., and A. Warren. 2016. Final report for habitat monitoring and evaluation of Working Lands for Wildlife: New England cottontails. Department of Natural Resources and the Environment, University of New Hampshire, Durham, NH, USA.

Lorimer, C. G. 2001. Historical and ecological roles of disturbance in eastern North American forests: 9,000 years of change. Wildlife Society Bulletin 29:425-439.

Lovette, I. J., J. L. Pérez-Emán, J. P. Sullivan, R. C. Banks, I. Fiorentino, S. Córdoba-Córdoba, M. Echeverry-Galvis, F. K. Barker, K. J. Burns, J. Klicka, S. M. Lanyon, and E. Bermingham. 2010. A comprehensive multilocus phylogeny for the wood-warblers and a revised classification of the Parulidae (Aves). Molecular Phylogenetics and Evolution 57:753-770.

Martin, T. G., I. Chadés, P. Arcese, P. P. Marra, H. P. Possingham, and D. R. Norris. 2007. Optimal conservation of migratory species. PLoS ONE 2:e751.

Martin, K. J., R. S. Lutz, and M. Worland. 2007. Golden-winged Warbler habitat use and abundance in northern Wisconsin. Wilson Journal of Ornithology 119:523-532.

McNeil, D. J., K. R. Aldinger, M. H. Bakermans, J. A. Lehman, A. C. Tisdale, J. A. Jones, P. B. Wood, D. A. Buehler, C. G. Smalling, L. Siefferman, and J. L. Larkin. 2017. An evaluation and comparison of conservation guidelines for an at-risk migratory songbird. Global Ecology and Conservation 9:90-103. 
Norris, R. D., P. P. Marra, T. K. Keyser, T. W. Sherry, and L. M. Ratcliffe. 2004. Tropical winter habitat limits reproductive success on the temperate breeding grounds in a migratory bird. Proceedings of the Royal Society of London, Series B 271:59-64.

Olson, S. L., and J. L. Reveal. 2009. Nomenclatural history and a new name for the Blue-winged Warbler (Aves: Parulidae). Wilson Journal of Ornithology 121:618-620.

Peterson, S. M., H. M. Streby, and D. E. Andersen. 2016. Spatially explicit models of full-season productivity and implications for landscape management of Golden-winged Warblers in the western Great Lakes Region. In Golden-winged Warbler Ecology, Conservation, and Habitat Management (H. M. Streby, D. E. Andersen, and D. A. Buehler, Editors). Studies in Avian Biology 49:141-160.

Ralph, C. J., G. R. Geupel, P. Pyle, T. E. Martin, and D. F. DeSante. 1993. Field methods for monitoring landbirds. U.S. Department of Agriculture Forest Service General Technical Report PSW-144, Fresno, CA, USA.

Ridgely, R. S. and G. Tudor. 1989. The birds of South America, Vol. 1: the oscine passerines. University of Texas Press, Austin, TX, USA.

Rohrbaugh, R. W., D. A. Buehler, S. B. Swarthout, D. I. King, J. L. Larkin, K. V. Rosenberg, A. M. Roth, R. Vallender, and T. Will. 2016. Conservation perspectives: review of new science and primary threats to Golden-winged Warblers. In Golden-winged Warbler Ecology, Conservation, and Habitat Management (H. M. Streby, D. E. Andersen, and D. A. Buehler, Editors). Studies in Avian Biology 49:207-215.

Rosenberg, K. V., T. Will, D. A. Buehler, S. B. Swarthout, W. E. Thogmartin, R. E. Bennett, and R. B. Chandler. 2016. Dynamic distributions and population declines of Golden-winged Warblers. In Golden-winged Warbler Ecology, Conservation, and Habitat Management (H. M. Streby, D. E. Andersen, and D. A. Buehler, Editors). Studies in Avian Biology 49:3-28.

Roth, A. M., R. W. Rohrbaugh, K. R. Aldinger, M. H. Bakermans, S. Barker Swarthout, D. A. Buehler, J. L. Confer, D. Crawford, C. Friis, R. M. Fowlds, J. L. Larkin, J. Loegering, J. D. Lowe, M. Piorkowski, K. V. Rosenberg, C. Smalling, T. M. Terhune, R. Vallender, T. Will, and P. B. Wood. 2012. Golden-winged Warbler breeding season conservation plan. In Golden-winged Warbler Status Review and Conservation Plan (A. M. Roth, R. W. Rohrbaugh, T. Will, and D. A. Buehler, Editors). www.gwwa.org/plan.

Sauer, J. R., D. K. Niven, J. E. Hines, D. J. Ziolkowski, Jr, K. L. Pardieck, J. E. Fallon, and W. A. Link. 2017. The North American Breeding Bird Survey, Results and Analysis 1966 2015. Version 2.07.2017 USGS Patuxent Wildlife Research Center, Laurel, MD, USA.

Sherry, T. W., R. T. Holmes, P. Pyle, and M. A. Patten. 2016. American Redstart (Setophaga ruticilla). In Birds of North America Online (A. Poole, Editor). Cornell Laboratory of Ornithology, Ithaca, NY, USA. https://birdsna.org/Species-Account/bna/species/amered.

Shifley, S.R., Thompson III, F.R., 2011. Spatial and temporal patterns in the amount of young forests and implications for biodiversity. In Ecology and Management of Early Successional Habitats in the Central Hardwood Region (C. H. Greenberg, B. Collins, and F. R. Thompson III, Editors). Springer, New York, NY, USA, pp. 73-96. 
Sillett, T. S., and R. T. Holmes. 2002. Variation in survivorship of a migratory songbird throughout its annual cycle. Journal of Animal Ecology 71:296-308.

Stiles, F. G., and A. Skutch. 1989. A Guide to the Birds of Costa Rica. Cornell University Press, Ithaca, NY, USA.

Streby, H. M., G. R. Kramer, S. M. Peterson, and D. E. Andersen. 2018. Evaluating outcomes of management targeting the recovery of a migratory songbird of conservation concern. PeerJ 6:e4319; DOI 10.7717/peerj.4319.

Streby, H. M., D. E. Andersen, and D. A. Buehler (Editors). 2016a. Golden-winged Warbler Ecology, Conservation, and Habitat Management. Studies in Avian Biology 49.

Streby, H. M., S. M. Peterson, and D. E. Andersen. 2016b. Survival and habitat use of fledgling Golden-winged Warblers in the western Great Lakes Region. In Golden-winged Warbler Ecology, Conservation, and Habitat Management (H. M. Streby, D. E. Andersen, and D. A. Buehler, Editors). Studies in Avian Biology 49:127-140.

Thogmartin, W. E. 2010. Modeling and mapping Golden-winged Warbler abundance to improve regional conservation strategies. Avian Conservation and Ecology 5:12.

Toews, D. P. L., S. A. Taylor, R. Vallender, A. Brelsford, B. G. Butcher, P. W. Messer, and I. J. Lovette. 2016. Plumage genes and little else distinguish the genomes of hybridizing warblers. Current Biology 26:2313-2318.

Vallender, R., R. J. Robertson, V. L. Friesen, and I. J. Lovette. 2007. Complex hybridization dynamics between Golden-winged and Blue-winged warblers (Vermivora chrysoptera and Vermivora pinus) revealed by AFLP, microsatellite, intron and mtDNA markers. Molecular Ecology 16:2017-2029.

Vallender, R., S. L. Van Wilgenburg, L. P. Bulluck, A. Roth, R. Canterbury, J. L. Larkin, R. M. Fowlds, and I. J. Lovette. 2009. Extensive rangewide mitochondrial introgression indicates substantial cryptic hybridization in the Golden-winged Warbler (Vermivora chrysoptera). Avian Conservation and Ecology 4:4.

Wilcove, D. S., D. Rothstein, J. Dubow, A. Phillips, and E. Losos. 1998. Quantifying threats to imperiled species in the United States. BioScience 48:607-615.

Will, T. C. 1986. The behavioral ecology of species replacements: Blue-winged and Goldenwinged warblers in Michigan. Ph.D. dissertation, University of Michigan, Ann Arbor, MI, USA. 


\section{TABLES}

Table 1. Morphology of adult male and female Golden-winged Warblers captured at breeding sites with mist-nets during 27 April-27 June 2008-2016 in West Virginia. We measured body weight with a spring or digital scale, wing chord with a wing rule as the length of the nonflattened wing from the bend of the wrist to the tip of the longest primary feather, and tail length as the length from the tail base to the tip of the longest central rectrix (Ralph et al. 1993).

\begin{tabular}{lcc}
\hline Measurement & Male $^{\dagger}$ & Female $^{\dagger}$ \\
\hline Body weight (g) & $9.1 \pm 0.5(167)$ & $9.3 \pm 0.1(56)$ \\
Wing chord (mm) & $62.8 \pm 0.1(155)$ & $59.1 \pm 0.3(55)$ \\
Tail length (mm) & $47.3 \pm 0.2(155)$ & $45.2 \pm 0.3(55)$
\end{tabular}

${ }^{\dagger}$ Mean \pm standard deviation (n) 


\section{FIGURES}

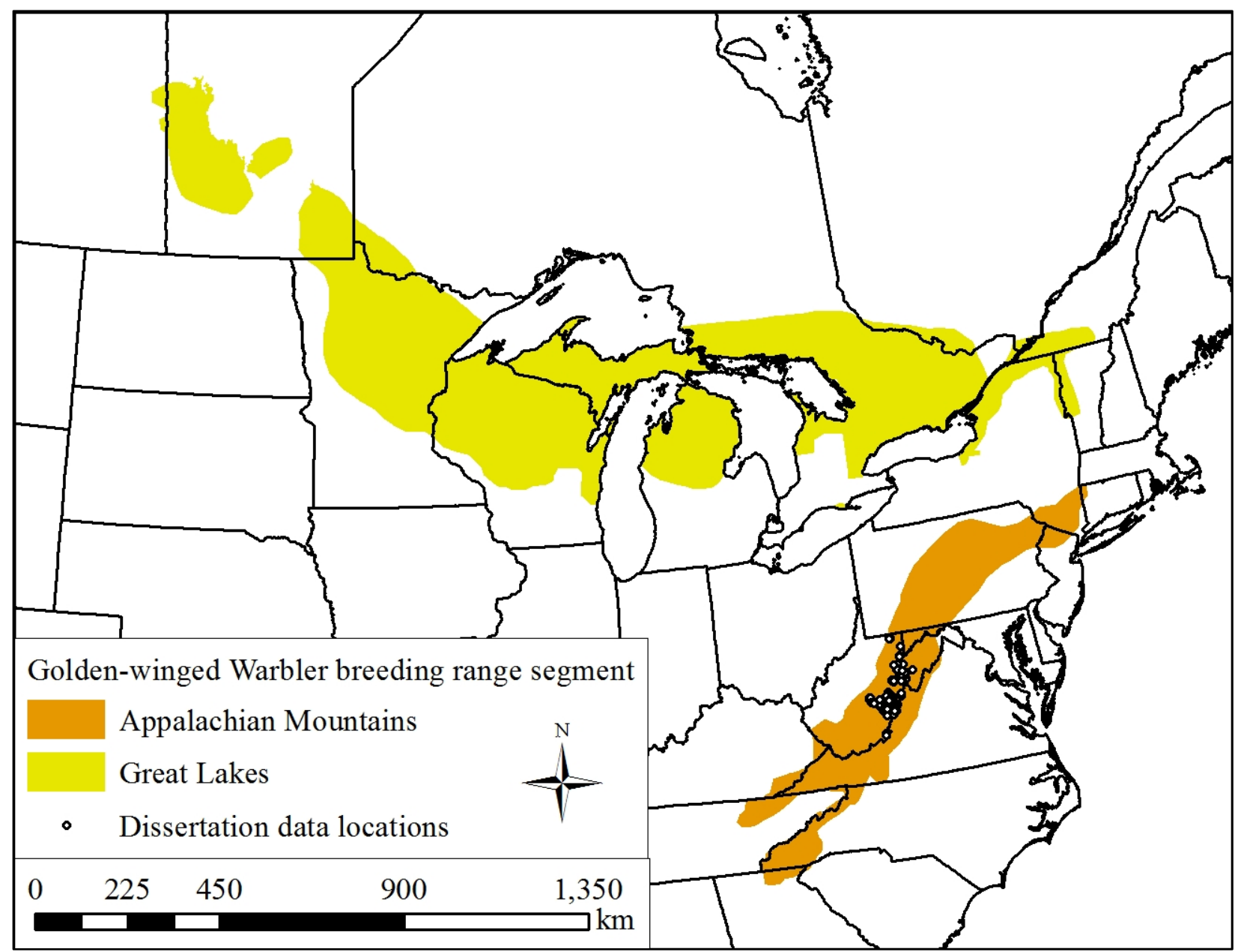

Figure 1. Golden-winged Warbler breeding range and all locations from which I collected data for this dissertation. Range map data are from Roth et al. (2012). 


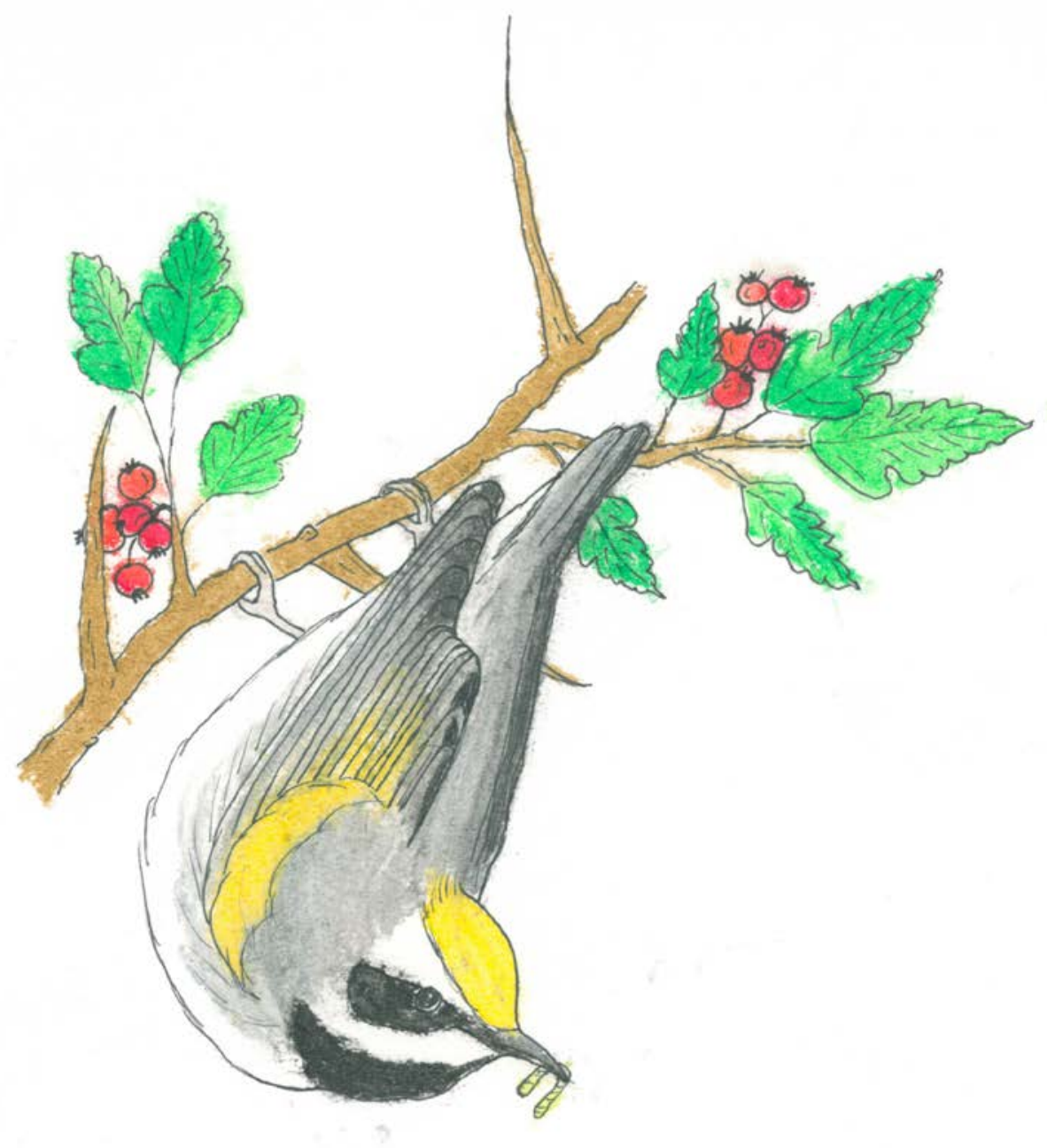

Gellaing

Figure 2. Male Golden-winged Warbler foraging on hawthorn (Crataegus sp.). Illustration by Joni Aldinger. 


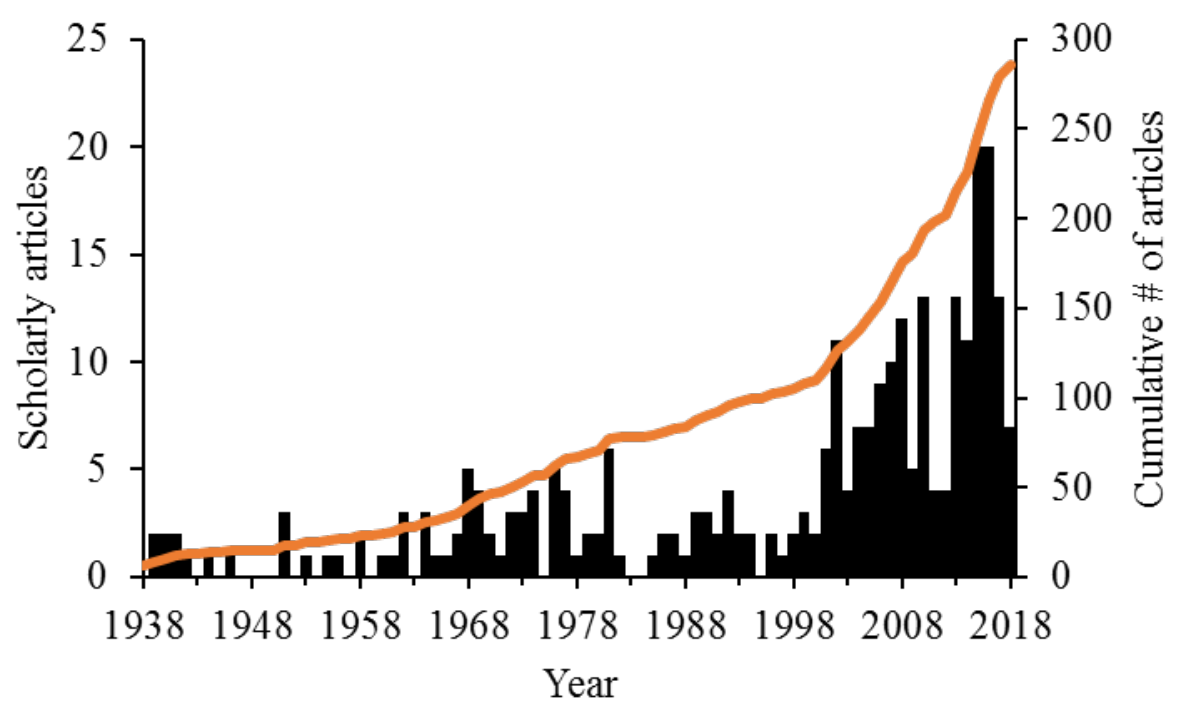

Figure 3. Number of articles across all databases within Web of Science with Golden-winged Warbler in the title or keywords during 1938-2018. 


\section{PART 2. GOLDEN-WINGED WARBLER ECOLOGY}

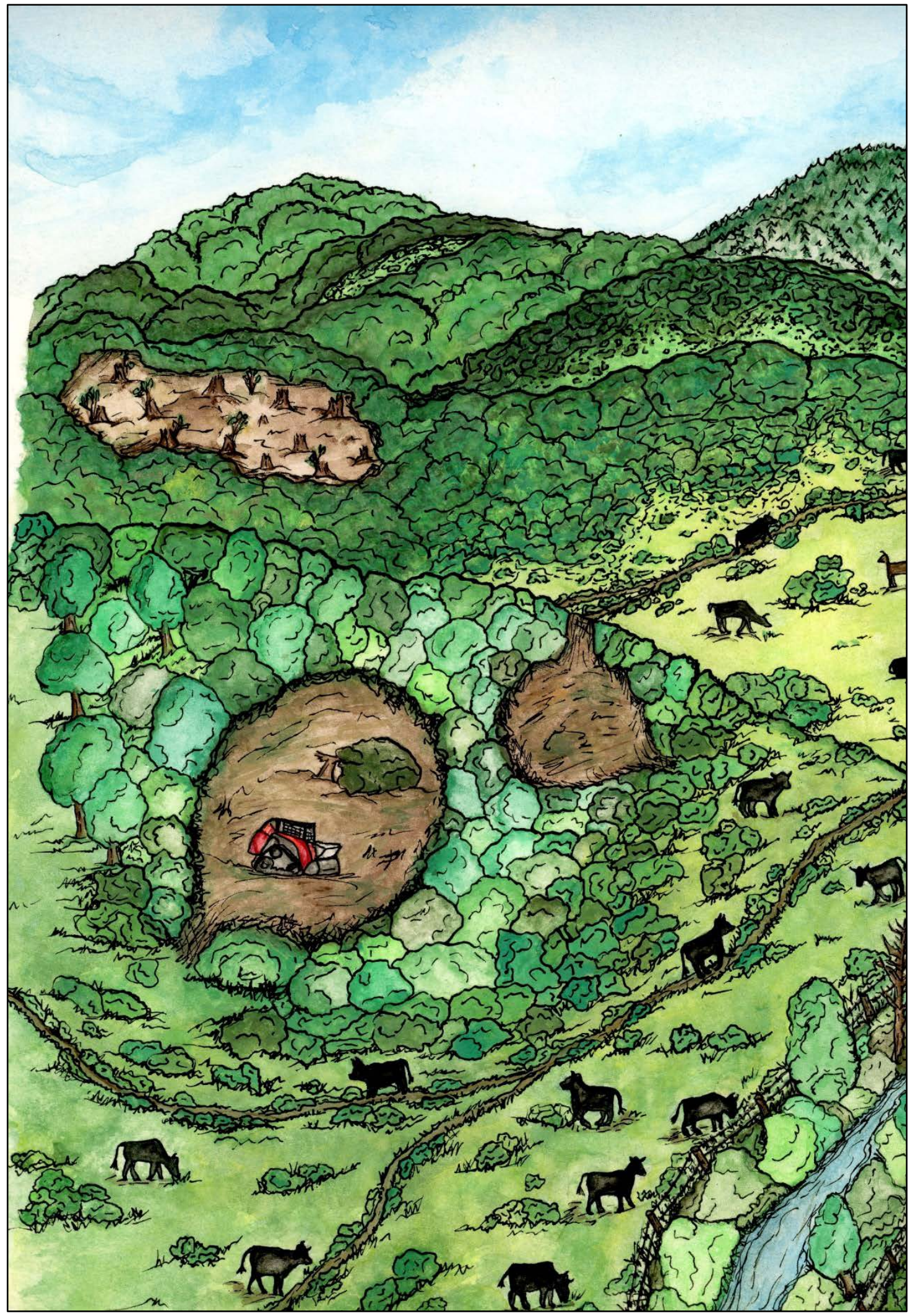




\section{CHAPTER 2. REFINED CONSERVATION STRATEGIES FOR GOLDEN-WINGED WARBLERS IN THE WEST VIRGINIA HIGHLANDS WITH IMPLICATIONS FOR THE BROADER AVIAN COMMUNITY}

\section{Chapter 2 was published in the peer-reviewed journal Condor: Ornithological Applications.}

Citation:

Aldinger, K. R., P. B. Wood, and C. M. Johnson. 2017. Refined conservation strategies for Golden-winged Warblers in the West Virginia highlands with implications for the broader avian community. Condor 119:762-786.

\section{ABSTRACT}

Golden-winged Warbler populations in the Appalachian Mountains region are imperiled, warranting species-specific conservation. However, management for Golden-winged Warblers can affect both early successional species and forest species, many of which are also declining in the region. We conducted point counts at sites representing a range of successional stages within the Golden-winged Warbler's breeding range in West Virginia during 2008-2015. We identified plausible models of Golden-winged Warbler density using covariates at 4 spatial scales representing annual dispersal (5-km radius), extra-territorial movement (1.5-km radius), intraterritorial movement (100-m radius), and local resource utilization (11.3-m radius). Goldenwinged Warbler density peaked at an intermediate elevation at the $1.5-\mathrm{km}$ radius scale, but was negatively associated with 100 -m radius minimum elevation. Density was positively associated with 100-m radius shrubland cover. Southerly latitudes were associated with higher densities when modeled alone, but there was no association when controlling for the covariates. We then examined the relationship between covariates from those plausible models and avian community structure using canonical correspondence analysis to assess the value of Golden-winged Warbler conservation for the broader avian community. We identified 5 species likely to benefit from management for Golden-winged Warblers and 21 species likely to be impacted positively or negatively to varying degrees depending on their affinity for early successional vegetation communities. Golden-winged Warblers ordinated higher along the 100-m shrubland cover gradient than any other bird species, suggesting they may be the most shrubland area-sensitive songbird in our study area. However, the species also requires heavily forested landscapes. Therefore, a species-specific conservation strategy that balances shrubland (patches 9-13 ha comprising $15 \%$ of the landscape) and contiguous forest area ( $\geq 75 \%$ of the landscape) could concurrently meet the needs of Golden-winged Warblers and these 26 other species. 
Keywords: density, detection probability, early succession, elevation, canonical correspondence analysis, shrubland, Vermivora chrysoptera

\section{INTRODUCTION}

Golden-winged Warbler (Vermivora chrysoptera) populations in West Virginia have decreased an average of 8.6\% (95\% confidence interval [CI]: -10.3, -6.5) annually since 1966 (1966-2015 North American Breeding Bird Survey [BBS], Sauer et al. 2017). Contemporary BBS trends are increasingly unreliable (2005-2015: -7.8\% per year [95\% CI -12.9, 0.6]) because Golden-winged Warblers are so rare in West Virginia and throughout the Appalachians (Rosenberg et al. 2016a). In the face of these declines, the Golden-winged Warbler Working Group aims to double the current Appalachian Mountain population by 2050 (Roth et al. 2012), from 22,000 to 44,000 individuals based on population estimates from Partners in Flight (Rich et al. 2004, Rosenberg and Blancher 2005). Meeting this population objective will require ongoing conservation management into the foreseeable future because of the Golden-winged Warbler's reliance on shrublands and young forests for nesting (Scott et al. 2010, Confer et al. 2011).

Conservation actions such as the Working Lands for Wildlife partnership and state-level activities through the Golden-winged Warbler breeding season conservation plan are underway to create and maintain vegetation communities needed to sustain breeding populations of Golden-winged Warblers in the Appalachian Mountains (Roth et al. 2012, U.S. Natural Resources Conservation Service 2012). Region-specific studies of nesting ecology and breeding territories are available to guide these conservation efforts (Rossell et al. 2003, Bulluck and Buehler 2008, Patton et al. 2010, Aldinger and Wood 2014, Aldinger et al. 2015, Frantz et al. 2016). However, few region-specific multi-scale spatial evaluations of abundance have been completed (Bakermans et al. 2015), despite evidence for geographic variation in breeding habitat use throughout the Appalachian Mountain region (Golden-winged Warbler Working Group 2013). Of particular need are studies using multiple ecologically-relevant spatial scales representing different components of the Golden-winged Warbler's hierarchical resource utilization process (Johnson 1980), such as extra-territorial movements to seek extra-pair copulation (Frantz et al. 2016), nest-site selection (Terhune et al. 2016), or other scale-dependent behaviors. Such studies allow stronger inference about abundance patterns because of the link to specific life-history characteristics and the reduction of bias associated with choosing arbitrary 
scales (i.e., the modifiable areal unit problem, Gehlke and Biehl 1934). Finally, multi-scale spatial studies of abundance more clearly direct managers about where to work on the landscape and how to manage selected sites.

The status of the Golden-winged Warbler population in West Virginia arguably warrants conservation action, but consideration of other species is justified because $62 \%$ of successional or scrub and $27 \%$ of forest breeding birds are also declining in the Appalachian Mountains Bird Conservation Region (Sauer et al. 2017). Many of these declining species coexist with Goldenwinged Warblers during at least a portion of their breeding cycle because of the broad range of successional stages and vegetation communities used by breeding Golden-winged Warblers (Streby et al. 2016). Furthermore, species nesting in later stages of succession sometimes use earlier stages of succession during the post-breeding period (McDermott and Wood 2010, King and Schlossberg 2014).

Our overall objective was to identify conditions favorable for high densities of Goldenwinged Warblers, and evaluate the relationship between these conditions and overall avian community structure. First, we modeled Golden-winged Warbler density using habitat covariates at 4 spatial scales representing annual dispersal(5-km radius), extra-territorial movement (1.5$\mathrm{km}$ radius), intra-territorial movement (100-m radius), and local resource utilization (11.3-m radius). We expected that each scale might be similarly important for density (Thogmartin 2010), so we first analyzed each scale separately and then combined covariates from plausible models into a final model suite. We developed multiple alternative hypotheses to explain variation in density and followed an information theoretic approach to evaluate these alternative hypotheses (Burnham and Anderson 2002). Second, we examined the relationship between covariates from those plausible models and avian community structure to evaluate the potential impact of Golden-winged Warbler habitat management on the broader avian community.

\section{METHODS}

\section{Study Area}

During 2008-2015, we conducted point counts and measured vegetation characteristics in Greenbrier, Monongalia, Monroe, Nicholas, Pendleton, Pocahontas, Preston, Randolph, Tucker, and Webster counties, West Virginia $\left(39.6188^{\circ} \mathrm{N}-37.5527^{\circ} \mathrm{N}, 80.6729^{\circ} \mathrm{W}-79.3180^{\circ} \mathrm{W}\right)$, within the contemporary Appalachian Mountain breeding range of the Golden-winged Warbler (Figure 
1; Roth et al. 2012). We selected sites that had existing Golden-winged Warbler nesting cover or potential to create nesting cover through vegetation management. We defined a site as a discrete area with a single management regime resulting in vegetative structure and composition that were relatively uniform within the site. For example, a fenced pasture with livestock grazing and mowing or a ridgetop network of timber harvests each would be considered a site. Sites ( $n=$ 121, 3-494 ha, elevation 547-1,343 meters above sea level) were on the Monongahela National Forest $(n=79)$, State Wildlife Management Areas $(n=3)$, or private land $(n=39)$. Management regimes primarily responsible for creating or maintaining vegetation communities on our sites included active ( $n=42)$ and abandoned ( $n=21)$ livestock grazing, forest management $(n=13)$, herbaceous mowing $(n=13)$, mechanical brush removal $(n=22)$, mine reclamation $(n=3)$, or prescribed fire $(n=7)$. Vegetative conditions varied widely among point count locations at the 100-m scale due to varied management regimes among sites (Figure 2), but forest cover dominated the 1.5-km (median 86\%) and 5-km (median 87\%) scales (Table 1).

\section{Data Collection}

Point counts. Each year before point counts began (April 25-May 19), training of all observers ( $n=9$ total observers, $1-4$ observers per year) was conducted by the same trainer. We practiced distance estimation by estimating known distances. During the $2-3$ days before point counts began, we concurrently, but independently conducted 10 -min practice point counts as a group at the same point count locations and compared our results to help standardize results among observers.

Within sites we randomly distributed point count locations $\geq 250 \mathrm{~m}$ apart (median 2 point count locations per site, range $1-12$ ) to reduce the risk of double counting individual birds (Ralph et al. 1995). We eliminated point count locations with 100\% cover of herbaceous or forest cover within a 100-m radius because Golden-winged Warblers do not breed in these types of vegetation communities (Confer et al. 2011). This design reduced the number of point count locations per site and allowed us to sample a larger number of sites, but ultimately limited our inference about bird communities when herbaceous or forest cover were completely homogeneous. Annually during the peak daily (median 119 min after sunrise, range -13-300 min after sunrise) and seasonal (median June 1, range May 20-June 25) singing period for most songbirds, we conducted 10-min fixed-radius point counts ( $n=1,096$ total point counts during 2008-2015, range 33-323 point counts per year) across 273 point count locations (range 23-235 
point count locations per year) at 121 sites (range 9-99 sites per year). Observers visited point count locations 1-2 times per year dependent on time constraints ( $\geq 12$ days apart if visited twice) for 1-7 years per point (median 3 visits per point, range 1-14 visits). We recorded sky and wind conditions using categories from Hamel et al. (1996). We recorded species, distance category ( $\leq 25 \mathrm{~m},>25-50 \mathrm{~m},>50-75 \mathrm{~m},>75-100$, or $>100 \mathrm{~m}$ ), time $(0-2,>2-3$, >3-4, >4-5, >5-6, >6-7, $>7-8$, or $>8-10 \mathrm{~min}$ ), detection type (call, flyover, song, visual, or non-vocal sound), and sex (male, female, unknown, or juvenile) for each bird detection. We pooled the first 2 minutes to allow sufficient time for an observer to record all birds detected instantaneously at the start of the point count. Thus, individuals could not be placed into minute 2, rather than minute 1, solely based on the order in which the individuals were recorded. We also pooled the last 2 minutes to reduce the sparsity of our count matrices for detection probability analysis.

Geospatial data. We used ArcGIS 10.3 (ESRI 2011) for all geospatial analysis. We used a 30-m resolution National Elevation Dataset digital elevation model (U.S. Geological Survey 1999) to derive aspect $\left(^{\circ}\right)$ and slope $\left(^{\circ}\right)$ grids. We used the slope grid to derive a flow direction grid and the flow direction grid to derive a flow accumulation grid. We then used these grids to calculate a topographic wetness index (TWI) as $\ln \left(A_{s} / \tan \beta\right)$, where $A_{s}$ is the specific catchment area (area $\left(\mathrm{m}^{2}\right)$ per unit width orthogonal to the flow direction) and $\beta$ is the slope angle [in radians] (Gessler et al. 1995).

We manually digitized land cover at a scale of 1:10,000 using 2011 National Agriculture Imagery Program (NAIP) imagery (1-m cell size collected during the growing season). We chose the 2011 imagery because it corresponded with the approximate midpoint of our study. Two sites experienced major land cover change during 2014-2015 because of timber harvests, so we created annual land cover maps for those sites. We digitized land cover for polygons $\geq 0.2$ ha to avoid overly tedious manual digitization while accounting for the minimum reported size of a Golden-winged Warbler territory (0.2 ha, Confer et al. 2011). Our land cover classes included barren (non-vegetation), forest (nearly 100\% closed canopy consisting of trees $>10 \mathrm{~cm} \mathrm{dbh}$ ), herbaceous (dominated by grasses and forbs with $<30 \%$ woody cover), shrubland ( $\geq 30 \%$ shrub cover generally dominated by $\leq 10 \mathrm{~cm}$ dbh stems of species such as autumn olive [Elaeagnus umbellata], hawthorn [Crataegus spp], multiflora rose [Rosa multiflora], and shrubby St. John's wort [Hypericum prolificum] with scattered canopy trees and herbaceous understory), and young forest (regenerating forest stands generally resulting from timber harvest, dominated by saplings 
$\leq 10 \mathrm{~cm}$ dbh, displaying distinct edges against surrounding forest, and often dissected by logging roads).

We incorporated open-water (West Virginia GIS Technical Center [WVGISTC] 2006), man-made structure (West Virginia Statewide Addressing and Mapping Board 2004), and road (WVGISTC 2010) polygons into our land cover map. We buffered structures represented as points with a $154 \mathrm{~m}^{2}$ square, representing the median house size outside of metropolitan statistical areas during 1973-2010 (U.S. Census Bureau 2010). We buffered road centerlines based on their type, with primary roads (e.g., interstate 68) buffered by $8 \mathrm{~m}$, secondary roads by 5 m (e.g., U.S. route 219), local neighborhood, rural roads, and city streets by 3.7 m (e.g., county route 1 ), and all other roads by $1.35 \mathrm{~m}$. We vetted open-water, man-made structure, and road polygons against 2011 NAIP imagery and corrected inconsistencies to increase the accuracy of our final land cover map.

We delineated edges between early-successional woody vegetation (shrubland and young forest) and forest (hereafter, “Edge”). We considered early-successional woody vegetation and forest as sharing an edge if they were within $3 \mathrm{~m}$ of each other as a means of separating ecotones from rural road edges. We calculated Shannon's equitability (Pielou 1966) as $H / \ln (S)$, where $H$ is Shannon's diversity index $\left(-\sum_{i=1}^{s} p_{i} \times \ln \left(p_{i}\right)\right.$; Shannon 1948) and $\ln (S)$ is the natural $\log$ of the number of land cover classes $(S)$. We used the proportions $\left(p_{i}\right)$ of herbaceous, forest, shrubland, and young forest land cover classes in the calculation for each buffer. Values for Shannon's equitability range from zero to one with one representing even proportions of the 4 land cover classes.

Field vegetation data. At a subset of point count locations $(n=967$ point counts at 174 point count locations on 75 sites), we collected breeding-season specific (median date June 30, range June 7-September 14) vegetation data within an 11.3-m radius plot centered on the point count location. By June 7 on our sites, most plants have reached full leaf development. We measured basal area of woody plants from plot center using a 10-factor prism. Similar to Nudds (1977), we estimated vegetation density by placing a board ( $2 \mathrm{~m}$ tall, $40 \mathrm{~cm}$ wide) $10 \mathrm{~m}$ from plot center in each of the 4 cardinal directions and recording how many of the twenty 20-cm squares were $<50 \%$ visible to another observer standing at plot center. We divided the number of squares $<50 \%$ visible by the total number of squares (20) on the board to obtain the vegetation density percentage for each direction, then averaged the 4 percentages for a single estimate of 
vegetation density per point count location. Across the 11.3-m radius plot, we visually estimated average height of the shrub and sapling layer. At least 2 observers independently estimated height, then averaged the estimates and rounded to the nearest $0.25 \mathrm{~m}$. We also measured percent cover of grasses, forbs, vines, Rubus, shrubs, saplings (1-10 cm diameter and $\geq 1 \mathrm{~m}$ tall), and canopy trees (>10 cm dbh) based on ocular tube "hits" (James and Shugart 1970) at 5 points along 11.3-m transects radiating from plot center in each cardinal direction. Observers recorded whether each cover type intersected the ocular tube crosshairs when viewing through the ocular tube straight towards the ground and straight up. We divided the number of "hits" per cover type by the total number of possible "hits" (20) for a single estimate of cover per cover type per point count location. For all field vegetation data, analyses, results, and interpretations, we considered Rubus separate from shrubs and woody plants because of its abundance and importance to Golden-winged Warblers on these sites (Aldinger and Wood 2014).

\section{Data Analysis}

Golden-winged Warbler detection probability. To account for imperfect detection of Golden-winged Warbler males during 100-m radius point counts, we combined distancesampling (Buckland et al. 2001) and time-removal (Farnsworth et al. 2002) methods following Sólymos et al. (2013) to model the 2 components of detection probability (the probability that a bird is detected during a point count): availability (the probability that a bird is available for detection) and perceptibility (the probability that an observer detects a bird, given that it is available for detection). We then used estimates of availability and perceptibility and the area sampled ( $\pi \times$ point count radius ${ }^{2}$ ), as offsets to convert counts to density.

We used package detect 0.3-2 (Sólymos et al. 2014) within program R (used for this and all subsequent analyses; R Development Core Team 2016) to formulate conditional multinomial maximum likelihood models of availability and perceptibility as functions of covariates. We considered each point count $(n=1,096)$ as an independent sample when modeling detection probability (Sólymos et al. 2013). Candidate availability models included continuous covariates for date and time since sunrise, which we rescaled by dividing by their maximum possible values of 365 days and 1,440 min, respectively (Sólymos et al. 2013). We used package maptools 0.836 (Lewin-Koh and Bivand 2015) to obtain sunrise times. Candidate perceptibility models included continuous covariates for herbaceous, forest, and shrubland cover within a 100-m radius and categorical covariates for sky and wind codes and observer. We pooled 2 observers with the 
fewest point counts ( $n=43$ point counts pooled) so the observer model would run without error. To compare among candidate availability models and among candidate perceptibility models, we used Akaike's Information Criterion (AIC, Burnham and Anderson 2002) within package MuMIn 1.15.6 (Barton 2016). We accounted for model-selection uncertainty using a parametric bootstrap procedure ( $n=1,000$ replicates with replacement) to produce model-averaged detection probability offsets (Supporting Information in Sólymos et al. 2013). The probability of selecting a candidate availability or perceptibility model was proportional to its Akaike model weight.

Golden-winged Warbler density modeling. We used package Ime4 1.1-11 (Bates et al. 2015) to formulate Poisson lognormal mixed effect Golden-winged Warbler density models fitted with Laplace approximation. In each model, we included random intercepts for year and for point count ID nested within site. This random-effects structure accounted for annual variation in density (Sauer et al. 2017), non-independence of point count locations within sites, and repeated measurements at individual point count locations within sites (Bates et al. 2015). Golden-winged Warblers can be detected nearly perfectly with 10-minute point counts, especially with repeated counts, (Aldinger and Wood 2015), so we did not use zero-inflated models (Martin et al. 2005).

Variables at different spatial scales may be important in predicting Golden-winged Warbler density (Thogmartin 2010), so we organized candidate models into 5 model suites. Model suites I-IV each represented a different spatial scale. A priori candidate density models for model suites I (5.0-km scale), II (1.5-km scale), and III (100-m scale) included fixed effects for geospatial covariates (Table 2) and used all 1,096 point counts. A priori candidate density models for model suite IV included fixed effects for vegetation covariates measured in the field (Table 2) and used all point counts for which we had field vegetation data $(n=967)$. The fifth and final model suite integrated all spatial scales by using all possible combinations of the plausible models from model suites I-IV.

We chose a 5.0-km radius for covariates in model suite I because $\sim 5.0 \mathrm{~km}$ was the largest between-season movement we observed for color-banded Golden-winged Warblers (K.R.A., personal observation). Model suite I also included northing of the point count location because sites followed a primarily latitudinal gradient spanning $230 \mathrm{~km}$ (Figure 1). The 1.5-km radius for covariates in model suite II reflected the distance of within-season movements of radio-tagged 
Golden-winged Warbler males (Frantz et al. 2016). The 100-m radius for covariates in model suite III corresponded with the spot-mapped territory size of Golden-winged Warblers from this region (2.4 ha $\pm 0.5 \mathrm{SE}$, Frantz et al. 2016) and matched our point count radius. Geospatial covariates representing the same characteristic at different but spatially-nested extents tend to be highly positively correlated because each spatial scale partly measures the same information (Zuur et al. 2009). Therefore, we created 3 non-overlapping concentric rings (0-100-m, >100-m1.5-km, and $>1.5-5.0-\mathrm{km}$ rings) around each point count location. Concentric rings represent a pre-modeling method of reducing collinearity analogous to the model-based approach of constructing linear combinations of spatially-nested covariates (Chatterjee and Price 1991), with the advantage that regression coefficients retain a simple interpretation. Creating concentric rings was necessary because model suite V (see Covariate and model selection) contained covariates from multiple spatial scales. Hereafter, we refer to each scale by the outer radius of the concentric ring followed by the covariate name (Table 2). For example, forest cover within the $1.5-5.0-\mathrm{km}$ ring is called " $5.0-\mathrm{km}$ forest cover".

For each covariate in each model suite, we included a model with a linear term and a model with linear and quadratic terms. We included quadratic terms because Golden-winged Warbler breeding habitat includes a complex mosaic of different vegetation types (Confer et al. 2011) and correlation of density with vegetative cover may change direction as the vegetation community becomes more or less homogenous. For model suites I, II, and III, we included models combining covariates for minimum elevation and forest cover, elevation and shrubland cover, elevation and young forest cover, and shrubland and young forest cover (i.e. nesting cover). For model suite IV, we included models combining covariates for grass and forb (i.e., herbaceous) cover; Rubus, sapling, and shrub (i.e. woody) cover; grass, forb, vine, Rubus, shrub, and sapling (i.e. nesting gestalt); shrub and sapling height (i.e. woody plant height); and vegetation density and grass and forb cover. All model suites also included an intercept-only model for comparison.

We used a non-parametric bootstrap technique ( $n=1,000$ replicates with replacement) to incorporate uncertainty associated with parameter estimates from availability and perceptibility models into our density models and to estimate regression parameters and associated errors for those density models (Sólymos et al. 2013). We created an index for the bootstrap iterations that accounted for the study design, by resampling sites first and then point count locations within 
sites ( $n=1,096$ samples). We used the same bootstrap index for all candidate density models so that replicates $\left(B_{1}, B_{2}, \ldots B_{\mathrm{n}}\right)$ could be directly compared among models (i.e. replicate $B i$ used the same set of $n$ samples across all candidate density models). We derived fixed-effect coefficients, random-effect standard deviations, and model predictions for a model by calculating the median across the 1,000 bootstrap model replicates and estimated 95\% quantile confidence intervals (QCI) using the 2.5\% and 97.5\% quantiles of those replicates (Breiman 1996).

Covariate and model selection. Within and between scales we excluded one of any pair of covariates with a Pearson's product moment correlation coefficient $\geq|0.9|$ from density modeling in order to be conservative in excluding potentially important covariates. In each pair, we generally retained the covariate that we felt had simpler interpretation or management application. For example, we chose to retain 1.5-km forest cover over 1.5-km Shannon’s equitability because proportion of forest cover in an area is simpler to understand and manage than an index representing the relative proportions of 4 different land cover classes. We excluded 5-km Edge (vs. 5-km shrubland cover), 5-km Shannon's equitability (vs. 5-km forest cover and 5-km herbaceous cover), 5-km herbaceous cover (vs. 5-km cover), 5-km minimum elevation (vs. 1.5-km minimum elevation), 1.5-km Shannon’s equitability (vs. 1.5-km forest cover), and 1.5$\mathrm{km}$ herbaceous cover (vs. 1.5-km forest cover).

To compare among candidate models in each model suite, we used AIC (Burnham and Anderson 2002) within package MuMIn 1.15.6 (Barton 2016). We calculated the evidence ratio $(E)$, or the normalized relative likelihood, for each candidate model as $E=e^{0.5 \Delta A I C}$, where $\triangle \mathrm{AIC}$ is the AIC value of the candidate model minus the minimum AIC value in the model suite (Burnham and Anderson 2002). Given our non-parametric bootstrap approach, we calculated $E$ during each bootstrap replicate, then calculated median $E$ across all bootstrap replicates. We defined models with median $E \leq 2.7$ as plausible (Burnham and Anderson 2002). We considered median $E$ to be a conservative indicator of the plausibility of each candidate model for Goldenwinged Warbler density. For each model, we also calculated the proportion $(M)$ of bootstrap replicates $(n=1,000)$ when that model was plausible.

When we had identified plausible models within each model suite, we used the plausible models to build model suite $\mathrm{V}$, representing a hierarchical resource utilization process (Johnson 1980) for Golden-winged Warblers. We formulated new models using all possible combinations of the plausible models in model suites I-IV and used the same analytic approach described 
above for model suites I-IV. For all model suites, we considered covariates in plausible models to be “biologically important” if the fixed effect coefficient 95\% QCI did not overlap zero.

Avian community structure. We used the cca function in package vegan 2.3-5 (Oksanen et al. 2016) to perform canonical correspondence analysis (CCA), a constrained ordination technique combining multiple regression and correspondence analysis, to visualize avian community structure. We used non-flyover detections of adult male birds within a 100-m radius to construct a matrix of species' annual mean relative abundances at sites ( $n=121$ sites) on which to run the CCA. To derive this matrix, we calculated the maximum number of males detected across within-year visits to each point count location, then averaged across point count locations within each site, then averaged across years for each site. We excluded species with males detected on $<10 \%$ of sites. Removing rare species can have negligible effects on ordinations (McCune and Grace 2002, Pos et al. 2014). We also excluded Ruby-throated Hummingbird (Archilochus colubris) because it was usually detected by sight only (69\% of detections), suggesting a markedly different detection process than more vocal songbirds. We excluded American Goldfinch (Spinus tristis) because it breeds primarily after our point count period (McGraw and Middleton 2009). We used “biologically important” covariates (i.e. fixed effect coefficient 95\% QCI did not overlap zero) from the plausible models in model suite V as constraining covariates in CCA. We evaluated the CCA ordination by examining partitioned variance, correlation $\left(\mathrm{R}^{2}\right.$ ), adjusted $\mathrm{R}^{2}$ (Peres-Neto et al. 2006), and significance of permutation tests ( $n=1,000$ permutations; Borcard et al. 2011) and considered results statistically significant at $\alpha=0.05$.

To further examine the relationship of the constraining covariates to the avian community structure, we used the ordisurf function in package vegan 2.3-5 to fit smooth surfaces for each constraining covariate using generalized additive models with thin plate splines (Oksanen et al. 2016). To derive a single site-level covariate value to correspond with the matrix of species’ relative abundances, we averaged covariate values across year for each point count location, then averaged across point count locations within each site. We used symmetric scaling for ordination diagrams (Gabriel 2002) and displayed linear combination scores so that the ordisurf surface was analogous to environmental vectors traditionally used with CCA (Oksanen et al. 2016). We used an ordisurf surface rather than the environmental vectors traditionally used with CCA so that we could evaluate the position of each species in the ordination relative to values of the constraining 
covariates. We considered species to be associated with Golden-winged Warblers if they were ordinated within the range of values of the constraining covariates known to be associated with greater than median Golden-winged Warbler density based on our density modeling.

\section{RESULTS}

\section{Golden-winged Warbler Detection Probability}

Across 1,096 100-m radius point counts during May-June 2008-2015, we recorded 225 detections of male Golden-winged Warblers (range 0-3 males per point count). The mostsupported model of availability included linear and quadratic terms for date, and 2 additional models had $\Delta$ AIC $\leq 2.0$ (Table 3). The most-supported model of perceptibility included a linear term for 100-m forest cover, and a model with linear and quadratic terms for 100-m forest cover also was plausible ( $\triangle \mathrm{AIC}=1.4$, Table 3$)$. Among plausible models, availability was negatively associated with date and time since sunrise and perceptibility was negatively associated with 100-m forest cover.

\section{Golden-winged Warbler Density}

Two models were plausible in model suite I (5-km geospatial covariates: annual dispersal scale): one with a linear term for northing $(E=1.0, M=0.9)$ and one with a linear and a quadratic term for northing ( $E=2.0, M=0.8$; Figure 5). Both models indicated that Golden-winged Warbler density was inversely associated with latitude (Table 4).

A single model with a linear and a quadratic term for 1.5-km minimum elevation was plausible ( $E=1.0, M=0.9)$ in model suite II (1.5-km geospatial covariates: extra-territorial movement scale, Figure 5). Density peaked at intermediate values for 1.5-km minimum elevation (Table 4). A similar pattern should extend to the 5-km scale because of the highly positive correlation (correlation coefficient 0.90 ) between 1.5-km and 5-km minimum elevation that led us to exclude the latter covariate.

In model suite III (100-m geospatial covariates: intra-territorial movement scale), a model with linear terms for 100-m minimum elevation and 100-m shrubland cover $(E=1.0, M=0.8)$ and a model with linear and quadratic terms for 100 -m shrubland cover $(E=1.8, M=0.6)$ were plausible (Figure 5). Golden-winged Warbler density was positively associated with 100-m shrubland cover and negatively associated with 100-m minimum elevation (Table 4). 
No models from model suite IV (field vegetation covariates: local resource utilization scale) had median $E \leq 2.7$ and therefore no models were considered plausible (Figure 6) based on our model-selection criterion. Thus, we did not carry any models over into model suite $\mathrm{V}$ and were able to use the full set of point count data ( $n=1,096$ point counts) for model suite $\mathrm{V}$ rather than the subset with field vegetation data $(n=967)$. Although none of the models were plausible, covariates for vegetation density or sapling cover appeared in each of the top 5 ranked models, suggesting that these covariates may be worth investigating using a slightly different scale or metric.

For model suite V, we evaluated all possible combinations of the plausible models from model suites I-III. The top ranked model $(E=1.0, M=1.0)$ had linear terms for $1.5-\mathrm{km}$ minimum elevation, 100-m minimum elevation, and 100-m shrubland cover and a quadratic term for 1.5-km minimum elevation (Figure 7). A second plausible model had the same structure but with the addition of a linear term for northing $(E=2.5, M=0.9)$. In both models, Golden-winged Warbler density peaked when 1.5-km minimum elevation was $804 \mathrm{~m}$, was negatively associated with 100-m minimum elevation, and was positively associated with 100-m shrubland cover (Table 4, Figure 3). Unlike in model suite I, the 95\% QCI for the northing fixed-effect coefficient overlapped zero (Table 4).

\section{Avian Community Structure}

We detected 129 species and 2 hybrid phenotypes (Brewster's and Lawrence's Warblers) on point counts during 2008-2015 (Table 5). We used 52 species for CCA after excluding 77 species and 2 hybrid phenotypes because they either occurred on $<10 \%$ of sites or exhibited characteristics that made them unsuitable for analysis (American Goldfinch, Ruby-throated Hummingbird). The constrained axes explained $11 \%$ (axis $1=7 \%$, axis $2=3 \%$, axis $3=1 \%$ ) of the variance in the avian community, which when adjusted (adjusted $\mathrm{R}^{2}$ ) decreased to 8\% (axis 1 $=5 \%$, Axis $2=2 \%$, Axis $3=1 \%$ ). The unconstrained axes explained the vast majority (adjusted $\mathrm{R}^{2}=92 \%$ ) of the variation in the avian community, but permutation tests suggested the global CCA model $\left(F_{3,117}=4.6, P=0.001\right)$, all canonical axes (axis $1: F_{1,117}=8.5, P=0.001$; axis 2 : $F_{1,117}=3.6, P=0.001$; axis $\left.3: F_{1,117}=1.6, P=0.023\right)$, and all constraining covariates $(100-\mathrm{m}$ shrubland cover: $F_{1,117}=3.8, P=0.001 ; 100$-m minimum elevation: $F_{1,117}=8.3, P=0.001$; 1.5 km minimum elevation: $F_{1,117}=1.7, P=0.023$ ) were statistically significant. 
By fitting surfaces (rather than vectors) for constraining covariates, we could objectively determine which species grouped with Golden-winged Warbler (Table 5, Figure 4) based on the range of values predicted to be associated with greater than median densities of Golden-winged Warblers (Figure 3). White-eyed Vireo (Vireo griseus), Blue-gray Gnatcatcher (Polioptila caerulea), Gray Catbird (Dumetella carolinensis), Brown Thrasher (Toxostoma rufum), and Yellow Warbler (Setophaga petechia) ordinated with Golden-winged Warblers within the "optimum" ranges of all constraining covariate surfaces (100-m shrubland cover $=52-100 \%$, 100-m minimum elevation $=540-914 \mathrm{~m}, 1.5-\mathrm{km}$ minimum elevation $=602-1,006 \mathrm{~m}$; Figure 4). We consider these species as most likely to benefit from conservation strategies aimed at maximizing Golden-winged Warbler density. Twenty-one species ordinated within the “optimum” ranges of 1.5-km and 100-m minimum elevation (Figure 4). We consider these species most likely to be impacted, to varying degrees either positively or negatively, by management for Golden-winged Warblers because they predominantly occur at elevations that would be considered for management. Species ordinated closer to the 52\% line for $100-\mathrm{m}$ shrubland cover, such as American Redstart (Setophaga ruticilla), are more likely to benefit from or at least tolerate increases to 100-m shrubland cover. Conversely, species ordinated at lower values for 100-m shrubland cover, such as Hooded Warbler (Setophaga citrina), are more likely to be negatively impacted by increases to $100-\mathrm{m}$ shrubland cover.

\section{DISCUSSION}

Our results confirmed and refined existing knowledge about Golden-winged Warbler populations in the Appalachian Mountain region, particularly regarding elevation (Crawford et al. 2016) and shrubland cover (Aldinger and Wood 2014). We found evidence of a previously undocumented hierarchical resource utilization process (Johnson 1980), wherein Golden-winged Warbler density showed spatial-scale-dependent associations with elevation. At the 100-m radius scale, Golden-winged Warbler density was negatively associated with minimum elevation and peaked at $540 \mathrm{~m}$, the lowest $100-\mathrm{m}$ minimum elevation value we sampled. But at the $1.5-\mathrm{km}$ radius scale, Golden-winged Warbler density peaked at $804 \mathrm{~m}$, near the midpoint of the range of 1.5-km minimum elevation values we sampled. This knowledge enhances conservation planning by identifying the most important variables favoring high densities of Golden-winged Warblers in a way that accounts for multiple spatial scales relevant to the species' life history. Finally, we 
extended our findings to the broader avian community and formulated objective criteria that identified 5 species likely to benefit from Golden-winged Warbler management and 21 species likely to be impacted positively or negatively proportional to their affinity for early successional vegetation communities. Our results serve an informative role for future comprehensive modeling efforts (e.g., Peterson et al. 2016) and for organizations involved in local conservation efforts in West Virginia (e.g., U.S. Forest Service, U.S. Natural Resources Conservation Service, and West Virginia Division of Natural Resources).

\section{Golden-winged Warbler Density}

The connection between Golden-winged Warblers and elevation is well-documented - the prevailing knowledge being that higher elevations ( $>500 \mathrm{~m})$ are preferred up to a point $(<1,200$ m) in the central Appalachian Mountains (Crawford et al. 2016, Rosenberg et al. 2016a). Studies in the Appalachian Mountain region have explicitly evaluated elevation as a covariate (Welton 2003, Patton et al. 2010, Bakermans et al. 2015) or considered it an important study design component (Bulluck and Buehler 2008, Aldinger and Wood 2015). Nonetheless, our understanding of the role of elevation is incomplete because these studies generally did not consider multiple spatial scales concurrently. This is reflected in the practice of selecting sites for Golden-winged Warbler management based on whether the site itself, not the surrounding area, is above an elevation threshold (K.R.A., personal observation). Had we evaluated a single spatial scale corresponding to our point count radius, we might have incompletely concluded that Golden-winged Warbler management was suitable at a much broader range of sites given the shape and direction of the association between density and 100-m minimum elevation (optimum 100-m minimum elevation $=540-914 \mathrm{~m}$ with the peak at $540 \mathrm{~m}$, Figure 3). However, many of these sites would not be suitable for Golden-winged Warblers because elevations within 1.5-km are $<602 \mathrm{~m}$ or $>1,006 \mathrm{~m}$. And while it is important not to make inference outside the range of data in general (Conn et al. 2015), readers may have been tempted to forecast the densityelevation association below the range of our data again given its shape and direction.

Applying results without the context of the larger geographical landscape and existing knowledge in this case could lead to decisions that exacerbate Golden-winged Warbler population declines by encouraging contact with Blue-winged Warblers (Vermivora cyanoptera) along the western slopes of the Allegheny Mountains at elevations around $500 \mathrm{~m}$ (Crawford et al. 2016). Blue-winged Warblers consistently replace Golden-winged Warblers through 
hybridization within 50 years of initial contact (Gill 1980, Rosenberg et al. 2016a). Concurrently modeling multiple scales instead led to the conclusion that high-elevation landscapes (optimum $1.5-\mathrm{km}$ minimum elevation $=602-1,006 \mathrm{~m}$ with the peak at $804 \mathrm{~m}$ ) provide refugia for Goldenwinged Warblers, perhaps even at local (100-m scale) elevations that would otherwise be inhabited by Blue-winged Warblers. Because the 1.5-km and 5-km scales correspond to withinseason extra-territorial movements (Frantz et al. 2016) and annual dispersal (K.R.A., personal observation), respectively, these mid- to high-elevation landscapes may buffer Golden-winged Warbler populations from extra-pair mating attempts and immigration by Blue-winged Warblers. We consider 2 hypotheses as likely explanations for the shape and direction of the 100-m spatial-scale association between Golden-winged Warbler density and elevation (Figure 3). First, Golden-winged Warblers were found at elevations below contemporary levels (Crawford et al. 2016) until relatively recently (nearly to the Ohio River, Brooks 1940) and may be new inhabitants of the West Virginia highlands (Rives 1898, Brooks 1944). Thus, the inverse correlation between density and elevation at the $100-\mathrm{m}$ scale may be a relic of the species' historic distribution preserved by the surrounding higher-elevation landscape (1.5-km minimum elevation: 602-1,006 m). Our second hypothesis is that vegetation communities capable of supporting higher densities of Golden-winged Warblers more often occur on lower-elevation side slopes and valleys rather than on higher-elevation mountain peaks. The former generally are better suited for agriculture, the predominant source of Golden-winged Warbler nesting cover in our study area (Aldinger and Wood 2014, Aldinger et al. 2015). A study using controlled experimental plots at different elevations may be able to address these hypotheses.

The other biologically important covariate in our top Golden-winged Warbler density model, shrubland cover, has also been previously identified (Hanowski 2002, Bulluck and Buehler 2008, Roth et al. 2012, Aldinger and Wood 2014). In the most similar reference we found, Golden-winged Warblers were absent from point counts in Minnesota and Wisconsin when 100 -m shrubland cover was $<10 \%$ (Hanowski 2002). Our raw point count data showed that we likewise failed to detect Golden-winged Warblers when 100 -m shrubland cover was $<11 \%$, but density did not reach higher than median levels until 100 -m shrubland cover was $>52 \%$. At the other end of the compositional spectrum, our models suggested that density was greatest when $100-\mathrm{m}$ shrubland cover was $100 \%$. A 100 -m radius circle composed purely of shrubland (3.1 ha) is one quarter the size of the largest recommended contiguous circular patch (12.6 ha) of 
early-successional cover for the species ( $<200 \mathrm{~m}$ to nearest older age-class forest, Rohrbaugh et al. 2016). A minimum of 9-10 ha of shrubland may be preferred by nesting Golden-winged Warblers (Confer and Knapp 1981, Roth et al. 2014). Therefore, managing circular patches of contiguous shrubland cover 9-12.6 ha in size surrounded by older age-class forest may ensure that Golden-winged Warblers use the entire patch. Higher densities may be achieved within each patch by arranging multiple patches in a network with $<2 \mathrm{~km}$ between patches (Bakermans et al. 2015). Irregularly-shaped patches or patches with embedded islands of canopy trees (Roth et al. 2014) may be preferred to create larger extents of Golden-winged Warbler nesting cover. A scale-variant compositional analysis conditioned on Golden-winged Warbler abundance or occupancy where cover type is evaluated as a function of scale would further improve guidelines for the optimum proportion of shrubland in a given area.

Consistent in density modeling and field observations was an emphasis on shrubland rather than young forest cover. We detected zero Golden-winged Warblers on point counts in locations classified as young forest ( $n=79$ point counts, $n=27$ point count locations, $n=13$ sites) despite the range of ages (1-20+ breeding seasons after timber harvest) and, consequently, stages of vegetative succession sampled. While our data show a preference for shrublands over young forest, Golden-winged Warblers do breed in young forest cover elsewhere in their range (Klaus and Buehler 2001, Patton et al. 2010, Bakermans et al. 2015) and occasionally in West Virginia (R. S. Bailey, pers. comm.). Historically in West Virginia, the Golden-winged Warbler was a fixture of the "chestnut sprout association” (Brooks 1940), a term describing the young forest cover resulting from mass die-off of American chestnut (Castanea dentata). Thus, an alternative explanation for the apparent preference for shrublands over young forests is that contemporary forest management practices in our area may be inadequate for nesting Goldenwinged Warblers. The most common timber-harvest method in West Virginia is partial harvesting, especially diameter-limit harvests where only merchantable trees greater than a designated diameter are cut (62\% of harvests in McGill et al. 2006, 80\% or harvests in Fajvan et al. 1998). Partial harvesting generally does not remove enough trees to create nesting cover for Golden-winged Warblers (Weakland et al. 2002). Furthermore, partial harvesting can decrease forest productivity and shift tree species composition toward shade-tolerant species (Schuler 2004), which could reduce future opportunities to harvest timber in a way that would benefit Golden-winged Warblers. Young forests that we sampled were the result of even-aged forest 
management where nearly all trees in an area were cut, which is an uncommon practice in West Virginia (Fajvan et al. 1998). When even-aged management does occur, it is unlikely that adequate nesting cover will develop by chance since management practices, including timber harvesting, specifically planned to create nesting cover can even fall short of attaining the vegetation characteristics recommended in the species' conservation plan (Roth et al. 2012, McNeil et al. 2017). Critical steps in conservation of the species in West Virginia may therefore be to (1) create and maintain shrubland vegetation communities (Golden-winged Warbler Working Group 2013) and (2) promote species-specific forest-management guidelines (Bakermans et al. 2011), especially within 2 km of known Golden-winged Warbler breeding populations on shrublands (Bakermans et al. 2015). The latter step will elucidate whether Golden-winged Warblers exhibit a preference for shrubland over young forest or if changes to forest management practices are needed.

\section{Avian Community Structure}

Our second objective was to translate covariate levels associated with greater than median densities of Golden-winged Warblers into implications for the broader avian community. The most important covariates associated with Golden-winged Warbler density explained just 8\% of the variation in the avian community, probably due to our short list of constraining variables. Still, the global CCA model, all constrained axes, and all constraining variables were statistically significant and the ordination plot and fitted surfaces were intuitive and corroborated our Golden-winged Warbler density modeling, warranting further interpretation.

The list of species most closely associated with high densities of Golden-winged Warblers was relatively short, suggesting the species may have limited value as a surrogate for conservation of the larger avian community (Caro and O’Doherty 1999). However, a broader consideration of temporal and spatial scale is warranted before dismissing the surrogate species concept altogether. Our data represent a temporal snapshot of the nesting period for most songbirds in our study area, based on morning singing behavior. Vegetation communities used during morning singing bouts during the nesting period may not be representative of the range of vegetation communities used throughout the course of an entire day. Golden-winged Warblers in Minnesota used forest cover more in the afternoon compared to the morning, presumably for prolonged foraging bouts (Streby et al. 2012). Ovenbirds in Saskatchewan, on the other hand, displayed the opposite trend and moved away from interior forest in the afternoon (Mazerolle 
and Hobson 2003). Similarly, cover types used for nesting may not be representative of the range of cover types used during the entire breeding season. Songbird species that nest in early successional vegetation communities may raise their fledglings in forest cover and vice versa (King and Schlossberg 2014, Streby et al. 2016). Analogous arguments may be made for spatial scale. Core areas of a bird's territory used for conspicuous activities such as nesting and singing may differ markedly from peripheral areas used for foraging or rearing fledglings (McDermott and Wood 2010, Streby et al. 2016). Finally, the scales of our constraining covariates are relatively local compared to the species' geographic distribution across the Allegheny Mountains of West Virginia. Thus, at longer temporal and broader spatial scales, management for Goldenwinged Warbler nesting cover likely benefits or is at least compatible with more species than our results indicate. A management approach that aims to create dynamic forested landscapes (Roth et al. 2012) with empirically-derived age-class distribution targets (Johst et al. 2011) across broader scales ( $>5$-km radius) may be the preferred approach to benefit Golden-winged Warblers and many other bird species.

Specifically for shrubland-nesting birds, our ordination suggests that Golden-winged Warblers may be the most area-sensitive in our study area because they ordinated further along the 100-m shrubland cover gradient than any other species. This pronounced area sensitivity, along with hybridization with Blue-winged Warblers, may help to explain why Golden-winged Warbler populations have declined faster than all but Bewick's Wren (Thryomanes bewickii) among shrubland-nesting birds in the Appalachian Mountains Bird Conservation Region (Sauer et al. 2017). Given our results, managing for Golden-winged Warblers would meet the needs of other shrubland-nesting bird species requiring smaller areas of shrubland (Watson et al. 2001). Such an interpretation has merit because many songbirds in eastern North America are threatened primarily by limited abundance of early-successional vegetation communities (King and Schlossberg 2014). Still, incorporating the unique ecology of each species and tracking individual species through an adaptive management framework to the extent possible remain important facets of a conservation strategy focused on a single species (Lindenmayer et al. 2002).

Of the 5 species most likely to benefit from Golden-winged Warbler management (Table 5, Figure 4), only Brown Thrasher is listed as a priority species in the region (Appalachian Mountains Joint Venture Management Board 2008). Of the 21 species most likely to be impacted 
because they predominantly occur at elevations associated with greater than median densities of Golden-winged Warblers (Table 5), 7 are listed as priority species (Appalachian Mountains Joint Venture 2008, West Virginia Division of Natural Resources 2015, Rosenberg et al. 2016b). One of the most pertinent of these species is the Wood Thrush (Hylocichla mustelina) because of its high priority ranking by multiple conservation groups (Table 5) and association with large tracts of unbroken forest (Evans et al. 2011), placing the species seemingly at odds with the Goldenwinged Warbler. Forest fragmentation and edge density, both potentially increasing in the landscape when managing for Golden-winged Warbler, are negatively associated with nest survival of Wood Thrush (Driscoll et al. 2005). However, Wood Thrush require shrubland and young forest during the post-breeding period (Vega Rivera et al. 1998). Furthermore, landscape forest cover recommendations for Golden-winged Warblers in the Appalachian Mountains region ( $\geq 75 \%$, Wood et al. 2016) would likely moderate edge effects for Wood Thrush (Driscoll and Donovan 2004) and other species (Hunter et al. 2001). Therefore, recommendations calling for $15 \%$ of heavily forested landscapes to be maintained in shrubland and young forest cover (Bakermans et al. 2015) could benefit both Wood Thrush and Golden-winged Warbler, among other species, if planned to minimize fragmentation of large tracts of later successional forest (Bonnot et al. 2013).

Brown-headed Cowbirds (Molothrus ater) also ordinated within elevations associated with greater than median densities of Golden-winged Warblers. Cowbirds sometimes are listed as an important threat to Golden-winged Warbler populations because of brood parasitism (Buehler et al. 2007, Confer et al. 2011). A review of published literature found that parasitism rates varied geographically from 0 to 35\% (Aldinger 2010), and a recent book on Golden-winged Warblers mentioned Brown-headed Cowbirds only one time (Streby et al. 2017). These disparate reports suggest that impacts of Brown-headed Cowbird brood parasitism on Golden-winged Warblers are localized. In fact, across 2 studies including 429 Golden-winged Warbler nests in West Virginia, no nests were parasitized (Canterbury et al. 1996, Aldinger and Wood 2014). The lack of parasitism may be due to the $>82 \%$ cover of forests within the Golden-winged Warbler's range in West Virginia (Morin et al. 2016). Forest cover is negatively associated with parasitism rate (Cox et al. 2012). However, given that cowbirds occurred at 32\% of sites (Table 5), more abundant alternate hosts also may be diluting the effects of parasitism on the rarer Goldenwinged Warbler (Barber and Martin 1997). To avoid increasing parasitism rates, the relative 
positions of Golden-winged Warbler and Brown-headed Cowbird in our ordination suggest maximizing 100-m shrubland cover, which reduces 100-m herbaceous cover that likely attracts Brown-headed Cowbirds.

Blue-winged Warblers merit mention because they hybridize with and generally replace Golden-winged Warblers (Gill 1980, Rosenberg et al. 2016a). However, the Blue-winged Warbler's position in our ordination only overlapped the range of 100-m minimum elevation associated with greater than median densities of Golden-winged Warblers. This result contextualizes our findings from density modeling and provides a more mechanistic understanding of the complex relationship between Golden-winged Warblers, Blue-winged Warblers, and elevation. We infer that an important pathway for Blue-winged Warblers to hybridize with and replace Golden-winged Warblers is through extra-territorial movements of Blue-winged Warblers at lower elevations seeking extra-pair copulation with nearby (within 1.5 km) Golden-winged Warblers at higher elevations. We sampled multiple sites during 2008-2015 with Golden-winged Warblers and hybrids without documenting any Blue-winged Warbler males or females on the site during intensive banding, territory mapping, and nest searching (K.R.A., personal observation). Focusing conservation efforts on higher values for 100-m minimum elevation and to the right-hand side of the peak (804 m) of 1.5-km minimum elevation (Figure 3) may reduce the risk of contact between the 2 species.

\section{Conclusion}

For single-species management of Golden-winged Warblers in the West Virginia Highlands, the most important covariates are 1.5-km minimum elevation: 602-1,006 m, 100-m minimum elevation: 540-914 m, and 100-m shrubland cover: 52-100\%. The important application for conservation planners in our area is to consider minimum elevation $1.5 \mathrm{~km}$ or even $5 \mathrm{~km}$ beyond the site boundary, which will influence whether extra-territorial movements and dispersal into the site will consist of Golden-winged Warblers or Blue-winged Warblers. Twenty-six species seemed likely to be impacted in some way by management for Golden-winged Warblers, yet only White-eyed Vireo, Blue-gray Gnatcatcher, Gray Catbird, Brown Thrasher, and Yellow Warbler were strongly associated with shrubland cover and elevation favored by Golden-winged Warblers. Still, we suggest that Golden-winged Warblers may be the most shrubland areasensitive songbird in our study area, yet still requires heavily forested landscapes (Wood et al. 
2016). Management meeting these requirements could concurrently meet the needs of Goldenwinged Warblers and these 26 other species.

\section{ACKNOWLEDGMENTS}

The Littlefield family, West Virginia Cooperative Fish and Wildlife Research Unit, and West Virginia Division of Natural Resources Elkins Operation Center provided housing. Numerous private landowners, the U.S. Forest Service Monongahela National Forest, and West Virginia Division of Natural Resources allowed access to study sites. We thank J. Aldinger, I. Batterman, P. Bryant, A. Dalton, M. Frantz, C. Fitzmorris, N. Glover, J. Kreiser, C. Lauzau, K. Loucks, S. Malinich, A. Newman, V. Olmstead, K. Pratt, M. Roach, C. Roy, J. Saborse, C. Sedgwick, L. Smith, L. Stout, D. Ware, and M. Weston for long hours of work in the field. J. Anderson, Z. Loman, G. Merovich, P. Sólymos, M. Strager, R. Tallman, and members of the Golden-winged Warbler Working Group provided valuable insight during this research.

Funding statement: The West Virginia Division of Natural Resources Wildlife Diversity Program (013555.2.1000502W), U.S. Fish and Wildlife Service Migratory Bird Program (F12AP00643), U.S. Forest Service Monongahela National Forest (12-PA-11092100-020), U.S. Natural Resources Conservation Service (68-7482-12-502), and the National Fish and Wildlife Foundation (10012877.1.1004706R) granted funding for this research. Co-author C.M.J. is affiliated with the U.S. Forest Service Monongahela National Forest, one of the funding sources. None of the funders required approval of the manuscript before submission or publication. Any use of trade, firm, or product names is for descriptive purposes only and does not imply endorsement by the U.S. Government.

Ethics statement: This study was completed under the auspices of West Virginia University Institutional Animal Care and Use Committee protocols 07-0303 and 10-0201.

Author contributions: K.R.A. and P.B.W. conceived the idea, design, and experiment and formulated hypotheses. K.R.A., P.B.W., and C.M.J. developed and refined methods and contributed substantial materials and resources. K.R.A. conducted the research, analyzed the data, and wrote the manuscript. P.B.W. and C.M.J. substantially edited the manuscript.

\section{LITERATURE CITED}


Aldinger, K. R. (2010). Playback surveys and breeding habitat characteristics of Golden-winged Warblers (Vermivora chrysoptera) on high-elevation pasturelands on the Monongahela National Forest, West Virginia. Master's thesis, West Virginia University, Morgantown, WV, USA.

Aldinger, K. R., and P. B. Wood. (2014). Reproductive success and habitat characteristics of Golden-winged Warblers in high-elevation pasturelands. The Wilson Journal of Ornithology 126:279-287.

Aldinger, K. R., and P. B. Wood. (2015). Variables associated with detection probability, detection latency, and behavioral responses of Golden-winged Warblers (Vermivora chrysoptera). The Condor 117:364-375.

Aldinger, K. R., T. M. Terhune II, P. B. Wood, D. A. Buehler, M. H. Bakermans, J. L. Confer, D. J. Flaspohler, J. L. Larkin, J. P. Loegering, K. L. Percy, A. M. Roth, and C. G. Smalling. (2015). Variables associated with nest survival of Golden-winged Warblers (Vermivora chrysoptera) among vegetation communities commonly used for nesting. Avian Conservation and Ecology 10:6.

Appalachian Mountains Joint Venture Management Board. (2008). Implementation plan for the Appalachian Mountains Join Venture: a foundation for all-bird conservation in the region (B. W. Smith, Editor). Appalachian Mountains Joint Venture, Frankfort, KY, USA.

Bakermans, M. H., J. L. Larkin, B. W. Smith, T. M. Fearer, and B. C. Jones. (2011). Goldenwinged Warbler habitat best management practices for forestlands in Maryland and Pennsylvania. American Bird Conservancy, The Plains, VA, USA.

Bakermans, M. H., B. W. Smith, B. C. Jones, and J. L. Larkin. (2015). Stand and within-stand factors influencing Golden-winged Warbler use of regenerating stands in the central Appalachian Mountains. Avian Conservation and Ecology 10:10.

Barber, D. R., and T. E. Martin. (1997). Influence of alternate host densities on Brown-headed Cowbird parasitism rates in Black-capped Vireos. Condor 99:595-604.

Barton, K. (2016). MuMIn: Multi-model inference. R package 1.15.6. https://cran.rproject.org/package=MuMIn.

Bates, D., M. Maechler, B. Bolker, and S. Walker. (2015). Fitting linear mixed-effects models using lme4. Journal of Statistical Software 67:1-48.

Bonnot, T. W., F. R. Thompson III, J. J. Millspaugh, and D. T. Jones-Farrand. (2013). Landscape-based population viability models demonstrate importance of strategic conservation planning for birds. Biological Conservation 165:104-114.

Borcard, D., F. Gillet, and P. Legendre. (2011). Numerical ecology with R. Springer, New York, NY, USA.

Breiman, L. (1996). Bagging predictors. Machine Learning 24:123-140.

Brooks, M. (1940). The breeding warblers of the central Allegheny Mountain region. The Wilson Bulletin 52:249-266.

Brooks, M. (1944). A check-list of West Virginia birds. West Virginia Agriculture Experiment Station, Bulletin 316. West Virginia University, Morgantown, WV, USA. 
Buckland, S. T., D. R. Anderson, K. P. Burnham, J. L. Laake, D. L. Borchers, and L. Thomas. (2001). Introduction to distance sampling: estimating abundance of biological populations. Oxford University Press, Oxford, UK.

Buehler, D. A., A. M. Roth, R. Vallender, T. C. Will, J. L. Confer, R. A. Canterbury, S. B. Swarthout, K. V. Rosenberg, and L. P. Bulluck. Status and conservation priorities of Golden-winged Warbler (Vermivora chrysoptera) in North America. Auk 124:14391445.

Bulluck, L. P., and D. A. Buehler. (2008). Factors influencing Golden-winged Warbler (Vermivora chrysoptera) nest-site selection and nest survival in the Cumberland Mountains of Tennessee. The Auk 125:551-559.

Burnham, K. P., and D. R. Anderson. (2002). Model selection and multimodel inference: a practical information-theoretic approach, 2nd ed. Springer-Verlag, New York, NY, USA.

Canterbury, R. A., D. M. Stover, and J. J. Kotesovec Jr. (1996). Population ecology of Goldenwinged Warblers in southern West Virginia. West Virginia Division of Natural Resources, Elkins, WV, USA.

Caro, T. M., and G. O’Doherty. (1999). On the use of surrogate species in conservation biology. Conservation Biology 13:805-814.

Chandler, C. C., D. I. King, and R. B. Chandler. (2012). Do mature forest birds prefer earlysuccessional habitat during the post-fledging period? Forest Ecology and Management 264:1-9.

Chatterjee, S., and B. Price. (1991). Regression analysis by example, 2nd ed. John Wiley and Sons, New York, NY, USA.

Confer, J. L., P. Hartman, and A. Roth. (2011). Golden-winged Warbler (Vermivora chrysoptera). In The Birds of North America Online (P. Rodewald, Editor). Cornell Laboratory of Ornithology, Ithaca, NY, USA. http://bna.birds.cornell.edu/bna/species/gowwar.

Conn, P. B., D. S. Johnson, P. L. Boveng. (2015). On extrapolating past the range of observed data when making statistical predictions in ecology. PLoS One 10:1-16.

Cox, W. A., F. R. Thompson III, and J. Faaborg. (2012). Landscape forest cover and edge effects on songbird nest predation vary by predator. Landscape Ecology 27:659-669.

Crawford, D. L., R. W. Rohrbaugh, A. M. Roth, J. D. Lowe, S. Barker Swarthout, and K. V. Rosenberg. (2016). Landscape-scale habitat and climate correlates of breeding Goldenwinged and Blue-winged warblers. In Golden-winged Warbler Ecology, Conservation, and Habitat Management (H. M. Streby, D. E. Andersen, and D. A. Buehler, Editors). Studies in Avian Biology 49:41-66.

Driscoll, M. J. L., and T. M. Donovan. (2004). Landscape context moderates edge effects: nesting success of Wood Thrushes in central New York. Conservation Biology 18:13301338.

Driscoll, M. J. L., T. M. Donovan, R. Mickey, A. Howard, and K. K. Fleming. (2005). Determinants of Wood Thrush nest success: a multi-scale, model selection approach. Journal of Wildlife Management 69:699-709. 
ESRI. (2011). ArcGIS Desktop: Release 10. Environmental Systems Research Institute, Redlands, CA, USA.

Evans, M., E. Gow, R. R. Roth, M. S. Johnson, and T. J. Underwood. (2011). Wood Thrush (Hylocichla mustelina). In The Birds of North America Online (P. Rodewald, Editor). Cornell Laboratory of Ornithology, Ithaca, NY, USA. http://bna.birds.cornell.edu/bna/species/woothr.

Fajvan, M. A., S. T. Grushecky, and C. C. Hassler. (1998). The effects of harvesting practices on West Virginia’s wood supply. Journal of Forestry 96:33-39.

Farnsworth, G. L., K. H. Pollock, J. D. Nichols, T. R. Simons, J. E. Hines, and J. R. Sauer. (2002). A removal model for estimating detection probabilities from point count surveys. Auk 119:414-425.

Frantz, M. W., K. R. Aldinger, P. B. Wood, J. Duchamp, T. Nuttle, A. Vitz, and J. L. Larkin. (2016). Space and habitat use of breeding Golden-winged Warblers in the central Appalachian Mountains. In Golden-winged Warbler Ecology, Conservation, and Habitat Management (H. M. Streby, D. E. Andersen, and D. A. Buehler, Editors). Studies in Avian Biology 49:81-94.

Gabriel, K. R. (2002). Goodness of fit of biplots and correspondence analysis. Biometrika 89:423-436.

Gehlke, C. E., and K. Biehl. (1934). Certain effects of grouping upon the size of the correlation coefficient in census tract material. Journal of the American Statistical Association 29:169-170.

Gessler, P. E., I. D. Moore, N. J. McKenzie, and P. J. Ryan. (1995). Soil-landscape modelling and spatial prediction of soil attributes. International Journal of Geographic Information Systems 9:421-432.

Gill, F. B. (1980). Historical aspects of hybridization between Blue-winged and Golden-winged Warblers. The Auk 97:1-18.

Golden-winged Warbler Working Group. (2013). Best management practices for Golden-winged Warbler habitats in the Appalachian region. www.gwwa.org/plan.

Hamel, P. B., W. P. Smith, D. J. Twedt, J. R. Woehr, E. Morris, R. B. Hamilton, and R. J. Cooper. (1996). A land manager's guide to point counts of birds in the southeast. USDA Forest Service General Technical Report SO-120.

Hanowski, J. M. (2002). Habitats and landscapes used by breeding Golden-winged Warblers in western Great Lakes forests. The Loon 74:127-133.

Hunter, W. C., D. A. Buehler, R. A. Canterbury, J. L. Confer, and P. B. Hamel. (2001). Conservation of disturbance-dependent birds in eastern North America. Wildlife Society Bulletin 29:440-455.

James, F. C., and H. H. Shugart, Jr. (1970). A quantitative method of habitat description. Audubon Field Notes 24:727-736.

Johnson, D. H. (1980). The comparison of usage and availability measurements for evaluating resource preference. Ecology 61:65-71. 
Johst, K, M. Drechsler, A. J. A. van Teeffelen, F. Hartig, C. C. Vos, S. Wissel, F. Wätzold, and P. Opdam. (2011). Biodiversity conservation in dynamic landscapes: trade-offs between number, connectivity and turnover of habitat patches. Journal of Applied Ecology 48:1227-1235.

King, D. I., and S. Schlossberg. (2014). Synthesis of the conservation value of the earlysuccessional stage in forests of eastern North America. Forest Ecology and Management 324:186-195.

Klaus, N. A., and D. A. Buehler. (2001). Golden-winged Warbler breeding habitat characteristics and nest success in clearcuts in the southern Appalachian Mountains. The Wilson Bulletin 113:297-301.

Lambeck, R. J. (1997). Focal species: a multi-species umbrella for nature conservation. Conservation Biology 11:849-856.

Lewin-Koh, N. J., and R. Bivand. (2015). Package 'maptools': tools for reading and handling spatial objects. R package 0.8-36. https://cran.r-project.org/package=maptools.

Lindenmayer, D. B., A. D. Manning, P. L. Smith, H. P. Possingham, J. Fischer, I. Oliver, and M. A. McCarthy. (2002). The focal species approach and landscape restoration: a critique. Conservation Biology 16:338-345.

Martin, T. G., B. A. Wintle, J. R. Rhodes, P. M. Kuhnert, S. A. Field, S. J. Low-Choy, A. J. Tyre, and H. J. Possingham. (2005). Zero-tolerance ecology: improving ecological inference by modelling the source of zero observations. Ecology Letters 8:1235-1246.

Mazerolle, D. F., and K. A. Hobson. (2003). Do Ovenbirds (Seiurus aurocapillus) avoid boreal forest edges? A spatiotemporal analysis in an agricultural landscape. Auk 120:152-162.

McDermott, M. E., and P. B. Wood. (2010). Influence of cover and food resource variation on post-breeding use of timber harvests with residual canopy trees. The Wilson Journal of Ornithology 122:545-555.

McGill, D. W., D. J. Magill, J. Kochenderfer, M. Ford, and T. Schuler. (2004). Information transfer during the timber transaction period in West Virginia, USA. In: Proceedings, 7th extension working party symposium, communication strategies for multiple partner involvement in forest extension. IUFRO working party 6.06.03 extension, Orvieto, Italy.

McGraw, K. J., and A. L. Middleton. (2009). American Goldfinch (Spinus tristis). In The Birds of North America Online (P. Rodewald, Editor). Cornell Laboratory of Ornithology, Ithaca, NY, USA. https://birdsna.org/Species-Account/bna/species/amegfi.

McNeil, D. J., K. R. Aldinger, M. H. Bakermans, J. A. Lehman, A. C. Tisdale, J. A. Jones, P. B. Wood, D. A. Buehler, C. G. Smalling, L. Siefferman, and J. L. Larkin. (2017). An evaluation and comparison of conservation guidelines for an at-risk migratory songbird. Global Ecology and Conservation 9:90-103.

Morin, R. S., G. W. Cook, C. J. Barnett, B. J. Butler, S. J. Crocker, M. A. Hatfield, C. M. Kurtz, T. W. Lister, W. G. Luppold, W. H. McWilliams, P. D. Miles, M. D. Nelson, C. H. Perry, R. J. Piva, J. E. Smith, J. A. Westfall, R. H. Widmann, and C. W. Woodall. (2016). West Virginia forests, 2013. U.S. Department of Agriculture Forest Service Resource Bulletin NRS-105. 
Nudds, T. D. (1977). Quantifying the vegetative structure of wildlife cover. The Wildlife Society Bulletin 5:113-117.

Oksanen, J., F.G. Blanchet, R. Kindt, P. Legendre, P. R. Minchin, R. B. O'Hara, G. L. Simpson, P. Sólymos, M. Henry, H. Stevens, and H. Wagner. (2016). vegan: Community Ecology Package. R package 2.3-5. https://CRAN.R-project.org/package=vegan.

Patton, L. L., D. S. Maehr, J. E. Duchamp, S. Fei, J. W. Gassett, and J. L. Larkin. (2010). Do the Golden-winged Warbler and Blue-winged Warbler exhibit species-specific differences in their breeding habitat use? Avian Conservation and Ecology 5:2.

Peres-Nato, P. R., P. Legendre, S. Dray, and D. Borcard. (2006). Variation partitioning of species data matrices: estimation and comparison of fractions. Ecology 87:2614-2625.

Peterson S. M., H. M. Streby, and D. E. Andersen. (2016). Spatially-explicit models of fullseason productivity and implications for landscape management of Golden-winged Warblers in the western Great Lakes region. In Golden-winged Warbler Ecology, Conservation, and Habitat Management (H. M. Streby, D. E. Andersen, and D. A. Buehler, Editors). Studies in Avian Biology 49:141-160.

Pielou, E. C. (1966). Shannon's formula as a measure of species diversity: its use and misuse. The American Naturalist 100:463-465.

Pos, E., J. E. Guevara Andino, D. Sabatier, J. F. Molino, N. Pitman, H. Mogollón, D. Neill, C. Cerón, G. Rivas, A. Di Fiore, R. Thomas et al. (2014). Are all species necessary to reveal ecologically important patterns? Ecology and Evolution 4:4626-4636.

R Development Core Team. (2016). R: A language and environment for statistical computing. Version 3.2.5. R Foundation for Statistical Computing. Vienna, Austria. www.rproject.org.

Ralph, C. J., J. R. Sauer, and S. Droege (Editors). (1995). Monitoring bird populations by point counts. USDA Forest Service General Technical Report PSW-GTR-149.

Rich, T. D., C. J. Beardmore, H. Berlanga, P. J. Blancher, M. S. W. Bradstreet, G. S. Butcher, D. W. Demarest, E. H. Dunn, W. C. Hunter, E. E. I nigo-Elias, J. A. Kennedy, et al. (2004). Partners in Flight North American Landbird Conservation Plan. Cornell Lab of Ornithology, Ithaca, NY, USA.

Rives, W. V. (1898). The summer birds of the West Virginia spruce belt. The Auk 15:131-137.

Roberge, J., and P. Angelstam. (2004). Usefulness of the umbrella species concept as a conservation tool. Conservation Biology 18:76-85.

Rosenberg, K. V., and P. J. Blancher (2005). Setting numerical population objectives for priority landbird species. In Bird Conservation and Implementation in the Americas: Proceedings of the Third International Partners in Flight Conference, vol. 1 (C. J. Ralph and T. D. Rich, Editors). USDA Forest Service General Technical Report PSW-GTR-191. pp. 5767.

Rosenberg, K. V., T. Will, D. A. Buehler, S. Barker Swarthout, W. E. Thogmartin, R. E. Bennett, and R. B. Chandler. (2016a). Dynamic distributions and population declines of Golden-winged Warblers. In Golden-winged Warbler Ecology, Conservation, and 
Habitat Management (H. M. Streby, D. E. Andersen, and D. A. Buehler, Editors). Studies in Avian Biology 49:3-28.

Rosenberg, K. V., J. A. Kennedy, R. Dettmers, R. P. Ford, D. Reynolds, J. D. Alexander, C. J. Beardmore, P. J. Blancher, R. E. Bogart, G. S. Butcher, A. F. Camfield, et al. (2016b). Partners in Flight Landbird Conservation Plan: 2016 Revision for Canada and Continental United States. Partners in Flight Science Committee.

Rossell Jr., C. R., S. C. Patch, S. P. Wilds. (2003). Attributes of Golden-winged Warbler territories in a mountain wetland. The Wildlife Society Bulletin 31:1099-1104.

Roth, A. M., D. J. Flaspohler, and C. R. Webster. (2014). Legacy tree retention in young aspen forest improves nesting habitat quality for Golden-winged Warbler (Vermivora chrysoptera). Forest Ecology and Management 321:61-70.

Roth, A. M. and S. Lutz. (2004). Relationship between territorial male Golden-winged Warblers in managed aspen stands in northern Wisconsin, USA. Forest Science 50:153-161.

Roth, A. M., R. W. Rohrbaugh, K. R. Aldinger, M. H. Bakermans, S. Barker Swarthout, D. A. Buehler, J. L. Confer, D. Crawford, C. Friis, R. M. Fowlds, J. L. Larkin, et al. (2012). Golden-winged Warbler breeding season conservation plan. In Golden-winged Warbler Status Review and Conservation Plan (A. M. Roth, R. W. Rohrbaugh, T. Will, and D. A. Buehler, Editors). www.gwwa.org/plan.

Sauer, J. R., D. K. Niven, J. E. Hines, D. J. Ziolkowski, Jr., K. L. Pardieck, J. E. Fallon, and W. A. Link. (2017). The North American Breeding Bird Survey, Results and Analysis 19662015. Version 02.07.2017 USGS Patuxent Wildlife Research Center, Laurel, MD, USA.

Schuler, T. M. (2004). Fifty years of partial harvesting in a mixed mesophytic forest: composition and productivity. Canadian Journal of Forest Research 34:985-997.

Shannon, C. E. (1948). A mathematical theory of communication. Bell System Technical Journal 27:379-423.

Sólymos, P., S. M. Matsuoka, E. M. Bayne, S. R. Lele, P. Fontaine, S. G. Cumming, D. Stralberg, F. K. A. Schmiegelow, and S. J. Song. (2013). Calibrating indices of avian density from non-standardized survey data: making the most of a messy situation. Methods in Ecology and Evolution 4: 1047-1058.

Sólymos, P., M. Moreno, and S. R. Lele. (2014). Detect: analyzing wildlife data with detection error. R package 0.3-2. https://cran.r-project.org/package=detect.

Streby, H. M., D. E. Andersen, and D. A. Buehler, Editors. (2017). Golden-winged Warbler Ecology, Conservation, and Habitat Management. Studies in Avian Biology, CRC Press, Boca Raton, FL, USA.

Streby, H. M., J. P. Loegering, and D. E. Andersen. (2012). Spot-mapping underestimates songterritory size and use of mature forest by breeding Golden-winged Warblers in Minnesota, USA. The Wildlife Society Bulletin 36:40-46.

Streby, H. M., S. M. Peterson, D. E. Andersen. (2016). Survival and habitat use of fledgling Golden-winged Warblers in the western Great Lakes region. In Golden-winged Warbler Ecology, Conservation, and Habitat Management (H. M. Streby, D. E. Andersen, and D. A. Buehler, Editors). Studies in Avian Biology 49:127-140. 
Terhune II, T. M., K. R. Aldinger, D. A. Buehler, D. J. Flaspohler, J. L. Larkin, J. P. Loegering, K. L. Percy, A. M. Roth, C. Smalling, and P. B. Wood. (2016). Golden-winged Warbler nest-site habitat selection. In Golden-winged Warbler Ecology, Conservation, and Habitat Management (H. M. Streby, D. E. Andersen, and D. A. Buehler, Editors). Studies in Avian Biology 49:109-125.

Thogmartin, W. E. (2010). Modeling and mapping Golden-winged Warbler abundance to improve regional conservation strategies. Avian Conservation and Ecology 5:2.

U.S. Census Bureau. (2010). Median and average square feet of floor area in new single-family houses completed by location. U.S. Census Bureau, Washington, DC, USA. www.census.gov/const/C25Ann/sftotalmedavgsqft.pdf.

U.S. Geological Survey. (1999). National elevation dataset (West Virginia subset). U.S. Geological Survey, EROS Data Center, Sioux Falls, SD, USA. www.wvgis.wvu.edu/data/dataset.php?ID=29.

U.S. Natural Resources Conservation Service. (2012). Working lands for wildlife. USDA Natural Resources Conservation Service, Washington, DC, USA.

www.nrcs.usda.gov/wps/portal/nrcs/detailfull/national/programs/financial/whip/?cid=stel prdb1046990.

Vega Rivera, J. H., J. H. Rappole, W. J. McShea, and C. A. Haas. (1998). Wood Thrush postfledgling movements and habitat use in northern Virginia. The Condor 100:69-78.

Weakland, C. A., P. B. Wood, and W. M. Ford. (2002). Responses of songbirds to diameter-limit cutting in the central Appalachians of West Virginia, USA. Forest Ecology and Management 155:115-129.

West Virginia Division of Natural Resources. (2015). West Virginia State Wildlife Action Plan. West Virginia Division of Natural Resources, Wildlife Resources Section, South Charleston, WV, USA. http://www.wvdnr.gov/DRAFT\%202015\%20WV\%20State\%20 Wildlife\%20Action\%20Plan\%20R1.pdf.

West Virginia GIS Technical Center. (2006). Streams (SAMB 1:4,800 scale). West Virginia GIS Technical Center, Morgantown, WV, USA. wvgis.wvu.edu/data/dataset.php?ID=265.

West Virginia GIS Technical Center. (2010). Roads and railroads (1990, 2000, and 2010 Census TIGER/Line). West Virginia GIS Technical Center, Morgantown, WV, USA. wvgis.wvu.edu/data/dataset.php?ID=238.

West Virginia Statewide Addressing and Mapping Board. (2004). SAMB building points and polygons. West Virginia Statewide Address and Mapping Board, Charleston, WV, USA. wvgis.wvu.edu/data/dataset.php?ID=288.

Wood, E. M., S. Barker Swarthout, W. M. Hochachka, J. L. Larkin, R. W. Rohrbaugh, K. V. Rosenberg, and A. D. Rodewald. (2016). Intermediate habitat associations by hybrids may facilitate genetic introgression in a songbird. Journal of Avian Biology 47:001-013.

Zuur, A. F., E. N. Ieno, N. J. Walker, A. A. Saveliev, and G. M. Smith. (2009). Mixed effects models and extensions in ecology with R. Springer Science and Business Media, New York, NY, USA. 


\section{TABLES}

Table 1. Summary statistics for covariates (see Table 2 for covariate notation) used in Goldenwinged Warbler density modeling and redundancy analysis in West Virginia, 2008-2015. Summary statistics are based on site-level covariate values, derived by averaging covariate values across years for each point count location $(n=273)$, then averaging across point count locations within each site $(n=121)$.

\begin{tabular}{|c|c|c|c|c|c|c|}
\hline Covariate & Min. & $1^{\text {st }}$ quartile & Median & Mean & $3^{\text {rd }}$ quartile & Max. \\
\hline \multicolumn{7}{|c|}{ 5-km geospatial covariates: annual dispersal scale } \\
\hline Northing $(\mathrm{km})$ & 4156.6 & 4230.7 & 4245.4 & 4256.2 & 4285.7 & 4385.6 \\
\hline Forest cover (\%) & 59.2 & 80.9 & 87.4 & 85.4 & 91.7 & 97.3 \\
\hline Herbaceous cover (\%) & 0.0 & 3.4 & 5.8 & 8.1 & 11.5 & 30.7 \\
\hline Young forest cover (\%) & 0.0 & 0.3 & 0.7 & 1.2 & 1.5 & 9.1 \\
\hline Shrubland cover (\%) & 0.0 & 1.5 & 2.8 & 3.8 & 5.7 & 13.3 \\
\hline Shannon's equitability & 0.1 & 0.2 & 0.3 & 0.3 & 0.4 & 0.8 \\
\hline Edge $\left(\mathrm{km} / \mathrm{km}^{2}\right)^{\mathrm{a}}$ & 0.2 & 0.6 & 0.8 & 0.9 & 1.2 & 2.2 \\
\hline Minimum elevation (m) & 265 & 616 & 679 & 694 & 781 & 969 \\
\hline \multicolumn{7}{|c|}{ 1.5-km geospatial covariates: extra-territorial movement scale } \\
\hline Forest cover (\%) & 36.7 & 75.9 & 86.5 & 82.9 & 93.2 & 99.7 \\
\hline Herbaceous cover (\%) & 0.0 & 1.5 & 5.3 & 8.5 & 9.5 & 50.7 \\
\hline Young forest cover (\%) & 0.0 & 0.0 & 0.1 & 1.0 & 1.5 & 9.7 \\
\hline Shrubland cover (\%) & 0.0 & 1.6 & 3.9 & 6.0 & 9.1 & 29.7 \\
\hline Shannon's equitability & 0.0 & 0.2 & 0.3 & 0.3 & 0.5 & 0.8 \\
\hline Edge $\left(\mathrm{km} / \mathrm{km}^{2}\right)^{\mathrm{a}}$ & 0.0 & 0.7 & 1.1 & 1.3 & 1.7 & 4.2 \\
\hline Minimum elevation (m) & 318 & 675 & 794 & 800 & 916 & 1106 \\
\hline \multicolumn{7}{|c|}{ 100-m geospatial covariates: intra-territorial movement scale } \\
\hline Forest cover (\%) & 0.0 & 13.9 & 28.9 & 34.9 & 52.5 & 100.0 \\
\hline Herbaceous cover (\%) & 0.0 & 0.0 & 7.3 & 13.0 & 21.8 & 84.4 \\
\hline Young forest cover (\%) & 0.0 & 0.0 & 0.0 & 7.9 & 0.0 & 100.0 \\
\hline Shrubland cover (\%) & 0.0 & 8.6 & 44.1 & 42.3 & 69.5 & 99.8 \\
\hline Shannon's equitability & 0.0 & 0.3 & 0.4 & 0.4 & 0.5 & 0.8 \\
\hline Edge $\left(\mathrm{km} / \mathrm{km}^{2}\right)^{\mathrm{a}}$ & 0.0 & 3.3 & 6.0 & 6.5 & 9.2 & 19.8 \\
\hline Minimum elevation (m) & 540 & 786 & 925 & 940 & 1097 & 1309 \\
\hline TWI ${ }^{b}$ & 5.0 & 6.0 & 6.3 & 6.6 & 7.0 & 15.0 \\
\hline \multicolumn{7}{|c|}{ Field vegetation covariates: local resource utilization scale ${ }^{c}$} \\
\hline Vegetation density (\%) & 8.1 & 45.8 & 60.3 & 60.9 & 78.0 & 98.8 \\
\hline Basal area $\left(\mathrm{m}^{2} / \mathrm{ha}\right)$ & 0.0 & 2.1 & 6.3 & 10.9 & 12.5 & 87.5 \\
\hline Grass cover (\%) & 17.5 & 65.5 & 85.0 & 76.0 & 93.1 & 100.0 \\
\hline Forb cover (\%) & 30.6 & 68.3 & 80.0 & 78.0 & 91.1 & 100.0 \\
\hline Vine cover (\%) & 0.0 & 0.0 & 1.3 & 6.5 & 7.1 & 52.1 \\
\hline Rubus cover (\%) & 0.0 & 2.5 & 10.0 & 16.5 & 25.0 & 76.7 \\
\hline Shrub cover (\%) & 0.0 & 11.0 & 21.0 & 25.0 & 39.3 & 70.0 \\
\hline Sapling cover (\%) & 0.0 & 0.0 & 3.6 & 9.7 & 12.5 & 73.3 \\
\hline Canopy cover (\%) & 0.0 & 1.3 & 5.0 & 14.4 & 18.5 & 90.0 \\
\hline Shrub layer height (m) & 0.3 & 1.3 & 2.0 & 2.1 & 2.9 & 4.2 \\
\hline Sapling layer height (m) & 0.0 & 0.8 & 1.8 & 2.1 & 3.0 & 5.9 \\
\hline
\end{tabular}

${ }^{a}$ Density of shrubland-forest and young forest-forest edge

b Topographic wetness index

${ }^{\mathrm{c}} \mathrm{n}=75$ sites with field vegetation data 
Table 2. Descriptions, notations, and justifications for covariates in model suites evaluating the association of geospatial (model suites I, II, and III) and field-vegetation (model suite IV) covariates with Golden-winged Warbler density and early-successional forest and forest-interior priority species richness. We used covariates in each model suite in two models: one with a linear term and one with a linear and a quadratic term. Each model suite also included an intercept-only model.

\begin{tabular}{|c|c|}
\hline Covariate (abbreviation) & Justification \\
\hline UTM $(\mathrm{km})$ northing ${ }^{\mathrm{a}}$ & $\begin{array}{l}\text { Positive association between density and latitude, possibly due } \\
\text { to climate (Thogmartin 2010) }\end{array}$ \\
\hline \multicolumn{2}{|l|}{ Land cover (\%) } \\
\hline Forest ${ }^{\mathrm{a}, \mathrm{b}, \mathrm{c}}$ & $\begin{array}{l}\text { Positive association between density and 5-km forest cover } \\
\text { (Thogmartin 2010); recommended } \geq 60 \% 2.5 \text {-km forest cover } \\
\text { (Crawford et al. 2016) }\end{array}$ \\
\hline Herbaceous $^{c}$ & $\begin{array}{l}\text { Can be the predominant component of territories (Rossell et al. } \\
\text { 2003); needed to fragment shrub or sapling stands for nesting } \\
\text { (Klaus and Buehler 2001, Bakermans et al. 2015) }\end{array}$ \\
\hline Young forest ${ }^{a, b, c}$ & $\begin{array}{l}\text { Positive association between abundance and 1-km young- } \\
\text { forest cover (Bakermans et al. 2015) }\end{array}$ \\
\hline Shrubland ${ }^{a, b, c}$ & $\begin{array}{l}\text { Commonly used nesting cover at high elevations in West } \\
\text { Virginia (Aldinger and Wood 2014) and throughout the } \\
\text { breeding range (Confer et al. 2011) }\end{array}$ \\
\hline $\begin{array}{l}\text { Shannon's equitability using } \\
\text { four land covers (forest, } \\
\text { herbaceous, young forest, } \\
\text { and shrubland) c }\end{array}$ & $\begin{array}{l}\text { Variety of successional stages used during the breeding } \\
\text { season, including herbaceous (Rossell et al. 2003), shrubland } \\
\text { (Aldinger and Wood 2014), young forest (Bakermans et al. } \\
\text { 2015), and forest (Frantz et al. 2016) }\end{array}$ \\
\hline $\begin{array}{l}\text { Density }\left(\mathrm{km} / \mathrm{km}^{2}\right) \text { of } \\
\text { shrubland-forest and young } \\
\text { forest-forest edge }(E d g e)^{\text {b,c }}\end{array}$ & $\begin{array}{l}\text { Edge between shrubland or young forest and later successional } \\
\text { forest is a component of nearly all territories (Patton et al. } \\
\text { 2010, Confer et al. 2011, Frantz et al. 2016) }\end{array}$ \\
\hline Minimum elevation ${ }^{\mathrm{b}, \mathrm{c}}$ & $\begin{array}{l}\text { Elevation }>500 \text { m predicts occurrence and likely limits contact } \\
\text { with Blue-winged Warblers in Appalachian Mountains region } \\
\text { (Crawford et al. 2016) }\end{array}$ \\
\hline $\begin{array}{l}\text { Median topographic wetness } \\
\text { index }(T W I)^{\mathrm{c}}\end{array}$ & $\begin{array}{l}\text { Wetlands may provide local ( } 0.5-5 \text { ha) refugia with increased } \\
\text { genetic purity and nest survival (Confer et al. 2010), but see } \\
\text { Peterson et al. (2016) }\end{array}$ \\
\hline $\begin{array}{l}\text { Basal area }\left(\mathrm{m}^{2} / \mathrm{ha}\right) \text { at point } \\
\text { count location }^{\mathrm{d}}\end{array}$ & $\begin{array}{l}\text { Recommended } 1.9-3.7 \mathrm{~m}^{2} / \text { ha basal area for breeding } \\
\text { territories in the Appalachian region (Golden-winged Warbler } \\
\text { Working Group 2013) }\end{array}$ \\
\hline $\begin{array}{l}\text { Vegetation density (\%) } \\
\text { within } 10 \mathrm{~m}^{\mathrm{d}}\end{array}$ & $\begin{array}{l}\text { Vegetation within } 10 \mathrm{~m} \text { of nest locations was denser than } \\
\text { random locations (Aldinger and Wood 2014); recommended } \\
\text { 10-35\% vegetation density within } 10 \text { m of nests (Terhune et } \\
\text { al. 2016) }\end{array}$ \\
\hline $\begin{array}{l}\text { Mean vegetation height }(\mathrm{m}) \\
\text { within } 11.3 \mathrm{~m}^{\mathrm{d}} \\
\text { Shrub height }\end{array}$ & $\begin{array}{l}\text { Height of woody vegetation may be associated with density } \\
\text { (Roth and Lutz 2004) }\end{array}$ \\
\hline
\end{tabular}




\begin{tabular}{ll}
\hline Covariate (abbreviation) & Justification \\
\hline \multicolumn{1}{c}{ Sapling height } & \\
Cover (\%) within $11.3 \mathrm{~m}^{\mathrm{d}}$ & Vegetation communities used for breeding are characterized \\
Grass & by a complex mosaic of herbaceous and woody vegetation and \\
Forb & canopy trees (Confer et al. 2011, Roth et al. 2012) \\
Vine & \\
Rubus & \\
Shrub & \\
Sapling & \\
Canopy & \\
\hline
\end{tabular}

${ }^{a}$ Model suite I (5-km geospatial covariates: annual dispersal scale)

${ }^{\mathrm{b}}$ Model suite II (1.5-km geospatial covariates: extra-territorial movement scale)

${ }^{\mathrm{c}}$ Model suite III (100-m geospatial covariates: intra-territorial movement scale)

${ }^{\mathrm{d}}$ Model suite IV (field vegetation covariates: local resource utilization scale) 
Table 3. We formulated conditional multinomial maximum likelihood models of availability and perceptibility as functions of covariates using package detect (Sólymos et al. 2013). For continuous covariates (e.g., Date), we formulated models with quadratic terms (e.g., Date + Date $^{2}$ ) because we expected that detection probability may not always demonstrate a straight-line pattern. We evaluated competing models using Akaike's Information Criterion (AIC, Burnham and Anderson 2002). Using a parametric bootstrap approach, we derived model-averaged estimates of availability and perceptibility using model weights $\left(w_{\mathrm{i}}\right) . \mathrm{K}$ is the number of parameters in the model and $-2 \ln L$ is the maximum $\log$ likelihood. We presented all candidate models.

\begin{tabular}{|c|c|c|c|c|}
\hline Model & $\mathbf{K}$ & $-2 \ln L$ & $\Delta \mathrm{AIC}$ & $w_{\mathbf{i}}$ \\
\hline \multicolumn{5}{|l|}{ Availability models $\mathrm{a}$, b } \\
\hline Date + Date $^{2}$ & 3 & 541.6 & 0.0 & 0.37 \\
\hline Date & 2 & 544.7 & 1.1 & 0.21 \\
\hline Date + Date $^{2}+$ TSS & 4 & 541.6 & 2.0 & 0.14 \\
\hline Date + TSS & 3 & 544.6 & 3.0 & 0.08 \\
\hline Date + TSS + TSS $^{2}$ & 4 & 542.7 & 3.1 & 0.08 \\
\hline Intercept only & 1 & 549.9 & 4.3 & 0.04 \\
\hline $\mathrm{TSS}+\mathrm{TSS}^{2}$ & 3 & 546.6 & 5.0 & 0.03 \\
\hline Date + Date $^{2}+$ TSS + TSS $^{2}$ & 5 & 542.7 & 5.1 & 0.03 \\
\hline TSS & 2 & 549.9 & 6.3 & 0.02 \\
\hline \multicolumn{5}{|l|}{ Perceptibility models c, d } \\
\hline 100-m forest cover & 2 & 512.8 & 0.0 & 0.55 \\
\hline 100 -m forest cover $+100-m$ forest cover ${ }^{2}$ & 3 & 512.2 & 1.4 & 0.28 \\
\hline 100-m shrubland cover & 2 & 517.0 & 4.2 & 0.07 \\
\hline Intercept only & 1 & 520.7 & 5.9 & 0.03 \\
\hline Wind & 6 & 516.8 & 5.9 & 0.03 \\
\hline $100-\mathrm{m}$ shrubland cover $+100-\mathrm{m}$ shrubland cover $^{2}$ & 3 & 510.7 & 6.0 & 0.03 \\
\hline 100-m herbaceous cover & 2 & 520.7 & 7.9 & 0.01 \\
\hline Sky + Wind & 10 & 506.0 & 8.8 & 0.01 \\
\hline $100-m$ herbaceous cover +100 -m herbaceous cover ${ }^{2}$ & 3 & 518.2 & 9.9 & 0.00 \\
\hline Observer & 8 & 520.7 & 10.0 & 0.00 \\
\hline Sky & 5 & 510.8 & 11.4 & 0.00 \\
\hline $\begin{array}{l}\text { Time since sunrise (TSS) } \\
\text { binimum AIC = 547.6 } \\
\text { See Table } 2 \text { for covariate notation } \\
\text { d Minimum AIC = 516.8 }\end{array}$ & & & & \\
\hline
\end{tabular}


Table 4. Median fixed effect coefficients, median random effect standard deviations, and 95\% quantile confidence intervals (QCI) for plausible models (median evidence ratio $\leq 2.7$ ) in each model suite. Model suite IV had no plausible models.

\begin{tabular}{|c|c|c|c|c|c|}
\hline \multirow{2}{*}{$\begin{array}{l}\text { Model } \\
\text { suite }\end{array}$} & \multirow[b]{2}{*}{ Fixed effect } & \multirow{2}{*}{$\begin{array}{l}\text { Fixed effect coefficient } \\
\text { (95\% QCI) }\end{array}$} & \multicolumn{3}{|c|}{ Random effect standard deviation (95\% QCI) } \\
\hline & & & Point Count ID & Site & Year \\
\hline \multirow[t]{5}{*}{ I } & Intercept & $-0.5(-1.5,0.6)$ & $1.2(0.8,1.8)$ & $1.7(1.0,3.2)$ & $0.4(0.2,0.6)$ \\
\hline & Northing & $-4.5(-6.1,-3.0)$ & & & \\
\hline & Intercept & $-2.6(-5.5,0.0)$ & $1.2(0.8,1.8)$ & $1.7(0.9,3.0)$ & $0.4(0.2,0.6)$ \\
\hline & Northing & $4.8(-5.1,15.4)$ & & & \\
\hline & Northing ${ }^{2}$ & $-8.9(-18.7,-0.3)$ & & & \\
\hline \multirow[t]{3}{*}{ II } & Intercept & $-59.4(-76.3,-43.3)$ & $1.4(0.9,2.0)$ & $0.4(0.0,1.4)$ & $0.4(0.2,0.6)$ \\
\hline & $\begin{array}{l}\text { 1.5-km minimum } \\
\text { elevation }\end{array}$ & $149.8(107.8,194.2)$ & & & \\
\hline & $\begin{array}{l}\text { 1.5-km minimum } \\
\text { elevation }{ }^{2}\end{array}$ & $-95.7(-124.1,-69.1)$ & & & \\
\hline \multirow[t]{6}{*}{ III } & Intercept & $-0.6(-2.7,1.2)$ & $1.0(0.7,1.5)$ & $0.4(0.0,1.7)$ & $0.4(0.2,0.6)$ \\
\hline & $\begin{array}{l}\text { 100-m minimum } \\
\text { elevation }\end{array}$ & $-4.8(-6.9,-2.5)$ & & & \\
\hline & $\begin{array}{l}\text { 100-m shrubland } \\
\text { cover }\end{array}$ & $4.3(3.2,5.5)$ & & & \\
\hline & Intercept & $-7.0(-10.6,-5.3)$ & $0.8(0.5,1.2)$ & $1.3(0.5,2.5)$ & $0.4(0.2,0.6)$ \\
\hline & $\begin{array}{l}100 \text {-m shrubland } \\
\text { cover }\end{array}$ & $12.1(6.9,22.0)$ & & & \\
\hline & $\begin{array}{l}\text { 100-m shrubland } \\
\text { cover }^{2}\end{array}$ & $-6.4(-13.2,-2.7)$ & & & \\
\hline \multirow[t]{11}{*}{$\mathrm{V}$} & Intercept & $-60.9(-79.2,-45.2)$ & $0.7(0.4,1.0)$ & $0.0(0.0,0.2)$ & $0.4(0.2,0.6)$ \\
\hline & $\begin{array}{l}\text { 1.5-km minimum } \\
\text { elevation }\end{array}$ & $161.4(119.4,209.6)$ & & & \\
\hline & $\begin{array}{l}\text { 1.5-km minimum } \\
\text { elevation }{ }^{2}\end{array}$ & $-102.1(-132.1,-76.0)$ & & & \\
\hline & $\begin{array}{l}\text { 100-m shrubland } \\
\text { cover }\end{array}$ & $3.9(2.9,4.9)$ & & & \\
\hline & $\begin{array}{l}\text { 100-m minimum } \\
\text { elevation }\end{array}$ & $-6.6(-8.8,-4.7)$ & & & \\
\hline & Intercept & $-61.0(-85.5,-41.0)$ & $0.7(0.4,1.0)$ & $0.0(0.0,0.2)$ & $0.4(0.2,0.6)$ \\
\hline & Northing & $0.1(-2.3,2.8)$ & & & \\
\hline & $\begin{array}{l}\text { 1.5-km minimum } \\
\text { elevation }\end{array}$ & $161.7(111.7,220.4)$ & & & \\
\hline & $\begin{array}{l}\text { 1.5-km minimum } \\
\text { elevation }\end{array}$ & $-102.3(-138.1,-71.1)$ & & & \\
\hline & $\begin{array}{l}\text { 100-m shrubland } \\
\text { cover }\end{array}$ & $3.9(2.8,4.9)$ & & & \\
\hline & $\begin{array}{l}\text { 100-m minimum } \\
\text { elevation }\end{array}$ & $-6.7(-9.1,-4.6)$ & & & \\
\hline
\end{tabular}


Table 5. Species detected on point counts during May-June 2008-2015. For canonical correspondence analysis, we excluded species when non-flyover detections of males occurred on fewer than 10\% of sites across 2008-2015 (see “\% male occurrence" column). We also excluded Ruby-throated Hummingbird because they exhibit limited vocalizations and American Goldfinch because they are somewhat non-territorial, wide-ranging, gregarious, and breed later than most other songbirds. An " $X$ " in the appropriate column indicates if the species' position in the ordination overlapped the range of values for the constraining variable associated with greater than median Golden-winged Warbler density (1.5-km minimum elevation $=602-1,006 \mathrm{~m}, 100$ $\mathrm{m}$ minimum elevation $=540-914 \mathrm{~m}, 100-\mathrm{m}$ shrubland cover $=52-100 \%)$.

\begin{tabular}{|c|c|c|c|c|c|c|}
\hline Common name & Abbr. & Scientific name & $\begin{array}{c}\text { \% male } \\
\text { occurrence }\end{array}$ & $\begin{array}{c}\text { 1.5-km } \\
\text { minimum } \\
\text { elevation }\end{array}$ & $\begin{array}{c}100-\mathrm{m} \\
\text { minimum } \\
\text { elevation }\end{array}$ & $\begin{array}{c}100-\mathrm{m} \\
\text { shrubland } \\
\text { cover }\end{array}$ \\
\hline Canada Goose & CANG & Branta canadensis & 0 & & & \\
\hline Wood Duck ${ }^{\mathrm{e}}$ & WODU & Aix sponsa & 0 & & & \\
\hline Northern Bobwhite ${ }^{\mathrm{a}, \mathrm{e}}$ & NOBO & Colinus virginianus & 1 & & & \\
\hline Ruffed Grouse ${ }^{\mathrm{a}, \mathrm{e}}$ & RUGR & Bonasa umbellus & 9 & & & \\
\hline Wild Turkey ${ }^{\mathrm{f}}$ & WITU & Meleagris gallopavo & 1 & & & \\
\hline Mourning Dove & MODO & Zanaida macroura & 24 & $\mathrm{X}$ & $\mathrm{X}$ & \\
\hline $\begin{array}{l}\text { Yellow-billed } \\
\text { Cuckoo }\end{array}$ & YBCU & Coccyzus americanus & 15 & $X$ & $\mathrm{X}$ & \\
\hline $\begin{array}{l}\text { Black-billed } \\
\text { Cuckoo }^{\mathrm{a}, \mathrm{d}, \mathrm{h}}\end{array}$ & BBCU & $\begin{array}{l}\text { Coccyzus } \\
\text { erythropthalmus }\end{array}$ & 21 & $\mathrm{X}$ & & \\
\hline Common Nighthawk ${ }^{\mathrm{a}}$ & CONI & Chordeiles minor & 0 & & & \\
\hline Chimney Swift ${ }^{\mathrm{a}, \mathrm{d}}$ & CHSW & Chaetura pelagica & 1 & & & \\
\hline $\begin{array}{l}\text { Ruby-throated } \\
\text { Hummingbird }\end{array}$ & RTHU & Archilochus colubris & 17 & & & \\
\hline Killdeer & KILL & Charadrius vociferus & 0 & & & \\
\hline $\begin{array}{l}\text { American } \\
\text { Woodcock }\end{array}$ & AMWO & Scolopax minor & 0 & & & \\
\hline Great Blue Heron ${ }^{b}$ & GBHE & Ardea herodias & 0 & & & \\
\hline Green Heron ${ }^{\mathrm{b}}$ & GRHE & Butorides virescens & 0 & & & \\
\hline Turkey Vulture & TUVU & Cathartes aura & 0 & & & \\
\hline Northern Harrier ${ }^{\mathrm{b}, \mathrm{e}}$ & NOHA & Circus cyaneus & 0 & & & \\
\hline Sharp-shinned Hawk ${ }^{\mathrm{e}}$ & SSHA & Accipiter striatus & 0 & & & \\
\hline Cooper's Hawk & СOHA & Accipiter cooperii & 0 & & & \\
\hline $\begin{array}{l}\text { Red-shouldered } \\
\text { Hawk }\end{array}$ & RSHA & Buteo lineatus & 0 & & & \\
\hline $\begin{array}{l}\text { Broad-winged } \\
\text { Hawk }^{\mathrm{a}, \mathrm{e}}\end{array}$ & BWHA & Buteo platypterus & 0 & & & \\
\hline Red-tailed Hawk & RTHA & Buteo jamaicensis & 2 & & & \\
\hline Great Horned Owl & GHOW & Bubo virginianus & 0 & & & \\
\hline Barred Owl & BADO & Strix varia & 0 & & & \\
\hline Belted Kingfisher & BEKI & Megaceryle alcyon & 1 & & & \\
\hline $\begin{array}{l}\text { Red-headed } \\
\text { Woodpecker }{ }^{\text {be,h }}\end{array}$ & RHWO & $\begin{array}{l}\text { Melanerpes } \\
\text { erythrocephalus }\end{array}$ & 0 & & & \\
\hline $\begin{array}{l}\text { Red-bellied } \\
\text { Woodpecker }\end{array}$ & RBWO & Melanerpes carolinus & 3 & & & \\
\hline $\begin{array}{l}\text { Yellow-bellied } \\
\text { Sapsucker }\end{array}$ & YBSA & Sphyrapicus varius & 2 & & & \\
\hline Downy Woodpecker & DOWO & Picoides pubescens & 3 & & & \\
\hline Hairy Woodpecker & HAWO & Picoides villosus & 4 & & & \\
\hline Northern Flicker & NOFL & Colaptes auratus & 3 & & & \\
\hline Pileated Woodpecker & PIWO & Dryocopus pileatus & 2 & & & \\
\hline American Kestrela & AMKE & Falco sparverius & 1 & & & \\
\hline
\end{tabular}




\begin{tabular}{|c|c|c|c|c|c|c|}
\hline Common name & Abbr. & Scientific name & $\begin{array}{c}\text { \% male } \\
\text { occurrence }\end{array}$ & $\begin{array}{l}1.5-\mathrm{km} \\
\text { minimum } \\
\text { elevation }\end{array}$ & $\begin{array}{l}100-\mathrm{m} \\
\text { minimum } \\
\text { elevation }\end{array}$ & $\begin{array}{c}100-\mathrm{m} \\
\text { shrubland } \\
\text { cover }\end{array}$ \\
\hline $\begin{array}{l}\text { Olive-sided } \\
\text { Flycatcher }{ }^{\mathrm{a}, \mathrm{e}, \mathrm{h}}\end{array}$ & OSFL & Contopus cooperi & 0 & & & \\
\hline Eastern Wood-pewee ${ }^{e}$ & EAWP & Contopus virens & 44 & $X$ & $\mathrm{X}$ & \\
\hline Acadian Flycatcher ${ }^{\mathrm{d}}$ & ACFL & Empidonax virescens & 20 & $\mathrm{X}$ & $\mathrm{X}$ & \\
\hline Alder Flycatcher ${ }^{\mathrm{b}, \mathrm{f}}$ & ALFL & Empidonax alnorum & 11 & & & $\mathrm{X}$ \\
\hline Willow Flycatcher ${ }^{\mathrm{e}}$ & WIFL & Empidonax traillii & 5 & & & \\
\hline Least Flycatcher ${ }^{b}$ & LEFL & Empidonax minimus & 35 & $X$ & & $\mathrm{X}$ \\
\hline Eastern Phoebe & EAPH & Sayornis phoebe & 19 & $\mathrm{X}$ & $\mathrm{X}$ & \\
\hline $\begin{array}{l}\text { Great Crested } \\
\text { Flycatcher }\end{array}$ & GCFL & Myiarchus crinitus & 12 & $\mathrm{X}$ & $\mathrm{X}$ & \\
\hline Eastern Kingbird & EAKI & Tyrannus tyrannus & 1 & & & \\
\hline White-eyed Vireo & WEVI & Vireo griseus & 10 & $\mathrm{X}$ & $\mathrm{X}$ & $\mathrm{X}$ \\
\hline $\begin{array}{l}\text { Yellow-throated } \\
\text { Vireo }^{\mathrm{e}}\end{array}$ & YTVI & Vireo flavifrons & 11 & & $\mathrm{X}$ & \\
\hline Blue-headed Vireo & BHVI & Vireo solitarius & 44 & $\mathrm{X}$ & & \\
\hline Warbling Vireo & WAVI & Vireo gilvus & 2 & & & \\
\hline Red-eyed Vireo & REVI & Vireo olivaceus & 98 & $\mathrm{X}$ & $\mathrm{X}$ & \\
\hline Blue Jay & BLJA & Cyanocitta cristata & 0 & & & \\
\hline American Crow & AMCR & Corvus brachyrhynchos & 0 & & & \\
\hline Common Raven & CORA & Corvus corax & 0 & & & \\
\hline Tree Swallow & TRES & Tachycineta bicolor & 2 & & & \\
\hline $\begin{array}{l}\text { Northern Rough- } \\
\text { winged Swallow }\end{array}$ & NRWS & $\begin{array}{l}\text { Stelgidopteryx } \\
\text { serripennis }\end{array}$ & 0 & & & \\
\hline Barn Swallow & BARS & Hirundo rustica & 2 & & & \\
\hline $\begin{array}{l}\text { Black-capped } \\
\text { Chickadee }^{\mathrm{e}}\end{array}$ & $\mathrm{BCCH}$ & Poecile atricapillus & 55 & $\mathrm{X}$ & $\mathrm{X}$ & \\
\hline Tufted Titmouse & TUTI & Baeolophus inornatus & 59 & $\mathrm{X}$ & $\mathrm{X}$ & \\
\hline $\begin{array}{l}\text { Red-breasted } \\
\text { Nuthatch }\end{array}$ & RBNU & Sitta Canadensis & 0 & & & \\
\hline $\begin{array}{l}\text { White-breasted } \\
\text { Nuthatch }\end{array}$ & WBNU & Sitta carolinensis & 3 & & & \\
\hline Brown Creeper ${ }^{b}$ & BRCR & Certhia americana & 1 & & & \\
\hline House Wren & HOWR & Troglodytes aedon & 23 & $\mathrm{X}$ & $\mathrm{X}$ & \\
\hline Winter Wren & WIWR & Troglodytes hiemalis & 5 & & & \\
\hline Carolina Wren & CARW & $\begin{array}{l}\text { Thryothorus } \\
\text { ludovicianus }\end{array}$ & 12 & $\mathrm{X}$ & $\mathrm{X}$ & \\
\hline $\begin{array}{l}\text { Blue-gray } \\
\text { Gnatcatcher }\end{array}$ & BGGN & Polioptila caerulea & 20 & $\mathrm{X}$ & $\mathrm{X}$ & $\mathrm{X}$ \\
\hline $\begin{array}{l}\text { Golden-crowned } \\
\text { Kinglet }\end{array}$ & GCKI & Regulus satrapa & 18 & $\mathrm{X}$ & & \\
\hline $\begin{array}{l}\text { Ruby-crowned } \\
\text { Kinglet }\end{array}$ & RCKI & Regulus calendula & 2 & & & \\
\hline Eastern Bluebird & EABL & Sialia sialis & 22 & $\mathrm{X}$ & $\mathrm{X}$ & \\
\hline Veery ${ }^{b}$ & VEER & Catharus fuscescens & 31 & $X$ & & \\
\hline Swainson's Thrush ${ }^{\mathrm{b}}$ & SWTH & Catharus ustulatus & 4 & & & \\
\hline Hermit Thrush & HETH & Catharus guttatus & 8 & & & \\
\hline Wood Thrusha,c,h & WOTH & Hylocichla mustelina & 35 & $\mathrm{X}$ & $X$ & \\
\hline American Robin & AMRO & Turdus migratorius & 51 & $\mathrm{X}$ & & $\mathrm{X}$ \\
\hline Gray Catbird & GRCA & Dumetella carolinensis & 57 & $\mathrm{X}$ & $\mathrm{X}$ & $\mathrm{X}$ \\
\hline Brown Thrashere & BRTH & Toxostoma rufum & 33 & $\mathrm{X}$ & $\mathrm{X}$ & $X$ \\
\hline $\begin{array}{l}\text { Northern } \\
\text { Mockingbird }\end{array}$ & NOMO & Mimus polyglottos & 3 & & & \\
\hline European Starling & EUST & Sturnus vulgaris & 2 & & & \\
\hline
\end{tabular}




\begin{tabular}{|c|c|c|c|c|c|c|}
\hline Common name & Abbr. & Scientific name & $\begin{array}{c}\text { \% male } \\
\text { occurrence }\end{array}$ & $\begin{array}{l}1.5-\mathrm{km} \\
\text { minimum } \\
\text { elevation }\end{array}$ & $\begin{array}{l}100-\mathrm{m} \\
\text { minimum } \\
\text { elevation }\end{array}$ & $\begin{array}{c}100-\mathrm{m} \\
\text { shrubland } \\
\text { cover }\end{array}$ \\
\hline Cedar Waxwing & CEDW & Bombycilla cedrorum & 9 & & & \\
\hline House Finch & HOFI & Haemorhous mexicanus & 1 & & & \\
\hline Purple Finch & PUFI & Haemorhous purpureus & 1 & & & \\
\hline Red Crossbill ${ }^{\mathrm{b}, \mathrm{d}}$ & RECR & Loxia curvirostra & 0 & & & \\
\hline American Goldfinch & AMGO & Spinus tristis & 54 & & & \\
\hline Eastern Towhee $\mathrm{e}^{\mathrm{e}}$ & EATO & Pipilo erythrophthalmus & 88 & $\mathrm{X}$ & & $\mathrm{X}$ \\
\hline Chipping Sparrow & CHSP & Spizella passerina & 49 & $\mathrm{X}$ & & \\
\hline $\begin{array}{l}\text { Clay-colored } \\
\text { Sparrow }\end{array}$ & CCSP & Spizella pallida & 0 & & & \\
\hline Field Sparrowa,d & FISP & Spizella pusilla & 65 & $\mathrm{X}$ & & $\mathrm{X}$ \\
\hline Vesper Sparrowa & VESP & Pooecetes gramineus & 7 & & & \\
\hline Savannah Sparrow & SAVS & $\begin{array}{l}\text { Passerculus } \\
\text { sandwichensis }\end{array}$ & 3 & & & \\
\hline $\begin{array}{l}\text { Grasshopper } \\
\text { Sparrow }^{a, e}\end{array}$ & GRSP & $\begin{array}{c}\text { Ammodramus } \\
\text { savannarum }\end{array}$ & 1 & & & \\
\hline Song Sparrow & SOSP & Melospiza melodia & 43 & $\mathrm{X}$ & $\mathrm{X}$ & \\
\hline Swamp Sparrow & SWSP & Melospiza georgiana & 1 & & & \\
\hline $\begin{array}{l}\text { White-throated } \\
\text { Sparrowe }\end{array}$ & WTSP & Zonotrichia albicollis & 0 & & & \\
\hline Dark-eyed Junco & DEJU & Junco hyemalis & 33 & $\mathrm{X}$ & & \\
\hline $\begin{array}{l}\text { Yellow-breasted } \\
\text { Chat }^{\mathrm{a}, \mathrm{e}}\end{array}$ & $\mathrm{YBCH}$ & Icteria virens & 9 & & & \\
\hline Bobolink ${ }^{\mathrm{a}, \mathrm{h}}$ & ВОВО & Dolichonyx oryzivorus & 2 & & & \\
\hline $\begin{array}{l}\text { Eastern } \\
\text { Meadowlark }{ }^{\mathrm{a}, \mathrm{e}}\end{array}$ & EAME & Sturnella magna & 7 & & & \\
\hline Orchard Oriole & OROR & Icterus spurius & 1 & & & \\
\hline Baltimore Oriole & BAOR & Icterus galbula & 21 & & $\mathrm{X}$ & \\
\hline $\begin{array}{l}\text { Red-winged } \\
\text { Blackbird }\end{array}$ & RWBL & Agelaius phoeniceus & 16 & $\mathrm{X}$ & $\mathrm{X}$ & \\
\hline $\begin{array}{l}\text { Brown-headed } \\
\text { Cowbird }\end{array}$ & $\mathrm{BHCO}$ & Molothrus ater & 32 & $\mathrm{X}$ & $\mathrm{X}$ & \\
\hline Common Grackle & COGR & Quiscalus quiscula & 3 & & & \\
\hline Ovenbird & OVEN & Seiurus aurocapilla & 48 & $\mathrm{X}$ & & \\
\hline $\begin{array}{l}\text { Worm-eating } \\
\text { Warblera,c }\end{array}$ & WEWA & Helmitheros vermivorum & 3 & & & \\
\hline $\begin{array}{l}\text { Louisiana } \\
\text { Waterthrush }{ }^{\mathrm{a}, \mathrm{d}}\end{array}$ & LOWA & Parkesia motacilla & 3 & & & \\
\hline $\begin{array}{l}\text { Golden-winged } \\
\text { Warbler }^{\mathrm{a}, \mathrm{c}, \mathrm{g}}\end{array}$ & GWWA & Vermivora chrysoptera & 26 & $\mathrm{X}$ & $\mathrm{X}$ & $\mathrm{X}$ \\
\hline $\begin{array}{l}\text { Blue-winged } \\
\text { Warblerb,c }\end{array}$ & BWWA & Vermivora cyanoptera & 10 & & $\mathrm{X}$ & \\
\hline Brewster's Warbler & BRWA & $\begin{array}{l}\text { Vermivora chrysoptera x } \\
\text { cyanoptera }\end{array}$ & 6 & & & \\
\hline Lawrence's Warbler & LAWA & $\begin{array}{l}\text { Vermivora chrysoptera x } \\
\text { cyanoptera }\end{array}$ & 0 & & & \\
\hline $\begin{array}{l}\text { Black-and-white } \\
\text { Warblere }\end{array}$ & BAWW & Mniotilta varia & 46 & $\mathrm{X}$ & $\mathrm{X}$ & \\
\hline Tennessee Warbler & TEWA & Oreothlypis peregrina & 2 & & & \\
\hline Mourning Warbler & MOWA & Geothlypis philadelphia & 27 & $\mathrm{X}$ & & \\
\hline Kentucky Warblera,c,h & KEWA & Geothlypis formosa & 2 & & & \\
\hline $\begin{array}{l}\text { Common } \\
\text { Yellowthroat }\end{array}$ & COYE & Geothlypis trichas & 66 & $\mathrm{X}$ & & $\mathrm{X}$ \\
\hline Hooded Warbler ${ }^{\mathrm{d}}$ & HOWA & Setophaga citrina & 41 & $\mathrm{X}$ & $\mathrm{X}$ & \\
\hline
\end{tabular}




\begin{tabular}{|c|c|c|c|c|c|c|}
\hline Common name & Abbr. & Scientific name & $\begin{array}{c}\text { \% male } \\
\text { occurrence }\end{array}$ & $\begin{array}{c}1.5-\mathrm{km} \\
\text { minimum } \\
\text { elevation }\end{array}$ & $\begin{array}{c}100-m \\
\text { minimum } \\
\text { elevation }\end{array}$ & $\begin{array}{c}100-\mathrm{m} \\
\text { shrubland } \\
\text { cover }\end{array}$ \\
\hline American Redstart & AMRE & Setophaga ruticilla & 57 & $\mathrm{X}$ & $\mathrm{X}$ & \\
\hline Cerulean Warbler ${ }^{\mathrm{a}, \mathrm{c}, \mathrm{h}}$ & CERW & Setophaga cerulea & 9 & & & \\
\hline Northern Parula ${ }^{e}$ & NOPA & Setophaga americana & 10 & & & \\
\hline Magnolia Warbler & MAWA & Setophaga magnolia & 29 & $\mathrm{X}$ & & \\
\hline $\begin{array}{l}\text { Bay-breasted } \\
\text { Warbler }^{\mathrm{e}}\end{array}$ & BBWA & Setophaga castanea & 1 & & & \\
\hline $\begin{array}{l}\text { Blackburnian } \\
\text { Warbler }{ }^{b, e}\end{array}$ & BLBW & Setophaga fusca & 35 & $X$ & & \\
\hline Yellow Warbler & YEWA & Setophaga petechia & 25 & $\mathrm{X}$ & $\mathrm{X}$ & $\mathrm{X}$ \\
\hline $\begin{array}{l}\text { Chestnut-sided } \\
\text { Warbler }\end{array}$ & CSWA & Setophaga pensylvanica & 85 & $\mathrm{X}$ & & \\
\hline Blackpoll Warbler ${ }^{\mathrm{f}}$ & BLPW & Setophaga striata & 7 & & & \\
\hline $\begin{array}{l}\text { Black-throated Blue } \\
\text { Warblerb }\end{array}$ & BTBW & Setophaga caerulescens & 22 & $X$ & & \\
\hline Pine Warbler & PIWA & Setophaga pinus & 2 & & & \\
\hline $\begin{array}{l}\text { Yellow-rumped } \\
\text { Warbler }\end{array}$ & YRWA & Setophaga coronata & 3 & & & \\
\hline $\begin{array}{l}\text { Yellow-throated } \\
\text { Warblere }\end{array}$ & YTWA & Setophaga dominica & 2 & & & \\
\hline Prairie Warbler ${ }^{\mathrm{a}, \mathrm{ch}}$ & PRAW & Setophaga discolor & 2 & & & \\
\hline $\begin{array}{l}\text { Black-throated Green } \\
\text { Warbler }\end{array}$ & BTNW & Setophaga virens & 53 & $\mathrm{X}$ & & \\
\hline Canada Warbler ${ }^{\mathrm{a}, \mathrm{d}, \mathrm{h}}$ & CAWA & Cardellina canadensis & 7 & & & \\
\hline Scarlet Tanager ${ }^{\mathrm{e}}$ & SCTA & Piranga olivacea & 69 & $\mathrm{X}$ & $\mathrm{X}$ & \\
\hline Northern Cardinal & NOCA & Cardinalis cardinalis & 41 & $\mathrm{X}$ & $\mathrm{X}$ & \\
\hline $\begin{array}{l}\text { Rose-breasted } \\
\text { Grosbeak }\end{array}$ & RBGR & Pheucticus ludovicianus & 41 & $\mathrm{X}$ & & $X$ \\
\hline Indigo Buntinge & INBU & Passerina cyanea & 95 & $\mathrm{X}$ & & \\
\hline
\end{tabular}

${ }^{a}$ Priority 1 (West Virginia Division of Natural Resources 2015)

b Priority 2 (West Virginia Division of Natural Resources 2015)

${ }^{\text {c }}$ Highest priority (Appalachian Mountains Joint Venture Management Board 2008)

${ }^{\mathrm{d}}$ High priority (Appalachian Mountains Joint Venture Management Board 2008)

e Moderate priority (Appalachian Mountains Joint Venture Management Board 2008)

${ }^{\mathrm{f}}$ Low priority (Appalachian Mountains Joint Venture Management Board 2008)

g Red Watch List: species with extremely high vulnerability due to small population and range, high threats, and rangewide declines (Rosenberg et al. 2016b)

h "D” Yellow Watch List: species with population declines and moderate to high threats (Rosenberg et al. 2016b) 


\section{FIGURES}

\section{A. Overview}
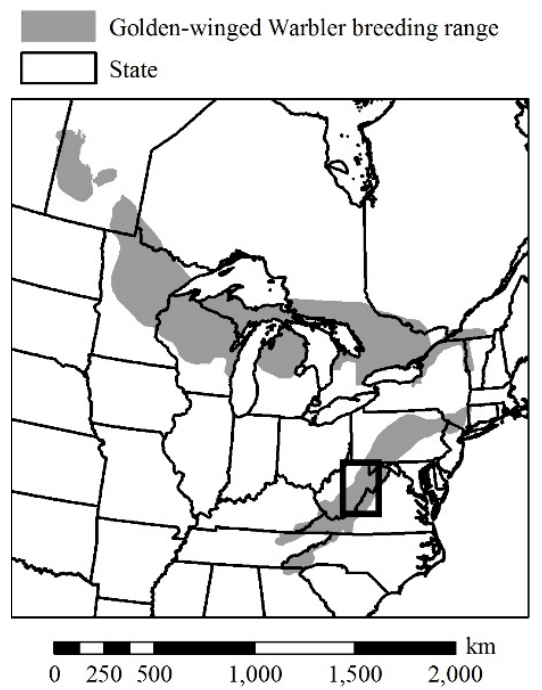

B. Study area

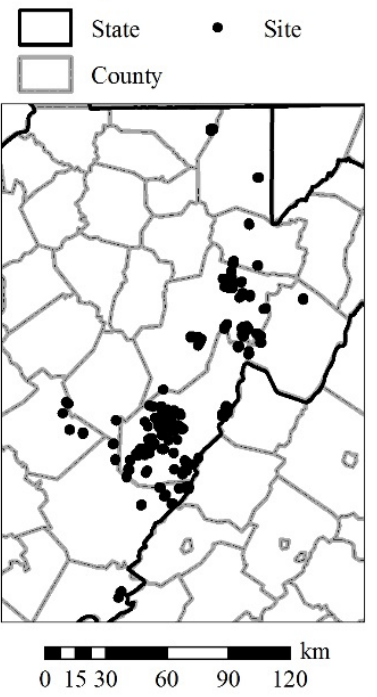

C. Example site

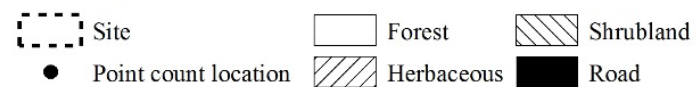

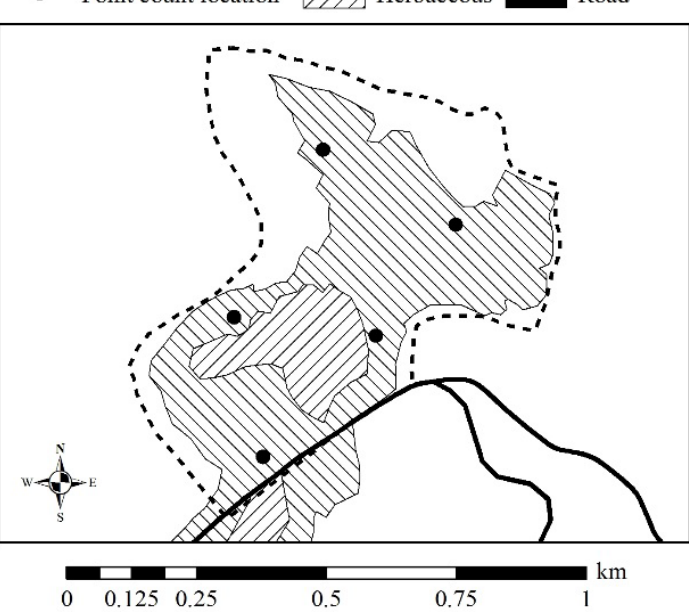

Figure 1. Within the Golden-winged Warbler's contemporary breeding range in West Virginia (A; Roth et al. 2012), we surveyed sites (B, $n=121$ ) with 10-min, 100-m radius avian point counts ( $\mathbf{C}, n=273$ unique point count locations, $n=1,096$ point counts) during May-June 2008-2015. 


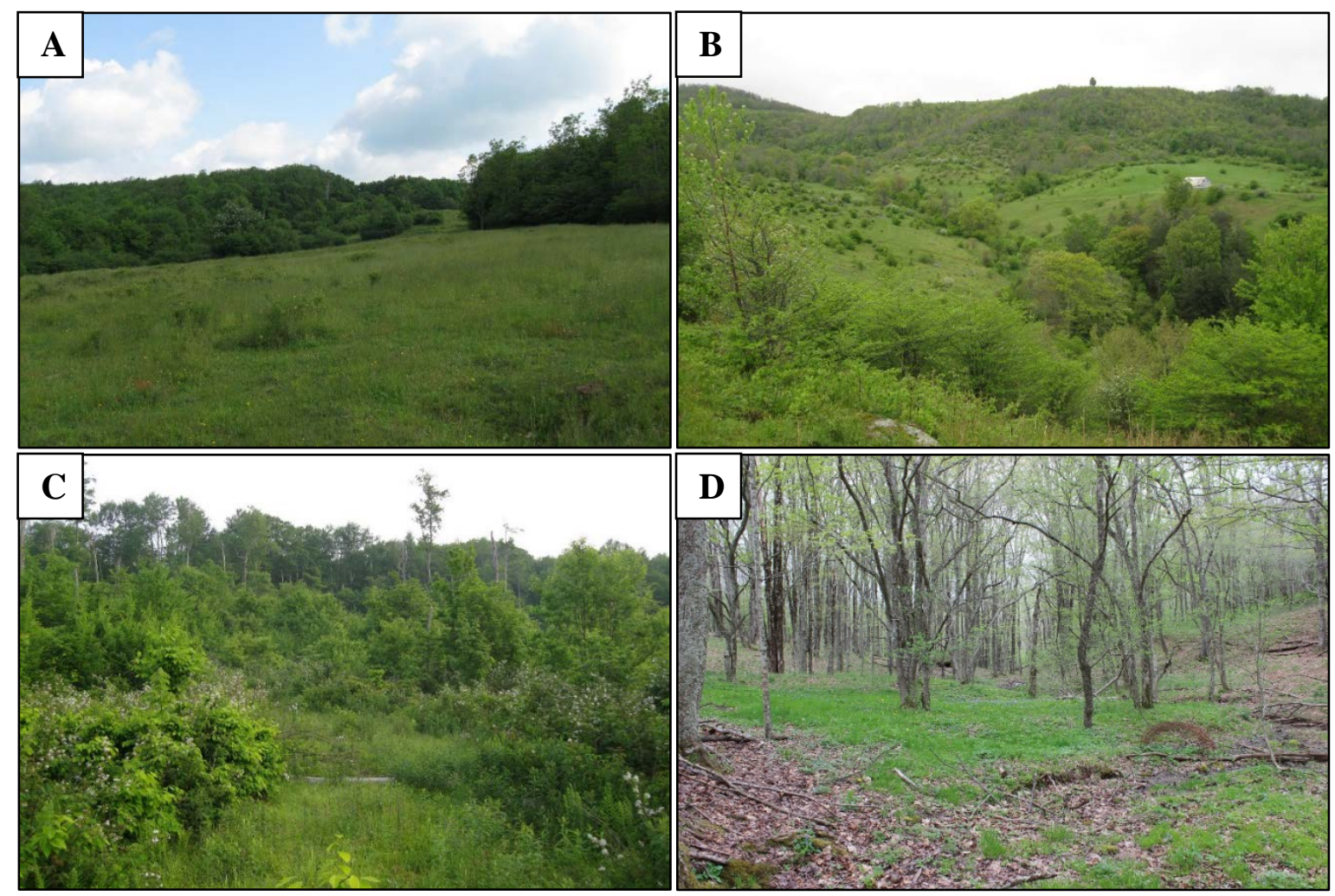

Figure 2. We sampled a successional gradient ranging from (A) herbaceous to (B) shrubland to (C) young forest to (D) later successional forest vegetation communities. Vegetative conditions varied widely among point count locations $(n=273)$ at the $100-\mathrm{m}$ scale due to varied management regimes among sites $(n=121)$. 

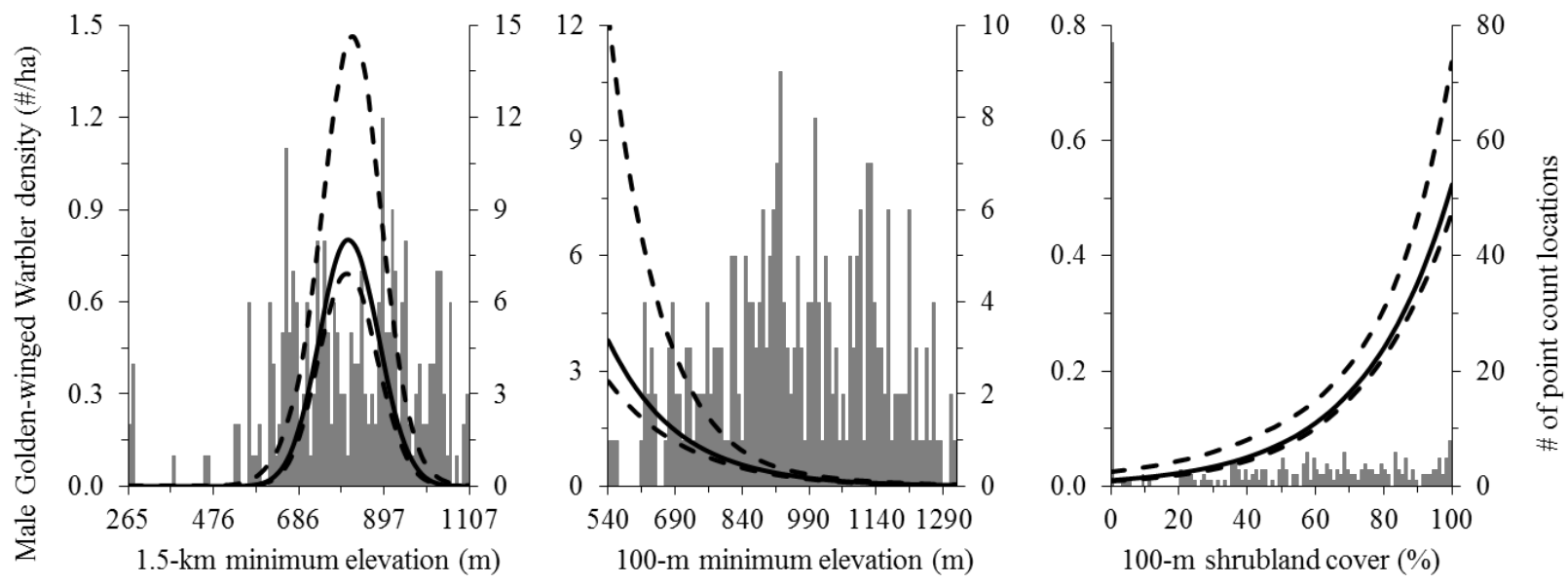

Figure 3. Median marginal predicted male Golden-winged Warbler density (solid line) and 95\% quantile confidence interval (dashed lines). Predictions are based on the top density model including fixed effects for 1.5-km minimum elevation, $100-\mathrm{m}$ minimum elevation, and 100-m shrubland cover and random effects for point count location ID, site, and year (Table 4). Gray bars represent \# of point count locations sampled. See Table 2 for covariate descriptions. 


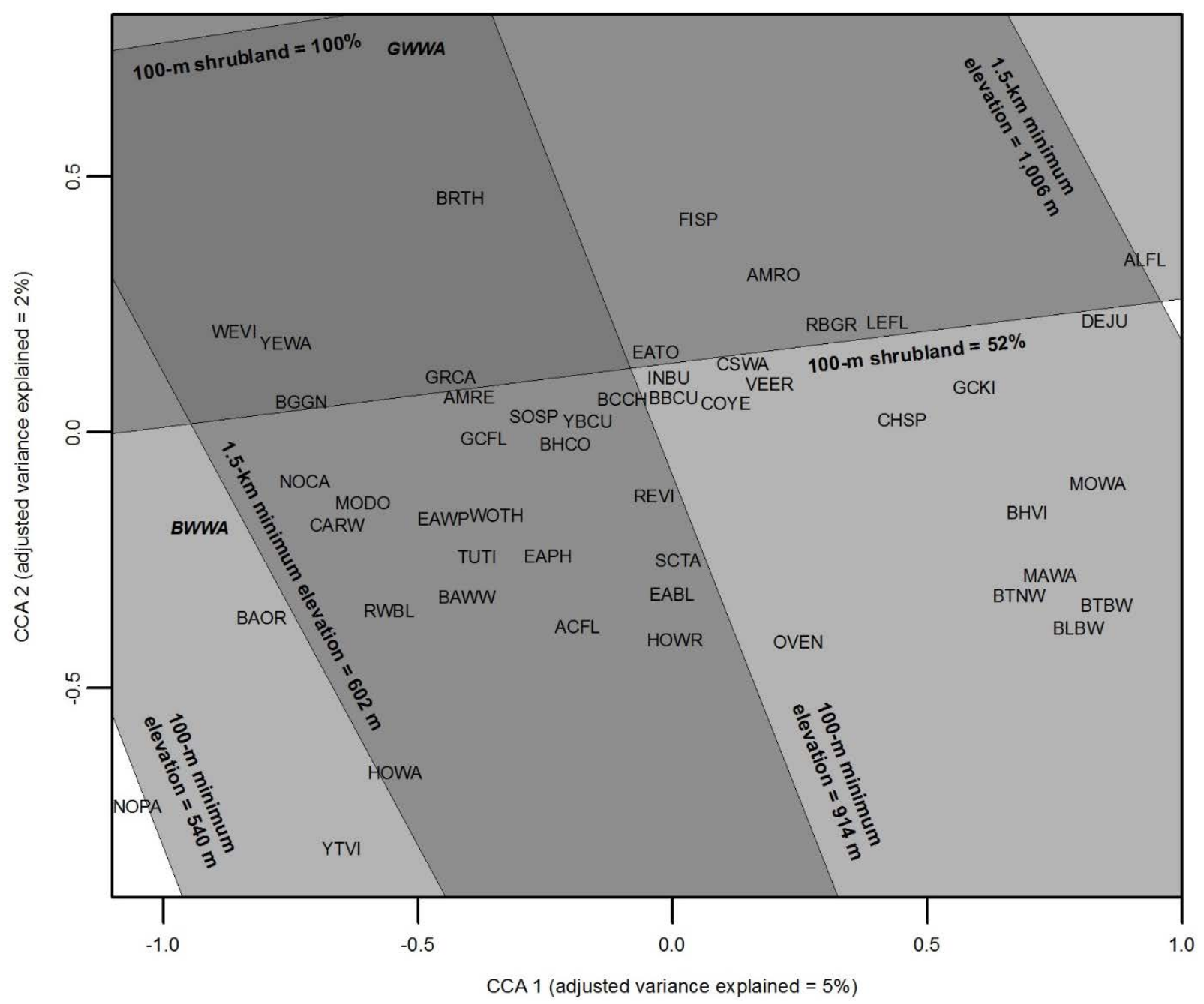

Figure 4. Canonical correspondence analysis results for species within the ranges of fitted covariate surface values predicted to be associated with greater than median densities of Goldenwinged Warbler (Figure 5: 100-m shrubland cover $=52-100 \%, 100-\mathrm{m}$ minimum elevation $=$ 540-914 m, 1.5-km minimum elevation = 602-1,006 m). Blue-winged Warbler (BWWA bold italics) is highlighted because the species hybridizes with Golden-winged Warbler. Darker shading represents overlapping covariate ranges. See Table 5 for species abbreviations. 

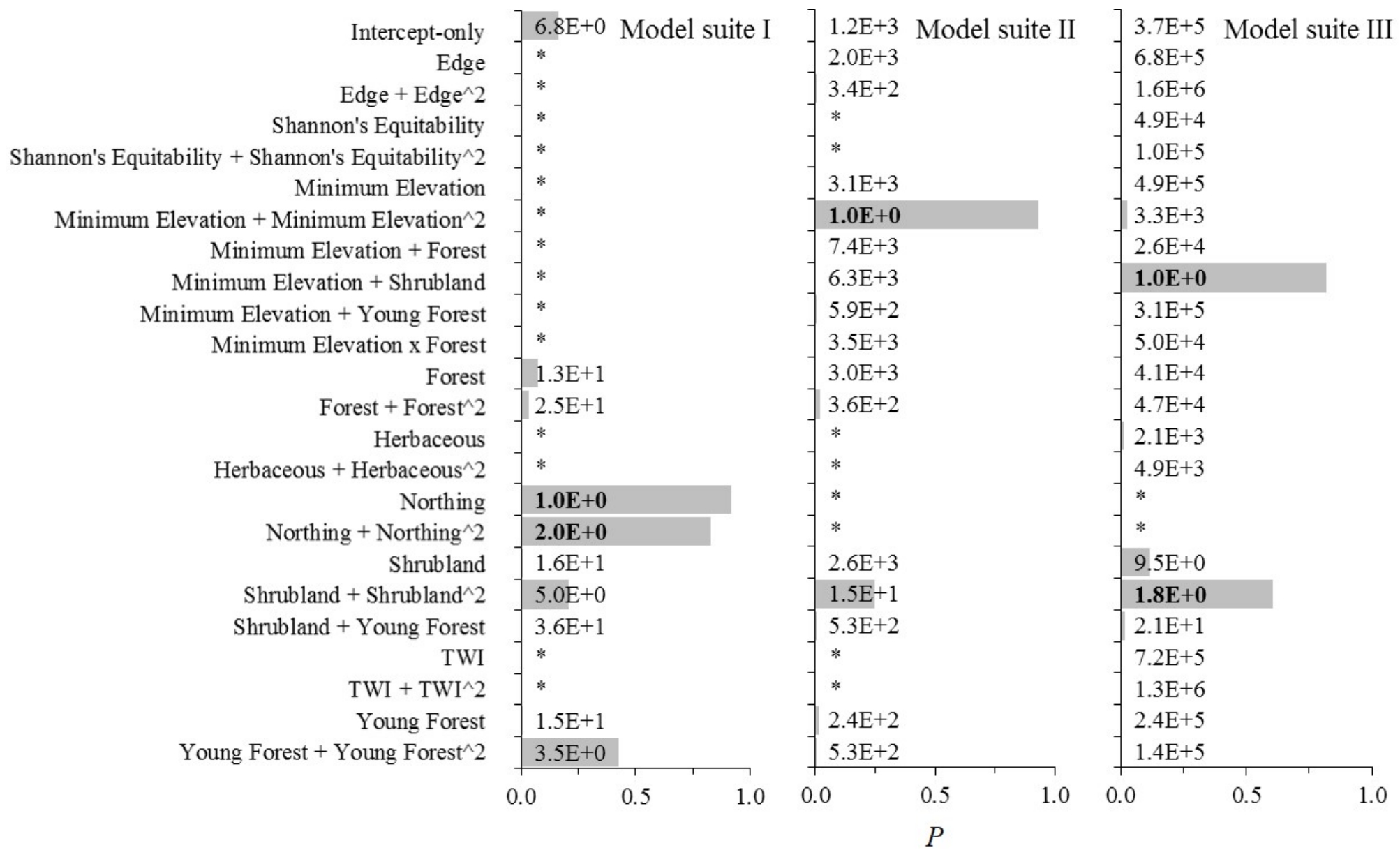

Figure 5. We used AIC (Burnham and Anderson 2002) to compare among candidate Golden-winged Warbler density models for model suites I (5-km geospatial covariates: annual dispersal scale), II (1.5-km geospatial covariates: extra-territorial movement scale), and III (100-m geospatial covariates: intra-territorial movement scale). We calculated the evidence ratio ( $\mathrm{E}=\mathrm{e} 0.5 \Delta \mathrm{AIC}$, where $\Delta \mathrm{AIC}$ is the AIC value of the candidate model minus the minimum AIC value in the model suite) for each model in each bootstrap replicate ( $\mathrm{n}=1,000$ replicates). $\mathrm{M}$ is the proportion of bootstrap replicates when $\mathrm{E} \leq 2.7$ (gray bars). Data labels represent median $\mathrm{E}$ across all bootstrap replicates. Models with median E $\leq 2.7$ (bold labels) were considered plausible. All models had random intercepts for year and for point count ID nested within site. Asterisks denote models not included in the model suite. See Table 2 for covariate descriptions (TWI = topographic wetness index). 


$$
\begin{aligned}
& \text { Vegetation Density }+ \text { Grass }+ \text { Forb }] 3.3 \mathrm{E}+0 \\
& \text { Sapling + Sapling^2 } 7.6 \mathrm{E}+0 \\
& \text { Vegetation Density }+ \text { Vegetation Density }{ }^{\wedge} 2.6 \mathrm{E}+0 \\
& \text { Vegetation Density } 6.9 \mathrm{E}+0 \\
& \text { Sapling } 1.3 \mathrm{E}+1 \\
& \text { Shrub }+\mathrm{Shrub}^{\wedge} 2.3 \mathrm{E}+1 \\
& \text { Rubus + Shrub + Sapling } 3.2 \mathrm{E}+1 \\
& \text { Rubus + Rubus`2 } 6.3 \mathrm{E}+1 \\
& \text { Rubus } 6.5 \mathrm{E}+1 \\
& \text { Shrub Height } \left.+ \text { Shrub Height }{ }^{\wedge} 2\right] 1.3 \mathrm{E}+2 \\
& \text { Canopy } 8.6 \mathrm{E}+1 \\
& \text { Sapling Height }+ \text { Sapling Height }{ }^{\wedge} 21.2 \mathrm{E}+2 \\
& \text { Grass }+ \text { Forb + Vine + Rubus + Shrub + Sapling 9.2E+1 } \\
& \text { Canopy }+ \text { Canopy^2 } 1.8 \mathrm{E}+2 \\
& \text { Shrub Height } 1.8 \mathrm{E}+2 \\
& \text { Vine + Vine }{ }^{\wedge} 2.3 \mathrm{E}+2 \\
& \text { Basal Area`2 } 3.1 \mathrm{E}+2 \\
& \text { Vine } 1.4 \mathrm{E}+2 \\
& \text { Intercept-Only } 1.1 \mathrm{E}+2 \\
& \text { Grass } 1.1 \mathrm{E}+2 \\
& \text { Grass }+ \text { Grass }^{\wedge} 21.8 \mathrm{E}+2 \\
& \text { Basal Area } 2.2 \mathrm{E}+2 \\
& \text { Forb } 2.1 \mathrm{E}+2 \\
& \text { Forb }+ \text { Forb }^{\wedge} 2 \text { 4.4E+2 } \\
& \text { Grass + Forb } 2.2 \mathrm{E}+2 \\
& \text { Shrub Height }+ \text { Sapling Height } 3.2 \mathrm{E}+2 \\
& \text { Sapling Height } 1.9 \mathrm{E}+2 \\
& \text { Shrub } 2.0 \mathrm{E}+2 \\
& \begin{array}{lll}
0.0 & 0.5 & 1.0
\end{array} \\
& P
\end{aligned}
$$

Figure 6. We used AIC (Burnham and Anderson 2002) to compare among candidate Goldenwinged Warbler density models in model suite IV (field vegetation covariates: local resource utilization scale). We calculated the evidence ratio $\left(E=e^{0.5 \Delta A I C}\right.$, where $\triangle \mathrm{AIC}$ is the AIC value of the candidate model minus the minimum AIC value in the model suite) for each model in each bootstrap replicate ( $\mathrm{n}=1,000$ replicates). $M$ is the proportion of bootstrap replicates when $E \leq 2.7$ (gray bars). Data labels represent median $E$ across all bootstrap replicates. No models were considered plausible (all median $E>2.7$ ). All models had random intercepts for year and for point count ID nested within site. See Table 2 for covariate descriptions. 
1.5-km Minimum Elevation + 1.5-km Minimum Elevation^2 $+100-\mathrm{m}$ Shrubland + 100-m Minimum Elevation

Northing + 1.5-km Minimum Elevation + 1.5-km Minimum Elevation^2 + 100-m Shrubland + 100-m Minimum Elevation

Northing + Northing $` 2+1.5-\mathrm{km}$ Minimum Elevation $+1.5-\mathrm{km}^{\wedge}$ Minimum Elevation^ $2+100-\mathrm{m}$ Shrubland $+100-\mathrm{m}$ Minimum Elevation 1.5-km Minimum Elevation + 1.5-km Minimum Elevation^2 $+100-\mathrm{m}$ Shrubland $+100-\mathrm{m}$ Shrubland^2

Northing + 1.5-km Minimum Elevation + 1.5-km Minimum Elevation^² + 100-m Shrubland + 100-m Shrubland`2 Northing + Northing ${ }^{\wedge} 2+1.5-\mathrm{km}$ Minimum Elevation $+1.5-\mathrm{km}$ Minimum Elevation^ $2+100-\mathrm{m}$ Shrubland $+100-\mathrm{m}$ Shrubland 2

Northing + Northing^ $2+100-\mathrm{m}$ Shrubland $+100-\mathrm{m}$ Minimum Elevation

100-m Minimum Elevation + 100-m Shrubland Northing + Northing $^{\wedge} 2+100-\mathrm{m}$ Shrubland $+100-\mathrm{m}$ Shrubland ${ }^{\wedge} 2$

Northing + 100-m Shrubland + 100-m Minimum Elevation

Northing $+100-\mathrm{m}$ Shrubland $+100-\mathrm{m}$ Shrubland ${ }^{\wedge} 2$

100-m Shrubland + 100-m Shrubland^2

1.5-km Minimum Elevation + 1.5-km Minimum Elevation^2

Northing + 1.5-km Minimum Elevation + 1.5-km Minimum Elevation^2

Northing + Northing $` 2+1.5-\mathrm{km}$ Minimum Elevation $+1.5-\mathrm{km}$ Minimum Elevation ${ }^{\wedge} 2$

Northing

Northing + Northing ${ }^{\wedge} 2$

Intercept-only

\begin{tabular}{|r}
$1.0 \mathrm{E}+0$ \\
$2.5 \mathrm{E}+0$ \\
$5.3 \mathrm{E}+0$ \\
$1.6 \mathrm{E}+2$ \\
$1.5 \mathrm{E}+2$ \\
$2.7 \mathrm{E}+2$ \\
$1.2 \mathrm{E}+4$ \\
$6.5 \mathrm{E}+4$ \\
$1.1 \mathrm{E}+5$ \\
$6.7 \mathrm{E}+3$ \\
$6.8 \mathrm{E}+4$ \\
$1.3 \mathrm{E}+5$ \\
$1.9 \mathrm{E}+7$ \\
$3.8 \mathrm{E}+7$ \\
$5.5 \mathrm{E}+7$ \\
$3.6 \mathrm{E}+9$ \\
$5.6 \mathrm{E}+9$ \\
$2.4 \mathrm{E}+10$ \\
\hline 0 \\
0.5 \\
$P$
\end{tabular}

Figure 7. We used AIC (Burnham and Anderson 2002) to compare among candidate Golden-winged Warbler density models in model suite $\mathrm{V}$, which featured all possible combinations of plausible models from model suites I-IV (Figures 2-3). We calculated the evidence ratio $\left(E=e^{0.5 \triangle A I C}\right.$, where $\triangle \mathrm{AIC}$ is the AIC value of the candidate model minus the minimum AIC value in the model suite) for each model in each bootstrap replicate ( $\mathrm{n}=1,000$ replicates). $M$ is the proportion of bootstrap replicates when $E \leq 2.7$ (gray bars). Data labels represent median $E$ across all bootstrap replicates. Models with median $E \leq 2.7$ (bold labels) were considered plausible. All models had random intercepts for year and for point count ID nested within site. Asterisks denote models not included in the model suite. See Table 2 for covariate descriptions. 


\title{
CHAPTER 3. MINIMALLY-BIASED ESTIMATES OF ANNUAL SURVIVAL AND DISPERSAL FOR BREEDING VERMIVORA WARBLERS IN WEST VIRGINIA
}

\author{
ABSTRACT \\ Bias-corrected estimates of annual survival and dispersal, which are key components of \\ population dynamics for migratory birds and have important conservation implications, have not \\ been attempted for Golden-winged Warblers (Vermivora chrysoptera). Therefore, our objective \\ was to use a spatial Cormack-Jolly-Seber (s-CJS) model to obtain minimally-biased estimates of \\ annual survival and breeding and natal dispersal for Golden-winged Warblers in West Virginia, \\ as well as for locally less abundant Blue-winged Warblers (V. cyanoptera) and their hybrids. \\ During 2008-2015, we banded and attempted to resight 517 Vermivora warblers across a study \\ area encompassing 3,150 ha of area searched. We modeled variation in survival by age, \\ phenotype, sex, and geographic location, dispersal by age, and detection probability by search \\ effort. We also summarized observed natal and breeding dispersal because of a dearth of \\ published data. Vermivora warbler annual survival did not vary by phenotype, sex, or study area, \\ but adult annual survival $(0.53$, 95\% confidence interval $[\mathrm{CI}]=0.46-0.60)$ was higher than \\ juvenile annual survival (0.09, 0.05-0.13). Adjusting for mortality during the post-fledging \\ period, juvenile annual survival may be about half of adult annual survival. Expected breeding \\ dispersal (329 m, 316-344 m) was less than expected natal dispersal (544 m, 500-592 m) based \\ on our s-CJS model. We observed the longest distances for natal dispersal (mean = 1,587 $\mathrm{m}$, \\ median $=1,047 \mathrm{~m}, \mathrm{n}=18$ ), intermediate distances for second year to after second year dispersal \\ ( mean $=492 \mathrm{~m}$, median $=132 \mathrm{~m}, \mathrm{n}=46$ ), and the shortest distances for after second year \\ dispersal (mean $\pm \mathrm{SE}=290 \mathrm{~m}$, median $=103 \mathrm{~m}, \mathrm{n}=103)$. Female $(716 \pm 162 \mathrm{~m}, \mathrm{n}=43)$ \\ warblers also tended to disperse farther than males $(404 \pm 64 \mathrm{~m}, \mathrm{n}=124)$. Age- and sex- \\ dependent dispersal information can enhance the spatial components of Golden-winged Warbler \\ management plans. Our results advance our understanding of Golden-winged Warbler ecology, \\ improve conservation efforts, and hopefully spur complementary research so that we may \\ validate findings about potential limiting factors during the species' annual cycle. \\ Keywords: apparent, bias, Blue-winged Warbler, Golden-winged Warbler, hybrid, mark- \\ recapture, shrubland, true
}




\section{INTRODUCTION}

Annual survival for migratory birds is the product of survival during geographicallydistinct breeding, migratory, and non-breeding periods of the annual cycle (Sillett and Holmes 2002, Faaborg et al. 2010, Rushing et al. 2016). Therefore, shrinking populations of migratory birds could be limited by survival during any one of these periods (Sherry and Holmes 1995). For migratory songbirds breeding in shrubland and young forest vegetation communities (hereafter, "shrublands”) in eastern North America, much emphasis has been placed on addressing potential limiting factors on the breeding grounds, such as habitat availability and quality (DeGraf and Yamasaki 2003, Dettmers 2003, Gifford et al. 2010, Akresh et al. 2015, Aldinger et al. 2017). Such emphasis is logical because the amount of shrubland cover in eastern North America is historically low and because shrubland-nesting birds face more pervasive declines than forest-nesting birds from the same geography (King and Schlossberg 2014, Sauer et al. 2017). However, recent evidence suggests even shrubland-nesting birds with limited amounts of breeding habitat in the landscape, such as Golden-winged Warblers (Vermivora chrysoptera), could be more limited by factors during the migratory and non-breeding periods than by factors during the breeding season (Kramer et al. 2018).

Kramer et al. (2018) provided strong evidence that migratory connectivity between breeding and non-breeding areas was associated with breeding population trends. More specifically, Golden-winged Warbler populations breeding in the Great Lakes region and wintering in Central America have been stable in size while populations breeding in the Appalachian Mountains region and wintering in northern South America have decreased dramatically. Populations of Blue-winged Warbler (Vermivora cyanoptera), the other member of the Vermivora species complex (Gill 2004, Toews et al. 2016), overlapped both Golden-winged Warbler breeding populations but wintered in Central America and maintained relatively stable population size. This suggests that Appalachian Mountains Golden-winged Warbler populations are limited by factors during the migratory or non-breeding periods. Still, the annual cycle of a widely-distributed migratory species is complex and myriad factors may be acting together to drive Golden-winged Warbler population declines (Kramer et al. 2018). For example, breeding Golden-winged and Blue-winged warblers generally segregate by elevation across much of the Appalachian Mountains region, suggesting that habitat availability at elevations $>500 \mathrm{~m}$ could be an important limiting factor unique to Appalachian Mountain Golden-winged Warbler 
populations (Welton 2003, Patton et al. 2010, Bakermans et al. 2015, Crawford et al. 2016, Aldinger et al. 2017). Therefore, an important next step is to build upon the results of Kramer et al. (2018) by directly measuring demographic rates in multiple areas across the species' breeding range to identify limiting factors in time and space.

Recent improvements over traditional Cormack-Jolly-Seber (CJS; Lebreton et al. 1992) survival models that use spatial location information associated with encounter histories provide just such an opportunity to estimate true annual survival of Golden-winged Warblers during the migratory and non-breeding periods (Schaub and Royle 2014). Traditional CJS models estimate apparent annual survival, which is biased low because annual survival and permanent emigration are confounded for animals with imperfect site fidelity. The new spatial CJS (s-JCS) models derive minimally-biased estimates of true survival by disentangling mortality and emigration. Banding and re-sighting data for s-CJS models could be collected from across the Goldenwinged Warbler's breeding range because of multi-year studies occurring in response to the species’ imperiled conservation status (Bulluck et al. 2013, Peterson et al. 2015, Frantz et al. 2016). In addition to validating Kramer et al. (2018), estimates of true annual survival may answer specific questions about different periods of the annual cycle. For example, if annual survival is similar among Great Lakes and Appalachian Mountains populations, then habitat availability at higher elevations in the latter region may be driving differences in population trends. Furthermore, minimally-biased survival estimates are needed to parameterize Goldenwinged Warbler full life-cycle models that will help to guide conservation efforts (Rohrbaugh et al. 2016). Finally, s-CJS models can reveal information about annual dispersal behavior, which is not described for Golden-winged Warblers except for anecdotal observations and descriptive data on breeding site fidelity (Confer et al. 2011, Bulluck et al. 2013, Peterson et al. 2015). Annual dispersal is a critical component of population dynamics and has implications for conservation planning (Cilimburg et al. 2002, Cline et al. 2013), presumably more so for species nesting in scarce, isolated, and ephemeral vegetation communities such as high-elevation shrublands in the Appalachian Mountains region.

The dispersal of migratory birds from their natal nest to their breeding site in a later year, referred to as natal dispersal, is an especiallypoorly understood type of dispersal (Schlossberg 2009). Studies of natal dispersal, and consequently survival, among migratory songbirds currently are hindered by the nature of dispersal behavior itself and technology. Natal philopatry 
for shrubland-nesting songbirds is 4.8\% (Schlossberg 2009) and for migratory songbirds nesting in isolated sites is 10.5\% (Weatherhead and Forbes 1994). Tracking devices are now small enough to be attached to hatch year songbirds for a year at a time, but must be retrieved later to download data (Streby et al. 2015). Birds that disperse beyond their natal site are rarely encountered (Anich et al. 2017). For Golden-winged Warblers, we are aware of only two studies that presented data on natal returns. In Michigan, $0 \%$ of banded nestlings $(n=88)$ were resighted in a later year (Will 1986). In Ontario and Tennessee, <10\% of banded nestlings were resighted in a later year (Bulluck et al. 2013). Therefore, much needed information can be gained from even a cursory examination of natal dispersal. Land cover composition across most of the Golden-winged Warbler's Appalachian Mountains breeding range is favorable for studying natal dispersal because shrubland cover is rare and isolated (Aldinger et al. 2017).

Our objective was to quantify survival and dispersal of Golden-winged Warblers in the Allegheny Mountains of West Virginia. We also included co-occurring but locally less abundant Blue-winged Warblers and Vermivora hybrids in our study. We used a s-CJS model to derive the first published estimates of true, rather than apparent, annual survival and dispersal for Goldenwinged Warblers. We were specifically interested in variation in survival by age, phenotype, sex, and geographic location. These results advance our understanding of Golden-winged Warbler ecology, improve conservation efforts, and hopefully spur similar research in other parts of the species' range so that we may validate recent findings about potential limiting factors during the species’annual cycle (Kramer et al. 2018).

\section{METHODS}

\section{Study Area}

During 2008-2015, we monitored shrubland vegetation communities in Greenbrier, Monongalia, Monroe, Nicholas, Pendleton, Pocahontas, Preston, Randolph, Tucker, and Webster counties within the Central Appalachian and Ridge and Valley level III ecoregions of West Virginia (Omernik and Griffith 2014). Above 500 m within the Golden-winged Warbler’s contemporary breeding range (Roth et al. 2012, Crawford et al. 2016), West Virginia is 87\% forested with only 4\% in shrubland, which are used by nesting Golden-winged Warblers (West Virginia GIS Technical Center 2012, Aldinger et al. 2017). Shrublands in our study area primarily result from localized anthropogenic disturbances such as livestock grazing, timber 
harvesting, mechanical cutting (e.g., mowing or brush-hogging), and surface mining (Aldinger et al. 2017). Consequently, individual contiguous shrubland patches generally are relatively small (mean \pm standard error $[\mathrm{SE}]=2.3 \pm 0.1 \mathrm{ha}$ ) and surrounded by closed-canopy later-successional forest (Aldinger et al. 2017). The relative scarcity and discreteness of patches of nesting cover make West Virginia logistically a favorable location to monitor Golden-winged Warbler annual dispersal because individuals are readily located within patches accessible by observers.

In this study, we defined a site as a discrete area with a single management regime resulting in vegetative structure and composition that were relatively uniform within the site. For example, a fenced pasture or a ridgetop network of timber harvests each would be considered a site. We grouped our sites into two types according to observer effort and refer to them as "core" and "peripheral”. We selected core sites based on known occurrence of breeding populations of Golden-winged Warblers (Aldinger et al. 2014). All core sites were active or abandoned cattle pastures and therefore were readily delineated by fenced boundaries. We selected peripheral sites from shrubland patches that were within the Golden-winged Warbler's contemporary breeding range and $>500$ m elevation (Roth et al. 2012, Crawford et al. 2016). Peripheral sites were 0.4$76.7 \mathrm{~km}$ from the nearest core site. The number of core (range $=7-15$ sites per year) and peripheral sites (range $=1-80$ sites per year) changed over time with a general trend of expanding our study area except in 2015 (Figure 1). Thus, the amount of area monitored on core (range = 129-670 ha) and peripheral sites (range = 45-2,063 ha) also changed over time (Figure 1).

\section{Adult Vermivora Census}

During April-June 2008-2015, we captured adult (i.e., after hatch year) Golden-winged Warblers, Blue-winged Warblers, and hybrids in mist nets using conspecific song audio lures (mean capture date $\pm \mathrm{SE}=14$ May \pm 1 day, median = 12 May, range = 29 April-27 June). We marked adults with unique combinations of up to three colored leg bands and one USGS aluminum leg band to allow for individual identification by re-sighting with binoculars. We recorded age using plumage characteristics (second year [SY], after second year [ASY], or after hatch year [AHY]; Pyle 1997), phenotype (Golden-winged Warbler, Blue-winged Warbler, Brewster’s Warbler hybrid, Lawrence’s Warbler hybrid; Parkes 1951), and sex.

Within core sites, we searched shrubland vegetation at least every three days during dawn to 1400 EDT during May and June. To ensure that we searched all shrubland cover, we used 
point count locations as a type of spot-mapping grid (Robbins 1970, Bibby et al. 2000). As part of another study, all shrubland cover within core sites was $\leq 200 \mathrm{~m}$ from a point count location (Aldinger and Wood 2015, Aldinger et al. 2017). When we encountered a male Vermivora warbler, we followed him to determine his identity and recorded up to 30 locations per day with a Garmin global positioning system (GPS) unit typically accurate to $<5 \mathrm{~m}$. We watched individual males for behavioral cues that suggested his nesting period was complete to avoid recording locations not representative of his breeding territory (e.g., fledgling feeding, frequent or extended extra-territorial movements, and lack of singing and territorial defense). We delineated a territory when we observed a male on $\geq 3$ visits or confirmed nesting in a specific location across $\geq 8$ visits to a pasture (Robbins 1970, Bibby et al. 2000). Including territory mapping, nest searching, and point counts, we made $\geq 8$ visits to all core sites each year (mean \pm $\mathrm{SE}=20 \pm 1$ visits per site per year, median = 19 visits, range $=8-39$ visits). We used 50\% of the GPS locations for each male to delineate minimum convex polygon (MCP) territories using function $m c p$ in package adehabitatHR (version 0.4.15, Calenge 2006) in program $\mathrm{R}$ (version 3.4.4, R Development Core Team 2018). We considered 50\% MCPs to represent the core use area of a male’s breeding territory (Frantz et al. 2016). We assigned geographic coordinates of the centroid of the 50\% MCP as an estimate of the male's activity center. We also assigned these coordinates to banded females found to be paired with that male. We used 50\% MCP centroids as activity centers because we did not have nest locations associated with all adults (Schaub and Royle 2014).

At peripheral sites during 20 May-25 June 2008-2015, we conducted single-visit 13-min point counts with 10 mins of passive listening, followed by 1.5 mins of type 2 conspecific song audio lure, and ending with another 1.5 mins of silent listening (Aldinger and Wood 2015, Aldinger et al. 2017). Our objective was to detect banded Vermivora warblers that may have dispersed from our core sites, although we also opportunistically banded adult birds on peripheral sites. Peripheral sites were 0.4-76.7 km from the nearest core site. Peripheral sites had 1-10 point count locations (median $=2$ point count locations per peripheral site) depending on the amount of shrubland cover present, for a total of 238 unique point count locations across our study (range $=11-188$ unique point count locations per peripheral site per year). After completing a point count, we also opportunistically searched for Vermivora warblers within 200 m of the point count location when we encountered vegetation structure characteristic of 
Golden-winged Warbler nest sites (Aldinger and Wood 2014). However, we did not record the amount of effort dedicated to these opportunistic searches. If we encountered a Vermivora warbler before the point count, we confirmed its identity and recorded the location of a song perch for males or simply the bird's location for females with a Garmin GPS unit prior to conducting the point count. For Vermivora warblers encountered during or after the point count, we allowed the bird to return to undisturbed behavior prior to recording a location. We assumed that these locations were representative of the warbler's breeding territory because our point counts occurred during the peak of the nesting period (Aldinger and Wood 2014). We delineated a 190-m buffer around each point count location within a peripheral site to represent the amount of area monitored, which was based on the 190-m maximum observed detection distance for Golden-winged Warblers using 3-min point counts with conspecific audio lure on these sites (Aldinger and Wood 2015).

\section{Nestling Banding}

We located Vermivora nests $(\mathrm{n}=196)$ during May-June 2008-2014 using standard nest-searching methods (Martin and Geupel 1993). To reduce bias associated with discovering a disproportionate number of nests in more open vegetation, we followed behavioral cues of adults such as nest material or food carries, female tzip calls, male muted song, and inconspicuous movements to areas with nesting cover to discover nests (Ficken and Ficken 1968, Highsmith 1989). To monitor nests, we traveled along existing livestock trails and openings to reduce disturbance to nests and vegetation and to reduce risk of observer-mediated nest depredation (e.g., creating trails to the nest, Martin and Geupel 1993). We banded nestlings (i.e., hatch year [HY] warblers) at 4-5 days old because nestlings were young enough to avoid forced premature fledging and old enough to retain bands on their legs and because females are not known to abandon nests at this stage (Neville et al. 2008, Bulluck et al. 2013, Streby et al. 2013). We classified nestlings as Golden-winged Warblers ( $₫$ Golden-winged Warbler $\times q$ Golden-winged Warbler), Blue-winged Warbler ( $₫$ Blue-winged Warbler $\times q$ Blue-winged Warbler), or hybrid (any combination of more than one parental phenotype). We banded all nestlings with one colored leg band and one USGS aluminum leg band. We banded all nestlings within a year with the same cohort-specific color combination and changed the color combination each year to distinguish the year in which a nestling was banded if relocated. Nestlings that returned in subsequent years as adults were recaptured and additional 
colored leg bands added for individual identification. For analyses, we only included nestlings that successfully fledged and we assigned the GPS coordinates of the nest as their activity center. We also placed a mist net near the nest while banding nestlings to capture adult Vermivora warbler parents that were not yet banded. Adults were banded with unique combinations of up to three colored leg bands and one USGS aluminum leg band.

\section{Land Cover}

We used manually-digitized land cover data from Aldinger et al. (2017) to map Goldenwinged Warbler habitat availability within 5-km of all sites. Cover types included barren (no vegetation), forest (nearly 100\% closed canopy consisting of trees $>10 \mathrm{~cm}$ diameter at breast height [dbh]), herbaceous (dominated by grasses and forbs with $<30 \%$ woody cover), shrubland ( $\geq 30 \%$ cover of shrub species such as autumn olive [Elaeagnus umbellate], hawthorn [Crataegus spp.], multiflora rose [Rosa multiflora], and shrubby St. Johnswort [Hypericum prolificum] with scattered trees and an herbaceous understory), young forest (regenerating forest stands generally resulting from timber harvest, dominated by saplings $\leq 10 \mathrm{~cm}$ dbh, displaying distinct edges against surrounding forest, and often dissected by logging roads), open water, road, and structures (Aldinger et al. 2017). We defined shrubland and young forest cover types as available habitat within which Vermivora warblers could be encountered (Confer et al. 2011, Aldinger et al. 2017).

\section{Data Analysis}

We used encounter histories and spatial locations of banded nestling and adult Vermivora warblers to estimate annual survival and dispersal during 2008-2015 using a modified version of the s-CJS model in Schaub and Royle (2014). The model of Schaub and Royle (2014) is a generalized version of the traditional CJS model with an additional sub-model for the dispersal process to separate death and emigration when estimating annual survival. In other words, the sCJS model allows for estimation of true survival rather than apparent survival by using observed dispersal movements to account for dispersal that results in permanent emigration from a site. Captures and recaptures are only possible within the boundary of a defined site, either core or peripheral sites in our study. Encounter histories were stored in a matrix $\boldsymbol{Y}$ with elements $Y_{i, t}$, where $Y_{i, t}$ equals 1 if warbler $i$ was encountered during year $t$ and 0 if warbler $i$ was not encountered during year $t$. Spatial locations (i.e., 50\% MCP centroids, resighting locations, and nests) were stored in array $\boldsymbol{G}$ with elements $G_{i, t, 1}$, the x-coordinate for warbler $i$ encountered 
during year $t$, and $G_{i, t, 2}$, the y-coordinate for warbler $i$ encountered during year $t$. When warbler $i$ was not encountered during year $t, G_{i, t, 1}$ and $G_{i, t, 2}$ were missing values. For banded adult male and female Vermivora warblers with mapped breeding territories on our core sites, we used the 50\% MCP centroid coordinates in $\boldsymbol{G}$. For adult male and female Vermivora warblers encountered on our peripheral sites, we used the resighting coordinates in $\boldsymbol{G}$. For nestlings, we used the nest coordinates in $\boldsymbol{G}$.

The s-CJS model includes two state processes and one observation process (Schaub and Royle 2014). The first state process describes the state (live or dead) of warbler $i$ in each year $t$ as the outcome of a Bernoulli process, defined by survival probability s. This process conditions on the previous state of warbler $i$, such that only warblers alive during year $t-1$ may be alive during year $t$. The second state process describes the dispersal location variable $\boldsymbol{G}$, which we modified so that warbler dispersal locations were constrained to only occur in shrubland and young forest from our manually digitized land cover data. This differs from the model of Schaub and Royle (2014), who allowed dispersal to occur into any location. Dispersal was treated as a Markovian random-walk process with potential dispersal locations following an inverse gamma distribution. Because dispersal locations were restricted to land cover that we digitized within a 5-km buffer around our sites, we technically were estimating apparent survival because warblers may disperse farther than 5-km. Nonetheless, our observed dispersal events $(n=167)$ all were less than 5-km (Figure 2) and for most core sites we had land cover data extending beyond a 5-km radius because of surrounding peripheral sites (Figure 3). Therefore, we expect that our estimates of apparent survival still closely approximate true survival. The observation process (i.e., detection probability) is the final step in the s-CJS model. Only warblers that are alive and present within the state space $\boldsymbol{A}$ representing our study area are available for capture. We accounted for annual variation in the size of our study area (Figure 1) by annually varying the size of the state space $\boldsymbol{A}$ in our model (Schaub and Royle 2014). For testing whether each location $\mathrm{G}_{i, t}$ was located within a site, we converted our polygon shapefiles for site boundaries and land cover to raster files with $315 \mathrm{~m}$ x $315 \mathrm{~m}$ grid cells (9.9 ha). A raster file of this resolution would cause smaller sites to disappear and small patches of shrubland and young forest land cover to be merged with surrounding land cover classes (usually forest). Therefore, we first converted the polygon shapefiles to $1 \mathrm{~m} \times 1 \mathrm{~m}$ raster files, then used the aggregate tool in ArcMap for Desktop (version 10.4.1, ESRI 2015) to aggregate the $1 \mathrm{~m} \mathrm{x} 1 \mathrm{~m}$ raster files into 
315 m x 315 m raster files. The aggregate tool assigned a value to each 315 m x 315 m cell corresponding to the composition of the $1 \mathrm{~m} \mathrm{x} 1 \mathrm{~m}$ cells that were aggregated. We used this value to create more liberal boundaries for sites and patches of shrubland and young forest cover. This delineation method overestimates the extent of our sites and shrubland and young forest cover, but it was necessary to ensure that all Vermivora warbler locations occurred within site and shrubland and young forest cover boundaries.

We ran the s-CJS model in a Bayesian framework using program JAGS (Plummer 2003) executed in package jagsUI (Kellner 2017) in program R (version 3.4.4, R Development Core Team 2018). We estimated annual survival by age, phenotype, sex, and study area, dispersal by age, and detection probability by site type because of variation in effort (Reidy et al. 2018). We assumed a logistic $(0,1)$ prior distribution on all survival and detection probability slope coefficients (Rota et al. 2016). Our covariate for age had two categories, with juvenile annual survival defined as the interval between HY and SY and adult annual survival as the interval between AHY and AHY, which is any interval between two AHY years. We predicted that adult annual survival would be significantly higher than juvenile annual survival, as has been consistently found among migratory passerines (Gardali et al. 2003). Our primary considerations in this comparison were simply to quantify juvenile annual survival and evaluate its magnitude relative to adult annual survival because these parameters had not been estimated for Goldenwinged Warblers despite a documented need to do so (Bulluck et al. 2013, Rohrbaugh et al. 2016). Our phenotype covariate had levels for Golden-winged Warbler, Blue-winged Warbler, and hybrid, and we predicted that survival would vary by phenotype because of variation in their respective non-breeding ranges (Kramer et al. 2018). To estimate survival by sex, we used only AHY warblers because we did not know the sex of banded nestlings unless they returned as adults. Our study area covariate had two levels representing northern and southern study areas (Figure 3). Our northern study area had a rapidly decreasing population of Golden-winged Warblers centered around core sites in northern Randolph County, while our southern study area had a relatively stable population of Golden-winged Warblers centered around core sites in southern Pocahontas County (Chapter 6). We compared annual survival among these study areas because variation in non-breeding season survival may be associated with local population trends (Donovan and Thompson 2001). We used AHY Golden-winged Warbler males from the southern study area as the baseline or reference level in our s-CSJ model when estimating 
survival probability. For all results of our s-CJS model, we reported posterior means and 95\% confidence intervals (CI) in the results section.

We also estimated dispersal by age in our s-CJS model, with natal dispersal defined as movement during the HY-AHY interval and breeding dispersal defined as movement during the AHY-AHY interval. We assumed inverse gamma $(1,1)$ prior distributions on dispersal variance parameters. We modeled dispersal by age because of the general tendency among migratory songbirds for low natal philopatry and high adult breeding site fidelity (Greenwood 1980, Sedgwick 2004). We also wanted to model dispersal by sex because of female-biased dispersal documented for some migratory songbirds (Greenwood 1980) but did not have sufficient sample size to model both age and sex. To provide a baseline for future research and to help inform conservation efforts, we reported additional descriptive statistics for observed dispersal by age, sex, study area, and phenotype.

\section{RESULTS}

We banded 517 Vermivora warblers during 2008-2014 (Table 1). During 2009-2015, we resighted $21 \%$ of warblers $(n=109$, Figure 4$)$ in multiple years for a total of 684 warbler locations. Maximum observed longevity was 5 years old $(n=2)$ among adults where exact age in years was known ( $\mathrm{n}=102$, Figure 4). However, 2 Golden-winged Warbler males aged as ASY at the time of banding achieved an age of $\geq 6$ years old. Twenty-one warblers banded as nestlings were resighted as adults for a natal return rate of 7\% (21 / 301). We captured and confirmed band numbers for 18 of these natal returns. Three sets of 2 siblings were resighted and one set of malefemale siblings ultimately attempted two unsuccessful nests together.

Based on our s-CJS model, Vermivora warbler annual survival did not vary by phenotype, sex, or study area, but juvenile annual survival (HY-SY, posterior mean $=0.09,95 \%$ $\mathrm{CI}=0.05-0.13$ ) was significantly lower than adult annual survival (AHY-AHY, posterior mean $=0.53,95 \% \mathrm{CI}=0.46-0.60$; Table 2 ). Detection probability was not significantly different between the two site types, but it was less than 1.0 on both core (posterior mean $=0.82,95 \% \mathrm{CI}$ $=0.72-0.90$ ) and peripheral sites (posterior mean $=0.79,95 \% \mathrm{CI}=0.52-0.97$ ).

Based on our s-CJS model, mean expected breeding dispersal distance was 329 m (95\% $\mathrm{CI}=316-344 \mathrm{~m})$ and mean expected natal dispersal distance was $544 \mathrm{~m}(95 \% \mathrm{CI}=500-592 \mathrm{~m}$, Figure 5). On average, observed dispersal distance decreased with age and females dispersed 
farther than males (Table 2, Figure 2). A female Golden-winged Warbler natal dispersal event was our farthest observed dispersal (4,404 m).

\section{DISCUSSION}

Among the numerous studies of Golden-winged Warbler demographic parameters throughout the species' range, minimally-biased estimates of annual survival and dispersal are still lacking (Confer et al. 2011, Streby et al. 2016a). This is a notable knowledge gap with conservation implications because adult and juvenile annual survival can be primary drivers of population growth (Donovan and Thompson 2001). Furthermore, effective conservation planning and network design require empirical data on dispersal, especially for species like the Golden-winged Warbler that occur in small, isolated, and ephemeral populations (Macdonald and Johnson 2001). For Golden-winged Warblers, we provide the first estimates of adult (mean = $0.53,95 \% \mathrm{CI}=0.46-0.60$ ) and juvenile (mean $=0.09,95 \% \mathrm{CI}=0.05-0.13$ ) annual survival with a s-CJS model that accounted for permanent emigration, expected breeding (mean $=329 \mathrm{~m}, 95 \%$ $\mathrm{CI}=316-344 \mathrm{~m}$ ) and natal dispersal $($ mean $=544 \mathrm{~m}, 95 \% \mathrm{CI}=500-592 \mathrm{~m}$ ), and variation in observed dispersal distance by age and sex (Figures 2, 5). Our s-CJS model estimates of annual survival and dispersal are unique in that they account for the species' breeding ecology by constraining expected dispersal events to occur within mapped discrete patches of nesting habitat. Such constraint is expected to improve estimates of survival and dispersal compared to a model where dispersal is unconstrained (Schaub and Royal 2014). This study serves as a starting point for more in-depth, geographically-extensive, and collaborative investigations of Goldenwinged Warbler annual survival and dispersal.

We are aware of annual survival estimates from two other locations across the Goldenwinged Warbler's breeding range. Apparent adult annual survival was similar for populations in Ontario and Tennessee but varied by sex (Ontario male $=0.618 \pm 0.08 \mathrm{SE}$, Ontario female $=$ $0.477 \pm 0.14 \mathrm{SE}$, Tennessee male $=0.616 \pm 0.11 \mathrm{SE}$, Tennessee female $=0.427 \pm 0.12 \mathrm{SE}$; Bulluck et al. 2013). Interestingly, our true adult annual survival estimate (0.53) was almost identical to average apparent adult annual survival estimates for both Ontario $([0.618+0.477] / 2$ $=0.522)$ and Tennessee $([0.616+0.427] / 2=0.548)$ from Bulluck et al. (2013). Because

apparent annual survival generally underestimates true annual survival (Schaub and Royle 2014), this similarity prompts multiple questions about these specific estimates with broader 
implications for Golden-winged Warbler annual survival estimation. First, could adult breeding site fidelity be high enough that apparent survival closely approximates true annual survival? Both studies of Golden-winged Warblers that used mark-recapture methods specifically discuss strong site fidelity in support of their apparent annual survival estimates (Chandler and King 2011, Bulluck et al. 2013). It is also possible that Golden-winged Warblers and their habitat may be rare enough and study designs intensive enough that researchers can detect sufficient dispersal events so that apparent annual survival estimates are minimally biased (Aldinger et al. 2017, Bulluck et al. 2018). If the answer to this first question is "no", however, then a second question arises: could true annual survival be lower in West Virginia than both Ontario and Tennessee? We expect that the answer to this question is "no" and that a more plausible expectation would be that true annual survival is higher in Ontario than in Tennessee and West Virginia. North American Breeding Bird Survey results indicate that Golden-winged Warbler populations in Tennessee and West Virginia are both decreasing by 8-9\% per year but populations in Ontario are relatively stable (0.9\% increase per year, Sauer et al. 2017). Kramer et al. (2018) similarly suggested that Golden-winged Warblers in the Appalachian Mountains population segment (i.e., Tennessee and West Virginia) would have lower non-breeding season survival than warblers in the Great Lakes population segment (i.e., Ontario). This discussion is based on annual survival estimates from individual studies at three geographic locations. Not until we have additional estimates of true survival across space and time will we be able to answer these and other questions with confidence.

For the first time for Golden-winged Warblers, we also were able to estimate juvenile annual survival with our s-CJS model. The primary reason for this knowledge gap is that natal returns are so rarely encountered among migratory songbirds, with only $4.8 \pm 1.4 \%$ of banded nestlings resighted as adults across shrubland-nesting birds (Schlossberg 2009). Our natal return rate (7\%) was high for a shrubland-nesting bird and specifically was uncommon among intensively studied populations of Golden-winged Warblers based on the literature and conversations with other Golden-winged Warbler researchers (Will 1986, Bulluck et al. 2013, Golden-winged Warbler Working Group, pers. comm.). We credit our industrious field technicians and study design which resulted in 3,150 unique ha searched one or more times for Vermivora warblers during our study. The relatively high return rate may also relate to a general lack of shrubland (3\%) and young forest (1\%) nesting cover in our study area, which may have 
constrained natal dispersal to locations near the natal nest and thus increased detection probability. As for the modeled value of juvenile annual survival, we note that it included the post-fledging period when fledglings are dependent on parents ( 25 days), which is characterized by high mortality (Streby et al. 2016, Lehman 2017). No estimates of Golden-winged Warbler post-fledging survival exist for our study area to adjust our annual survival value. However, if we divide our juvenile annual survival estimate (0.09) by Lehman’s (2017) fledgling survival estimate from Tennessee (0.289), we can derive an estimate of juvenile annual survival (0.31) that is more readily comparable to our estimate of adult annual survival (0.53). The 0.58 ratio of juvenile to adult annual survival (0.31 / 0.53$)$ actually is quite close to the commonly used assumption that juvenile annual survival is half of adult annual survival (Temple and Cary 1988, Donovan et al. 1995, Bulluck et al. 2013).

As a final point about annual survival, we note that it was statistically similar among our northern and southern study areas, despite different population trends. Golden-winged Warbler populations in our northern study area almost were extirpated between 2008 ( $n=27$ territories) and 2014 ( $n=2$ territories), while populations in the southern study area fluctuated annually but remained relatively stable overall during 2009-2014 (Chapter 6). Therefore, our finding of geographically consistent annual survival reinforces results of Chapter 6 in this dissertation, where models suggested that nest survival and not return rates were associated with population trends. We infer that Golden-winged Warblers across our study area probably are using similar migratory routes and wintering locations and thus encountering similar threats during the nonbreeding period (Kramer et al. 2018).

Our other parameter of interest, Golden-winged Warbler annual dispersal distance, has only been reported from chance observations (Bulluck et al. 2013) or samples of birds discovered within a relatively small search radius (Peterson et al. 2015). In Minnesota, capture locations of 18 adult male Golden-winged Warblers moved an average of $64 \mathrm{~m}$ between consecutive breeding seasons (Peterson et al. 2015). Our mean expected breeding dispersal distance (329 m, 95\% CI = 316-344 m) was 414\% greater than the value from Peterson et al. (2015), which is expected because they searched only within a 500 m radius of original capture locations. Despite the lack of attention dispersal has received, our results suggest that natal and breeding dispersal are common behaviors among Golden-winged Warblers even at low territory densities that occurred in our study area (Frantz et al. 2016, Aldinger et al. 2017), which has 
important conservation implications. Breeding and natal dispersal are important components of population persistence and serve as mechanisms to avoid inbreeding depression (although note our sibling pair of Golden-winged Warblers), avoid competition at high densities, seek out conspecifics at low densities, respond to environmental changes, or locate higher quality breeding habitat following breeding failure, among other reasons (Greenwood 1980, Kruuk et al. 2002, Wheelright et al. 2006). Our modeled and observed results suggest that an effective network design for Golden-winged Warblers may include three tiers: a core patch of known high-quality shrubland for reproduction that allows for annual movements of $329 \mathrm{~m}$ within the patch (i.e., our expected breeding dispersal), a second tier of peripheral patches within $492 \mathrm{~m}$ of the core patch (i.e., our observed SY-ASY dispersal), and a third tier of peripheral patches within 1,587 m of the core patch (i.e., our observed HY-AHY dispersal, Table 2).

Limitations of this study and future directions are intertwined. An improved version of our model would include dispersal and detection probability parameters that incorporated age and sex (Greenwood 1980). However, achieving a large enough sample size to implement such a model may only be possible through an even longer study or a collaborative approach that incorporates strategically-placed study areas throughout the Appalachian Mountains and Great Lakes population segments (Roth et al. 2012). In addition to a more biologically-relevant model, collaboration across the species' range would allow for direct validation of the hypothesis that survival during the non-breeding season is a primary limiting factor for Golden-winged Warbler populations (Kramer et al. 2018). We also note that results of s-CJS models can be sensitive to the distribution describing dispersal (Schaub and Royle 2014, Reidy et al. 2018). Therefore, our results may be improved by comparing among s-CJS models with different dispersal distributions (e.g., Laplace, normal, $T$ ).

As often seems to be the case with study of poorly understood life history characteristics, our results may have raised as many or more questions than we have been able to answer. Our estimates of adult annual survival derived across 8 breeding seasons are similar to some of the relatively few estimates presumed to approximate true survival from other migratory songbirds on the North American breeding grounds (male and female Black-throated Blue Warblers [Setophaga caerulescens] $=0.40-0.51$, Sillett and Holmes 2002; male Golden-cheeked Warblers $=0.45-0.67$, Reidy et al. 2018). Interestingly, populations of both of these species are increasing, which raises questions about the relative contributions of different demographic rates to observed 
population trends of Golden-winged Warblers (Duarte et al. 2015, Sauer et al. 2017). Therefore, it is important that future research not only focus on annual survival and dispersal, but on overall population limiting factors throughout the Golden-winged Warbler's full-life cycle (Rohrbaugh et al. 2016, Kramer et al. 2018, Chapter 6 in this dissertation). Our minimally-biased estimates of survival and dispersal, which we hope will be supplemented by additional studies, may be used to inform Golden-winged Warbler full life-cycle models and guide conservation efforts, which to this point had lacked information on these basic life history characteristics.

\section{ACKNOWLEDGMENTS}

The Littlefield family, West Virginia Cooperative Fish and Wildlife Research Unit, and West Virginia Division of Natural Resources Elkins Operation Center provided housing. The U.S. Forest Service Monongahela National Forest allowed access to study sites. We thank J. Aldinger, I. Batterman, P. Bryant, A. Dalton, M. Frantz, C. Fitzmorris, N. Glover, J. Kreiser, C. Lauzau, K. Loucks, S. Malinich, A. Newman, V. Olmstead, K. Pratt, M. Roach, C. Roy, J. Saborse, C. Sedgwick, L. Smith, L. Stout, D. Ware, and M. Weston for long hours of work in the field. J. Anderson, G. Merovich, M. Strager, R. Tallman, and members of the Golden-winged Warbler Working Group provided valuable insight during this research. L. A. Nolan assisted with delineation of Golden-winged Warbler minimum convex polygons. The West Virginia Division of Natural Resources Wildlife Diversity Program (013555.2.1000502W), U.S. Fish and Wildlife Service Migratory Bird Program (F12AP00643), U.S. Forest Service Monongahela National Forest (12-PA-11092100-020), U.S. Natural Resources Conservation Service (68-748212-502), and the National Fish and Wildlife Foundation (10012877.1.1004706R) granted funding for this research. Co-author C.M.J. is affiliated with the U.S. Forest Service Monongahela National Forest, one of the funding sources. None of the funders required approval of the manuscript before submission or publication. Any use of trade, firm, or product names is for descriptive purposes only and does not imply endorsement by the U.S. Government. This study was completed under the auspices of West Virginia University Institutional Animal Care and Use Committee protocols 07-0303 and 10-0201.

\section{LITERATURE CITED}


Akresh, M. E., D. I. King, and R. T. Brooks. 2015. Demographic response of a shrubland bird to habitat creation, succession, and disturbance in a dynamic landscape. Forest Ecology and Management 336:72-80.

Aldinger, K. R., and P. B. Wood. 2014. Reproductive success and habitat characteristics of Golden-winged Warblers in high-elevation pasturelands. Wilson Journal of Ornithology 126:279-287.

Aldinger, K. R., and P. B. Wood. 2015. Variables associated with detection probability, detection latency, and behavioral responses of Golden-winged Warblers (Vermivora chrysoptera). Condor 117:364-375.

Aldinger, K. R., P. B. Wood, and C. M. Johnson. 2017. Refined conservation strategies for Golden-winged Warblers in the West Virginia highlands with implications for the broader avian community. Condor 119:762-786.

Anich, N. M., T. J. Benson, J. A. Gerwin, N. A. Chartier, B. M. Reiley, J. L. Everitts, J. C. Bednarz, and S. F. Tolfree. 2017. Natal philopatry and juvenile survival in Swainson's Warblers (Limnothlypis swainsonii). Wilson Journal of Ornithology 129:850-859.

Bakermans, M., B. W. Smith, B. C. Jones, and J. L. Larkin. 2015. Stand and within-stand factors influencing Golden-winged Warbler use of regenerating stands in the central Appalachian Mountains. Avian Conservation and Ecology 10:10.

Bibby, C. J., N. D. Burgess, D. A. Hill, and S. H. Mustoe. 2000. Bird Census Techniques, second edition. Academic Press, London, UK.

Bulluck, L., D. Buehler, R. Vallender, and R. J. Robertson. 2013. Demographic comparison of Golden-winged Warbler (Vermivora chrysoptera) populations in northern and southern extremes of their breeding range. Wilson Journal of Ornithology 125:479-490.

Calenge, C. 2006. The package adehabitat for the R software: a tool for the analysis of space and habitat use by animals. Ecological Modelling 197: 516-519.

Chandler, R. B., and D. I. King. 2011. Habitat quality and habitat selection of Golden-winged Warblers in Costa Rica: an application of hierarchical models for open populations. Journal of Applied Ecology 48:1038-1047.

Cilimburg, A. B., M. S. Lindberg, J. J. Tewksbury, and S. J. Hejl. 2002. Effects of dispersal on survival probability of adult Yellow Warblers (Dendroica petechia). Auk 119:778-789.

Cline, M. H., A. M. Strong, T. S. Sillett, N. L. Rodenhouse, and R. T. Holmes. 2013. Correlates and consequences of breeding dispersal in a migratory songbird. Auk 130:742-752.

Confer, J. L., P. Hartman, and A. Roth. 2011. Golden-winged Warbler (Vermivora chrysoptera), version 2.0. In The Birds of North America Online (P. Rodewald, Editor). Cornell Laboratory of Ornithology, Ithaca, NY, USA. https://birdsna.org/SpeciesAccount/bna/species/gowwar.

Crawford, D. L., R. W. Rohrbaugh, A. M. Roth, J. D. Lowe, S. B. Swarthout, and K. V. Rosenberg. 2016. Landscape-scale habitat and climate correlates of breeding Goldenwinged and Blue-winged warblers. In Golden-winged Warbler Ecology, Conservation, and Habitat Management (H. M. Streby, D. E. Andersen, and D. A. Buehler, Editors). Studies in Avian Biology 49:41-66. 
DeGraf, R. M., and M. Yamasaki. 2003. Options for managing early-successional forest and shrubland bird habitats in the northeastern United States. Forest Ecology and Management 185:179-191.

Dettmers, R. 2003. Status and conservation of shrubland birds in the northeastern US. Forest Ecology and Management 185:81-93.

Donovan, T. M., and F. R. Thompson III. 2001. Modeling the ecological trap hypothesis: a habitat and demographic analysis for migrant songbirds. Ecological Applications 11:871882.

Donovan, T. M., F. R. Thompson III, and J. Faaborg. 1995. Reproductive success of migratory birds in habitat sources and sinks. Conservation Biology 9:1380-1395.

Duarte, A., F. W. Weckerly, M. Schaub, and J. S. Hatfield. 2015. Estimating Golden-cheeked Warbler immigration: implications for the spatial scale of conservation. Animal Conservation 19:65-74.

ESRI. 2015. ArcGIS Desktop: Release 10. Environmental Systems Research Institute, Redlands, CA, USA.

Faaborg, J., R. T. Holmes, A. D. Anders, K. L. Bildstein, K. M. Dugger, S. A. Gauthreaux, Jr., P. Heglund, K. A. Hobson, A. E. Jahn, D. H. Johnson, S. C. Latta, D. J. Levey, P. P. Marra, C. L. Merkord, E. Nol, S. I. Rothstein, T. W. Sherry, T. S. Sillett, F. R. Thompson III, and N. Warnock. 2010. Conserving migratory land birds in the New World: do we know enough? Ecological Applications 20:398-418.

Ficken, M. S., and R. W. Ficken. 1968. Courtship of Blue-winged Warblers, Golden-winged Warblers, and their hybrids. Wilson Bulletin 80:161-172

Frantz, M. W., K. R. Aldinger, P. B. Wood, J. Duchamp, T. Nuttle, A. Vitz, and J. L. Larkin. 2016. Space and habitat use of breeding Golden-winged Warblers in the central Appalachian Mountains. In Golden-winged Warbler Ecology, Conservation, and Habitat Management (H. M. Streby, D. E. Andersen, and D. A. Buehler, Editors). Studies in Avian Biology 49:81-94.

Gardali, T., D. C. Barton, J. D. White, and G. R. Geupel. 2003. Juvenile and adult survival of Swainson's Thrush (Catharus ustulatus) in coastal California: annual estimates using capture-recapture analyses. Auk 120:118-1194.

Gifford, N. A., J. M. Deppen, J. T. Bried. 2010. Importance of an urban pine barrens for the conservation of early-successional shrubland birds. Landscape and Urban Planning 94:54-62.

Gill, F. B. 2004. Blue-winged Warblers (Vermivora pinus) versus Golden-winged Warblers (Vermivora chrysoptera). Auk 121:1014-1018.

Greenwood, P. J. 1980. Mating systems, philopatry, and dispersal in birds and mammals. Animal Behaviour 28:1140-1162.

Highsmith, R. T. 1989. The singing behavior of Golden-winged Warblers. Wilson Bulletin 101:36-50. 
Kellner, K. F. 2017. jagsUI: A wrapper around rjags to streamline JAGS analyses. R package version 1.4.9. https://cran.r-project.org/web/packages/jagsUI/index.html.

King, D. I., and S. Schlossberg. 2014. Synthesis of the conservation value of the earlysuccessional stage in forests of eastern North America. Forest Ecology and Management 324:186-195.

Kramer, G. R., D. E. Andersen, D. A. Buehler, P. B. Wood, S. M. Peterson, J. A. Lehman, K. R. Aldinger, L. P. Bulluck, S. Harding, J. A. Jones, J. P. Loegering, C. Smalling, R. Vallender, and H. M. Streby. 2018. Population trends in Vermivora warblers are linked to strong migratory connectivity. Proceedings of the National Academy of Sciences of the United States of America DOI: 10.1073/pnas.1718985115.

Kruuk, L. E. B., B. C. Sheldon, J. and Merila. 2002. Severe inbreeding depression in Collared Flycatchers (Ficedula albicollis). Proceedings of the Royal Society B 269:1581-1589.

Kubel, J. E., and R. H. Yahner. 2007. Detection probability of Golden-winged Warblers during point counts with and without playback recordings. Journal of Field Ornithology 78:195205.

Lebreton, J. D., K. P. Burnham, J. Clobert, and D. R. Anderson. 1992. Modeling survival and testing biological hypothesis using marked animals: a unified approach with case studies. Ecological Monographs 62:67-118.

Lehman, J. A. 2017. Survival and habitat selection of Golden-winged Warblers (Vermivora chrysoptera) during nesting and post-fledging periods at North Cumberland Wildlife Management Area, Tennessee. Master's thesis, University of Tennessee, Knoxville, TN, USA.

Macdonald, D. W., and D. D. P. Johnson. 2001. Dispersal in theory and practice: consequences for conservation biology. Pgs. 358-372 in Dispersal (J. Clobert, E. Danchin, A. A. Dhondt, and J. D. Nichols, Editors). Oxford University Press, Oxford.

Martin, T. E., and G. R. Geupel. 1993. Nest-monitoring plots: methods for locating nests and monitoring success. Journal of Field Ornithology 64:507-519.

Neville, K. J., R. Vallender, and R. J. Robertson. 2008. Nestling sex ratio of Golden-winged Warblers Vermivora chrysoptera in an introgressed population. Journal of Avian Biology 39:599-604.

Omernik, J. M., and G. E. Griffith. 2014. Ecoregions of the conterminous United States: evolution of a hierarchical spatial framework. Environmental Management 54:1249_ 1266.

Parkes, K. C. 1951. The genetics of the Golden-winged $\times$ Blue-winged warbler complex. Wilson Bulletin 63:5-15.

Patton, L. L., D. S. Maehr, J. E. Duchamp, S. Fei, J. W. Gassett, and J. L. Larkin. 2010. Do the Golden-winged Warbler and Blue-winged Warbler exhibit species-specific differences in their breeding habitat use? Avian Conservation and Ecology 5:2.

Peterson, S. M., H. M. Streby, G. R. Kramer, J. A. Lehman, D. A. Buehler, and D. E. Andersen. 2015. Geolocators on Golden-winged Warblers do not affect migratory ecology. Condor 117:256-261. 
Plummer, M. 2003. JAGS: A program for analysis of Bayesian graphical models using Gibbs sampling. Proceedings of the 3rd International Workshop on Distributed Statistical Computing, Vienna, Austria.

Pyle, P. 1997. Identification guide to North American birds, part 1: Columbidae to Ploceidae. Slate Creek Press, Bolinas, CA, USA.

R Development Core Team. 2018. R: A language and environment for statistical computing. Version 3.4.4. R Foundation for Statistical Computing. Vienna, Austria. www.rproject.org.

Reidy, J. L., F. R. Thompson III, G. M. Connette, and L. O’Donnell. 2018. Demographic rates of Golden-cheeked Warblers in an urbanizing woodland preserve. Condor 120:249-264.

Robbins, C. S. 1970. An international standard for a mapping method in bird census work. International Bird Census Committee. Audubon Field Notes 24:722-726.

Rohrbaugh, R. W., D. A. Buehler, S. B. Swarthout, D. I. King, J. L. Larkin, K. V. Rosenberg, A. M. Roth, R. Vallender, and T. Will. 2016. Conservation perspectives: Review of new science and primary threats to Golden-winged Warblers. In Golden-winged Warbler Ecology, Conservation, and Habitat Management (H. M. Streby, D. E. Andersen, and D. A. Buehler, Editors). Studies in Avian Biology 49:207-215.

Rota, C. T., M. A. R. Ferreira, R. W. Kays, T. D. Forrester, E. L. Kalies, W. J. McShea, A. W. Parsons, and J. J. Millspaugh. 2016. A multispecies occupancy model for two or more interacting species. Methods in Ecology and Evolution 7:1164-1173.

Roth, A. M., R. W. Rohrbaugh, K. R. Aldinger, M. H. Bakermans, S. Barker Swarthout, D. A. Buehler, J. L. Confer, D. Crawford, C. Friis, R. M. Fowlds, J. L. Larkin, J. Loegering, J. D. Lowe, M. Piorkowski, K. V. Rosenberg, C. Smalling, T. M. Terhune, R. Vallender, T. Will, and P. B. Wood. 2012. Golden-winged Warbler breeding season conservation plan. In Golden-winged Warbler Status Review and Conservation Plan (A. M. Roth, R. W. Rohrbaugh, T. Will, and D. A. Buehler, Editors). www.gwwa.org/plan.

Rushing, C. S., T. B. Ryder, and P. P. Marra. 2016. Quantifying drivers of population dynamics for a migratory bird throughout the annual cycle. Proceedings of the Royal Society B 283:2040-2042.

Sauer, J. R., D. K. Niven, J. E. Hines, D. J. Ziolkowski, Jr, K. L. Pardieck, J. E. Fallon, and W. A. Link. 2017. The North American Breeding Bird Survey, Results and Analysis 1966 2015. Version 2.07.2017 USGS Patuxent Wildlife Research Center, Laurel, MD, USA.

Schaub, M., and J. A. Royle. 2014. Estimating true instead of apparent survival using spatial Cormack-Jolly-Seber models. Methods in Ecology and Evolution 5:1316-1326.

Schlossberg, S. 2009. Site fidelity of shrubland and forest birds. Condor 111:238-246.

Sedgwick, J. A. 2004. Site fidelity, territory fidelity, and natal philopatry in Willow Flycatchers (Empidonax traillii). Auk 121:1103-1121.

Sherry, T. W., and R. T. Holmes. 1995. Summer versus winter limitation of populations: what are the issues and what is the evidence? Pages 85-120 in T. E. Martin and D. M. Finch, editors. Ecology and management of Neotropical migratory birds. Oxford University Press, New York, NY, USA. 
Sillett, T. S., and R. T. Holmes. 2002. Variation in survivorship of a migratory songbird throughout its annual cycle. Journal of Animal Ecology 71:296-308.

Streby, H. M., D. E. Andersen, and D. A. Buehler (Editors). 2016a. Golden-winged Warbler Ecology, Conservation, and Habitat Management. Studies in Avian Biology 49.

Streby, H. M., T. L. McAllister, S. M. Peterson, G. R. Kramer, J. A. Lehman, and D. E. Andersen. 2015. Minimizing marker mass and handling time when attaching radiotransmitters and geolocators to small songbirds. Condor 117:249-255.

Streby, H. M., S. M. Peterson, and D. E. Andersen. 2016b. Survival and habitat se of fledgling Golden-winged Warblers in the western Great Lakes region. In Golden-winged Warbler Ecology, Conservation, and Habitat Management (H. M. Streby, D. E. Andersen, and D. A. Buehler, Editors). Studies in Avian Biology 49:127-140.

Streby, H. M., S. M. Peterson, J. A. Lehman, G. R. Kramer, K. J. Iknayan, and D. E. Andersen. 2013. The effects of force-fledging and premature fledging on the survival of nestling songbirds. Ibis 155:616-620.

Temple, S. A., and J. R. Cary. 1988. Modeling dynamics of habitat-interior bird populations in fragmented landscapes. Conservation Biology 2:340-347.

Toews, D. P. L., S. A. Taylor, R. Vallender, A. Brelsford, B. G. Butcher, P. W. Messer, and I. J. Lovette. 2016. Plumage genes and little else distinguish the genomes of hybridizing warblers. Current Biology 26:2313-2318.

Weatherhead, P. J., and M. R. L. Forbes. 1994. Natal philopatry in passerine birds: genetic or ecological influences? Behavioral Ecology 5:426-433.

Welton, M. 2003. Status and distribution of the Golden-winged Warbler in Tennessee. Migrant 74:61-82.

West Virginia GIS Technical Center. 2012. Landuse/Landcover of West Virginia 2011. West Virginia GIS Technical Center, West Virginia University, Morgantown, WV, USA. wvgis.wvu.edu/data/dataset.php?ID=451.

Wheelright, N. T., C. R. Freeman-Gallant, and R. A. Mauck. 2006. Asymmetrical incest avoidance in the choice of social and genetic mates. Animal Behaviour 71:631-639.

Will, T. C. 1986. The behavioral ecology of species replacement: Blue-winged and Goldenwinged warblers in Michigan. Ph.D. dissertation, University of Michigan, Ann Arbor, MI, USA. 


\section{TABLES}

Table 1. Sample sizes of Golden-winged Warbler (Vermivora chrysoptera), Blue-winged Warbler ( $V$. cyanoptera), and hybrids (V. chyrsoptera x cyanoptera) banded in the Allegheny Mountains of West Virginia during 2008-2014 and available for resighting during 2009-2015.

\begin{tabular}{|c|c|c|c|c|}
\hline $\operatorname{Sex}^{\dagger}$ & Golden-winged Warbler & Blue-winged Warbler & Hybrid & Total \\
\hline Male & 135 & 11 & 12 & 158 \\
\hline SY & 58 & 5 & 5 & 68 \\
\hline ASY & 74 & 6 & 7 & 87 \\
\hline AHY & 3 & 0 & 0 & 3 \\
\hline Female & 53 & 1 & 4 & 58 \\
\hline SY & 15 & 1 & 1 & 17 \\
\hline ASY & 35 & 0 & 3 & 38 \\
\hline AHY & 3 & 0 & 0 & 3 \\
\hline Nestling (HY) & 246 & 5 & 50 & 301 \\
\hline Total & 434 & 17 & 66 & 517 \\
\hline
\end{tabular}

${ }^{\dagger} \mathrm{HY}=$ hatch year, SY = second year, ASY = after second year, AHY = after hatch year 
Table 2. Summary statistics for survival probability and observed dispersal distance of Goldenwinged Warblers, Blue-winged Warblers, and hybrids banded and resighted in the Allegheny Mountains of West Virginia during 2008-2015. Survival probabilities were estimated with a spatial Cormack-Jolly-Seber model using after hatch year Golden-winged Warbler males from the southern study area as the baseline or reference level (s-CJS, Schaub and Royle 2014). Based on our s-CJS model, expected breeding dispersal distance was $329 \mathrm{~m}(95 \% \mathrm{CI}=316-344 \mathrm{~m})$ and expected natal dispersal distance was $544 \mathrm{~m}(95 \% \mathrm{CI}=500-592 \mathrm{~m})$. Ages include hatch year (HY), second year (SY), after second year (ASY), and after hatch year (AHY).

\begin{tabular}{|c|c|c|c|}
\hline \multirow[b]{2}{*}{ Covariate } & \multirow{2}{*}{$\begin{array}{l}\text { Mean survival } \\
(95 \% \mathrm{CI})^{\mathrm{a}}\end{array}$} & \multicolumn{2}{|c|}{ Observed dispersal distance (m) } \\
\hline & & Mean $( \pm 1 \mathrm{SE})^{\mathrm{b}}$ & Median (IQR) ${ }^{\mathrm{c}}$ \\
\hline \multicolumn{4}{|l|}{ Age } \\
\hline HY-AHY & $0.08(0.05-0.13)$ & $1,587(1,285-1,890)$ & $1,047(647-2,043)$ \\
\hline SY-ASY & \multirow{2}{*}{$0.53(0.46-0.61)$} & $492(373-611)$ & $132(46-630)$ \\
\hline ASY-ASY & & $288(234-341)$ & $101(42-299)$ \\
\hline \multicolumn{4}{|l|}{ Phenotype } \\
\hline Golden-winged Warbler & $0.53(0.46-0.61)$ & $481(413-549)$ & $134(47-582)$ \\
\hline Blue-winged Warbler & $0.61(0.35-0.82)$ & 405 (198-613) & $225(45-432)$ \\
\hline Hybrid & $0.57(0.43-0.70)$ & $590(295-886)$ & $127(47-572)$ \\
\hline \multicolumn{4}{|l|}{ Sex } \\
\hline Male & $0.53(0.46-0.61)$ & $404(340-467)$ & $122(42-448)$ \\
\hline Female & $0.50(0.32-0.67)$ & $716(553-878)$ & $321(77-690)$ \\
\hline \multicolumn{4}{|l|}{ Study area } \\
\hline Northern & $0.50(0.40-0.60)$ & 396 (308-483) & $113(64-306)$ \\
\hline Southern & $0.53(0.46-0.61)$ & $538(450-625)$ & $170(42-629)$ \\
\hline
\end{tabular}




\section{FIGURES}
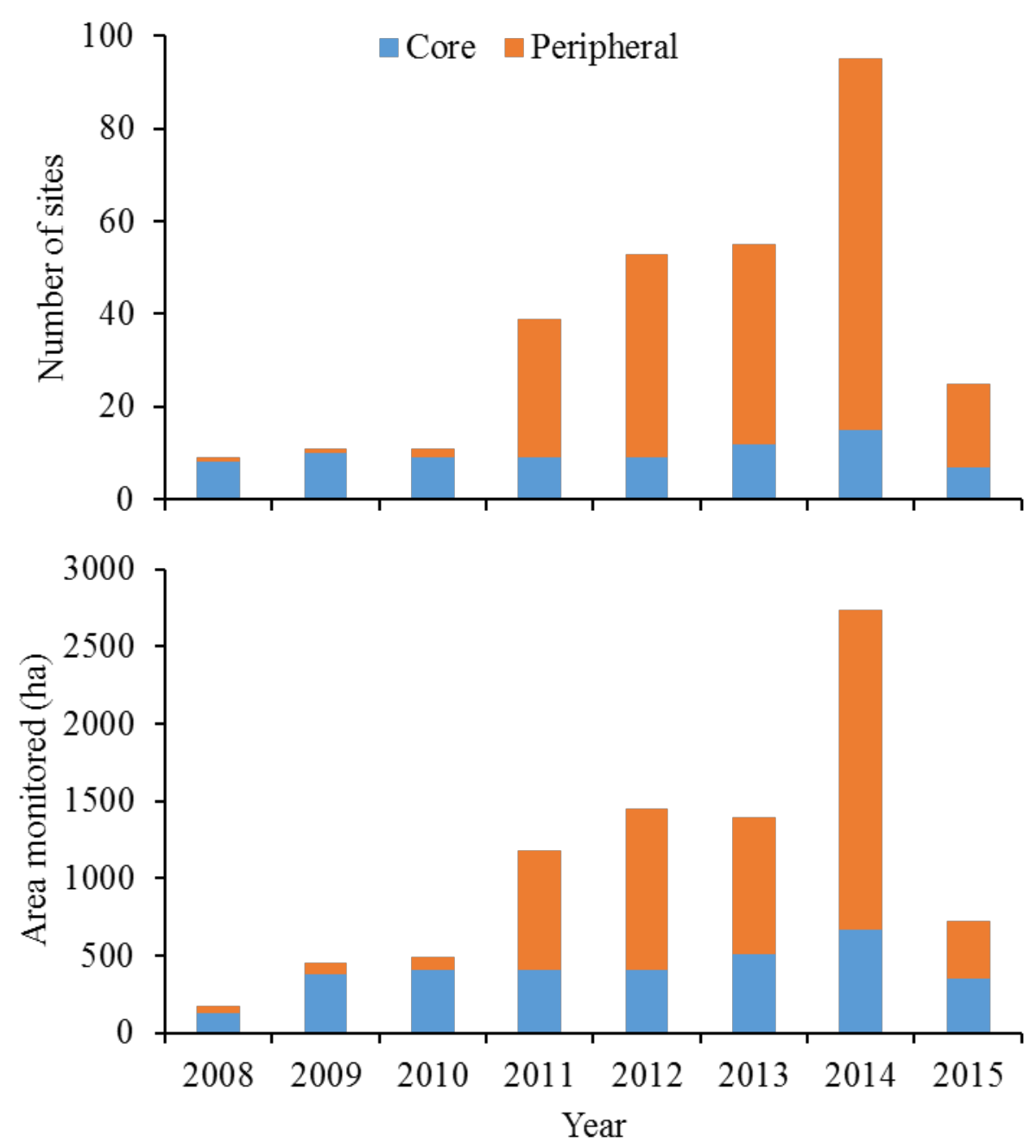

Figure 1. The number of core and peripheral sites and thus the amount (ha) of shrubland cover monitored changed over time during our 2008-2015 study of Golden-winged Warbler annual survival and dispersal in the Allegheny Mountains of West Virginia. 


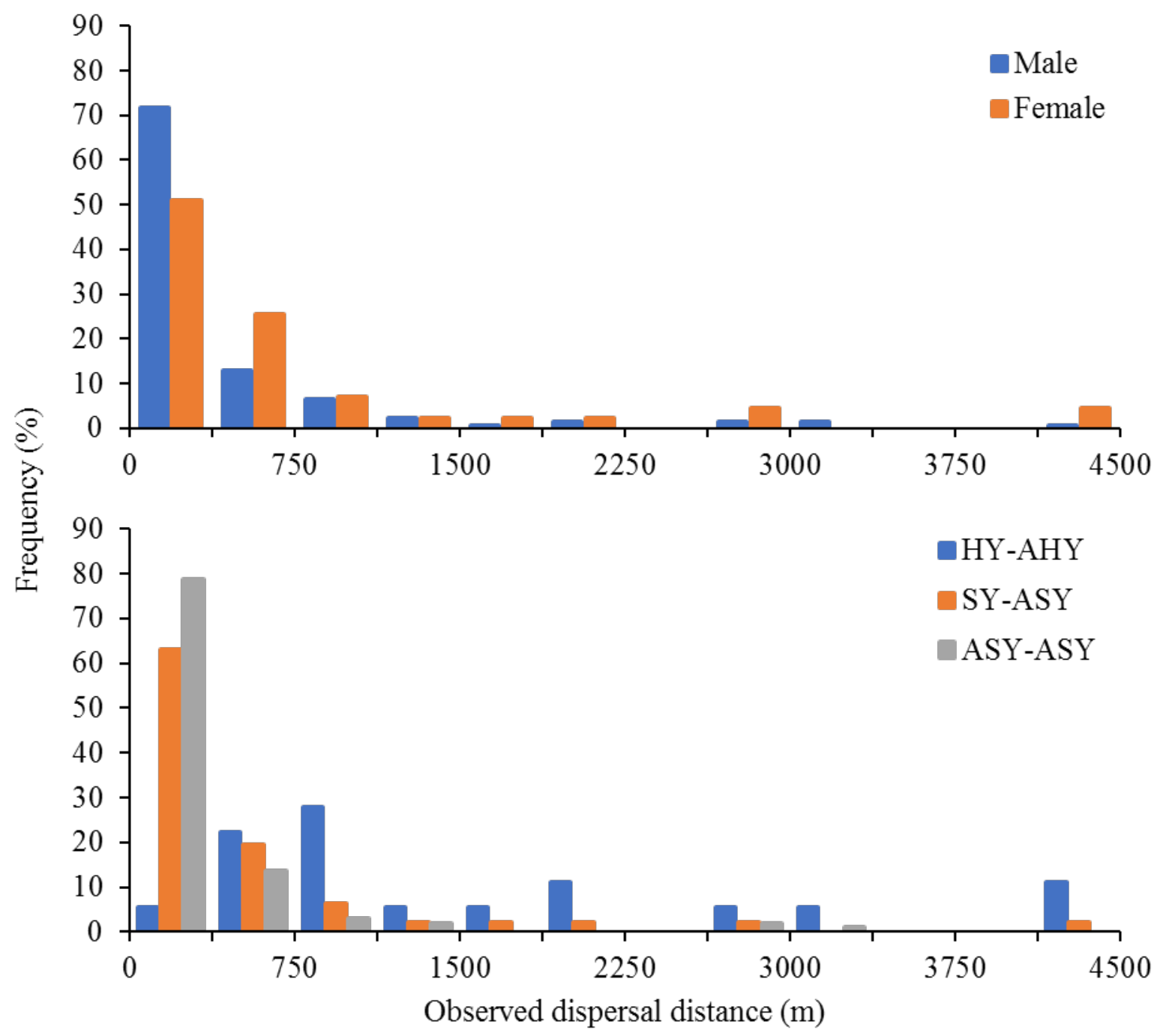

Figure 2. Observed distances of dispersal events for Vermivora warblers by age (HY = hatch year, SY = second year, ASY = after second year) and sex in the Allegheny Mountains of West Virginia during 2008-2015. See Table 2 for summary statistics for dispersal distances. 


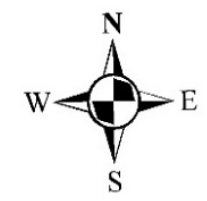

\section{Northern Study Area}

Site

Core
Peripheral

\section{Land cover}

Other

Forest
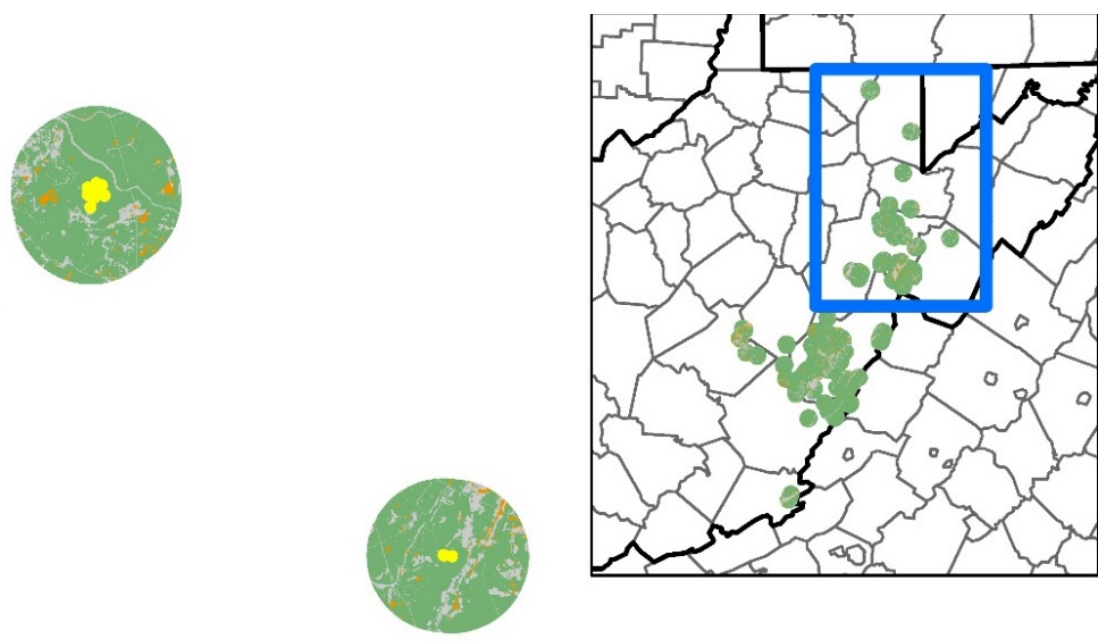

Shrubland and Young Forest

\begin{tabular}{llllll}
0 & 3 & 6 & 12 & 18 & 24 \\
\hline
\end{tabular}
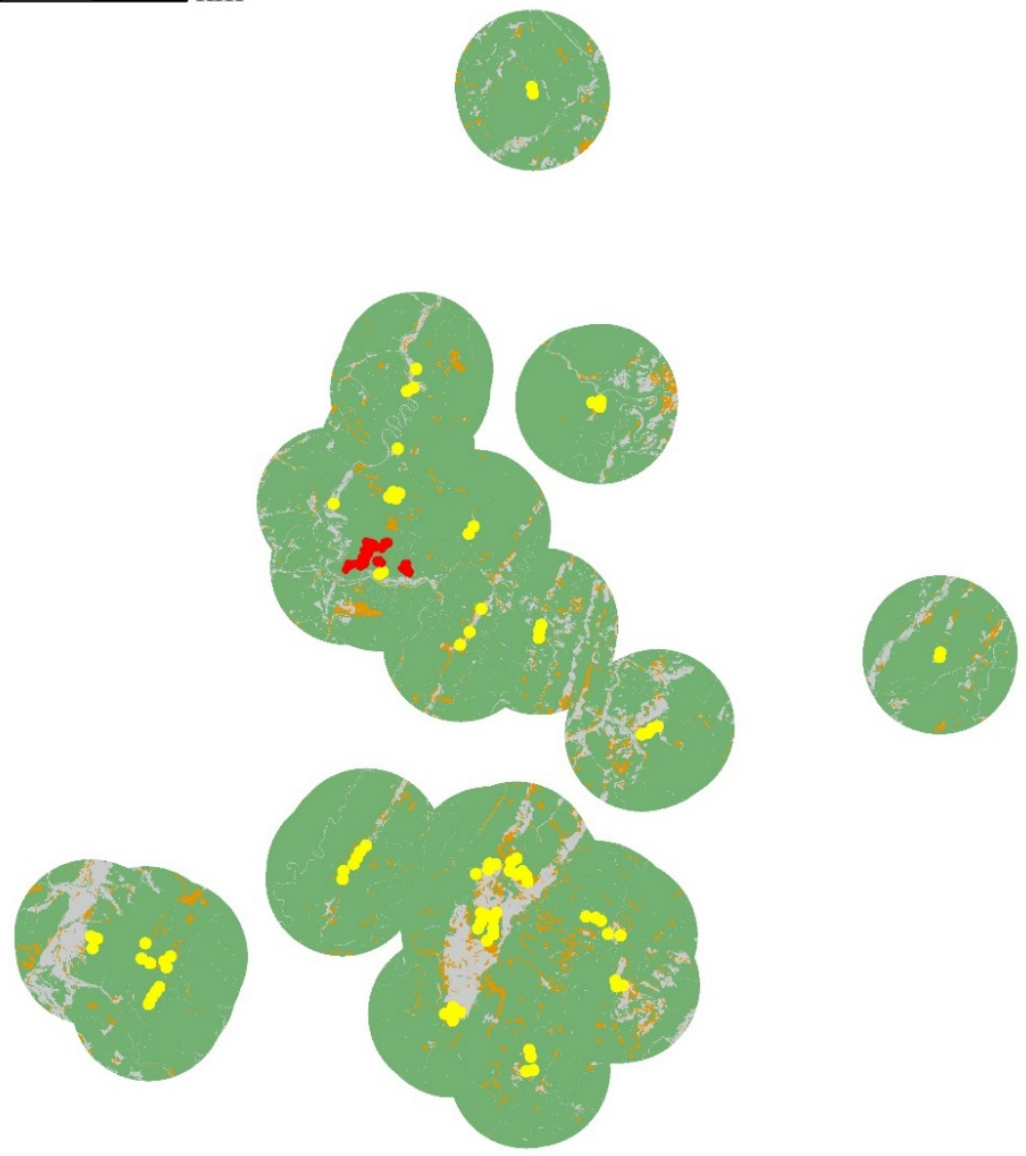

Figure 3. We banded and resighted Vermivora warblers across two study areas in the Allegheny Mountains of West Virginia during 2008-2015. The northern study area (top) had decreasing populations of Golden-winged Warblers, while the southern study area (bottom) had relatively stable populations. 

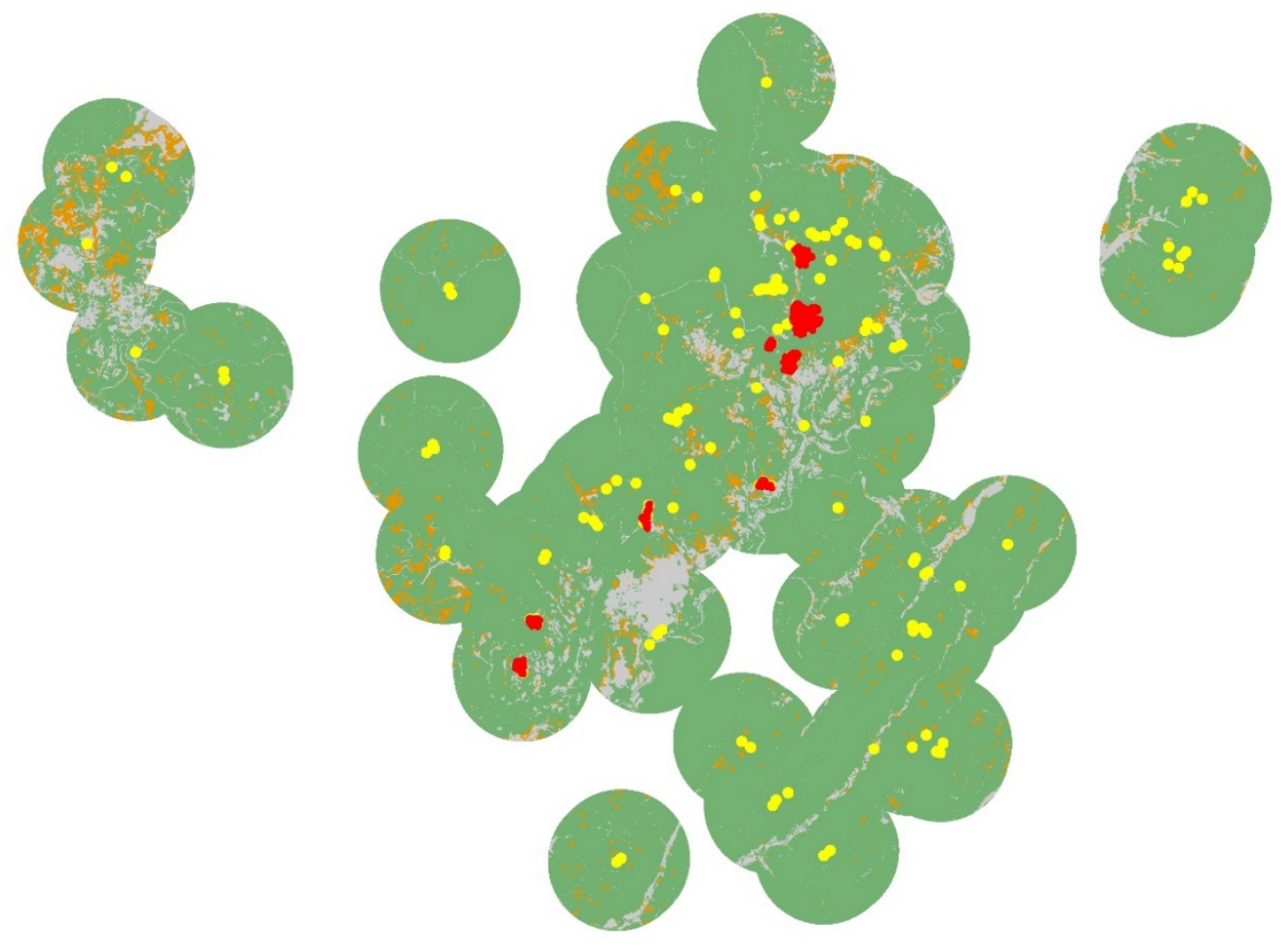<smiles>N=C1C2=C(S)NC1C2=N</smiles>

\section{Southern Study Area}

Site

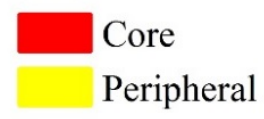

\section{Land cover}

Other

\section{Forest}

Shrubland and Young Forest

\section{\begin{tabular}{lrrrrr}
0 & 3 & 6 & 12 & 18 & 24 \\
\hline
\end{tabular}}
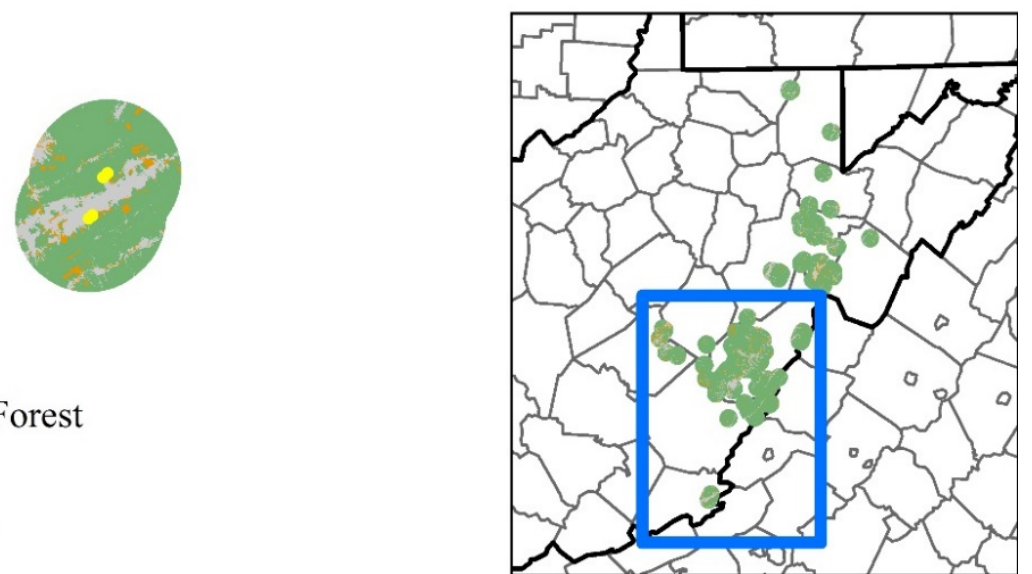

Figure 3 (cont.). We banded and resighted Vermivora warblers across two study areas in the Allegheny Mountains of West Virginia during 2008-2015. The northern study area (top) had decreasing populations of Golden-winged Warblers, while the southern study area (bottom) had relatively stable populations. 


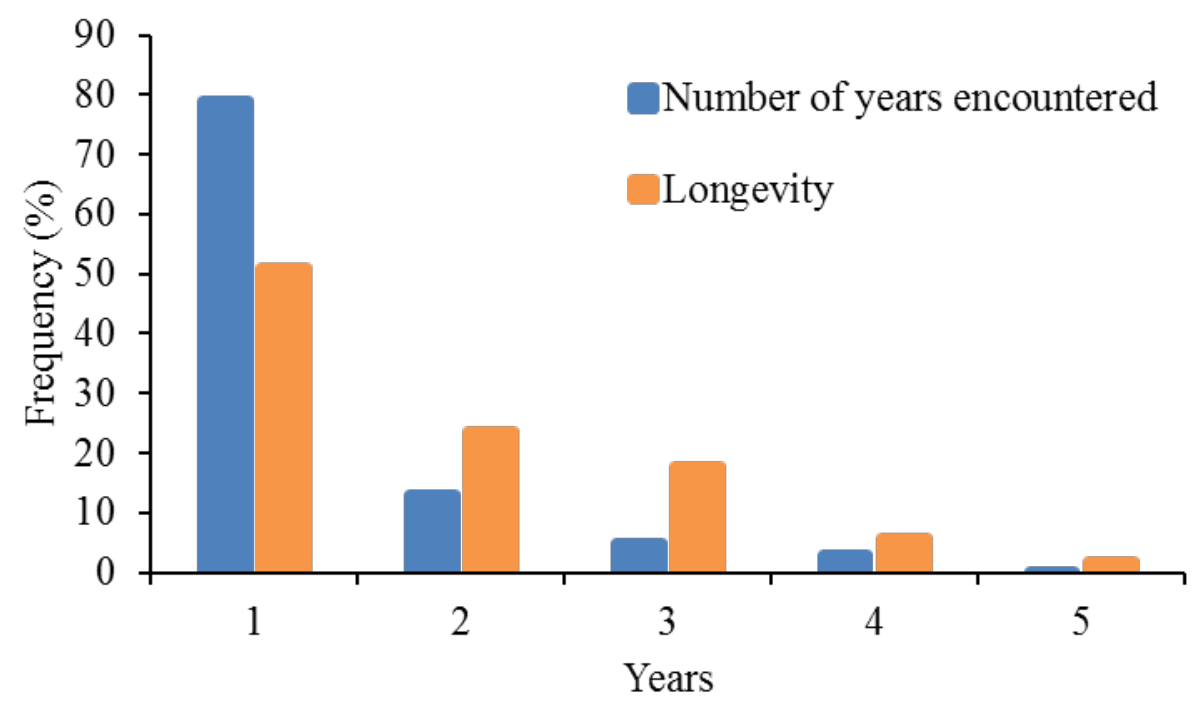

Figure 4. Histogram of years encountered ( $n=517$ warblers) and longevity (age in years, $n=102$ adult warblers with known age at time of banding) of Vermivora warblers in the Allegheny Mountains of West Virginia during 2008-2015. 


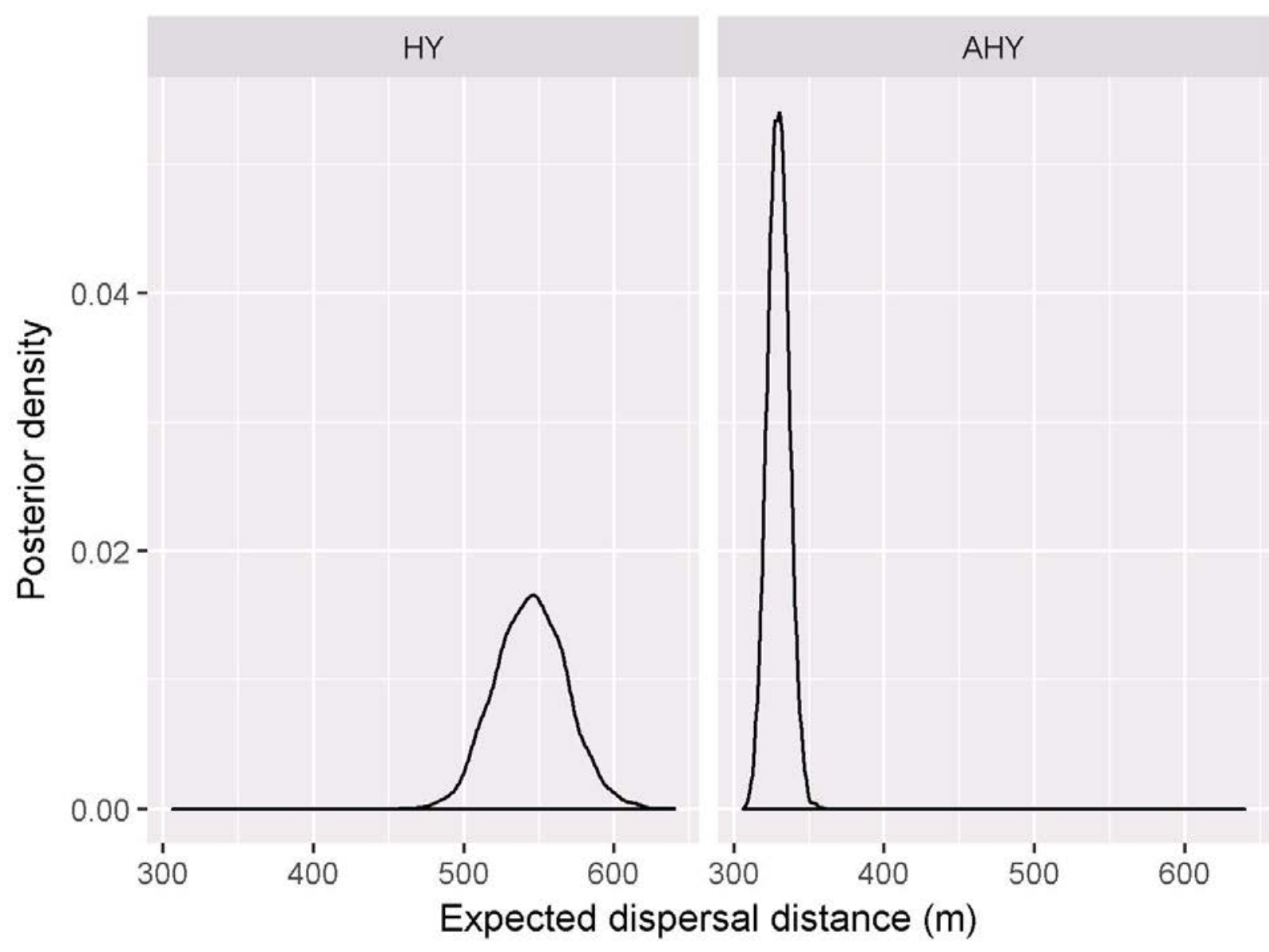

Figure 5. Expected dispersal distances of Vermivora warblers in the Allegheny Mountains of West Virginia during 2008-2015 derived from our spatial Cormack-Jolly-Seber survival model. Posterior mean expected breeding dispersal (AHY) distance was 329 m (95\% confidence interval $[\mathrm{CI}]=316-344 \mathrm{~m})$ and expected natal dispersal $(\mathrm{HY})$ distance was 544 (95\% CI = 500-592 m). The y-axis represents the density, or relative frequency, of expected dispersal distances. 


\title{
CHAPTER 4. GOLDEN-WINGED WARBLERS MAY SELECT NESTING TERRITORIES WITH NON-RANDOM SHRUB COMMUNITY CONFIGURATION
}

\begin{abstract}
Golden-winged Warbler nesting cover is well-studied, yet an objective evaluation of spatial configuration of vegetation components at nest sites and territories remains a persistent knowledge gap. Indeed, studies of the spatial configuration of vegetation components at nest-site or territory scales are uncommon across avian species despite their potential to improve on best management practices for creating nesting cover. Therefore, during 2011-2014 we measured shrub community characteristics at Golden-winged Warbler nests and territories within pastures in Pocahontas and Randolph counties, West Virginia. We also simulated data to represent the full distribution of shrub community configurations available to Golden-winged Warblers. We evaluated nest-site level and territory level selection of edges, degree of shrub aggregation, and shrub cover. Golden-winged Warblers selected nest sites with more shrub cover than random locations but did not select for a particular shrub community configuration for nesting. The species selected territories with more pronounced edges $(\geq 60 \%$ difference in shrub cover on either side of a given point) and a more clumped rather than dispersed or uniform shrub configuration (shrub clumps 4.6-22.6 m wide) than would be expected given a random configuration of shrubs, although selection was relatively weak. Selection for shrub edges and clumps at the territory scale rather than the nest scale despite frequent documentation of Goldenwinged Warblers nesting along edges suggests that the species may be selecting territories that maximize the number of potential nest sites in anticipation of re-nesting up to 3 times after nest failure or to reduce predation risk by way of the potential-prey-site hypothesis. We also evaluated use of vegetation canopy height measured using airborne light detecting and ranging data at a subset of our nests. Golden-winged Warbler nest sites had taller (mean height $=4.3 \mathrm{~m}$ ) and more variable (mean standard deviation of height $=3.1 \mathrm{~m}$ ) vegetation canopy height than random locations (mean height $=2.6$, mean standard deviation of height $=2.1 \mathrm{~m}$ ) within the same territory. Across a Golden-winged Warbler territory, 40-52\% of the tallest vegetation canopy was $\leq 1 \mathrm{~m}$ tall consisting of grasses, forbs, blackberry, and seedlings, 29-33\% of the tallest vegetation canopy was $>1$ to $\leq 5 \mathrm{~m}$ tall consisting of shrubs and saplings, and $15-32 \%$ of the tallest vegetation canopy was $>5$ to $\leq 20 \mathrm{~m}$ tall consisting of trees. Our results improve on
\end{abstract}


existing management recommendations by providing one of the first objective evaluations of the spatial configuration of Golden-winged Warbler nesting cover.

Keywords: edge, clumped, LIDAR, simulation, Vermivora chrysoptera

\section{INTRODUCTION}

Golden-winged Warbler (Vermivora chrysoptera) nesting cover is among the moststudied for any songbird in North America (Klaus and Buehler 2001, Bulluck and Buehler 2008, Roth et al. 2012, Aldinger and Wood 2014, Terhune et al. 2016, McNeil et al. 2017). A common thread among these studies is qualitative descriptions of nesting cover using terms such as “complex”, “diverse”, “edge”, “mosaic”, and "patchy”, which imply high spatial variation of vegetation characteristics. Yet analyses have focused primarily on vegetation metrics that mask spatial arrangement of vegetation (e.g., mean vegetative cover). This discrepancy is important because it highlights a potential knowledge gap about the species' nesting ecology and sends an ambiguous message to land managers wanting to create nesting cover. After all, a management recommendation for a single percent cover value or range of percent cover values across an area (other than $0 \%$ or $100 \%$ ) can result in an infinite number of outcomes in the absence of appropriate spatial context.

The few attempts that have quantified spatial arrangement of vegetation at nest sites have been subjective. For example, a study of Golden-winged Warbler occupancy on abandoned and low-intensity farmland in western Virginia developed a “clumpiness” index to visually assess the spatial arrangement of shrub patches around point count locations, ranging from scattered to contiguous (Bulluck and Harding 2010). Similarly, multiple studies measured distance to a “micro-edge” based on an observer's visual interpretation of any apparent change in vegetation height or composition (Roth et al. 2012, Bakermans et al. 2015, Frantz et al. 2016, Leuenberger et al. 2017). In addition to observer bias, this latter approach is not guided by research on the species' use, preference, or selection of certain edge characteristics within the nesting territory. This is not surprising because edge characteristics within nesting territories are essentially undescribed despite frequent references to the species nesting along edges (e.g., Confer et al. 2011). As with some other studies that have documented the utility of rapid visual assessments for modeling animal populations (Cook and Zack 2008), the “clumpiness” index and distance to micro-edge metrics outperformed other covariates at predicting Golden-winged Warbler 
occupancy (Bulluck and Harding 2010, Leuenberger et al. 2017). While these metrics may provide clearer guidance for conservation planners and land managers than percent cover values alone, subjective indices tend to be imprecise and can lead to unexpected outcomes, including decreases in populations of target species (Gorrod and Keith 2009). Therefore, objective descriptions of the spatial arrangement of vegetation and edge characteristics at Golden-winged Warbler nest sites are needed to improve conservation efforts.

Fortunately, some of the data required to describe spatial arrangement and edge characteristics of Golden-winged Warbler nesting cover already may be available or may be attained with slight modification to frequently used vegetation sampling protocols. For example, line-point intercept transects have been used across the species’ breeding range to quantify vegetative cover at nest sites (Roth et al. 2012). At each point along the transect, an observer records the presence or absence of different types of vegetation (James and Shugart 1970). Recording the spatial position of the data from each point along the transect is a simple modification that can greatly improve the utility of line-point intercept transect data without increasing time or labor (K. R. Aldinger, pers. obs.). Spatially-referenced presences and absences of vegetative cover could allow for spatially-implicit (e.g., runs test for randomness, Wald and Wolfowitz 1943) and spatially-explicit analyses (e.g., point-pattern analysis, Wiegand and Moloney 2014) that would provide still-needed information about size, shape, and arrangement of and distance to vegetation patches at nest sites. Moving forward, the increasing availability of high-spatial resolution airborne light detection and ranging (LIDAR) data further increases our ability to spatially describe Golden-winged Warbler nesting cover. It is surprising that LIDAR has not been used more already in Golden-winged Warbler research (but see Harrelson 2015) because of the level of detail the technology provides in structurally complex vegetation communities (Lefsky et al. 2002). LIDAR may be especially useful for applications involving vegetation height, another metric often subjectively estimated visually and without accounting for potentially important spatial variation (Klaus and Buehler 2001, Bulluck and Buehler 2008, Patton et al. 2010, Aldinger and Wood 2014, Terhune et al. 2016).

Vegetation communities used by Golden-winged Warblers for nesting vary across the species' range (Confer et al. 2011), but shrublands on active and abandoned pastures and surface mines appear to be used most often in West Virginia (Canterbury et al. 1996, Aldinger et al. 2017). On these pastures, shrubs form the patchy structure of Golden-winged Warbler nesting 
cover and serve as important substrates and perches at nest sites (Aldinger and Wood 2014). Shrubs cover an intermediate amount of area within Golden-winged Warbler territories (3846\%, Aldinger and Wood 2014) and can take many possible spatial arrangements. This contrasts with other types of vegetative cover, which individually comprise so little (saplings $=8-9 \%$, vines $=9-10 \%$, canopy trees $=9-12 \%$ ) or so much (grasses $=69-70 \%$, forbs $=80-84 \%$ ) of a Golden-winged Warbler's territory that the complexity of their spatial arrangement is limited (Aldinger and Wood 2014). Furthermore, shrub cover is widely identified as important to breeding Golden-winged Warblers (Confer et al. 2011, Roth et al. 2012). Therefore, we focused on shrub cover in this investigation of Golden-winged Warbler nesting cover.

Our goal was to evaluate objective measurements of shrub communities within Goldenwinged Warbler territories on pastures in West Virginia to improve our understanding of the spatially complex nature of nesting cover. Specifically, we modeled Golden-winged Warbler selection of shrub community characteristics using field-measured and simulated dependent variables of shrub cover, number of patches, and edge magnitude. We compared nest and random plots to evaluate nest-site selection and compared territory plots (i.e., nest and random plots pooled) to simulated plots to evaluate territory selection. We used simulated plots because they allowed us to make inferences about Golden-winged Warbler territory selection in the context of the full distribution of possible shrub community configurations and because we did not have field data representing availability at the pasture-level. These comparisons represented two research questions, respectively: (1) do Golden-winged Warblers select nest sites with a certain shrub community structure compared to the surrounding territory and (2) do Goldenwinged Warblers select territories with random shrub community structure compared to the full distribution of possible shrub configurations? We also examined vegetation height at a subset of Golden-winged Warbler nest and random plots using airborne LIDAR data.

\section{METHODS}

\section{Study Area}

During 2011-2014, we selected active $(n=8)$ and abandoned $(n=7)$ livestock pastures with known breeding populations of Golden-winged Warblers on the Monongahela National Forest $(n=7)$ and private land $(n=8)$ in Pocahontas and Randolph counties, West Virginia. Pocahontas and Randolph counties are 91\% and 90\% forested, respectively (West Virginia 
Division of Forestry 2010). Pastures were 7-176 ha in size, 708-1132 m in elevation, and consisted of a patchy mosaic of grasses, forbs, shrubs, saplings, and scattered canopy trees surrounded by later successional deciduous forest (Figure 1).

\section{Territory Mapping and Nest Searching}

To aid in nest-searching efforts and assignment of social nest paternity, we marked male Golden-winged Warblers during May-June with unique combinations of colored leg bands and mapped their territories by recording observed male locations with global positioning system units (Aldinger and Wood 2015). We captured males in mist nets using conspecific male song playback as an audio lure. We delineated a territory when we observed a male on $\geq 3$ visits over $\geq 8$ visits to a pasture or at a minimum had confirmed nesting in a specific location (Robbins 1970). Only three territory-holding males were not captured and banded during our study and each was the only unbanded male on its respective pasture based on our territory-mapping efforts. Therefore, the lack of colored leg bands served as a unique mark. Delineating territories ( $\mathrm{n}=103$ unique males and 135 territories across years) helped nest searchers target areas frequently visited by males and ultimately would allow us to analytically control for non-independence of vegetation characteristics among nests with the same social nest paternity.

We located Golden-winged Warbler nests $(\mathrm{n}=122)$ during May-June using methods outlined in Martin and Geupel (1993). To reduce the potential bias of discovering a disproportionate number of nests in open vegetation types, we followed behavioral cues of adults such as nest material or food carries, female tzip calls (Ficken and Ficken 1968), male muted song (Highsmith 1989), and inconspicuous movements to areas with nesting cover to discover nests. Golden-winged Warblers usually nest within micro-edges between dense woody cover and herbaceous openings, including fencerows, cattle trails, browse lines, and recently mowed strips on our pastures (Aldinger and Wood 2014). After a nest had been discovered, we traveled along these existing paths and openings during nest monitoring to reduce disturbance to nests and vegetation and to reduce risk of observer-mediated nest depredation (e.g., creating trails to the nest, Martin and Geupel 1993). We monitored nests every 2-4 days initially and more frequently as fledging approached to balance increasing data precision and reducing human disturbance to the nests.

\section{Field Vegetation Data}


Within 49 days (median $=16$ days, interquartile range $(\mathrm{IQR})=7-27$ days $)$ of completion of the nesting attempt, we collected vegetation data at nest plots $(\mathrm{n}=122)$ and spatially-matched random plots $(n=122)$ that were within the same nesting territory. Ninety percent $(n=110)$ of random plots were sampled the same day as the nest (range $=-1-8$ days later). Woody vegetation had reached full leaf development by the time we collected vegetation data (median = 23 June, IQR = 18-26 June, range = 6 June-13 July), but the herbaceous plant community changed rapidly throughout the breeding season due to variation in phenology among individual plant species.

We established random plots matched with each nest by generating a random distance (25-50 $\mathrm{m}$ ) and bearing $\left(0-359^{\circ}\right)$ and measuring from the nest to the center of the random plot using a compass and meter tape. Random plots were constrained to occur within the territorial boundary of the male associated with the nest. We established two 22.6-m line-point intercept transects (hereafter, “transects”) that formed a crosshair over the nest or random plot and extended in the four cardinal directions (i.e., east-west and north-south transects). Thus, pairs of nest and random plots did not overlap, and we avoided placing random plots that would overlap other known nests if the male had multiple nests within his territory that season. We sampled eleven points on each transect with each point separated by $2.26 \mathrm{~m}$ and the center point shared by the two transects. At each point, we recorded the absence (0) or presence (1) of shrub cover by visually assessing if any part of a live shrub intersected a $0^{\circ}$ vertical line extending from the soil surface through the tallest vegetation layer. Observers achieved this by viewing vertically toward the ground and sky using an ocular tube with crosshairs (James and Shugart 1970). We also recorded up to 3 dominant shrub species per nest and random plot using the number of presences on the transects. To break ties, we visually estimated the percent cover of the tied shrub species within an 11.3-m radius of the nest or random plot. We defined shrubs as perennial, multistemmed woody plants usually $<5 \mathrm{~m}$ tall and generally incapable of growing vertically to a height normally associated with mature trees (USDA, NRCS 2017). Shrubs are the dominant structural component at Golden-winged Warbler nest sites on pastures in our study area (Aldinger and Wood 2014). We did not consider blackberry and raspberry (Rubus spp.) as shrubs for this study so that our results would be comparable to other studies that commonly separate Rubus spp. from other woody shrubs (Roth et al. 2012, Leuenberger et al. 2017).

\section{Simulated Vegetation Data}


We also simulated vegetation data (hereafter, "simulated plots”) to be matched with each nest and random plot. To create each simulated plot, we used function sample in package base in program R (R Development Core Team 2017) to randomize the orders of the two 11-digit sequences of 1 s and 0s (i.e., the two transects) of the nest or random plot with which the simulated plot was matched. Thus, simulated plots had the same amount of shrub cover as their respective nest and random plots but could have a different arrangement of shrub presences and absences along the two transects. We used simulated plots because, although they technically are not available to be selected, simulated plots allowed us to make inferences about Golden-winged Warbler territory selection in the context of the full distribution of possible shrub community configurations and because we did not have field data to represent availability at the pasturelevel. From a management perspective, our collective sample of simulated plots represented the breadth of possible configurations that a land manager may produce given guidelines to create a certain amount of shrub cover for Golden-winged Warblers. In all, for each nest that we discovered we had a nest plot, random plot, and 2 simulated plots, each with 2 transects.

\section{LIDAR Data}

The West Virginia University (WVU) Natural Resource Analysis Center (NRAC) collected airborne LIDAR data on 21 June 2012 under contract with the US Forest Service Monongahela National Forest and US Geological Survey West Virginia Cooperative Fish and Wildlife Research Unit to measure Golden-winged Warbler breeding cover. The collection flight was flown at approximately $610 \mathrm{~m}$ above ground level at a mean speed of 135 knots. WVU NRAC actively acquired the data using the Optech ALTM 3100, which can fire up to 100,000 laser pulses per second. Sensors were mounted in a Piper Navajo twin engine aircraft. Pulse rate frequency was 100,000 Hz, scan frequency was $54 \mathrm{~Hz}$, and scan angle was 24 degrees (full field of view). The positional accuracy of these laser returns was $\pm 15 \mathrm{~cm}$ of the vertical axis with at least one laser shot placed every square meter and providing up to four vertical returns. WVU NRAC post-processed the data and classified LIDAR returns as ground, low ( $<1 \mathrm{~m}$ tall), medium (1-3 m tall), and high (>3 m tall) vegetation. LIDAR data encompassed approximately 313 ha covering a subset of two of our pastures in Pocahontas County.

\section{Data Analysis}

Field and simulated vegetation covariates. We derived three metrics for each plot using the two transects: shrub cover, edge magnitude, and number of runs. Shrub cover was the number of 
shrub presences recorded within the plot divided by the total number of points pooling both transects $(\mathrm{n}=21)$. We included shrub cover because most previous studies did not explicitly account for the matched nature of nest and random plots (but see Terhune et al. 2016) nor did they evaluate shrub cover along with other potentially important shrub community covariates (e.g., number of runs or edge magnitude), perhaps contributing to somewhat inconclusive results (Bulluck and Buehler 2008, Aldinger and Wood 2014). Furthermore, including shrub cover in candidate models served as data validation because our simulated plots were generated to have the same shrub cover as nest and random plots.

We needed an objective method to determine whether and how large of a change in shrub cover (i.e., an edge) occurred at a pre-determined location (the center point) within our plots. This problem essentially is change point detection, a realm of statistical analysis usually concerned with identifying variations in time series data or imagery (Aminikhanghahi and Cook 2017). Change point detection can be applied to binary data sequences (Pettitt 1979), but the short length of our transects prohibited reliable change point detection. Pettitt's test for single change point detection can only detect a significant change point when a sequence is $\geq 11$ digits, and with a sequence of 11 digits a significant change point is detected only when transects had a series of 5 consecutive 1s adjacent to a series of 6 consecutive 0s, or vice versa (Pettitt 1979). Therefore, we developed a metric that we called edge magnitude. Edge magnitude was the absolute value of the difference in shrub cover on either side of the center point of each transect. We assigned the maximum value of the two transects for each plot. For example, a plot with transects 11011000000 (shrub cover left of bolded center point is 4 / $5=80 \%$ and right of the center point is 0 / $5=0 \%$ ) and 10100011011 (shrub cover left of the bolded center point is 2 / 5 $=40 \%$ and right of the center point is 4 / $5=80 \%$ ) would have possible edge magnitude values of $|80-0|=80 \%$ and $|40-80|=40 \%$, respectively. The larger of the 2 values, $80 \%$, would be assigned as the edge magnitude for the plot. We hypothesized that nest plots would have a larger edge magnitude than random plots and that territory plots (nest and random plots pooled) would have a larger edge magnitude than simulated plots because Golden-winged Warblers are said to nest along edges (Confer et al. 2011, Aldinger and Wood 2014).

Finally, calculating the number of runs in a binary data sequence is a method of testing the randomness of that sequence (Wald and Wolfowitz 1943). A "run” is a sequence of consecutive equivalent numbers with a new run occurring whenever the number changes. For 
example, the transect 00011110000 has a run of 0 s with a length of 3 , a run of 1 s with a length of 4 , and a run of 0 s with a length of 4 for a total of 3 runs. In the case of our transects, the number of runs is a measure of randomness representing the configuration of shrubs (possible range $=1-$ 11). Smaller values represent a clumped arrangement while larger values represent a dispersed or uniform arrangement. We assigned the mean value of the 2 transects for each plot. We hypothesized that nest plots would have fewer runs than random plots because nests often are located along edges between woody and herbaceous cover (Confer et al. 2011, Aldinger and Wood 2014). Edges would have fewer runs because one side of the transect would be dominated by shrubs (1s) and the other side of the transect would be dominated by herbaceous cover (0s). We also hypothesized that territory plots (nest and random plots pooled) would have fewer runs than simulated plots because Golden-winged Warbler occupancy may be associated with greater aggregation of shrubs on similar sites in Virginia (Bulluck and Harding 2010).

Nest-site and territory selection. We considered selection to be the process by which Goldenwinged Warblers choose nest sites and nesting territories given available resources (Johnson 1980). Selection is the probability that a resource unit (i.e., an area equivalent to $11.3-m$ radius plot) will be used by a Golden-winged Warbler if it is encountered (Lele et al. 2013). To evaluate selection, we used sets of plots matched by social nest paternity, with each set consisting of "cases" (i.e., used plots) and "controls" (i.e., unused plots). Seventy-three unique Golden-winged Warbler males were social fathers across 122 nests during 2011-2014 (mode $=1$ nest per male, range $=1-4$ nests per male per year, range $=1-6$ nests per male across years), resulting in 73 sets of matched plots. This study design is referred to as design III in Manly et al. (2002), where use and availability are measured for each animal. We modeled selection using logistic (logit link) resource selection probability functions (RSPF) with function rspf in R package ResourceSelection (Lele et al. 2017). This approach allowed us to spatially match cases and controls using each nest's social father (Hosmer et al. 2013), which is preferred over unconditional logistic regression because the latter is less powerful and produces biased estimates when matched cases and controls are used (Pike et al. 1980). For low probability events such as the probability of encountering a Golden-winged Warbler nest site at a random location within a territory, results of the RSPF may be interpreted as an approximation of the probability of selection (Keating and Cherry 2004). We considered nests to be low probability events because Golden-winged Warbler territory size on a subset of our pastures averaged $2.4 \pm$ 
0.5 ha (mean \pm standard error [SE], Frantz et al. 2016) and individual nests covered 0.04 ha given an 11.3-m radius. Therefore, even if we assume that a male attempted the maximum number of single-season nests observed in this study $(n=4)$, the combined area of nests would only be 0.16 ha, or $6.7 \%$ of the area of an average territory.

To derive robust parameter estimates and confidence limits (CL) from our RSPF models and to account for unequal sample sizes of nests among Golden-winged Warbler males, we employed an iterative random subsampling routine ( $n=2,000$ replicates). We chose 2,000 subsample replicates to ensure a reasonable amount of computing time while still having $\geq 1,000$ replicates for parameter and CL estimation (Efron and Tibshirani 1993). For each subsample replicate, we randomly drew 1 nest and 1 random plot for each male Golden-winged Warbler because this was the minimum number of nests every Golden-winged Warbler male. For males with nests across multiple years, we drew plots from just one year during each replicate. We then created the associated simulated plots so that simulated plots varied with each subsample replicate. This resulted in replicate datasets with 73 nest plots, 73 random plots, and 146 simulated plots. For each subsample replicate dataset, we also calculated pairwise Pearson’s correlation coefficients among our three covariates to evaluate potential multicollinearity that could arise by including all three covariates in RSPF models. Corresponding to our 2 research questions, we calculated correlation coefficients for the nest-site selection analysis (nest plots vs. random plots) and for the territory selection analysis (territory plots vs. simulated plots) within each subsample replicate. We used function cor in $\mathrm{R}$ package stats to derive correlation coefficients (R Development Core Team 2017). All correlation coefficients had absolute value $\leq 0.4$, suggesting limited multicollinearity. Therefore, we did not exclude or transform any covariates.

We had 2 primary research questions related to resource selection: (1) do Golden-winged Warblers select nest sites with a certain shrub community structure compared to the surrounding territory and (2) do Golden-winged Warblers select territories with random shrub community structure given the full distribution of possible shrub configurations? We developed candidate models representing competing hypotheses for these questions and organized them into model suite 1 representing nest-site selection and model suite 2 representing territory selection. We considered both model suites as representing third-order selection because we were evaluating selection of nest sites and male-defended song territories within the larger home range (Johnson 
1980, Streby et al. 2012, Frantz et al. 2016). Candidate models in model suite 1 used 1 nest plot as a case and 1 random plot as a control per Golden-winged Warbler male to evaluate nest-site selection within territories. Candidate models in model suite 2 used 2 territory plots ( 1 nest and 1 random plot) as cases and 2 simulated plots as controls to evaluate territory selection. Our candidate models for both model suites included all possible combinations of linear terms for shrub cover, number of runs, and edge magnitude because we had only three covariates each of which was potentially associated with Golden-winged Warbler nest-site and territory selection based on our review of published literature. This resulted in 8 candidate models per model suite including the "no selection” model (Lele et al. 2017). We ranked candidate models in each

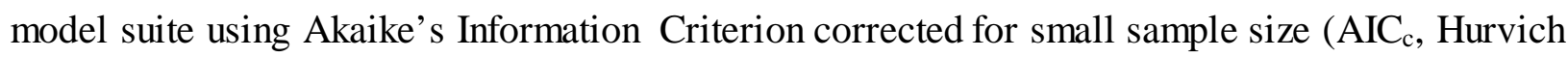
et al. 1998) within R package MuMIn (Barton 2017). We calculated the evidence ratio (E), or the normalized relative likelihood, for all candidate models as $E=e^{(0.5 \Delta \mathrm{AICc})}$, where $\Delta \mathrm{AIC}_{\mathrm{c}}$ is the $\mathrm{AIC}_{\mathrm{c}}$ value of the candidate model minus the minimum $\mathrm{AIC}_{\mathrm{c}}$ value in the model suite (Burnham and Anderson 2002). Given our iterative subsample approach, we first calculated $E$ for all models within each model suite during each subsample replicate, then calculated median $E$ for each model across all replicates. We considered models with median $E \leq 2.7$ to be plausible (Burnham and Anderson 2002, Aldinger et al. 2017). We also calculated the proportion $(M)$ of subsample replicates that each model had $\mathrm{E} \leq 2.7$. We calculated means and 95\% quantile CLs (QCL) for regression coefficients for each model across subsample replicates and considered regression coefficients to be biologically meaningful when the 95\% QCL did not overlap zero. We also created relative frequency histograms to aid in interpretation and management application.

LIDAR covariates. We created a LAS dataset in ArcMap 10.4.1 for Desktop (ESRI 2015) to store and manage LIDAR data (Figure 2). We used the LAS dataset to create a raster digital elevation model (DEM) using LIDAR ground returns (mean spacing of ground returns $\pm \mathrm{SE}=$ $0.93 \pm 0.07 \mathrm{~m}$ ) and a raster digital surface model (DSM) using LIDAR first returns (mean spacing of high vegetation returns $\pm \mathrm{SE}=0.33 \pm 0.01 \mathrm{~m}$ ). We made the DSM cell size two times the mean spacing of high vegetation returns $(0.6 \mathrm{~m} \times 0.6 \mathrm{~m})$ to reduce the number of cells with no returns while maintaining a small cell size to capture the high spatial variation in vegetation heights. A cell size twice the mean point spacing reduced the appearance of "holes" in the DSM where the first return may have missed the vegetation canopy by passing through a small gap in 
the crown of a plant. Such "holes" in the DSM could bias the distribution of vegetation heights toward shorter vegetation. We made the DEM cell size $1.2 \mathrm{~m} \times 1.2 \mathrm{~m}$ so that the cell size would be greater than the mean spacing of ground returns and a factor of the $0.6-\mathrm{m} \times 0.6-\mathrm{m}$ cell size of the DSM. When we had multiple returns per cell, we assigned the maximum elevation of the first returns for the DSM and the mean elevation of the ground returns for the DEM. When cells contained no returns, we used the natural neighbor void fill method to assign an elevation value (ESRI 2015). We subtracted the values of the DEM from the values of the DSM using the raster calculator in ArcMap to derive a canopy height model (CHM) with a 0.6-m × 0.6-m cell size. Vegetation canopy height use. During 2012 when the airborne LIDAR data were collected, we discovered 17 Golden-winged Warbler nests across 10 territories within the two pastures with LIDAR data. Each nest also had an associated random plot $(\mathrm{n}=17) 25-50 \mathrm{~m}$ away within the social father's territory as described above in the Field Vegetation Data section. We recorded the geographic coordinates of nest and random plots using global positioning system units accurate within $3 \mathrm{~m}$. In ArcMap, we made 11.3-m radius buffers around each nest and random plot corresponding with our field vegetation data. Within each buffer, we calculated the mean and standard deviation (SD) of height values from our canopy height model raster. We formulated linear mixed models with function Imer within R package Ime4 (Bates et al. 2017) to compare nest and random plots with regards to the mean and SD of height values within the 11.3-m radius buffers. Because nest and random plots were matched for each male and some males had multiple nests (range 1-3 nests per male), we included a random intercept varying among male ID and a random intercept varying among matched sets of nest and random plot nested within male ID (Bates et al. 2015). We considered results statistically significant at $a=$ 0.05. To increase utility of our results to land managers, we created relative frequency histograms of the canopy heights for each nest and random plot and then averaged relative frequencies across histograms by plot type. The resulting histogram represented cover estimates for vegetation by height class. We divided the histogram into vegetation types, with vegetation $\leq 1 \mathrm{~m}$ tall representing grasses, forbs, Rubus spp., and seedlings ( $0.5-\mathrm{m}$ bin size), $>1$ to $\leq 5 \mathrm{~m}$ tall representing shrubs and saplings (1-m bin size), and $>5$ to $\leq 20 \mathrm{~m}$ tall representing canopy trees (5-m bin size).

\section{RESULTS}




\section{Nest-site and Territory Selection}

In model suite 1 evaluating nest-site selection within Golden-winged Warbler territories, the most-supported model included a single covariate for shrub cover (median $E=1.0$, Table 1 ). Two additional models were plausible (median $E=2.6$ ); however, only the regression coefficient QCL for shrub cover did not overlap zero in these models (Table 1). Across all plausible models, Golden-winged Warblers selected nest sites with more shrub cover compared to random plots

(Figure 3). Across social fathers $(n=73)$, nests (mean $\pm \mathrm{SE}=49.3 \pm 2.3 \%$ ) had $6.4 \pm 2.4 \%$ more shrub cover than random plots (mean $\pm \mathrm{SE}=42.9 \pm 2.9 \%$ ). Golden-winged Warblers did not select for a particular shrub configuration within their territories based on our metrics of edge magnitude and number of runs. Nests and random plots shared a similar composition of shrub species, with hawthorn (Crataegus spp.), multiflora rose (Rosa multiflora), and shrubby St. Johnswort (Hypericum prolificum) as the species most often occurring as one of the top 3 dominant shrubs among both plot types (Table 2).

In model suite 2 evaluating territory selection, the most-supported model included covariates for edge magnitude and number of runs (median $E=1.0$, Table 1 ). Another plausible model included covariates for edge magnitude, number of runs, and shrub cover (median $E=2.6$, Table 1). Regression coefficient QCLs for edge magnitude and number of runs did not overlap zero in both models. The regression coefficient QCL for shrub cover was expected to overlap zero because shrub cover was held constant across sets of matched cases (territory plots) and controls (simulated plots). Golden-winged Warblers selected territories with more pronounced edges (Figure 4) and a more clumped shrub arrangement (i.e., fewer runs) than would be expected given a random configuration of shrubs (Figure 5). However, selection strength was relatively weak and 95\% QCLs around mean probability of selection were broad for both edge magnitude and number of runs. Edges with magnitude $\leq 40 \%$ were less frequent and edges with magnitude $\geq 60 \%$ were more frequent within Golden-winged Warbler territories than simulated data (Figure 6). Run lengths $\leq 2.3$ m (i.e., 1 - 2 consecutive shrub presences) were less frequent and run lengths $\geq 4.6 \mathrm{~m}$ were more frequent within territories compared to simulated data (Figure 7). Sixty percent of the shrub cover occurred in clumps (i.e., $\geq 2$ adjacent shrub presences; Figure 7).

\section{Vegetation Canopy Height Use}


Mean vegetation canopy height within $11.3 \mathrm{~m}$ was significantly taller at nests $($ mean $=$ $4.3 \mathrm{~m}, 95 \% \mathrm{QCL}=2.9 \mathrm{~m}, 5.6 \mathrm{~m}$ ) than at random plots (mean $=2.6 \mathrm{~m}, 95 \% \mathrm{QCL}=1.2 \mathrm{~m}, 3.9 \mathrm{~m}$; Table 3). Standard deviation of vegetation canopy height also was significantly larger at nests (mean $=3.1 \mathrm{~m}, 95 \% \mathrm{QCL}=2.5 \mathrm{~m}, 3.6 \mathrm{~m}$ ) than at random plots (mean $=2.1 \mathrm{~m}, 95 \% \mathrm{QCL}=1.6$ m, $2.7 \mathrm{~m}$; Table 3). Based on the histogram of vegetation height (Figure 8), nest and random plots appeared to differ primarily in cover of vegetation $\leq 0.5 \mathrm{~m}$ tall, likely representing grasses, forbs, Rubus spp., and seedlings, and vegetation $>5 \mathrm{~m}$ tall, likely representing canopy trees.

\section{DISCUSSION}

\section{Nest-site and Territory Selection}

Our results suggest that Golden-winged Warblers selected nest sites based on the amount and not the configuration of shrub cover, favoring locations with higher shrub cover. However, shrub cover within territories overall was not randomly distributed. Attributes long-considered to be associated with nest sites, such as edges between clumps of shrubs and clumps of herbaceous vegetation (Confer et al. 2011), were selected for at the territory scale. Golden-winged Warblers selected nesting territories with more pronounced edges and a more clumped shrub configuration than would be expected give a random configuration of shrubs. Another study in Virginia most comparable to ours similarly found that Golden-winged Warbler occupancy was positively associated with the degree of aggregation of shrubs and saplings based on visual assessment (Bulluck and Harding 2010). Although the two studies had similar results, ours is the first to objectively and rigorously quantify the spatial configuration of vegetation within Golden-winged Warbler nesting territories. Our novel approach advances our understanding of Golden-winged Warbler nesting ecology by addressing a persistent knowledge gap about the importance of spatial arrangement of vegetation. We also improve on existing best management practices for creating and enhancing nesting cover by providing more precise and less subjective estimates of the spatial configuration of habitat components (Golden-winged Warbler Working Group 2013).

Golden-winged Warbler use and selection of shrub cover at the nest-site and territory level have been analyzed extensively (Klaus and Buehler 2001, Patton et al. 2010, Frantz et al. 2016). However, we are aware of only one study of selection that explicitly accounted for matched samples during statistical analysis (Terhune et al. 2016), despite many studies having sampling designs that allowed for matched analysis (Bulluck and Buehler 2008, Roth et al. 2012, 
Aldinger and Wood 2014). Such an analysis is more appropriate and powerful than an unconditional analysis when used and unused locations can logically be matched (Pike 1980, Compton et al. 2002). Terhune et al. (2016) found that Golden-winged Warblers selected nest sites with 15-35\% woody cover (shrubs and saplings) within a 1-m radius. In our study, probability of selecting a location as a nest site was positively associated with shrub cover within an 11.3-m radius. These two studies provide evidence that Golden-winged Warbler nest-site selection varies dramatically depending on spatial scale even within a single order of selection (third-order, Johnson 1980). At a broader 100-m radius scale, Golden-winged Warbler density was positively associated with amount of manually-digitized shrubland cover type (not the amount of area covered by individual shrubs, per se) based on point counts on pastures in West Virginia with peak density occurring at $100 \%$ shrubland cover type (Aldinger et al. 2017). At 1$\mathrm{km}$ and 10-km radius scales, Golden-winged Warbler abundance was negatively associated with edge habitat density (i.e., shrubland cover type) and positively associated with amount of forest cover type (Thogmartin 2010). Crawford et al. (2016) also found a positive association between occurrence and amount of deciduous forest cover type within 2.5-km square grid cells. Collectively, these results suggest that Golden-winged Warblers may select relatively smaller amounts of shrub cover at broad (geographic range, 1-km-10-km radius) and fine scales (nest site microhabitat, 1-m radius) and select relatively larger amounts of shrub cover at intermediate scales (nest site macrohabitat and territories, 11.3-m-100-m radius). Thus, it is important that researchers explicitly identify the spatial scale(s) at which selection occurs and at which the results may be applied by land managers (Pribil and Picman 1997).

Our other shrub metrics, edge magnitude and the number of runs, again demonstrated the importance of appropriate spatial scale and the hierarchical nature of resource selection. Goldenwinged Warblers did not select nest sites with more pronounced edges or fewer runs than the surrounding territory, contrary to our predictions and references to the species nesting along edges and among clumps of shrubs (Confer and Knapp 1981, Confer et al. 2011). This may have been due to the length of our transects (22.6 m), point spacing (2.26 m), and shrub configuration being inherently difficult to quantify. Alternatively, there may actually be no selection for certain shrub configurations at nest sites at the 11.3-m radius scale. This latter alternative has merit because we found evidence that Golden-winged Warblers selected overall nesting territories with more pronounced edges and fewer runs than would be expected given a random shrub 
configuration. Therefore, Golden-winged Warblers may be selecting territories that maximize the number of potential nest sites available perhaps in anticipation of re-nesting up to 3 times after nest failure (Aldinger et al. 2015) or to reduce predation risk by way of the potential-prey-site hypothesis (Martin 1993). Hermit Thrush (Catharus guttatus) may select nest sites in white firs (Abies concolor) with many other white firs nearby to increase the number of potential prey sites that must be searched by potential nest predators (Martin and Roper 1988). For Golden-winged Warblers, who are thought to nest along vegetation edges (Confer et al. 2011, Aldinger and Wood 2014), this means selecting nesting territories with shrub clumps 4.6-22.6 m wide adjacent to similarly-sized areas of non-shrub cover creating a pronounced edge (edge magnitude $\geq 60 \%$ ).

Our results appear to contradict Leuenberger et al. (2017), who found that Goldenwinged Warbler occupancy was negatively associated with distance to micro-edge, with the species occupying territories with distances to micro-edge $<3 \mathrm{~m}$. However, we identified two important distinctions between the two studies that arise from their definition of micro-edge. Leuenberger et al. (2017) defined distance to micro-edge as "any noticeable change in vegetation structure, i.e., change in vegetation height or species composition, such as a transition from grass to shrubs.” First, micro-edges may occur between any vegetation types or even within a single vegetation type, whereas our study focused solely on shrubs. Therefore, the distance to microedge metric is inherently biased to identify a less clumped vegetation structure than our study. Micro-edges may even occur within a clump of shrubs because of changes in shrub height or understory vegetation of a different type, meaning the results of the two studies are not mutually exclusive. Second, the phrase "any noticeable change" makes the metric fundamentally imprecise and difficult to repeat, being dependent on human interpretation and perception. We nonetheless find valuable contributing information in Leuenberger et al. (2017), as the study illustrates the fractal nature of Golden-winged Warbler nesting cover. Complex vegetative patterns repeat at successive spatial scales, with micro-edges (e.g., shrubs of different heights, canopy gaps, interspersion of other vegetation types) occurring within the clumps of shrubs that Golden-winged Warblers selected in our study.

\section{Vegetation Canopy Height Use}

We are aware of only two studies that have objectively measured vegetation height in Golden-winged Warbler nesting territories. In West Virginia, Golden-winged Warblers placed 
nests next to shrubs that were $1.6 \pm 0.1 \mathrm{~m}$ (mean $\pm \mathrm{SE}$ ) tall, compared to randomly-chosen shrubs that were $1.9 \pm 0.2 \mathrm{~m}$ (mean $\pm \mathrm{SE}$ ) tall (Aldinger and Wood 2014). These relatively smaller shrubs adjacent to the nest may provide important perches for entering and leaving the nest and for decoying potential predators (Bradbury 1991, Confer et al. 2011). In Wisconsin, Goldenwinged Warbler territory density was highest in regenerating aspen (Populus spp.) stands where the maximum shrub height was $1.1 \pm 0.3 \mathrm{~m}$ (mean $\pm \mathrm{SE}$ ), although shrubs were not the primary woody structural component as on our pastures (Roth and Lutz 2004). Thus, shrubs $<2$ m tall appear to be an important component of Golden-winged Warbler nesting territories. Yet our results show that vegetation 1-2 m tall comprises only about 5\% of the vegetation canopy area within an 11.3-m radius of nests and within nesting territories. The important distinction here is that we measured the maximum height of the vegetation canopy based on LIDAR first returns (i.e., the tallest vegetation only) while these other two studies measured shrub heights irrespective of their position in the overall vegetative canopy (Roth and Lutz 2004, Aldinger and Wood 2014). Our results based on LIDAR data suggest creating or maintaining vegetation communities within territories with varying heights and overlapping vegetation strata, with an emphasis on maintaining $40-52 \%$ of the territory where the tallest vegetation is $\leq 1 \mathrm{~m}$ tall (i.e., grasses, forbs, and Rubus), 29-33\% where the tallest vegetation is $>1$ to $\leq 5 \mathrm{~m}$ tall (i.e., shrubs and saplings), and 15-32\% where the tallest vegetation is $>5$ to $\leq 20 \mathrm{~m}$ tall (i.e., trees). Total cover of the shorter vegetation classes will be higher because they will occur under taller layers

of vegetation. Within territories, our results also suggest that 11.3-m radius areas with relatively high spatial variation in vegetation canopy height (i.e., juxtaposition of different vegetation canopy heights) may be used as nest sites. Such sites may be selected by Golden-winged Warblers because they maximize reproductive fitness in the face of opposing selection pressures in areas where shrubs form the canopy (high nest survival, low fledgling survival) and areas where trees form the canopy (low nest survival, high fledgling survival; Streby et al. 2014, Lehman 2017).

\section{Management Implications}

Based on a search of the published literature, we found relatively few studies that quantified spatial configuration or arrangement of habitat components at the scale of a bird's territory or smaller (Hunter et al. 1995, Peery et al. 1999, Bulluck and Harding 2010, Leuenberger et al. 2017), compared to the wealth of research done at the landscape level (e.g., 
McGarigal and Marks 1995, Villard et al. 1999, Holzkämper et al. 2006, Fearer et al. 2007, Pellisier et al. 2012). For imperiled species like the Golden-winged Warbler that require increasingly scarce shrubland and young forest cover for nesting (King and Schlossberg 2014), successful conservation undoubtedly hinges on strategic management at landscape and regional levels (Williams et al. 2004, Roth et al. 2012). However, we maintain that local-scale management guidelines remain important because of their ability to influence reproductive fitness (Streby et al. 2014), but particularly because conservation efforts recently have trended towards management on relatively small, privately owned parcels (Ciuzio et al. 2013). Private landowners, perhaps more so than public land managers, may have the ability and desire to follow local-scale recommendations on their land and are likely to highly scrutinize the outcome (Gobster 2001), making science-based territory and patch-scale guidelines critical.

Management guidelines for Golden-winged Warbler nesting territories on active and abandoned pastures in the central Appalachian Mountains may be most effective if focused on an intermediate amount of shrub cover ( $50 \%$ of territory area covered by shrubs) arranged in a clumped configuration with pronounced edges between shrub and non-shrub cover, as well as a high degree of spatial variation in vegetation canopy height and overlap of vegetation strata. Specifically, while solitary shrubs (i.e., run length of 1 ) may be relatively common within territories, $60 \%$ of shrub cover within territories occurred in clumps $2.3-22.6 \mathrm{~m}$ in diameter with each larger-sized clump being less frequent. Combining the clumped configuration of shrubs with the pronounced edges selected by Golden-winged Warblers ( $\geq 60 \%$ edge magnitude), our data suggest managing for shrub clumps 4.6-9.1 m wide adjacent to non-shrub clumps of the same width. Based on related research, individual shrub clumps will provide more benefit if they themselves have a complex arrangement featuring varying shrub sizes and canopy gaps as opposed to a homogeneous clump (Roth et al. 2012, Leuenberger et al. 2017). Finally, our research suggests that it is important to maintain $40-52 \%$ of a Golden-winged Warbler nesting territory where the tallest vegetation canopy is made up of vegetation $\leq 1 \mathrm{~m}$ tall (i.e., grasses, forbs, Rubus, and seedlings), 29-33\% of the territory where the tallest vegetation canopy is made up of vegetation $>1$ to $\leq 5 \mathrm{~m}$ tall (i.e., shrubs and saplings), and $15-32 \%$ of the territory where the tallest vegetation canopy is made up of vegetation $>5$ to $\leq 20 \mathrm{~m}$ tall (i.e., trees). These results do not necessarily deviate from existing management recommendations but provide more objective and spatially-explicit instructions than were previously available for professionals tasked with 
on-the-ground implementation. Future studies with more robust samples of LIDAR data and more rigorous analyses will be important to disentangle the spatial complexities of Goldenwinged Warbler nesting cover.

\section{ACKNOWLEDGMENTS}

The Littlefield family, West Virginia Cooperative Fish and Wildlife Research Unit, and West Virginia Division of Natural Resources Elkins Operation Center provided housing. Numerous private landowners, the USDA Forest Service Monongahela National Forest, and West Virginia Division of Natural Resources allowed access to study sites. We thank J. Aldinger, I. Batterman, P. Bryant, A. Dalton, M. Frantz, N. Glover, J. Kreiser, K. Loucks, S. Malinich, V. Olmstead, C. Roy, J. Saborse, and L. Smith for long hours of work in the field. J. Anderson, J. Jones, J. Lehman, D. J. McNeil, G. Merovich, C. Smalling, M. Strager, R. Tallman, A. Tisdale, and members of the Golden-winged Warbler Working Group provided valuable insights during this research. We also thank S. Lammie for assistance in acquiring LIDAR data. The West Virginia Division of Natural Resources Wildlife Diversity Program (013555.2.1000502W), U.S. Fish and Wildlife Service Migratory Bird Program (F12AP00643), U.S. Forest Service Monongahela National Forest (12-PA-11092100-020), U.S. Natural Resources Conservation Service (68-7482-12-502), and National Fish and Wildlife Foundation (10012877.1.1004706R) granted funding for this research. None of the funders required approval of the manuscript before submission or publication. This study was completed under the auspices of West Virginia University Institutional Animal Care and Use Committee protocols 07-0303 and 10-0201. Any use of trade, firm, or product names is for descriptive purposes only and does not imply endorsement by the U.S. Government.

\section{LITERATURE CITED}

Aldinger, K. R., and P. B. Wood. 2014. Reproductive success and habitat characteristics of Golden-winged Warblers in high-elevation pasturelands. Wilson Journal of Ornithology 126:279-287.

Aldinger, K. R., and P. B. Wood. 2015. Variables associated with detection probability, detection latency, and behavioral responses of Golden-winged Warblers (Vermivora chrysoptera). Condor 117:364-375. 
Aldinger, K. R., P. B. Wood, and C. M. Johnson. 2017. Refined conservation strategies for Golden-winged Warblers in the West Virginia highlands with implications for the broader avian community. Condor 119:762-786.

Aminikhanghahi, S., and D. J. Cook. 2017. A survey of methods for time series change point detection. Knowledge and Information Systems 51:339-367.

Bartoń, K. 2017. MuMIn: Multi-model inference. R package version 1.40.0. https://CRAN.Rproject.org/package=MuMIn.

Bates, D., M. Mächler, B. M. Bolker, and S. C. Walker. 2015. Fitting linear mixed-effects models using lme4. Journal of Statistical Software 67:1-48.

Bates, D., M. Mächler, B. Bolker, and S. Walker. 2017. Linear mixed-effects models using ‘Eigen’ and S4. R package 1.1-14. https://cran.r-project.org/package=lme4.

Bradbury, R. C. 1991. Decoy behavior of Golden-winged Warblers at nest. Bird Observer 19:306.

Bulluck, L. P., and D. A. Buehler. 2008. Factors influencing Golden-winged Warbler (Vermivora chrysoptera) nest-site selection and nest survival in the Cumberland Mountains of Tennessee. Auk 125:551-559.

Bulluck, L. P., and S. Harding. 2010. Golden-winged Warbler patch occupancy and habitat use in Bath and Highlands counties, Virginia. Department of Biology, Virginia Commonwealth University. Richmond, VA, USA.

Burnham, K. P., and D. R. Anderson. 2002. Model selection and multimodel inference: a practical information-theoretic approach, second edition. Springer, New York, NY, USA.

Canterbury, R. A., D. M. Stover, and N. J. Kotesovec, Jr. 1996. Population ecology of Goldenwinged Warblers in southern West Virginia. West Virginia Division of Natural Resources, Elkins, WV, USA.

Ciuzio, E., W. L. Hohman, B. Martin, M. D. Smith, S. Stephens, A. M. Strong, and T. Vercauteren. 2013. Opportunities and challenges to implementing bird conservation on private lands. Wildlife Society Bulletin 37:267-277.

Compton, B. W., J. M. Rhymer, and M. McCollough. 2002. Habitat selection by wood turtles (Clemmys insculpta): an application of paired logistic regression. Ecology 83:833-843.

Confer, J. L., P. Hartman, and A. Roth. 2011. Golden-winged Warbler (Vermivora chrysoptera), version 2.0. In The Birds of North America Online (P. Rodewald, Editor). Cornell Laboratory of Ornithology, Ithaca, NY, USA. https://birdsna.org/SpeciesAccount/bna/species/gowwar.

Cook, H. A., and S. Zack. 2009. Use of standardized visual assessments of riparian and stream condition to manage riparian bird habitat in eastern Oregon. Environmental Management 44:173-184.

Crawford, D. L., R. W. Rohrbaugh, A. M. Roth, J. D. Lowe, S. B. Swarthout, and K. V. Rosenberg. 2016. Landscape-scale habitat and climate correlates of breeding Goldenwinged and Blue-winged warblers. In Golden-winged Warbler Ecology, Conservation, 
and Habitat Management (H. M. Streby, D. E. Andersen, and D. A. Buehler, Editors). Studies in Avian Biology 49:41-66.

Efron, B., and R. J. Tibshirani. 1993. An introduction to the bootstrap. Chapman \& Hall, Boca Raton, FL, USA.

ESRI. 2015. ArcGIS Desktop: Release 10. Environmental Systems Research Institute, Redlands, CA, USA.

Fearer, T. M., S. P. Prisley, D. F. Stauffer, and P. D. Keyser. 2007. A method for integrating the Breeding Bird Survey and Forest Inventory and Analysis databases to evaluate forest bird-habitat relationships at multiple spatial scales. Forest Ecology and Management 243:128-143.

Ficken, M. S., and R. W. Ficken. 1968. Courtship of Blue-winged Warblers, Golden-winged Warblers, and their hybrids. Wilson Bulletin 80:161-172

Frantz, M. W., K. R. Aldinger, P. B. Wood, J. Duchamp, T. Nuttle, A. Vitz, and J. L. Larkin. 2016. Space and habitat use of breeding Golden-winged Warblers in the central Appalachian Mountains. In Golden-winged Warbler Ecology, Conservation, and Habitat Management (H. M. Streby, D. E. Andersen, and D. A. Buehler, Editors). Studies in Avian Biology 49:81-94.

Gobster, P. H. 2001. Human dimensions of early successional landscapes in the eastern United States. Wildlife Society Bulletin 29:474-482.

Golden-winged Warbler Working Group. 2013. Best management practices for Golden-winged Warbler habitats in the Appalachian Region. http://www.gwwa.org/plan.

Gorrod, E. J., and D. A. Keith. 2009. Observer variation in field assessments of vegetation condition: implications for biodiversity conservation. Ecological Management and Restoration 10:31-40.

Harrelson, J. A. 2015. Golden-winged Warblers (Vermivora chrysoptera) of the southern Appalachians: behavior, ecology, and conservation of a declining Neotropical migrant songbird. Master's thesis, Western Carolina University, Cullowhee, NC, USA.

Highsmith, R. T. 1989. The singing behavior of Golden-winged Warblers. Wilson Bulletin 101:36-50.

Holzkämper, A., A. Lausch, and R. Seppelt. 2006. Optimizing landscape configuration to enhance habitat suitability for species with contrasting habitat requirements. Ecological Modelling 198:277-292.

Hosmer, D. W., S. Lemeshow, R. X. Sturdivant. 2013. Applied logistic regression. John Wiley \& Sons, New York, NY, USA.

Hunter, J. E., R. J. Gutiérrez, A. B. Franklin. 1995. Habitat configuration around Spotted Owl sites in northwestern California. Condor 97:684-693.

Hurvich, C. M., J. S. Simonoff, and C. L. Tsai. 1998. Smoothing parameter selection in nonparametric regression using an improved Akaike information criterion. Journal of the Royal Society B 60:271-293. 
James, F. C., and H. H. Shugart, Jr. 1970. A quantitative method of habitat description. Audubon Field Notes 24:727-736.

Johnson, D. H. 1980. The comparison of usage and availability measurements for evaluating resource preference. Ecology 61:65-71.

Keating, K. A., and S. Cherry. 2004. Use and interpretation of logistic regression in habitatselection studies. Journal of Wildlife Management 68:774-789.

King, D. I., and S. Schlossberg. 2014. Synthesis of the conservation value of the early-succession stage in forests of eastern North America. Forest Ecology and Management 324:186-195.

Klaus, N. A., and D. A. Buehler. 2001. Golden-winged Warbler breeding habitat characteristics and nest success in clearcuts in the southern Appalachian Mountains. Wilson Bulletin 113:297-301.

Lefsky, M. A., W. B. Cohen, G. G. Parker, and D. J. Harding. 2002. Lidar remote sensing for ecosystem studies. BioScience 52:19-30.

Lehman, J. A. 2017. Survival and habitat selection of Golden-winged Warblers (Vermivora chrysoptera) during nesting and post-fledging periods at North Cumberland Wildlife Management Area, Tennessee. Master’s thesis, University of Tennessee, Knoxville, TN, USA.

Lele, S. R., J. L. Keim, and P. Sólymos. 2017. Resource selection (probability) functions for useavailability data. $\mathrm{R}$ package version $0.3-2$. https://cran.rproject.org/package=ResourceSelection.

Lele, S. R., E. H. Merrill, J. Keim, and M. S. Boyce. 2013. Selection, choice, use, and occurrence: clarifying concepts in resource selection studies. Journal of Animal Ecology 82:1183-1191.

Leuenberger, W., D. J. McNeil, J. Cohen, and J. L. Larkin. 2017. Characteristics of Goldenwinged Warbler territories in plant communities associated with regenerating forest and abandoned agricultural fields. Journal of Field Ornithology 88:169-183.

Manly, B. F. J., L. L. McDonald, D. L. Thomas, T. L. McDonald, and W. P. Erickson. 2002. Resource selection by animals: statistical design and analysis for field studies, $2^{\text {nd }}$ edition. Kluwer Academic, Dordrecht, Netherlands.

Martin, T. E. 1993. Nest predation and nest sites. BioScience 8:523-532.

Martin, T. E., and G. R. Geupel. 1993. Nest-monitoring plots: methods for locating nests and monitoring success. Journal of Field Ornithology 64:507-519.

Martin, T. E., and J. J. Roper. 1988. Nest predation and nest-site selection of a western population of the Hermit Thrush. Condor 90:51-57.

McGarigal, K., and B. J. Marks. 1995. FRAGSTATS: spatial pattern analysis program for quantifying landscape structure. General Technical Report PNW-GTR-351. U.S. Department of Agriculture, Forest Service, Pacific Northwest Research Station, Portland, OR, USA.

McNeil, D. J., K. R. Aldinger, M. H. Bakermans, J. A. Lehman, A. C. Tisdale, J. A. Jones, P. B. Wood, D. A. Buehler, C. G. Smalling, L. Siefferman, and J. L. Larkin. 2017. An 
evaluation and comparison of conservation guidelines for an at-risk migratory songbird. Global Ecology and Conservation 9:90-103.

Patton, L. L., D. S. Maehr, J. E. Duchamp, S. Fei, J. W. Gassett, and J. L. Larkin. 2010. Do the Golden-winged Warbler and Blue-winged Warbler exhibit species-specific differences in their breeding habitat use? Avian Conservation and Ecology 5:2.

Peery, M. Z., R. J. Gutiérrez, and M. E. Seamans. 1999. Habitat composition and configuration around Mexican Spotted Owl nest and roost sites in the Tularosa Mountains, New Mexico. Journal of Wildlife Management 63:36-43.

Pellisier, V., M. Cohen, A. Boulay, and P. Clergeau. 2012. Birds are also sensitive to landscape composition and configuration within the city centre. Landscape and Urban Planning 104:181-188.

Pettitt, A. N. 1979. A non-parametric approach to the change point problem. Journal of the Royal Statistical Society Series C (Applied Statistics) 28:126-135.

Pike, M. C., A. P. Hill, P. G. Smith. 1980. Bias and efficiency in logistic analyses of stratified case-control studies. International Journal of Epidemiology 9:89-95.

Pribil, S., and J. Picman. 1997. The importance of using the proper methodology and spatial scale in the study of habitat selection by birds. Canadian Journal of Zoology 75:18351844.

R Development Core Team. 2017. R: A language and environment for statistical computing. Version 3.4.2. R Foundation for Statistical Computing. Vienna, Austria. www.rproject.org.

Robbins, C. S. 1970. An international standard for a mapping method in bird census work. International Bird Census Committee. Audubon Field Notes 24:722-726.

Roth, A. M., and S. Lutz. 2004. Relationship between territorial male Golden-winged Warblers in managed aspen stands in northern Wisconsin, USA. Forest Science 50:153-161.

Roth, A. M., R. W. Rohrbaugh, K. R. Aldinger, M. H. Bakermans, S. Barker Swarthout, D. A. Buehler, J. L. Confer, D. Crawford, C. Friis, R. M. Fowlds, J. L. Larkin, J. Loegering, J. D. Lowe, M. Piorkowski, K. V. Rosenberg, C. Smalling, T. M. Terhune, R. Vallender, T. Will, and P. B. Wood. 2012. Golden-winged Warbler breeding season conservation plan. In Golden-winged Warbler Status Review and Conservation Plan (A. M. Roth, R. W. Rohrbaugh, T. Will, and D. A. Buehler, Editors). www.gwwa.org/plan.

Streby, H. M., J. P. Loegering, and D. E. Andersen. 2012. Spot-mapping underestimates songterritory size and use of mature forest by breeding Golden-winged Warblers in Minnesota, USA. Wildlife Society Bulletin 36:40-46.

Streby, H. M., J. M. Refsnider, S. M. Peterson, and D. E. Andersen. 2014. Retirement investment theory explains patterns in songbird nest-site choice. Proceedings of the Royal Society B 281:20131834.

Terhune II, T. M., K. R. Aldinger, D. A. Buehler, D. J. Flaspohler, J. L. Larkin, J. P. Loegering, K. L. Percy, A. M. Roth, C. Smalling, and P. B. Wood. 2016. Golden-winged Warbler nest-site habitat selection. In Golden-winged Warbler Ecology, Conservation, and Habitat 
Management (H. M. Streby, D. E. Andersen, and D. A. Buehler, Editors). Studies in Avian Biology 49:109-125.

Thogmartin, W. E. 2010. Modeling and mapping Golden-winged Warbler abundance to improve regional conservation strategies. Avian Conservation and Ecology 5:12.

USDA, NRCS. 2017. The PLANTS database (https://plants.usda.gov, 4 November 2017). National Plant Data Team, Greensboro, NC, USA.

Villard, M. A., M. K. Trzcinski, and G. Merriam. 1999. Fragmentation effects on forest birds: relative influence of woodland cover and configuration on landscape occupancy. Conservation Biology 13:774-783.

Wald, A., and J. Wolfowitz. An exact test for randomness in the non-parametric case based on serial correlation. Annals of Mathematical Statistics 14:378-388.

West Virginia Division of Forestry. 2010. West Virginia statewide forest resource assessment. West Virginia Division of Forestry, Charleston, WV, USA. http://www.wvforestry.com/DOF100Assessment_Revised_091310_Part1.pdf.

Wiegand, T., and K. A. Moloney. 2014. Handbook of spatial point-pattern analysis in ecology. Chapman and Hall, Boca Raton, FL, USA.

Williams, C. K., F. S. Guthery, R. D. Applegate, and M. J. Peterson. 2004. The northern bobwhite decline: scaling our management for the twenty-first century. Wildlife Society Bulletin 32:861-869. 


\section{TABLES}

Table 1. Model selection results for Golden-winged Warbler nest-site selection and territory selection on pastures in West Virginia during 2011-2014. Models with median $E \leq 2.7$ were plausible. We also calculated the proportion $(M)$ of subsample replicates (n = 2,000) in which each model was considered plausible. Regression coefficients from plausible models that were considered biologically important (i.e., quantile confidence limit did not overlap zero) are bolded.

\begin{tabular}{|c|c|c|c|c|c|}
\hline Model suite & $E$ & $M$ & Edge magnitude & Number of runs & Shrub cover \\
\hline \multirow[t]{8}{*}{ I: Nest-site selection } & $1.0 \mathrm{E}+00$ & 90.9 & -- & -- & $0.311(0.080,2.549)$ \\
\hline & $2.6 \mathrm{E}+00$ & 54.1 & $0.031(-0.009,0.422)$ & -- & $0.320(0.016,2.633)$ \\
\hline & $2.6 \mathrm{E}+00$ & 54.1 & -- & $0.028(-2.222,9.837)$ & $0.417(0.082,3.011)$ \\
\hline & $3.9 \mathrm{E}+00$ & 29.9 & $0.071(-0.034,0.630)$ & $1.240(-2.481,19.471)$ & $0.274(0.012,2.674)$ \\
\hline & $1.6 \mathrm{E}+01$ & 16.8 & $0.241(0.016,1.932)$ & $5.728(0.098,57.429)$ & -- \\
\hline & $5.5 \mathrm{E}+01$ & 4.4 & $0.017(0.009,0.035)$ & -- & -- \\
\hline & $9.4 \mathrm{E}+01$ & 0.5 & -- & $19.729(0.240,184.808)$ & -- \\
\hline & $1.1 \mathrm{E}+02$ & 1.4 & -- & -- & -- \\
\hline \multirow[t]{8}{*}{ II: Territory selection } & $1.0 \mathrm{E}+00$ & 89.3 & $0.024(0.012,0.036)$ & $-0.607(-1.231,-0.441)$ & -- \\
\hline & $2.6 \mathrm{E}+00$ & 60.2 & $0.022(0.001,0.037)$ & $-0.880(-1.835,-0.455)$ & $0.022(-0.005,0.090)$ \\
\hline & $3.6 \mathrm{E}+01$ & 23.5 & -- & $-1.416(-2.096,-0.941)$ & $0.052(0.014,0.109)$ \\
\hline & $2.2 \mathrm{E}+02$ & 4.5 & -- & $-1.148(-1.829,-0.715)$ & -- \\
\hline & $4.0 \mathrm{E}+07$ & 0.0 & $0.029(0.020,0.039)$ & -- & -- \\
\hline & $1.1 \mathrm{E}+08$ & 0.0 & $0.029(0.020,0.039)$ & -- & $-0.001(-0.007,0.004)$ \\
\hline & $4.5 \mathrm{E}+13$ & 0.0 & -- & -- & -- \\
\hline & $3.5 \mathrm{E}+14$ & 0.0 & -- & -- & $0.000(0.000,0.000)$ \\
\hline
\end{tabular}


Table 2. Shrub species at Golden-winged Warbler nests $(\mathrm{n}=122)$ and random plots $(\mathrm{n}=122)$ within territories on pastures in West Virginia during 2011-2014 based on line-point intercept transects.

\begin{tabular}{llrr}
\hline & & \multicolumn{2}{c}{ Frequency of occurrence (\%) ${ }^{1}$} \\
\cline { 2 - 4 } Common name & Scientific name & Nest & Random \\
\hline Hawthorn & Crataegus spp & 95 & 92 \\
Multiflora rose & Rosa multiflora & 75 & 71 \\
Shrubby St. Johnswort & Hypericum prolificum & 34 & 30 \\
Autumn olive & Elaeagnus umbellata & 29 & 29 \\
Witch hazel & Hamamelis virginiana & 11 & 4 \\
Common elderberry & Sambucus canadensis & 8 & 7 \\
Greenbrier & Smilax spp & 5 & 8 \\
Honeysuckle & Lonicera spp & 4 & 11 \\
Spicebush & Lindera benzoin & 3 & 4 \\
Mapleleaf viburnum & Viburnum acerifolium & 2 & 2 \\
Japanese barberry & Berberis thunbergii & 0 & 1 \\
Spiraea & Spiraea spp & 0 & 1 \\
Blueberry & Vaccinium spp & 0 & 2 \\
\hline
\end{tabular}

${ }^{1}$ Number of times shrub species was present as top three dominant shrub divided by total number of nest $(n=122)$ or random plots $(n=122)$. 
Table 3. Vegetation canopy height was taller (mean) and exhibited more variation (standard deviation) at Golden-winged Warbler nests $(n=17)$ compared to random plots $(n=17)$ within the surrounding territory measured in Pocahontas County, West Virginia during 2012. We used linear mixed models with fixed effect for plot type (nest or random), a random intercept varying among male ID $(n=10)$, and a random intercept varying among matched sets of nest and random plots nested within male ID. We considered results statistically significant at $a=0.05$.

\begin{tabular}{|c|c|c|c|c|c|c|c|c|}
\hline \multirow{2}{*}{$\begin{array}{l}\text { Vegetation } \\
\text { canopy } \\
\text { height } \\
\text { model }\end{array}$} & \multirow[t]{2}{*}{$\begin{array}{l}\text { Fixed } \\
\text { effect }\end{array}$} & \multirow[t]{2}{*}{ Estimate } & \multirow[t]{2}{*}{$\begin{array}{l}\text { Standard } \\
\text { error }\end{array}$} & \multirow[t]{2}{*}{$t$} & \multirow[t]{2}{*}{$P$} & \multicolumn{3}{|c|}{$\begin{array}{c}\text { Random effect standard } \\
\text { deviation }\end{array}$} \\
\hline & & & & & & $\begin{array}{c}\text { Male } \\
\text { ID }\end{array}$ & $\begin{array}{l}\text { Matched } \\
\text { set ID }\end{array}$ & Residual \\
\hline \multirow[t]{2}{*}{ Mean } & Intercept & 4.3 & 0.7 & 6.4 & $<0.001$ & 1.5 & 0.5 & 1.6 \\
\hline & $\begin{array}{l}\text { Plot type: } \\
\text { Random }\end{array}$ & -1.7 & 0.6 & -3.0 & 0.009 & & & \\
\hline \multirow{2}{*}{$\begin{array}{l}\text { Standard } \\
\text { deviation }\end{array}$} & Intercept & 3.1 & 0.3 & 11.8 & $<0.001$ & 0.0 & 0.5 & 0.9 \\
\hline & $\begin{array}{l}\text { Plot type: } \\
\text { Random }\end{array}$ & -0.9 & 0.3 & -3.0 & 0.009 & & & \\
\hline
\end{tabular}




\section{FIGURES}

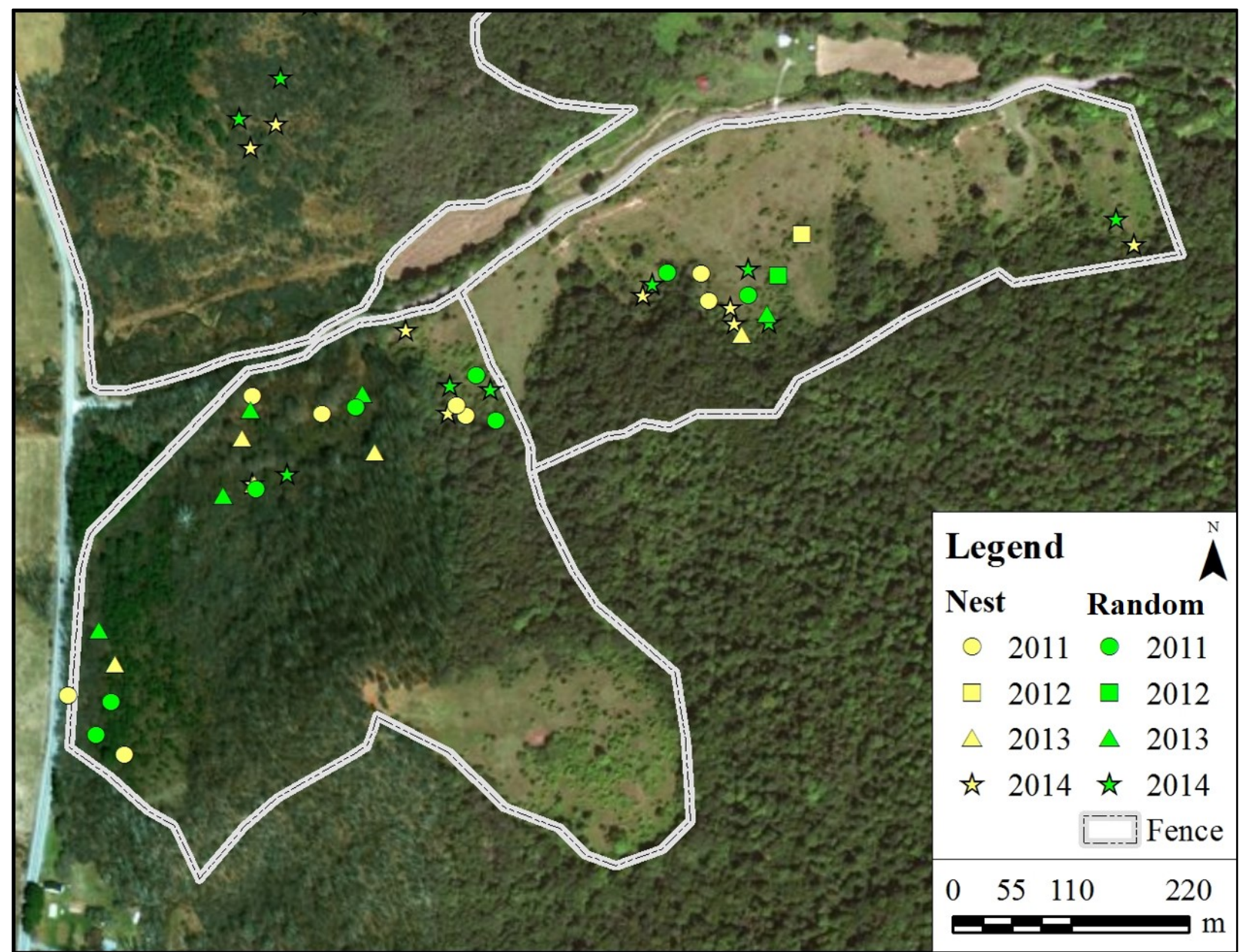

Figure 1. During 2011-2014, we collected vegetation data at Golden-winged Warbler nests (n = $122)$ and random plots $(n=122)$ within pastures $(n=15)$ in Pocahontas and Randolph counties, West Virginia. Golden-winged Warblers generally nested within shrub-dominated areas adjacent to later successional forest, as shown above in one of our pastures on the Monongahela National Forest in Pocahontas County. 

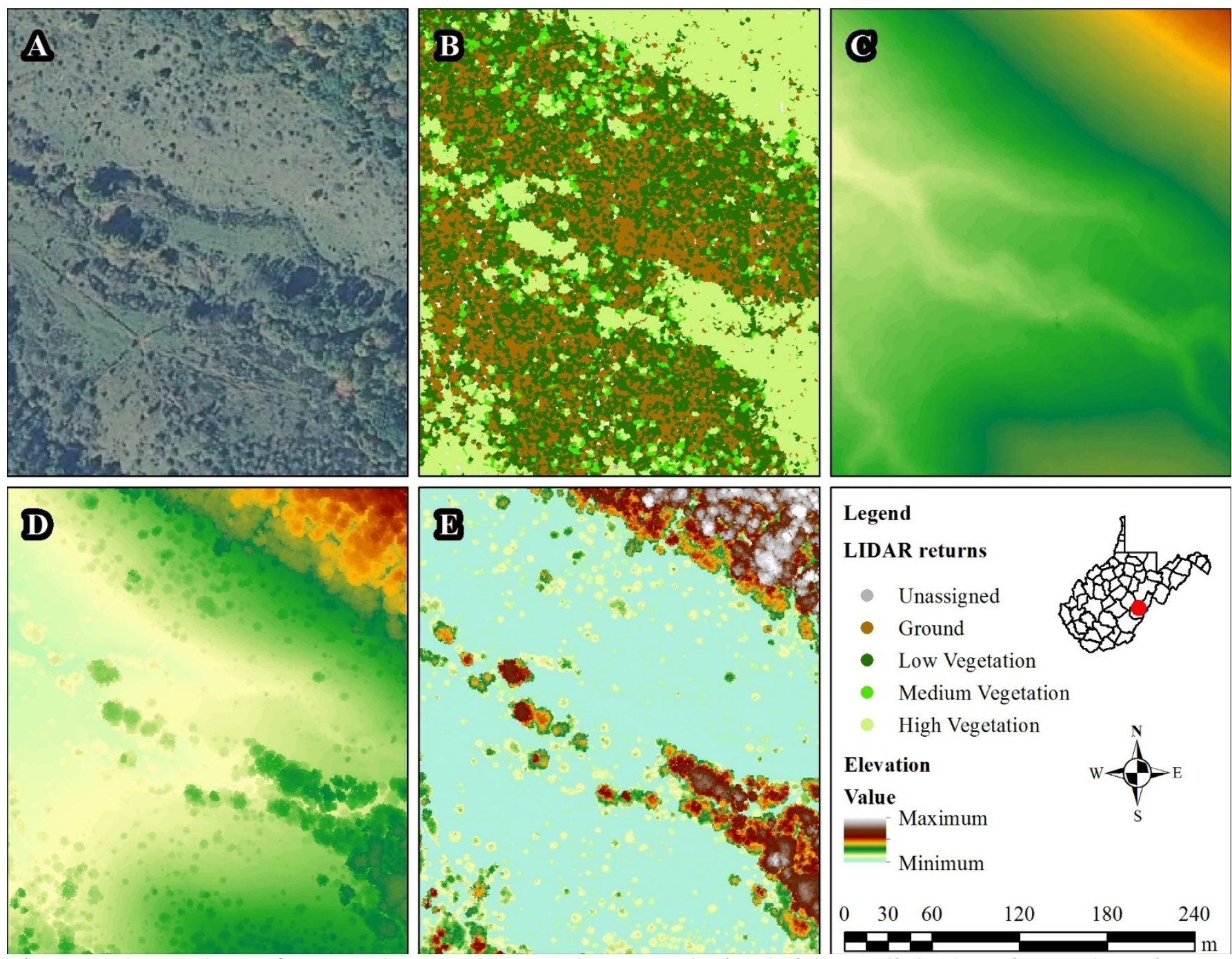

Figure 2. On a subset of two cattle pastures (panel A), we obtained airborne light detection and ranging (LIDAR) data (panel B) to quantify vegetation canopy height within Golden-winged Warbler territories in West Virginia during 2012. We used LIDAR data to derive a digital elevation model (DEM, range $=917-1,179 \mathrm{~m}$, panel C) using ground laser returns and a digital surface model (DSM, range $=919-1,199 \mathrm{~m}$, panel D) using first laser returns. We subtracted the DEM from the DSM to derive a canopy height model (CHM, range $=0-37 \mathrm{~m}$, panel $\mathrm{E}$ ) that was used in vegetation canopy use modeling. 


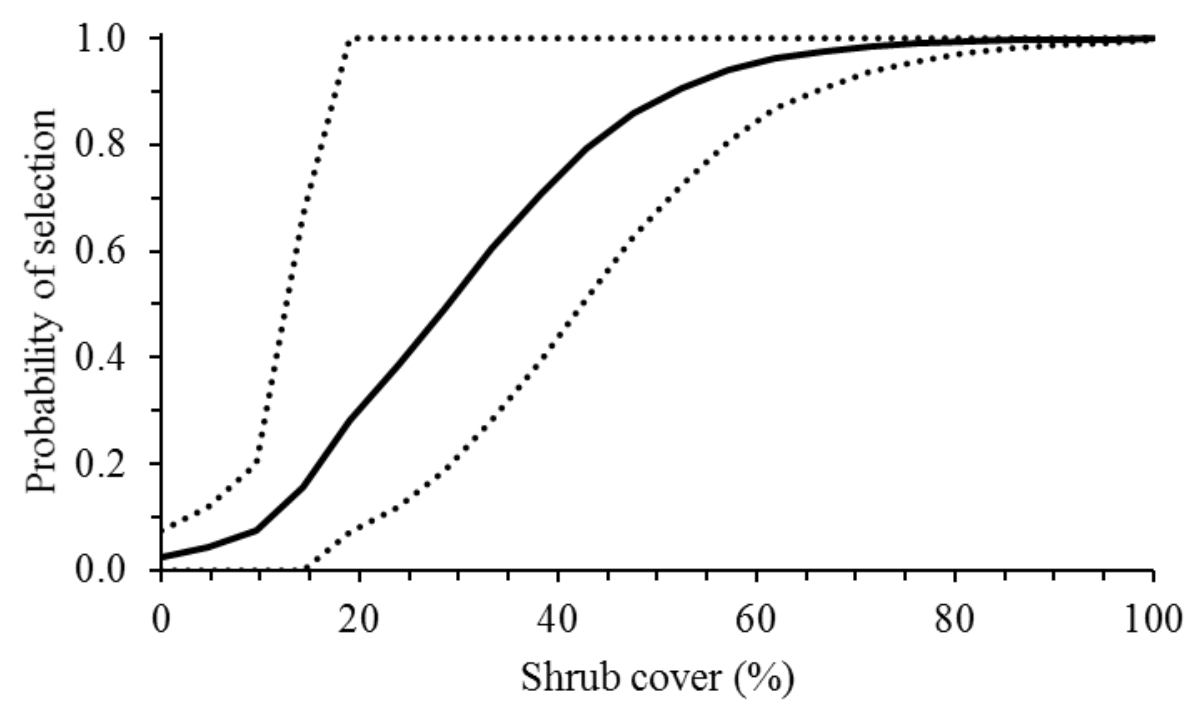

Figure 3. Golden-winged Warblers selected nest sites with higher shrub cover within $11.3 \mathrm{~m}$ compared to the surrounding territory on pastures in West Virginia during 2011-2014. We did not find evidence of selection for a particular shrub community configuration based on edge magnitude and number of runs at nest sites compared to the surrounding territory. 


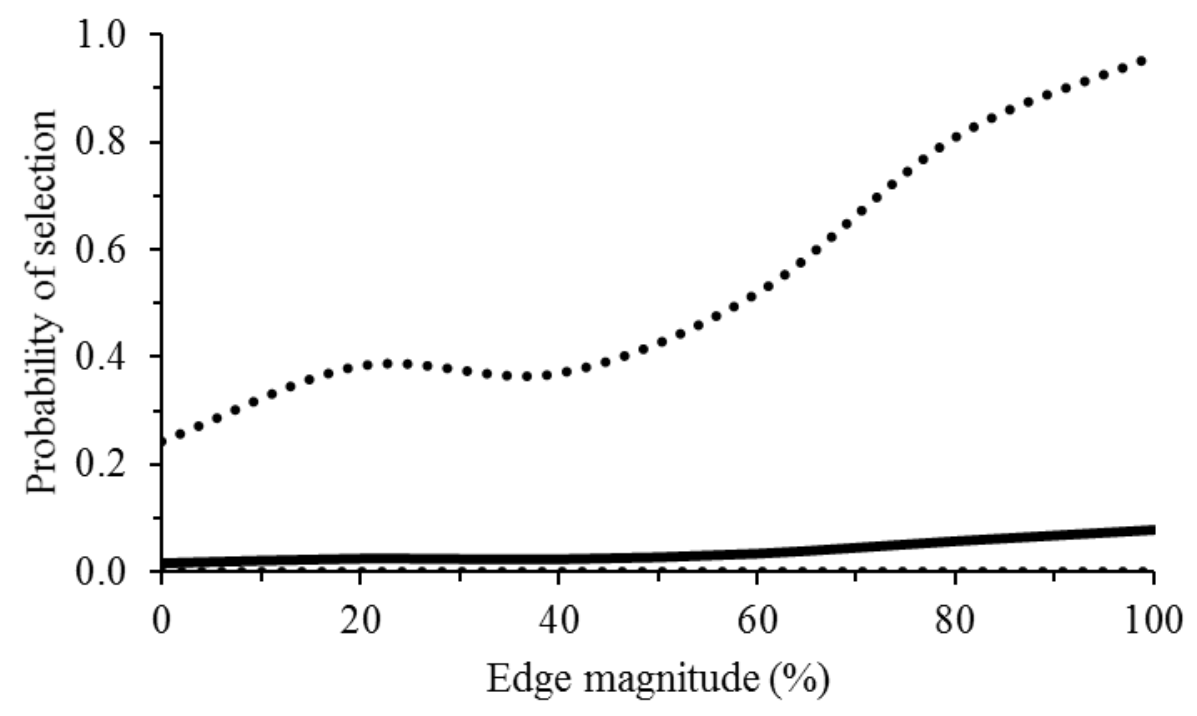

Figure 4. During 2011-2014 in West Virginia, Golden-winged Warblers selected territories with larger edge magnitude compared to the full simulated distribution of possible shrub community configurations. Edge magnitude was the absolute value of the difference in shrub cover on either side of the center point of a transect. We assigned the maximum value of the two transects for each plot. Therefore, a value of $0 \%$ suggests a lack of edge characteristics, while a value of $100 \%$ is equivalent to complete shrub cover on one side of the transect center point and a lack of shrub cover on the opposite site of the transect center point. 


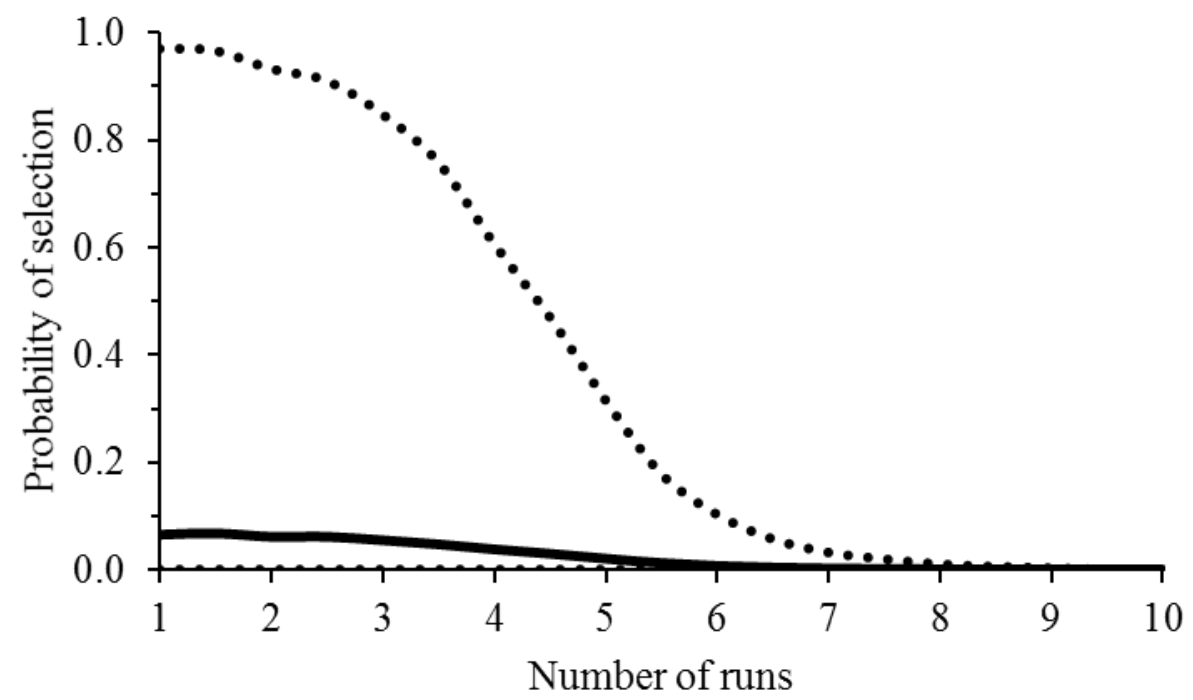

Figure 5. During 2011-2014 in West Virginia, Golden-winged Warblers selected territories with fewer runs compared to the full simulated distribution of possible shrub community configurations. A "run" (range =1-11) is defined as a sequence of consecutive shrub presences or absences along a 22.6-m line-point intercept transect with 11 equally spaced points. A new run occurs whenever occurrence (present or absent) changes. We assigned the mean value of the 2 transects for each plot. 


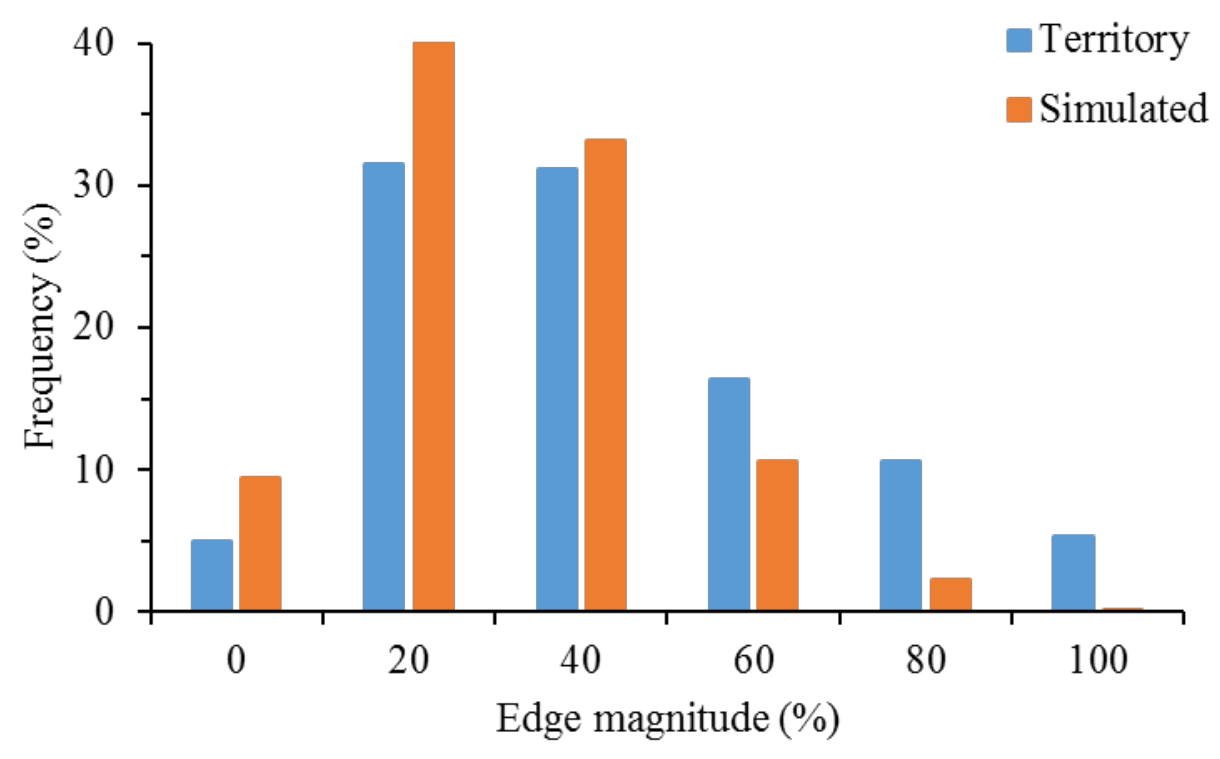

Figure 6. Golden-winged Warbler territories had more pronounced edges than would be expected given a random shrub configuration with an equivalent amount of shrub cover. Edge magnitude was the absolute value of the difference in shrub cover on either side of the center point of a transect. We assigned the maximum value of the two transects for each plot. Therefore, a value of $0 \%$ suggests a lack of edge characteristics, while a value of $100 \%$ is equivalent to complete shrub cover on one side of the transect center point and a lack of shrub cover on the opposite site of the transect center point. 


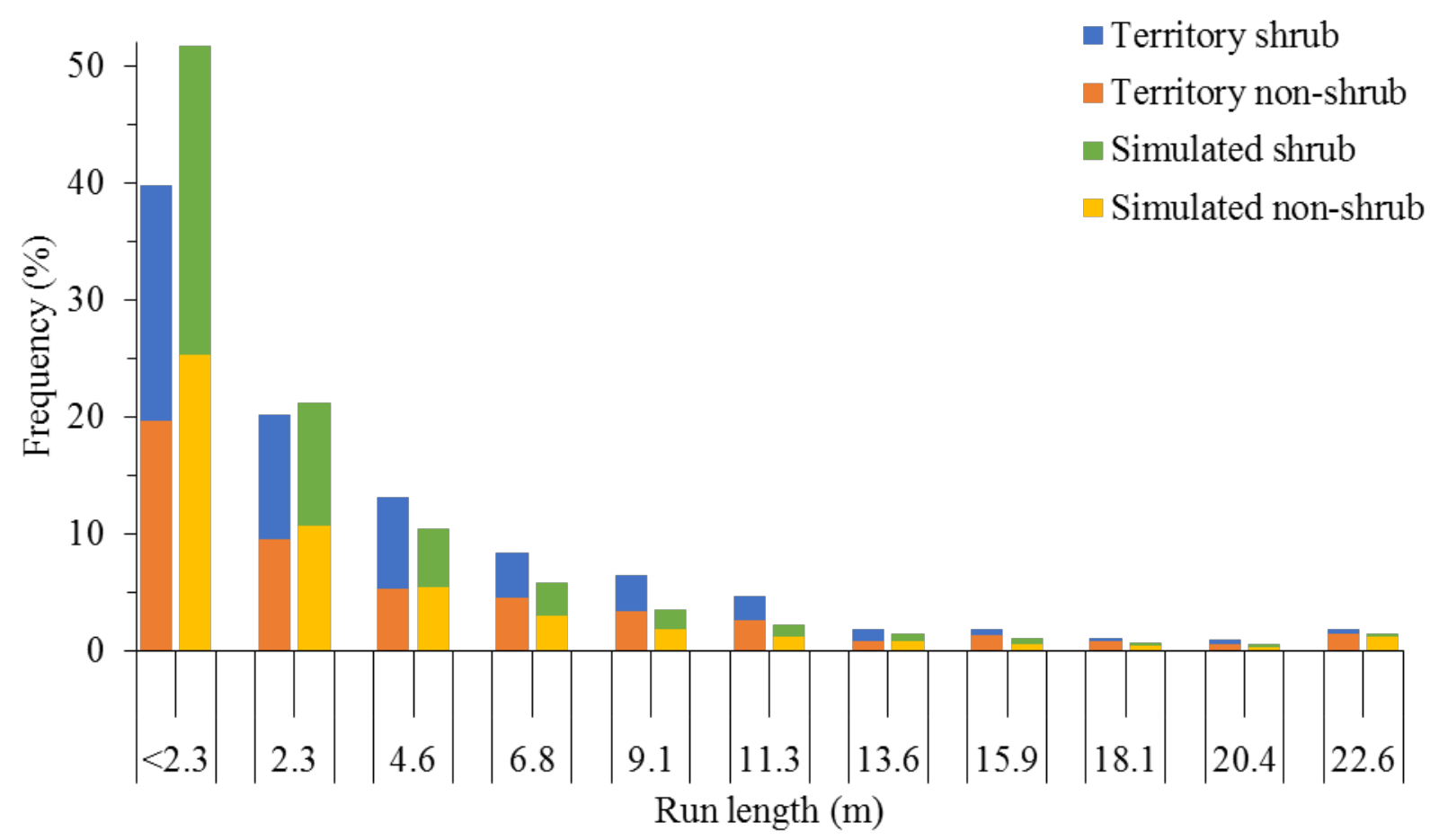

Figure 7. Golden-winged Warblers territories had a more clumped rather than dispersed or uniform shrub configuration than would be expected given a random shrub configuration with an equivalent amount of shrub cover. A "run" (range $=1-11$ ) is defined as a sequence of consecutive shrub presences or absences along a 22.6-m line-point intercept transect with 11 equally spaced points. A new run occurs whenever occurrence (present or absent) changes. We assigned the mean value of the 2 transects for each plot. 


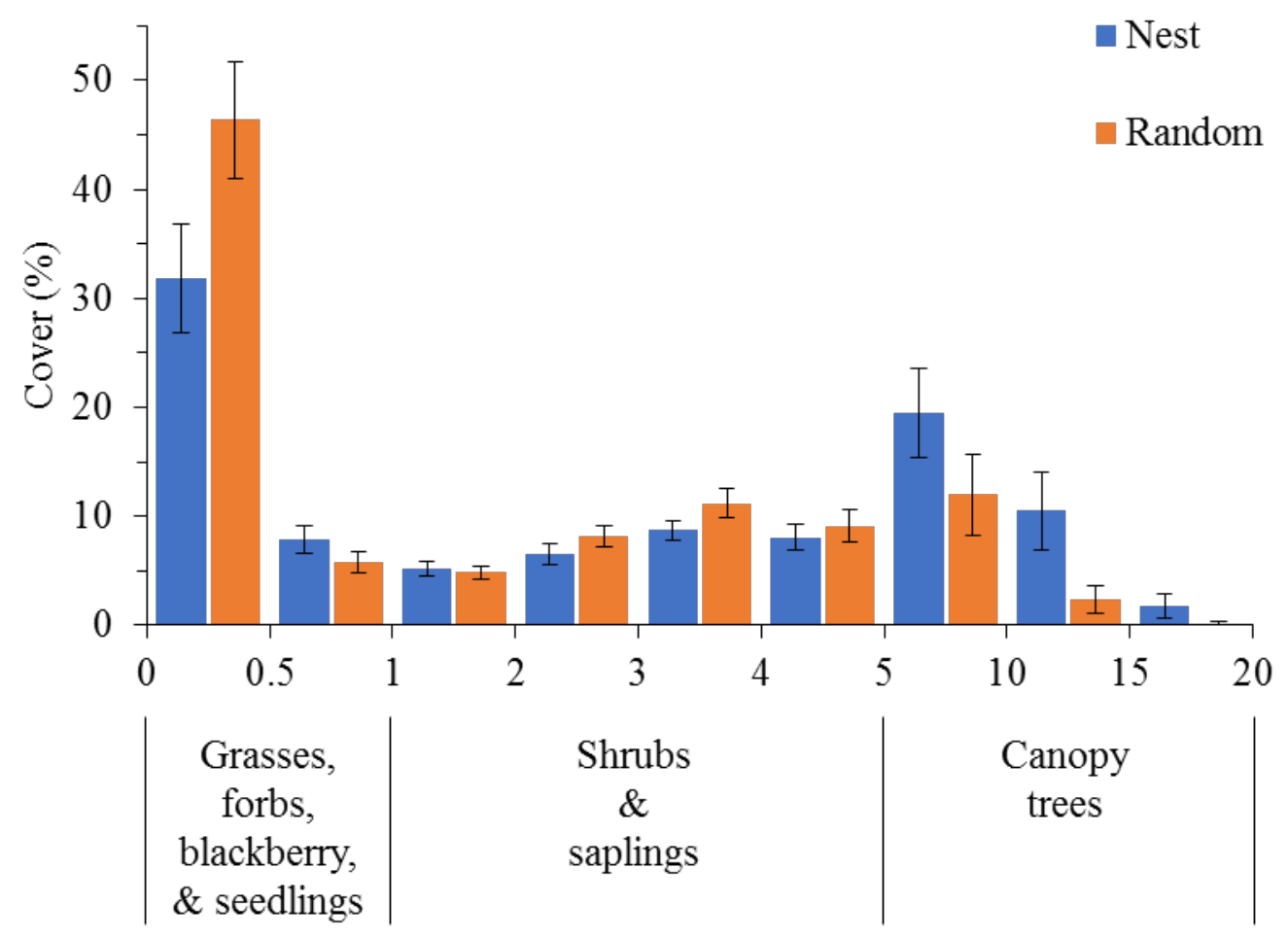

Vegetation Canopy Height (m)

Figure 8. Vegetation canopy height (m) at Golden-winged Warbler nest sites was significantly taller and more variable compared to random plots. Specifically, nests had less short vegetation $(\leq 0.5 \mathrm{~m}$ ), such as grasses, forbs, blackberry (Rubus spp.), and seedlings, in the canopy and more trees $>5 \mathrm{~m}$ tall. 


\section{PART 3. GOLDEN-WINGED WARBLER MANAGEMENT}

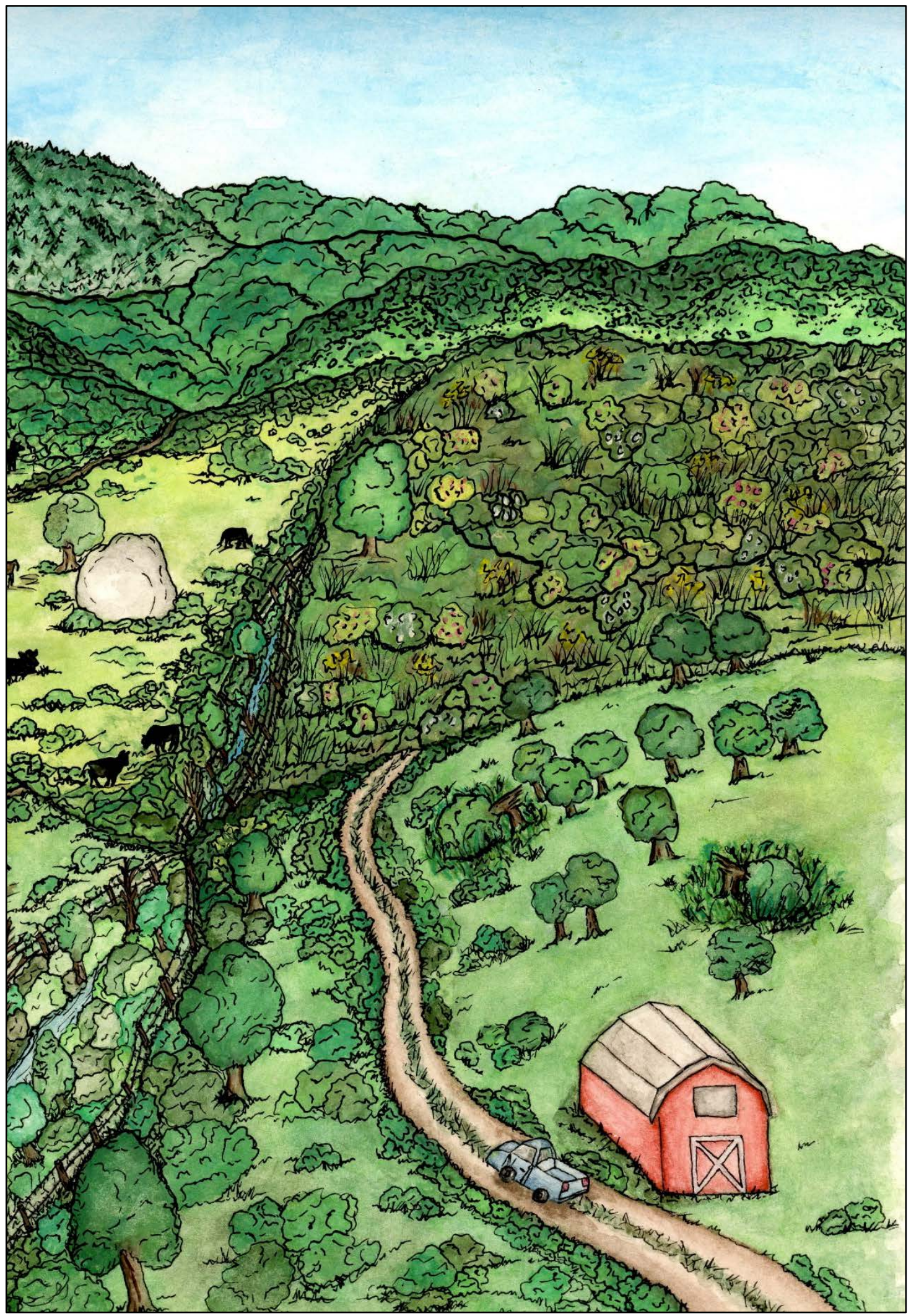




\title{
CHAPTER 5. HOW LONG DO SHRUBLAND NESTING BIRDS PERSIST ON ABANDONED PASTURES?
}

\section{Formatted in the style of Rangeland Ecology and Management.}

\begin{abstract}
The ephemeral nature of early-successional vegetation communities and alterations to ecological disturbance regimes have contributed to widespread population decreases of shrubland-breeding birds in eastern North America. Shrublands on pastures represent a promising source of habitat because of their relative successional stability compared to postharvest young forests and concurrent benefits for livestock and wildlife. During 2008-2014 in the Allegheny Mountains of West Virginia, we conducted 10-min, 100-m radius avian point counts on a 62-year chronosequence of cattle pastures with varying numbers of years since abandonment. Across the chronosequence, we modeled density of Field Sparrows (Spizella pusilla) and Golden-winged Warblers (Vermivora chrysoptera), two bird species that nest in earlier and later stages of shrubland vegetative succession, respectively, as well as overall shrubland-nesting bird species richness. Field Sparrow density peaked on active pastures, Golden-winged Warbler density peaked 16-20 years after pasture abandonment and reached zero 33 years after abandonment, and shrubland-nesting bird species richness did not vary across our chronosequence. We also modeled pasture land cover as a function of years since abandonment. Herbaceous cover peaked on active pastures at 26\% then declined linearly, shrubland cover peaked 18 years since abandonment at $49 \%$, and forest cover increased linearly to a peak of $86 \%$ at 59 years since abandonment. Thus, abandoned pastures in our study area provide breeding habitat for a stable number but changing composition of shrubland-nesting bird species for approximately 60 years, though conservation value likely is highest $0-33$ years after abandonment. The number and abandonment rate of farms in West Virginia and regionally are historically low, suggesting that managing for shrubland-nesting birds on existing or recentlyabandoned pastures is important but alone may not support population persistence. Thus, increased forest management practices may be needed to supplement breeding habitat on pastures, particularly $<2 \mathrm{~km}$ from existing pastures.

Keywords: Field Sparrow; forest; Golden-winged Warbler; grazing; Spizella pusilla; Vermivora chrysoptera
\end{abstract}




\section{INTRODUCTION}

Shrubland and young forest vegetation communities usually are ephemeral, and in turn so is the occurrence of avian species that rely on them. Rapid vegetative succession in conjunction with increasingly suppressed natural and anthropogenic disturbance regimes has resulted in reductions in shrubland and young forest extent and populations of many disturbance-dependent birds in eastern North America (King and Schlossberg 2014). One response from the conservation community has been to prioritize creation of early-successional vegetation communities by promoting and incentivizing best management practices on public and private working lands (e.g., Young Forest Project, www.youngforest.org; Working Lands for Wildlife, U.S. Natural Resources Conservation Service 2012). Among these best management practices, ecologically-driven forest management ultimately must be a primary mechanism to increase the amount of new early-successional vegetation communities in the landscape (DeGraaf and Yamasaki 2003, Swanson et al. 2010). However, creation of young forests can face substantial obstacles because of fluctuating forest-product markets (Prestemon et al. 2015), special considerations for listed forest wildlife species (Guldin et al. 2007), and the relative briefness that post-harvest stands are suitable for some disturbance-dependent birds (Bakermans et al. 2015a, McDermott and Wood 2009, McDermott et al. 2011). Therefore, enhancing existing pastures represents a promising source of shrubland cover because the existing vegetative structure may already be similar to structure preferred by some early-successional obligates (Aldinger and Wood 2014), thus the change in management level required to achieve that preferred structure could be minimal. Furthermore, preferred structure could persist indefinitely with the appropriate grazing system or for multiple decades even if the pasture is abandoned (Stephens and Ward 1992, Latham 2003).

Stocking cattle at levels compatible with development of shrubland cover (1.2-2.4 ha of forage per bull or cow-calf pair, Aldinger and Wood 2014), which occurs commonly on farms in our study area in the Allegheny Mountains of West Virginia (U.S. National Agricultural Statistics Service 2017), is one management tool for enhancing pastures for shrubland-nesting birds (Schieltz and Rubenstein 2016). Pasture abandonment is another often unintentional method to promote shrubland cover. The number of farms in West Virginia decreased by 81\% between the record high of 105,000 in 1935 and the record low of 19,600 in 1978 and has since stabilized (U.S. National Agricultural Statistics Service 2017). This provided a source of 
shrubland cover during the mid- to late-twentieth century, but vegetation on these abandoned farms has now matured beyond the successional stage required by most shrubland-nesting birds (Litvaitis 1993). Conservation programs such as Working Lands for Wildlife (U.S. Natural Resources Conservation Service 2012) and the Conservation Reserve Program (U.S. Farm Service Agency 2017), which can provide financial-assistance and rental payments to private landowners that voluntarily "abandon” environmentally sensitive portions of pasture to improve water quality and wildlife habitat and reduce soil erosion, are potential mechanisms to continue the benefits of abandoned pastures today. Yet, a knowledge gap hindering the conservation of shrubland-nesting birds in West Virginia and throughout the Appalachian Mountains region is how these species respond to vegetative succession associated with pasture abandonment. For example, the best management practices document for Golden-winged Warbler (Vermivora chrysoptera) habitat on abandoned farmlands in the Appalachians vaguely states that breeding habitat may persist for a "period of years” or "less than a decade” on abandoned farms (Goldenwinged Warbler Working Group 2013).

With a reduction or elimination of grazing pressure, pastures tend to return to a preagricultural state if biotic (e.g., native seed sources) and abiotic (e.g., soil properties) thresholds were not crossed during the previous management regime (Cramer et al. 2008). This selfrestoration ability is more likely in highly productive regions, such as the western slopes of the Allegheny Mountains (Strausbaugh and Core 1978), meaning that lightly-grazed pastures in our study area are unlikely to exceed the biotic and abiotic thresholds that would prevent them from returning to a near-pre-agricultural state. Therefore, we sampled a chronosequence of cattle pastures (0-62 years since abandonment) representing a vegetative successional gradient to measure the persistence of shrubland-nesting birds on abandoned pastures. We modeled density of Field Sparrow (Spizella pusilla) and Golden-winged Warbler as focal species representative of early and later stages of shrubland vegetative succession, respectively (Carey et al. 2008, Confer et al. 2011). We also modeled overall shrubland-nesting bird species richness across our chronosequence to assess the response of the overall shrubland-nesting bird community and to provide additional context for our density models. Finally, we examined temporal land cover change across our chronosequence to help explain patterns of shrubland-nesting bird density and richness. 


\section{METHODS}

\section{Focal Species}

To select our two shrubland-nesting bird focal species, we identified species of greatest conservation need from the West Virginia state wildlife action plan that nest in shrublands so that our results would benefit state-level conservation efforts for priority species (West Virginia Division of Natural Resources 2015). This list included species from the "Grasslands and Old Field" and "Early Successional Forest” species groupings so that we would draw two species from different shrubland successional stages. To ensure an adequate number of male detections for modeling detection probability and density, we selected the most abundant "Grassland and Old Field” (hereafter, “sparse shrubland”) and “Early Successional Forest” (hereafter, “dense shrubland”) species.

The Field Sparrow was our most abundant sparse shrubland species ( $\mathrm{n}=577$ male detections). Field Sparrows are partial migrants that occur year-round throughout the continental United States east of the Rocky Mountains (Carey et al. 2008). The species nests on or near the ground in old fields with scattered woody vegetation that provides elevated perches and nest sites (Best 1978). Breeding occurs on active pasture and hayfield (Giuliano and Daves 2002) and continues for a decade or more after management stops (Carey et al. 2008). Although Field Sparrows remain relatively abundant across much of their breeding range, populations have decreased significantly throughout the Appalachian Mountains bird conservation region (19662015 mean annual change: -2.9\% per year, 95\% confidence limits CL: -3.2\%, -2.6\%; Sauer et al. 2017).

The Golden-winged Warbler was our most abundant dense shrubland species ( $\mathrm{n}=161$ male detections). Golden-winged Warblers are Neotropical migratory songbirds that nest on the ground in shrubland and young forest vegetation communities at mid- to high-elevations within heavily-forested landscapes of the Appalachian Mountains and Great Lakes regions of North America (Roth et al. 2012). Breeding habitat consists of a patchy mix of grasses, forbs, shrubs, saplings, and sparse canopy tree cover adjacent to a forest edge, often resulting from agricultural abandonment and timber harvesting (Confer et al. 2011). Significant negative population trends, especially in the Appalachian Mountains bird conservation region (1966-2015 mean annual change: -8.6\% per year, 95\% CL: -9.8\%, -7.3\%; Sauer et al. 2017), have resulted in its classification as one of the highest priority bird species for conservation in North America 
(Rosenberg et al. 2016) and a species undergoing status review for Endangered Species Act listing in the United States.

\section{Study Area}

During 2008-2014, we conducted avian point counts on a chronosequence of public(Monongahela National Forest; $n=44)$ and private-land $(n=24)$ cattle pastures with varying lengths of time since abandonment (range 0-62 years, Fig. 1). This research began as part of a larger study on Golden-winged Warblers, so our pastures were within the contemporary breeding range of the Golden-winged Warbler in Monroe, Pendleton, Pocahontas, Randolph, and Tucker counties, West Virginia (Roth et al. 2012). We sampled any pastures in our study area that met the following criteria: (1) adequate elevation (>500 m) and forest cover (>60\% within $2.5 \mathrm{~km})$ to potentially support Golden-winged Warbler populations (Crawford et al. 2016), (2) current or pre-abandonment cattle stocking levels favorable for establishment of woody cover needed by nesting Golden-winged Warblers (1.2-2.4 ha of forage per bull or cow-calf pair; Aldinger and Wood 2014), and (3) landowners that would allow access. We defined a pasture $(n=68)$ as a closed, contiguous fenced area grazed by cattle. We digitized pasture fence boundaries using a combination of global positioning system units in the field, current and historic aerial photographs, and parcel maps to determine pasture size (mean \pm SE: $61 \pm 14$ ha, range 3-879 ha).

All pastures were bordered at least partly by forest, which we defined as near $100 \%$ closed canopy of trees $>10 \mathrm{~cm}$ diameter at breast height (dbh), but generally dominated by sawtimber trees $>25 \mathrm{~cm}$ dbh. Pastures were embedded in a predominantly forested landscape (mean \pm SE: $84 \pm 1 \%$ forest cover within $2.5 \mathrm{~km}$, range: 61-95\%) with elevations of 574-1,343 m. Within fenced boundaries, land cover consisted of a variable mosaic of herbaceous (range: 094\%), shrubland (0-95\%), and forest (4-96\%) cover (Aldinger et al. 2017) depending on the number of years since abandonment. Dominant plant species included sedges (Carex L.), sweet vernal grass (Anthoxanthum odoratum L.), goldenrod (Solidago L.), virgin’s bower (Clematis virginiana L.), hawthorn (Crataegus L.), crabapple (Malus Mill.), white ash (Fraxinus americana L.), and black locust (Robinia pseudoacacia L.).

\section{Pasture Management Regime}

We used a combination of written records (leases and USDA Forest Service records), landowner interviews, and historic aerial photographs to determine if the current or historic 
stocking rate was within 1.2-2.4 ha of forage per bull or cow-calf pair and to estimate the time since grazing abandonment if the pasture was no longer active. We defined a pasture-year as the period from 1 October of the prior calendar year to 30 September of the current calendar year in which we conducted an avian point count to correspond with the grazing season on the Monongahela National Forest (15 May - 1 October). All active pasture-years $(\mathrm{n}=156)$ had grazing for at least 4.5 months during the growing season. Periodic mowing and liming occurred on active pastures. Active pastures were not strictly production-oriented, meaning that “wildlifefriendly" characteristics including patches of unpalatable forage, shrubs, and trees were present and persistent. All abandoned pasture-years $(\mathrm{n}=81)$ had $(1)$ no grazing during the pasture-year and (2) no other forms of management (e.g., mowing) since abandonment. Two pastures transitioned from active to abandoned during our study and one pasture from abandoned to active.

\section{Avian Point Counts}

We randomly distributed point count locations $\geq 250 \mathrm{~m}$ apart across each pasture to decrease risk of double-counting individual birds (Ralph et al. 1995). We eliminated point count locations with 100\% herbaceous or closed-canopy forest cover within $100 \mathrm{~m}$ because such locations would not be used by nesting Golden-winged Warblers and other shrubland birds (Confer et al. 2011). This stratified random sample limited the number of point count locations to 1-9 per pasture (mean \pm SE: $2.2 \pm 0.2$ point count locations). In total, we conducted 539 point counts at 151 point count locations (mean \pm SE: $77 \pm 17$ point counts per year, range: 16-137 point counts per year) distributed across 68 pastures (mean \pm SE: $34 \pm 8$ pastures per year, range: 8-61 pastures per year).

Annually before point counts began (April 25-May 19), KRA trained all observers ( $\mathrm{n}=8$ total observers, 1-4 observers per year) together in bird identification and distance estimation. Each observer had at least one full season of experience conducting point counts for birds in eastern North America prior to this study. We practiced bird identification with tests of actual and recorded bird vocalizations and distance estimation by estimating known distances. During the 2-3 d before point counts began, we concurrently, but independently conducted 10-min practice point counts as a group at the same point count locations and compared our results to help standardize results among observers. In a related study, we did not find evidence that male 
Golden-winged Warbler detection probability varied among these observers, suggesting that training was sufficient to standardize results among observers (Aldinger et al. 2017).

We conducted 10-min, single-annual-visit, 100-m fixed-radius point counts (Dettmers et al. 1999) from 6 mins before to 294 mins after sunrise (mean \pm SE: $124 \pm 3$ min since sunrise) during 20 May-21 June (mean \pm SE: 29 May \pm 0.3 d). We conducted point counts on days with calm and clear weather to reduce interference with visual and aural detection of birds. We recorded the detection type (call, flyover, non-vocal sound, song, or visual), distance category ( $\leq 25 \mathrm{~m},>25-50 \mathrm{~m},>50-100 \mathrm{~m}$, or $>100 \mathrm{~m}$ ), sex (male, female, unknown, or juvenile), and time interval $(0-2,>2-3,>3-4,>4-5,>5-6,>6-7,>7-10 \mathrm{~min})$ for each bird detection.

\section{Statistical Analysis}

We used program R (R Development Core Team 2017) for all analyses. We considered results statistically significant at $a \leq 0.05$.

\section{Shrubland-nesting bird density}

We modeled Golden-winged Warbler and Field Sparrow density, each separately, as a function of pasture-years since pasture abandonment (hereafter, “years since abandonment”) using a Poisson lognormal mixed effect model fitted with Laplace approximation with function glmer within package Ime4 (Bates et al. 2017). For each species, we included non-flyover counts of adult males within a 100 -m radius during our 10 -min point counts. We assigned a value of zero years since abandonment for active pasture-years and increased years since abandonment sequentially each year following pasture abandonment. We included a single linear fixed effect term for years since abandonment in the Field Sparrow density model. We expected Field Sparrow density to peak in active pastures when herbaceous cover would be highest but with adequate scattered woody vegetation for elevated perches (Carey et al. 2008). We included linear and quadratic fixed effect terms for years since abandonment in the Golden-winged Warbler density model because we hypothesized that Golden-winged Warbler density would peak approximately 10 years after pasture abandonment (Golden-winged Warbler Working Group 2013) when pastures would be dominated by the species’ preferred dense shrubland cover (Confer et al. 2011). We included a random intercept for pasture ID to help account for nonindependence among and repeated measures of point count locations within each pasture (Bates et al. 2015). We also included a random slope for pasture size because plant successional trajectory, and in turn bird density, may vary depending on patch size (Cook et al. 2005). 
Because of the size and shape of some pastures, the $100-\mathrm{m}$ point count radius sometimes extended beyond the fenced pasture boundary. Therefore, we included prior weights in our model (Bates et al. 2017) representing the proportion of each $100-\mathrm{m}$ point count radius that was within the fenced pasture boundary (mean \pm SE: $0.90 \pm 0.01$, range: $0.40-1.00$ ). We used the bootMer function within package Ime4 to derive bootstrapped 95\% confidence intervals (CI) around predicted values from our model using 1,000 bootstrap replications (Bates et al. 2017).

To account for imperfect detection of Golden-winged Warblers and Field Sparrows during point counts, we combined distance-sampling (Buckland et al. 2001) and time-removal (Farnsworth et al. 2002) methods to model the two components of detection probability: availability (a), the probability that an individual bird presents a cue available for detection, and perceptibility $(q)$, the probability that an observer detects an individual bird, given that the bird is available for detection. We used package detect (Sólymos et al. 2014) to formulate constant (i.e., intercept-only) conditional multinomial maximum likelihood models of $a$ (i.e., time-removal model) and $q$ (i.e., distance-sampling model). As inputs, $a$ and $q$ models use matrices of counts of males corresponding to time and distance intervals that we recorded during point counts. Due to concern about overextending the utility of our model-based corrections for detection bias (Hutto 2016), we did not model $a$ or $q$ as functions of covariates because of the relatively small number of point counts $(n=539)$ and detections of male Golden-winged Warblers $(n=161)$. We used the product of modeled estimates of $a$ and $p$, as well as the point count area sampled ( $\pi \times$ point count radius ${ }^{2}$ ), as log-transformed offsets in our Poisson regression model to correct for detection bias and convert raw counts to a density output (Sólymos et al. 2013).

\section{Shrubland-nesting bird richness}

We modeled species richness of shrubland-nesting birds as a function of years since abandonment using a Poisson lognormal mixed effect model fitted with Laplace approximation with function glmer within package Ime4 (Bates et al. 2017). We used non-flyover detections of adult male or female shrubland-nesting bird species within a 100-m radius during a 10-min point count to indicate species presence in our shrubland species richness model. We defined a shrubland-nesting bird species as one classified as "successional or scrub breeding” from the North American Breeding Bird Survey (Table 1, Sauer et al. 2017). We included linear and quadratic fixed effect terms for years since abandonment because the nesting habitat preferred by shrubland-nesting birds was expected to be most abundant at an intermediate number of years 
along our chronosequence, after herbaceous cover had succeeded to shrubland and before shrubland had succeeded to forest. Equivalent to our density models, the shrubland-nesting bird richness model included a random intercept for pasture ID, a random slope for pasture size, and prior weights representing the proportion of each 100 -m point count radius that was within the fenced pasture boundary.

\section{Land cover}

To provide context for our shrubland-nesting bird density and richness models relative to vegetative succession, we separately modeled the proportions of three land cover classes within pastures as a function of years since abandonment. We used herbaceous (dominated by grasses and forbs with $<30 \%$ woody cover), shrubland ( $\geq 30 \%$ shrub cover generally dominated by $\leq 10$ cm dbh stems with few scattered canopy trees and herbaceous understory), and forest (nearly $100 \%$ closed canopy consisting of trees $>10 \mathrm{~cm} \mathrm{dbh}$ ) land cover classes manually-digitized from 2011 aerial photographs (Aldinger et al. 2017). Proportions of shrubland, herbaceous, and forest cover do not necessarily sum to $100 \%$ because of the potential presence of barren, young forest, road, structure, and water land cover classes (Aldinger et al. 2017). We calculated proportions of shrubland, herbaceous, and forest cover within the fenced boundary of each pasture in ArcGIS 10.3 (ESRI 2011). Because we had land cover data for 2011 only, individual pastures ( $\mathrm{n}=68$ ) had a single value for years since abandonment corresponding to the number of years since abandonment for that pasture in 2011 (range 0-59 years).

We used function glmmadmb within package glmmADMB (Skaug et al. 2016) to formulate three separate beta regression models each with probit link, fixed effect for years since abandonment, and a random slope for pasture size. The herbaceous cover model and the forest cover model each included a linear fixed effect for years since abandonment because these land cover classes represent the earliest and latest vegetative successional classes in our study area, respectively. The shrubland cover model included linear and quadratic fixed effects for years since abandonment because shrubland cover is the intermediate vegetative successional class between herbaceous and forest cover. Beta regression requires that values for proportion of land

cover be $>0$ and $<1$. Because herbaceous (range: 0-94\%) and shrubland (0-95\%) cover had zero values, we transformed the data using $(y \times(n-1)+0.5) / n$, where $y$ is the proportion of land cover and $n$ is the sample size of pastures (Smithson and Verkuilen 2006). We used the 
predict.glmmadmb function within package glmmADMB to derive 95\% CIs around the predicted values from land cover models.

\section{RESULTS}

\section{Shrubland-nesting Bird Density \\ Detection probability}

We detected male Golden-winged Warblers $(\mathrm{n}=161$ detections) and Field Sparrows $(\mathrm{n}=$ $577)$ within $100 \mathrm{~m}$ at $36 \%(\mathrm{n}=54)$ and $87 \%(\mathrm{n}=131)$ of point count locations and at $44 \%(\mathrm{n}=$ 30) and 91\% $(n=62)$ of pastures across 2008-2014, respectively. The intercept terms in our constant (i.e., intercept-only) models of $a$ and $q$ were statistically significant (Table 2), suggesting imperfect detection of both species. Overall detection probability, or the product of estimates for $a$ and $q$, was 31\% for Golden-winged Warbler $(a \times q=0.99 \times 0.31)$ and 35\% for Field Sparrow $(a \times q=0.98 \times 0.35)$ within 100 -m during a 10 -min point count.

\section{Golden-winged Warbler density}

Male Golden-winged Warbler density was statistically significantly associated with years since abandonment (Table 3, Fig. 2). Predicted mean density peaked at 20 years since abandonment (mean $=0.5$ males per ha, 95\% CI $=0.2-1.0$ ), which was 4 times higher than density on active pastures (mean $=0.1$ males per ha, $95 \% \mathrm{CI}=0.1-0.2$ ). More conservatively, the lower bound of our $95 \%$ CI of density peaked at 16 years since abandonment $(0.2$ males per ha). Our model intercept term was significant (Table 3) and we detected Golden-winged Warblers on 39\% of active pastures across 2008-2014, suggesting that active pastures with stocking levels of 1.2-2.4 ha of forage per bull or cow-calf pair can support territorial male Golden-winged Warblers. The lower bound of our 95\% CI reached 0.0 (rounded) at 33 years, representing a conservative estimate of the longevity of Golden-winged Warbler breeding habitat on abandoned pastures.

\section{Field Sparrow density}

Male Field Sparrow density was negatively associated with years since abandonment (Table 3, Fig. 2). Predicted mean density peaked in active pastures (mean $=1.1$ males per ha, 95\% CI = 0.9-1.2). The CI around predicted mean density did not reach zero within our chronosequence, suggesting the species may be relatively flexible in its use of breeding habitat across a broad range of shrubland succession. 


\section{Shrubland-nesting Bird Richness}

We detected 22 shrubland-nesting bird species, which individually occurred on 1.195.0\% of pastures during 2008-2014 (Table 1). Linear and quadratic terms for years since abandonment were not significant in our shrubland-nesting bird richness model, although the intercept was significant with a predicted mean richness of 6.0 species (95\% CI $=5.6-6.4)$ on active pastures (Table 3). This suggests that shrubland species richness was relatively constant and significantly greater than zero across our chrono-sequence of pastures.

\section{Land Cover}

Predicted mean herbaceous cover peaked on active pastures at $26 \%$ cover ( $95 \%$ CI = $21-$ $32 \%$ ) then declined linearly, shrubland cover peaked 18 years since abandonment at 49\% (95\% $\mathrm{CI}=25-73 \%)$, and forest cover increased linearly to a peak of 86\% (95\% CI $=68-95 \%)$ at 59 years since abandonment (Table 4, Fig. 3). Graphs of herbaceous and shrubland cover (Fig. 3) mirror those of male Field Sparrow and Golden-winged Warbler density (Fig. 2), respectively. At peak predicted mean density of Field Sparrows on active pastures, predicted mean herbaceous cover was $26 \%$ (95\% CI $=21-32 \%)$, shrubland cover was 37\% (95\% CI = 30-43\%), and forest cover was 31\% (27-37\%). At peak predicted mean density of Golden-winged Warblers 16-20 years since abandonment, predicted mean herbaceous cover was 16-17\%, shrubland cover was 48-49\%, and forest cover was 48-52\%. After 33 years, which was our conservative estimate of the longevity of Golden-winged Warbler breeding habitat on abandoned pastures, herbaceous cover was $10 \%(95 \% \mathrm{CI}=5-21 \%)$, shrubland cover was $40 \%(95 \% \mathrm{CI}=6-86 \%)$, and forest cover was 65\% (95\% CI = 51-77\%). The 95\% CI around predicted mean shrubland cover broadened to include nearly the entire range of possible values by 40 years since abandonment

(Fig. 3). This broad CI likely reflects the small sample size of long-abandoned pastures as well as the variation in temporal persistence of long-lived shrub cover compared to short-lived herbaceous cover.

\section{DISCUSSION}

\section{Golden-winged Warbler Density}

Temporally-explicit data are a pivotal component of an effective multi-species management plan, especially for shrubland-nesting birds that may colonize a patch after a multiple-year lag following management and then may persist for relatively few years before 
vegetative conditions become unsuitable (Bakermans et al. 2015a). At the scale of a single pasture, temporal data inform managers of appropriate rest and re-entry intervals given their management objectives. Our data suggest that mean Golden-winged Warbler density peaked on abandoned pastures after a rest period of 16-20 years and that nesting habitat for the species persisted for 33 years, though the species also used active pastures at lower densities. This result greatly extends the estimated persistence of Golden-winged Warbler breeding habitat from the best management practices for abandoned pastures in the Appalachians, which indicated that breeding habitat may persist for less than a decade (Golden-winged Warbler Working Group 2013). At broader scales, temporal data can help planners achieve desired proportions of different seral stages in the landscape over time. By extension, information on the longevity and abundance of shrublands could be used to project regional Golden-winged Warbler population sizes in the context of attaining conservation objectives (Roth et al. 2012) or assessing risk of reaching minimum population thresholds (Boyce 1992).

To this last point, the number of farms in West Virginia reached an all-time high of 105,000 in 1935, dropped to an all-time low of 19,600 in 1978, and has remained near 1978 levels ever since (20,600 in 2016, U.S. National Agricultural Statistics Service 2017). Farm acreage similarly decreased then plateaued (Widmann et al. 2012). Given our results and assuming golden-winged warbler population trends are associated with availability of breeding habitat, we would expect an increased rate of population decline around 1994-1998, corresponding with a 16-20-year delay following the 1978 all-time low and subsequent plateau in farm numbers. However, Golden-winged Warbler populations in West Virginia and throughout the Appalachian Mountains region have declined consistently since 1966 (see Sauer et al. 2017 and previous archived versions for comparison of long-term and most-recent 10-year trends). The absence of an apparent shift in population trend may be because (1) factors other than availability of breeding habitat are more limiting (King et al. 2016, Vallender and Bull 2016), (2) contemporary North American Breeding Bird Survey trends for the Appalachian Mountains region are unreliable (Rohrbaugh et al. 2016), or (3) both. Light-level geolocators able to record Golden-winged Warbler location data year-round may soon be able to explain these population trends by helping to pinpoint geographically- and temporally-explicit limiting factors (Kramer et al. 2017). Nonetheless, the species’ future in West Virginia appears bleak without at least maintaining sources of breeding habitat moving forward (Rohrbaugh et al. 2016). 
Creating this new breeding habitat will require conservation on public (17\% of land area) and especially private land (83\% of land area, U.S. Geological Survey 2016) within the Goldenwinged Warbler's breeding range in West Virginia (Roth et al. 2016). The Monongahela National Forest operates a range allotment program totaling approximately 1,097 ha (U.S. Forest Service 2011), many of which are at elevations and within forested landscapes suitable for Golden-winged Warblers (Aldinger and Wood 2014). However, the biggest opportunity to apply findings of our study is on the 224,274 ha of privately-owned pasture (U.S. National Agricultural Statistics Service 2017) within the U.S. Natural Resources Conservation Service’s (2012) Working Lands for Wildlife focal area in West Virginia and on private pastures in other central Appalachian states. Small cattle farms, and local economies to which they belong, likely would struggle with retiring any substantial amount of pasture for 16-20 years given promising economic opportunity (Evans et al. 2011). However, Golden-winged Warblers do occur on active pastures with 1.2-2.4 ha of forage per bull or cow-calf pair and our model predicted an increase in mean density each year following abandonment up 20 years. Golden-winged Warbler nest survival on these pastures was comparable to nest survival in other vegetation communities across the species' breeding range (Aldinger et al. 2015) and the presence of livestock grazing was not associated with nest survival (Aldinger and Wood 2014). Thus, with technical and financial assistance through initiatives such as Working Lands for Wildlife (U.S. Natural Resources Conservation Service 2012), some managers may be able to reduce stocking rates or rest portions of pasture for a longer number of years to enhance shrublands for Golden-winged Warblers.

To complement enhancement of existing pastures, promoting forest management practices that benefit Golden-winged Warblers (Bakermans et al. 2011) represents a primary option for increasing the amount of early successional habitat in West Virginia and regionally because conversion rates from agriculture to forest are greater than conversion rates from forest to agriculture (Morin et al. 2016). Golden-winged Warblers appear to prefer shrub-dominated pastures over young forests created by forest management in our study area (Aldinger et al. 2017), but the species’ use of young forests in the Appalachian Mountains region is welldocumented (Klaus and Buehler 2001, Patton et al. 2010, Bakermans et al. 2015a). Therefore, planning a series of forest management practices $<2 \mathrm{~km}$ from pastures occupied by Goldenwinged Warblers would create a network of relatively stable shrub-dominated pastures 
(longevity without re-entry $=16-33$ years) and relatively ephemeral sapling-dominated young forests (longevity without re-entry $=12$ years, Bakermans et al. 2015a).

Our density model represents a general "rule-of-thumb” for land managers wanting to incorporate Golden-winged Warbler nesting habitat as an objective in a pasture management plan. The broad CI around the predicted mean density suggests that considering pasture-specific biotic and abiotic factors associated with the trajectory of plant succession, such as plant species composition (Davis et al. 2005) and soil biological (Kardol et al. 2006), chemical (McLauchlan 2006), and physical characteristics (Piché and Kelting 2015), could substantially improve a pasture management plan for Golden-winged Warblers. For example, in a study of old fields in Minnesota, oak (Quercus L.) seedling survival decreased by 50\% when grown among smooth brome (Bromus inermis Leyss.), Kentucky bluegrass (Poa pratensis L.), and timothy grass (Phleum pratense L.) compared to native grasses (Davis et al. 2005). Kentucky bluegrass, timothy grass, or both species were in the top-three most-abundant grass species by cover on $19 \%$ of vegetation survey plots $(n=1631)$ from pastures in our study area $(\mathrm{K}$. Aldinger, unpublished results). In cases where highly-competitive non-native invasive species are a concern, continued grazing that supports low densities of Golden-winged Warblers may sometimes be preferable to periods of long-term rest because the latter could compromise wildlife and livestock management objectives through undesirable shifts in plant species composition (Davies et al. 2014). Even relatively low grazing pressure can significantly affect pasture plant communities and soil (Teague et al. 2011). Therefore, routine forage and soil tests combined with adaptive management may incrementally improve on the ability to manage for Golden-winged Warblers through low-intensity grazing and long-term pasture rest.

\section{Field Sparrow Density}

Field Sparrow density peaked on active pastures and remained higher than peak densities of Golden-winged Warblers across nearly our entire range of values for years since abandonment. In old fields in Pennsylvania, Field Sparrow abundance peaked 10 years after human use ceased and breeding continued for up to 30 years (Carey et al. 2008). This 10-year discrepancy between peaks may be explained by differences between the two studies in the vegetative successional state of sites at abandonment. Sites in Carey et al. (2008) were used for hay and tomato production prior to abandonment, whereas our pastures were used for low intensity cattle grazing. Thus, at the time of abandonment our pastures likely contained more of 
the preferred scattered woody vegetation needed for perches and nest sites (Best 1978). At the other end of our chronosequence, we suspect that the Field Sparrow's extended use of abandoned pastures for approximately 45 years after abandonment may be attributable to arrested succession due to the influence of grazing on the plant community and soil characteristics (Teague et al. 2011) and the similarity of some of our pastures to enigmatic "grass balds" or "sods" in the region (Core 1949). Use of long-abandoned pastures is not typical of all priority species that use herbaceous-dominated or sparse shrublands. For example, the next most abundant "Grasslands and Old Field” species from the West Virginia state wildlife action plan (West Virginia Division of Natural Resources 2015) was Eastern Meadowlark (Sturna magna). It had only 20 total detections and all occurred on 9 actively grazed pastures. Therefore, it is important to interpret our observed Field Sparrow density pattern considering individual life history characteristics for other bird species that nest in sparse shrublands. Nonetheless, mid- to high-elevation pastures (>500 m) in the central Appalachian Mountains represent a unique and long-term source of breeding habitat for birds that nest in sparse shrublands because of the potential for arrested succession.

\section{Shrubland-nesting Bird Species Richness}

Sixty-two percent of shrubland-nesting bird species (16 out of 26) occurring in the Appalachian Mountains bird conservation region have significantly decreasing populations (Table 1, Sauer et al. 2017). Many of these populations are thought to be decreasing because of a lack of quality breeding habitat (King and Schlossberg 2014). Twenty-three percent of these species (6 out of 26) occurred on our pastures at any given time during our chronosequence and 85\% (22 out of 26) occurred at some point during our chronosequence. Further, mean annual occurrence for shrubland-nesting bird species with decreasing population trends (mean \pm standard error $=47.4 \pm 9.6 \%$ ) was greater (Welch's one-sided two-sample t-test, $t=1.8, d f=$ $19.4, p=0.04$ ) than that of species with stable or increasing population trends (mean \pm standard error $=21.5 \pm 10.4 \%$ ). This illustrates the importance of active and abandoned pastures as a source of breeding habitat for imperiled shrubland-nesting birds in our study area.

Pastures in our study area, from active through those abandoned for 62 years, provided nesting habitat for a stable number of shrubland-nesting bird species. A lightly-grazed active pasture (1.2 - 2.4 ha of forage per bull or cow-calf pair) might then be considered to have similar conservation value for shrubland-nesting birds as an abandoned pasture. However, individual 
bird species have unique life-histories and reach peak abundance at different numbers of years since abandonment, meaning that there must be temporal species turnover of the shrublandnesting bird community to maintain stable species richness. Furthermore, while richness of shrubland-nesting bird species was stable over time, the extent of shrubland cover and, by extension, the total abundance of shrubland-nesting birds on a pasture varied. Thus, the conservation value of these pastures varies temporally given the conservation priority and abundance of individual shrubland-nesting bird species present at any given time. Future studies of breeding productivity on these pastures may clarify their conservation value for imperiled shrubland-nesting birds.

Our finding that shrubland-nesting bird richness was constant across our chronosequences requires careful consideration because of the underlying composition of bird species and land cover on our pastures. Bird species richness may remain constant despite significant changes to habitat over time because of species turnover (Parody et al. 2001). That seemed to be the case in our study as well, given that Field Sparrows were most abundant on active pastures, Golden-winged Warblers were most abundant 16-20 years after abandonment, and generalist species like Chestnut-sided Warbler (Setophaga pensylvanica), Eastern Towhee (Pipilo erythrophthalmus), and Indigo Bunting (Passerina cyanea) were ubiquitous, occurring on most pastures (Table 1). As such, conservation value may vary temporally depending on the species of interest. For example, Golden-winged Warblers are one of the most imperiled bird

species in the eastern United States (Rosenberg et al. 2016), arguably making 16-20 years since abandonment the most important time for conservation of shrubland-nesting birds on these pastures. This period of time was also when shrubland extent peaked, meaning that the overall abundance of shrubland-nesting birds would presumably be higher than other times despite having equal species richness. Therefore, in scenarios of recurring management for the Goldenwinged Warber and shrubland-nesting birds requiring similar habitat structure, the greatest conservation value may be realized with a maximum re-entry interval for management of 33 years (e.g., the year when Golden-winged Warbler persistence ends).

\section{Land Cover}

Pasture land cover composition changed over time as expected, with herbaceous cover decreasing, shrubland cover peaking at an intermediate time since abandonment, and forest cover increasing. A caveat of these results is that land cover composition varied among pastures at the 
time of abandonment. Still, if we assume that the variation in land cover composition at the time of abandonment is random as it relates to years since abandonment, then our sample nonetheless represents an approximation of vegetative succession on pastures in our study area in West Virginia. We can think of no plausible mechanism that would cause pastures in a certain year to be abandoned in a starkly different compositional state than pastures in another year. Furthermore, trends in land cover change not only matched our hypotheses, but also aligned with results of Field Sparrow and Golden-winged Warbler density modeling. An increased sample size of abandoned pastures or long-term monitoring of the same pastures over time would allow for stronger inference from our land cover models.

In heavily forested landscapes such as around our pastures (mean $\pm \mathrm{SE}: 84 \pm 1 \%$ forest cover within $2.5 \mathrm{~km}$, range: $61-95 \%$ ), our results suggest maintaining $>40 \%$ of a pasture in shrubland land cover and 10-17\% in herbaceous land cover if managing for Golden-winged Warblers. After 33 years, proportions of shrubland (although note broad CI) and herbaceous land cover dropped below this threshold (Fig. 3) and Golden-winged Warbler density reached zero (Fig. 2). Equally as important as coarsely-defined land cover composition, however, are fine scale vegetation characteristics, particularly within shrubland cover itself. Forty percent of a pasture in shrubland cover may seem to be an adequate amount of breeding habitat for Goldenwinged Warblers, but after 33 years without disturbance much of the shrubland cover has reached a closed-canopy state and the herbaceous understory is rare or non-existent (Fig. 1). Golden-winged Warblers generally nest along micro-edges between woody and herbaceous cover (Aldinger and Wood 2014), so interspersion of herbaceous and shrubland cover is important to ensure the species' persistence. Therefore, occasional re-entry into a pasture after abandonment to thin dense stands of shrubs may extend use by high densities of Golden-winged Warblers. Re-initiating grazing after multiple years of abandonment to set back vegetative succession without first clearing some pasture back to herbaceous cover may not benefit Goldenwinged Warblers because cattle tend to browse and trample smaller shrubs, favoring the establishment of a uniform strata of larger shrubs (K. R. Aldinger, personal observation). The resulting shrublands would lack the smaller shrubs (mean \pm SE: $159 \pm 12 \mathrm{~cm}$ tall) that Goldenwinged Warblers favor at nest sites (Aldinger and Wood 2014).

\section{Implications}


Our study is the first to measure persistence of Golden-winged Warbler nesting habitat on pastures, in contrast to multiple studies mentioning persistence of habitat in post-harvest forest stands (Huffman 1997, Klaus and Buehler 2001, Roth and Lutz 2004, Martin et al. 2007, Bakermans et al. 2015a). Furthermore, the results provide information about the level of variation in Golden-winged Warbler density, Field Sparrow density, shrubland-nesting bird species richness, and reforestation on pastures in West Virginia. Future studies of vegetative succession and avian response on pastures in the central Appalachians could be improved by sampling multiple replicates of pastures, each monitored from active grazing through decades of abandonment. Such studies often are not feasible because of the amount of time needed to observe species turnover. Based on our results, that amount of time may be 33 years for a single species like the Golden-winged Warbler or 60 years for the community of shrubland-nesting birds. However, we consider our results to be a somewhat liberal representation of species’ persistence time on abandoned pastures because pastures that persist in an early-successional state longer could be more easily discovered than pastures that succeed more rapidly. A more realistic improvement may be to invest additional time into increasing the sample size of longabandoned pastures, especially those abandoned for $>45$ years. Pastures abandoned for $>45$ years are difficult to identify because their appearance is increasingly like the surrounding forested landscape. Even when discovered, these older abandoned pastures may not be suitable for inclusion in a chronosequence study because they are more likely than recently abandoned pastures to lack adequate data on past management regimes due to ownership changes or lost or incomplete records. Nonetheless, records of historic management regimes were a strength of our study and are critical for validating results of studies using chronosequences (Walker et al. 2010).

\section{ACKNOWLEDGMENTS}

The Littlefield family, West Virginia Cooperative Fish and Wildlife Research Unit, and West Virginia Division of Natural Resources Elkins Operation Center provided housing. Numerous private landowners, the USDA Forest Service Monongahela National Forest, and West Virginia Division of Natural Resources allowed access to study sites. We thank J. Aldinger, I. Batterman, P. Bryant, A. Dalton, M. Frantz, C. Fitzmorris, N. Glover, J. Kreiser, C. Lauzau, K. Loucks, S. Malinich, A. Newman, V. Olmstead, K. Pratt, M. Roach, C. Roy, J. 
Saborse, C. Sedgwick, L. Smith, L. Stout, D. Ware, and M. Weston for long hours of work in the field. J. Anderson, G. Merovich, P. Sólymos, M. Strager, R. Tallman, and members of the Golden-winged Warbler Working Group provided valuable insights during this research. The West Virginia Division of Natural Resources Wildlife Diversity Program [grant number 013555.2.1000502W], U.S. Fish and Wildlife Service Migratory Bird Program [grant number F12AP00643], U.S. Forest Service Monongahela National Forest [grant number 12-PA11092100-020], U.S. Natural Resources Conservation Service [grant number 68-7482-12-502], and National Fish and Wildlife Foundation [grant number 10012877.1.1004706R] granted funding for this research. None of the funders required approval of the manuscript before submission or publication. This study was completed under the auspices of West Virginia University Institutional Animal Care and Use Committee protocols 07-0303 and 10-0201. Any use of trade, firm, or product names is for descriptive purposes only and does not imply endorsement by the U.S. Government.

\section{LITERATURE CITED}

Aldinger, K. R., T. M. Terhune II, P. B. Wood, D. A. Buehler, M. H. Bakermans, J. L. Confer, D. J. Flaspohler, J. L. Larkin, J. P. Loegering, K. L. Percy, A. M. Roth, and C. G. Smalling. 2015. Variables associated with nest survival of Golden-winged Warblers (Vermivora chrysoptera) among vegetation communities commonly used for nesting. Avian Conservation and Ecology 10:6.

Aldinger, K. R., and P. B. Wood. 2014. Reproductive success and habitat characteristics of Golden-winged Warblers in high-elevation pasturelands. Wilson Journal of Ornithology 126:279-287.

Aldinger, K. R., and P. B. Wood. 2015. Variables associated with detection probability, detection latency, and behavioral responses of Golden-winged Warblers (Vermivora chrysoptera). Condor 117:364-375.

Aldinger, K. R., P. B. Wood, and C. M. Johnson. 2017. Refined conservation strategies for Golden-winged Warblers in the West Virginia highlands and implications for the broader avian community. Condor 119:762-786.

Bakermans, M. H., J. L. Larkin, B. W. Smith, T. M. Fearer, and B. C. Jones. 2011. Goldenwinged Warbler habitat best management practices for forestlands in Maryland and Pennsylvania. American Bird Conservancy, The Plains, VA, USA.

Bakermans, M. H., B. W. Smith, B. C. Jones, and J. L. Larkin. 2015a. Stand and within-stand factors influencing Golden-winged Warbler use of regenerating stands in the central Appalachian Mountains. Avian Conservation and Ecology 10:10. 
Bakermans, M. H., C. L. Ziegler, and J. L. Larkin. 2015b. American Woodcock and Goldenwinged Warbler abundance and associated vegetation in managed habitats. Northeastern Naturalist 22:690-703.

Bates, D., M. Maechler, B. Bolker, and S. Walker. 2015. Fitting linear mixed-effects models using lme4. Journal of Statistical Software 67:1-48.

Bates, D., M. Maechler, B. Bolker, and S. Walker. 2017. Linear mixed-effects models using 'Eigen' and S4. R package 1.1-13. https://cran.r-project.org/package=lme4.

Best, L. B. 1978. Field Sparrow reproductive success and nesting ecology. Auk 95:9-22.

Boyce, M. S. 1992. Population viability analysis. Annual Review of Ecology and Systematics 23:481-497.

Buckland, S. T., D. R. Anderson, K. P. Burnham, J. L. Laake, D. L. Borchers, and L. Thomas. 2001. Introduction to distance sampling: estimating abundance of biological populations. Oxford University Press, Oxford, UK.

Carey, M., D. E. Burhans, and D. A. Nelson. 2008. Field Sparrow (Spizella pusilla), version 2.0. In The Birds of North America Online (P. Rodewald, Editor). Cornell Laboratory of Ornithology, Ithaca, NY, USA. https://doi.org/10.2173/bna.103.

Confer, J. L., P. Hartman, and A. Roth. 2011. Golden-winged Warbler (Vermivora chrysoptera), version 2.0. In The Birds of North America Online (P. Rodewald, Editor). Cornell Laboratory of Ornithology, Ithaca, NY, USA. https://birdsna.org/SpeciesAccount/bna/species/gowwar.

Confer, J. L., and K. Knapp. 1981. Golden-winged Warblers and Blue-winged Warblers: the relative success of a habitat specialist and a generalist. Auk 98:108-114.

Cook, W. M., J. Yao, B. L. Foster, R. D. Holt, and L. B. Patrick. 2005. Secondary succession in an experimentally fragmented landscape: community patterns across space and time. Ecology 86:1267-1279.

Core, E. L. 1949. Original treeless areas in West Virginia. Journal of the Elisha Mitchell Scientific Society 65:306-310.

Cramer, V. A., R. J. Hobbs, and R. J. Standish. 2008. What's new about old fields? Land abandonment and ecosystem assembly. Trends in Ecology and Evolution 23:104-112.

Crawford, D. L., R. W. Rohrbaugh, A. M. Roth, J. D. Lowe, S. B. Swarthout, and K. V. Rosenberg. 2016. Landscape-scale habitat and climate correlates of breeding Goldenwinged and Blue-winged warblers. In Golden-winged Warbler Ecology, Conservation, and Habitat Management (H. M. Streby, D. E. Andersen, and D. A. Buehler, Editors). Studies in Avian Biology 49:41-66.

Davies, K. W., M. Varva, B. Schultz, and N. Rimbey. 2014. Implications of longer term rest from grazing in the sagebrush steppe. Journal of Rangeland Applications 1:14-34.

Davis, M. A., L. Bier, E. Bushelle, C. Diegel, A. Johnson, and B. Kujala. 2005. Non-indigenous grasses impede woody succession. Plant Ecology 178:249-264. 
DeGraaf, R. M., and M. Yamasaki. 2003. Options for managing early-successional forest and shrubland bird habitats in the northeastern United States. Forest Ecology and Management 185:179-191.

Dettmers, R., D. A. Buehler, J. G. Bartlett, N. A. Klaus. 1999. Influence of point count length and repeated visits on habitat model performance. Journal of Wildlife Management 63:815-823.

ESRI. 2011. ArcGIS Desktop: Release 10. Environmental Systems Research Institute, Redlands, CA, USA.

Evans, J. R., G. E. D’ Souza, A. Collins, C. Brown, and M. Sperow. 2011. Determining consumer perceptions of and willingness to pay for Appalachian grass-fed beef: an experimental economics approach. Agricultural and Resource Economics Review 40:233-250.

Farnsworth, G. L., K. H. Pollock, J. D. Nichols, T. R. Simons, J. E. Hines, and J. R. Sauer. 2002. A removal model for estimating detection probabilities from point count surveys. Auk 119:414-425.

Giuliano, W. M., and S. E. Daves. 2002. Avian response to warm-season grass use in pasture and hayfield management. Biological Conservation 106:1-9.

Golden-winged Warbler Working Group. 2013. Best management practices for Golden-winged Warbler habitat on abandoned farmlands in the Appalachians. http://www.gwwa.org/plan/.

Guldin, J. M., W. H. Emmingham, S. A. Carter, and D. A. Saugey. 2007. Silvicultural practices and management of habitat for bats. Pgs. 177-205 in Bats in Forests Conservation and Management (M. J. Lacki, J. P. Hayes, and A. Kurta, Editors). Johns Hopkins University Press, Baltimore, MD, USA.

Huffman, R. D. 1997. Effects of residual overstory on bird use and aspen regeneration in aspen harvest sites in Tamarac National Wildlife Refuge, Minnesota. Master's thesis, West Virginia University, Morgantown, WV, USA.

Hutto, R. L. 2016. Should scientists be required to use a model-based solution to adjust for possible distance-based detectability bias? Ecological Applications 26:1287-1294.

James, F. C., and H. H. Shugart, Jr. 1970. A quantitative method of habitat description. Audubon Field Notes 24:727-736.

Kardol, P., T. M. Bezemer, and W. H. van der Putten. 2006. Temporal variation in plant-soil feedback controls succession. Ecology Letters 9:1080-1088.

King, D. I., R. B. Chandler, C. Smalling, R. Trubey, R. Raudales, and T. Will. 2016. Nonbreeding Golden-winged Warbler habitat: status, conservation, and needs. In Goldenwinged Warbler Ecology, Conservation, and Habitat Management (H. M. Streby, D. E. Andersen, and D. A. Buehler, Editors). Studies in Avian Biology 49:29-38.

King, D. I., and S. Schlossberg. 2014. Synthesis of the conservation value of the early-succession stage in forests of eastern North America. Forest Ecology and Management 324:186-195. 
Klaus, N. A. and D. A. Buehler. 2001. Golden-winged Warbler breeding habitat characteristics and nest success in clearcuts in the southern Appalachian Mountains. Wilson Bulletin 113:297-301.

Kramer, G. R., H. M. Streby, S. M. Peterson, J. A. Lehman, D. A. Buehler, P. B. Wood, D. J. McNeil, J. L. Larkin, and D. E. Andersen. Nonbreeding isolation and population-specific migration patterns among three populations of Golden-winged Warblers. Condor 119:108-121.

Latham, R. E. 2003. Shrubland longevity and rare plant species in the Northeast (USA). Forest Ecology and Management 185:21-39.

Litvaitis, J. A. 1993. Response of early successional vertebrates to historic changes in land use. Conservation Biology 7:866-873.

Martin, K. J., R. S. Lutz, and M. Worland. 2007. Golden-winged Warbler habitat use and abundance in northern Wisconsin. Wilson Journal of Ornithology 119:523-532.

McDermott, M. E., and P. B. Wood. 2009. Short- and long-term implications of clearcut and two-age silviculture for conservation of breeding forest birds in the central Appalachians, USA. Biological Conservation 142:212-220.

McDermott, M. E., P. B. Wood, G. W. Miller, and B. T. Simpson. 2011. Predicting breeding bird occurrence by stand- and microhabitat-scale features in even-aged stands in the central Appalachians. Forest Ecology and Management 261:373-380.

McLauchlan, K. 2006. The nature and longevity of agricultural impacts on soil carbon and nutrients: a review. Ecosystems 9:1364-1382.

Morin, R. S., G. W. Cook, C. J. Barnett, B. J. Butler, S. J. Crocker, M. A. Hatfield, C. M. Kurtz, T. W. Lister, W. G. Luppold, W. H. McWilliams, P. D. Miles, M. D. Nelson, C. H. Perry, R. J. Piva, J. E. Smith, J. A. Westfall, R. H. Widmann, and C. W. Woodall. 2016. West Virginia forests, 2013. U.S. Department of Agriculture Forest Service Resource Bulletin NRS-105.

Parody, J. M., F. J. Cuthbert, and E. H. Decker. 2001. The effect of 50 years of landscape change on species richness and community composition. Global Ecology and Biogeography 10:305-313.

Patton, L. L., D. S. Maehr, J. E. Duchamp, S. Fei, J. W. Gassett, and J. L. Larkin. 2010. Do the Golden-winged Warbler and Blue-winged Warbler exhibit species-specific differences in their breeding habitat use? Avian Conservation and Ecology 5:2.

Piché, N., and D. L. Kelting. 2015. Recovery of soil productivity with forest succession on abandoned agricultural land. Restoration Ecology 23:645-654.

Prestemon, J. P., D. N. Wear, and M. O. Foster. 2015. The global position of the U.S. forest products industry. U.S. Department of Agriculture Forest Service General Technical Report SRS-204.

R Development Core Team. 2017. R: A language and environment for statistical computing. Version 3.4.1. R Foundation for Statistical Computing. Vienna, Austria. www.rproject.org. 
Ralph, C. J., J. R. Sauer, and S. Droege (Editors). 1995. Monitoring bird populations by point counts. U.S. Department of Agriculture Forest Service General Technical Report PSWGTR-149.

Rohrbaugh, R. W., D. A. Buehler, S. B. Swarthout, D. I. King, J. L. Larkin, K. V. Rosenberg, A. M. Roth, R. Vallender, and T. Will. 2016. Conservation perspectives: review of new science and primary threats to Golden-winged Warblers. In Golden-winged Warbler Ecology, Conservation, and Habitat Management (H. M. Streby, D. E. Andersen, and D. A. Buehler, Editors). Studies in Avian Biology 49:207-215.

Rosenberg, K. V., J. A. Kennedy, R. Dettmers, R. P. Ford, D. Reynolds, J. D. Alexander, C. J. Beardmore, P. J. Blancher, R. E. Bogart, G. S. Butcher, A. F. Camfield, et al. 2016. Partners in Flight Landbird Conservation Plan: 2016 Revision for Canada and Continental United States. Partners in Flight Science Committee.

Roth, A. M., and S. Lutz. 2004. Relationship between territorial male Golden-winged Warblers in managed aspen stands in northern Wisconsin, USA. Forest Science 50:153-161.

Roth, A. M., R. W. Rohrbaugh, K. R. Aldinger, M. H. Bakermans, S. Barker Swarthout, D. A. Buehler, J. L. Confer, D. Crawford, C. Friis, R. M. Fowlds, J. L. Larkin, J. Loegering, J. D. Lowe, M. Piorkowski, K. V. Rosenberg, C. Smalling, T. M. Terhune, R. Vallender, T. Will, and P. B. Wood. 2012. Golden-winged Warbler breeding season conservation plan. In Golden-winged Warbler Status Review and Conservation Plan (A. M. Roth, R. W. Rohrbaugh, T. Will, and D. A. Buehler, Editors). www.gwwa.org/plan.

Sauer, J. R., D. K. Niven, J. E. Hines, D. J. Ziolkowski, Jr, K. L. Pardieck, J. E. Fallon, and W. A. Link. 2017. The North American Breeding Bird Survey, Results and Analysis 1966 2015. Version 2.07.2017 USGS Patuxent Wildlife Research Center, Laurel, MD, USA.

Schieltz, J. M., and D. I. Rubenstein. 2016. Evidence based review: positive versus negative effects of livestock grazing on wildlife. What do we really know? Environmental Research Letters 11:11.

Skaug, H. J., D. A. Fournier, B. Bolker, A. Magnusson, and A. Nielsen. 2016. Generalized linear mixed models using AD Model Builder. R package 0.8.3.3. http://glmmadmb.r-forge.rproject.org.

Smithson, M., and J. Verkuilen. 2006. A better lemon squeezer? Maximum-likelihood regression with beta-distributed dependent variables. Psychological Methods 11:54-71.

Sólymos, P., S. M. Matsuoka, E. M. Bayne, S. R. Lele, P. Fontaine, S. G. Cumming, D. Stralberg, F. K. A. Schmiegelow, and S. J. Song. 2013. Calibrating indices of avian density from non-standardized survey data: making the most of a messy situation. Methods in Ecology and Evolution 4: 1047-1058.

Sólymos, P., M. Moreno, and S. R. Lele. 2016. Detect: analyzing wildlife data with detection error. R package 0.4-0. https://cran.r-project.org/package=detect.

Stephens, G. R., and J. S. Ward. 1992. Sixty years of natural change in unmanaged mixed hardwood forests. Bulletin 902. Connecticut Agricultural Experimental Station, New Haven, CT, USA. 
Strausbaugh, P. D., and E. L. Core. 1978. Flora of West Virginia. Seneca Books Inc., Grantsville, WV, USA.

Swanson, M. E., J. F. Franklin, R. L. Beschta, C. M. Crisafulli, D. A. DellaSala, R. L. Hutto, D. B. Lindenmayer, and F. J. Swanson. 2010. The forgotten stage of forest succession: early-successional ecosystems on forest sites. Frontiers in Ecology and the Environment 9:117-125.

Teague, W. R., S. L. Dowhower, S. A. Baker, N. Haile, P. B. DeLaune, D. M. Conover. 2011. Grazing management impacts on vegetation, soil biota and soil chemical, physical and hydrological properties in tall grass prairie. Agriculture, Ecosystems and Environment 141:310-322.

U.S. Farm Service Agency. 2017. Conservation Reserve Program. U.S. Department of Agriculture Farm Service Agency, Washington, DC, USA.

U.S. Forest Service. 2011. Monongahela National Forest datasets: Range allotments 2011. U.S. Department of Agriculture Forest Service, Monongahela National Forest, Elkins, WV, USA.

U.S. Geological Survey, Gap Analysis Program (GAP). 2016. Protected areas database of the United States (PAD-US), version 1.4 May 2016 Combined Feature Class.

U.S. National Agricultural Statistics Service. 2017. West Virginia Annual Bulletin No. 48. U.S. Department of Agriculture National Agricultural Statistics Service West Virginia Field Office, Charleston, WV, USA.

U.S. Natural Resources Conservation Service. 2012. Working lands for wildlife. U.S. Department of Agriculture Natural Resources Conservation Service, Washington, DC, USA.

www.nrcs.usda.gov/wps/portal/nrcs/detailfull/national/programs/financial/whip/?cid=stel prdb1046990.

Vallender, R., and R. D. Bull. 2016. Genetic insights into hybridization between Golden-winged and Blue-winged Warblers. In Golden-winged Warbler Ecology, Conservation, and Habitat Management (H. M. Streby, D. E. Andersen, and D. A. Buehler, Editors). Studies in Avian Biology 49:67-80.

Walker, L. R., D. A. Wardle, R. D. Bardgett, and B. D. Clarkson. 2010. The use of chronosequences in studies of ecological succession and soil development. Journal of Ecology 98:725-736.

West Virginia Division of Natural Resources. 2015. West Virginia State Wildlife Action Plan. West Virginia Division of Natural Resources, Wildlife Resources Section, South Charleston, WV, USA. http://www.wvdnr.gov/2015\%20West\%20Virginia\%20State\%20 Wildlife\%20Action\%20Plan\%20Submittal.pdf.

Widmann, R. H., G. W. Cook, C. J. Barnett, B. J. Butler, D. M. Griffith, M. A. Hatfield, C. M. Kurtz, R. S. Morin, W. K. Moser, C. H. Perry, R. J. Piva, R. Riemann, and C. W. Woodall. West Virginia's forests 2008. U.S. Department of Agriculture Forest Service Resource Bulletin NRS-61. 


\section{TABLES}

Table 1. Shrubland-nesting bird species (Sauer et al. 2017) included in our species richness analysis that were detected during 10 -min, 100 -m radius point counts on pastures $(\mathrm{n}=68)$ in Monroe, Pendleton, Pocahontas, Randolph, and Tucker counties, WV during 2008-2014.

\begin{tabular}{|c|c|c|c|}
\hline Common name & Scientific name & BBS trend $^{1}$ & Occurrence $^{2}$ \\
\hline Chestnut-sided Warbler & Setophaga pensylvanica & +- & $95.0 \pm 1.0$ \\
\hline Eastern Towhee & Pipilo erythrophthalmus & -- & $93.0 \pm 2.4$ \\
\hline Indigo Bunting & Passerina cyanea & -- & $92.4 \pm 2.4$ \\
\hline Field Sparrow & Spizella pusilla & -- & $86.0 \pm 3.2$ \\
\hline Gray Catbird & Dumetella carolinensis & +- & $68.8 \pm 4.8$ \\
\hline Common Yellowthroat & Geothlypis trichas & -- & $66.2 \pm 2.7$ \\
\hline American Goldfinch & Spinus tristis & -- & $59.6 \pm 3.2$ \\
\hline Golden-winged Warbler & Vermivora chrysoptera & -- & $47.3 \pm 7.3$ \\
\hline Song Sparrow & Melospiza melodia & -- & $45.0 \pm 4.9$ \\
\hline Brown Thrasher & Toxostoma rufum & -- & $39.6 \pm 8.5$ \\
\hline House Wren & Troglodytes aedon & -- & $20.6 \pm 1.7$ \\
\hline Northern Cardinal & Cardinalis cardinalis & ++ & $18.0 \pm 3.1$ \\
\hline Yellow Warbler & Setophaga petechia & -- & $15.1 \pm 2.8$ \\
\hline Mourning Warbler & Geothlypis philadelphia & +- & $11.8 \pm 4.0$ \\
\hline White-eyed Vireo & Vireo griseus & +- & $5.2 \pm 1.5$ \\
\hline Alder Flycatcher & Empidonax alnorum & ++ & $4.1 \pm 1.8$ \\
\hline Blue-winged Warbler & Vermivora cyanoptera & +- & $3.8 \pm 1.3$ \\
\hline Willow Flycatcher & Empidonax traillii & +- & $3.7 \pm 1.6$ \\
\hline Carolina Wren & Thryothorus ludovicianus & ++ & $2.8 \pm 1.5$ \\
\hline Yellow-breasted Chat & Icteria virens & -- & $2.3 \pm 1.1$ \\
\hline American Woodcock & Scolopax minor & +- & $2.2 \pm 1.1$ \\
\hline Northern Bobwhite & Colinus virginianus & -- & $1.1 \pm 1.1$ \\
\hline
\end{tabular}

${ }^{1}$ North American Breeding Bird Survey population trend for Appalachian Mountains bird conservation region during 1966-2015 ("++ " = increasing, "+ - = stable, " - " = decreasing). ${ }^{2}$ Mean ( \pm standard error) annual percent of pastures where we detected an adult male or female of each species at least once (excluding flyovers) with 10-min, 100-m radius point counts during 2008-2014. 
Table 2. Constant or intercept-only models of the two components of detection probability: availability (i.e., time-removal model), the probability that an individual bird presents a cue and is thus available for detection, and perceptibility (i.e., distance-sampling model), the probability than an observer detects an individual bird given that the bird is available. Models for both species had significant intercepts, suggesting imperfect detection of males during point counts in West Virginia during 2008-2014.

\begin{tabular}{llrrrr}
\hline Species & $\begin{array}{l}\text { Detection probability } \\
\text { component }\end{array}$ & $\begin{array}{l}\text { Intercept } \\
\text { estimate }\end{array}$ & $\begin{array}{l}\text { Standard } \\
\text { error }\end{array}$ & $\mathrm{z}$ & $P$ \\
\hline Golden-winged Warbler & Availability & -0.865 & 0.096 & -9.022 & $<0.001$ \\
& Perceptibility & -0.555 & 0.067 & -8.315 & $<0.001$ \\
Field Sparrow & Availability & -0.957 & 0.053 & -18.230 & $<0.001$ \\
& Perceptibility & -0.480 & 0.040 & -12.130 & $<0.001$ \\
\hline
\end{tabular}


Table 3. Summary statistics for Poisson lognormal mixed effect models of male Field Sparrow density, male Golden-winged Warbler density, and shrubland-nesting bird richness in West Virginia during 2008-2014. The Field Sparrow density model included a linear fixed effect term for years since pasture abandonment (YSA) and the Golden-winged Warbler density model and the shrubland-nesting bird richness model included linear and quadratic fixed effect terms for YSA. All models included a random intercept for pasture ID and a random slope for pasture size. We scaled YSA (range: 0-1) and pasture size (range: $0-1$ ) to aid in model convergence.

\begin{tabular}{|c|c|c|c|c|c|c|c|}
\hline \multirow[b]{2}{*}{ Model } & \multirow{2}{*}{$\begin{array}{l}\text { Fixed } \\
\text { effect }\end{array}$} & \multirow[b]{2}{*}{ Estimate } & \multirow{2}{*}{$\begin{array}{l}\text { Standard } \\
\text { error }\end{array}$} & \multirow[b]{2}{*}{$\mathrm{Z}$} & \multirow[b]{2}{*}{$P$} & \multicolumn{2}{|c|}{$\begin{array}{c}\text { Random effect } \\
\text { standard deviation }\end{array}$} \\
\hline & & & & & & Intercept & Slope \\
\hline \multirow{3}{*}{$\begin{array}{l}\text { Golden-winged } \\
\text { Warbler }\end{array}$} & Intercept & -2.258 & 0.335 & -6.740 & $<0.001$ & 0.806 & 9.6072 \\
\hline & YSA & 7.339 & 2.799 & 2.622 & 0.009 & & \\
\hline & $\mathrm{YSA}^{2}$ & -9.598 & 4.509 & -2.129 & 0.033 & & \\
\hline \multirow[t]{2}{*}{ Field Sparrow } & Intercept & 0.050 & 0.058 & 0.861 & 0.389 & 0.351 & 3.095 \\
\hline & YSA & -0.939 & 0.351 & -2.676 & 0.007 & & \\
\hline \multirow{3}{*}{$\begin{array}{l}\text { Shrubland-nesting } \\
\text { bird richness }\end{array}$} & Intercept & 1.791 & 0.036 & 50.210 & $<0.001$ & 0.096 & 0.772 \\
\hline & YSA & -0.090 & 0.445 & -0.200 & 0.839 & & \\
\hline & $\mathrm{YSA}^{2}$ & -0.104 & 0.778 & -0.130 & 0.893 & & \\
\hline
\end{tabular}


Table 4. Summary statistics for mixed effect beta regression models of shrubland cover, herbaceous cover, and forest cover from a chronosequence of pastures in West Virginia in 2011. The herbaceous cover and forest cover models included a linear fixed effect term for years since pasture abandonment (YSA) and the shrubland cover model included a linear and quadratic fixed effect term for YSA. All models included a random slope for pasture size. We scaled YSA (range: $0-1$ ) and pasture size (range: $0-1$ ) to aid in model convergence.

\begin{tabular}{|c|c|c|c|c|c|c|}
\hline Model & $\begin{array}{l}\text { Fixed } \\
\text { effect }\end{array}$ & Estimate & $\begin{array}{l}\text { Standard } \\
\text { error }\end{array}$ & $\mathrm{Z}$ & $P$ & $\begin{array}{l}\text { Random intercept } \\
\text { standard deviation }\end{array}$ \\
\hline Shrubland & Intercept & -0.557 & 0.140 & -3.970 & $<0.001$ & 0.001 \\
\hline \multirow[t]{2}{*}{ cover } & YSA & 3.552 & 1.675 & 2.120 & 0.034 & \\
\hline & $\mathrm{YSA}^{2}$ & -5.905 & 2.414 & -2.450 & 0.014 & \\
\hline \multirow{2}{*}{$\begin{array}{l}\text { Herbaceous } \\
\text { cover }\end{array}$} & Intercept & -1.012 & 0.151 & -6.710 & $<0.001$ & 0.006 \\
\hline & YSA & -2.157 & 0.737 & -2.930 & 0.003 & \\
\hline \multirow[t]{2}{*}{ Forest cover } & Intercept & -0.783 & 0.119 & -6.600 & $<0.001$ & 0.001 \\
\hline & YSA & 2.528 & 0.506 & 5.000 & $<0.001$ & \\
\hline
\end{tabular}




\section{FIGURES}

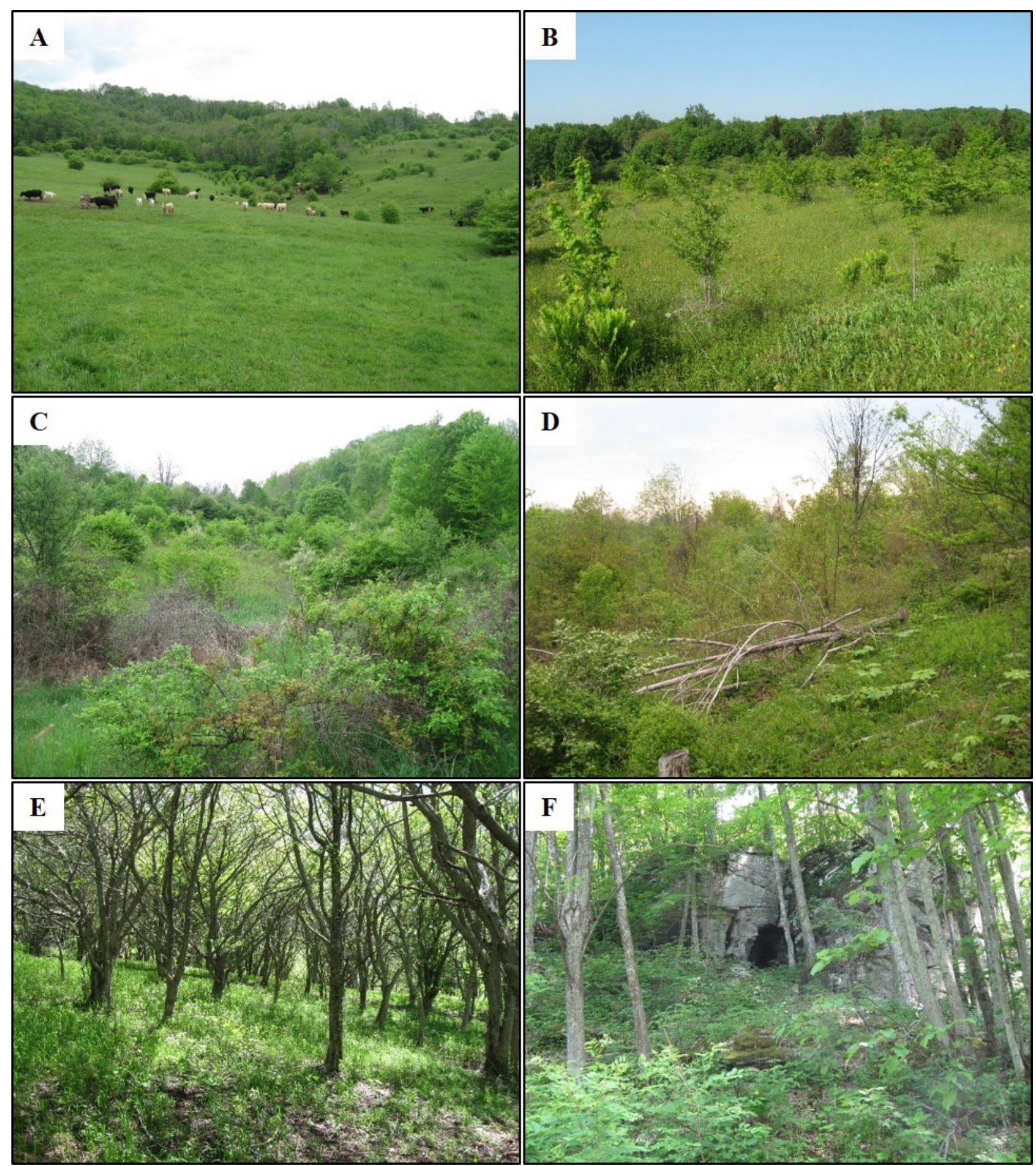

Figure 1. Examples from our 62-year chronosequence of abandoned pastures in West Virginia during 2008-2014. $\mathrm{A}=0$ years since abandonment, $\mathrm{B}=7$ years, $\mathrm{C}=17$ years, $\mathrm{D}=22$ years, $\mathrm{E}=$ 39 years, $\mathrm{F}=62$ years. 

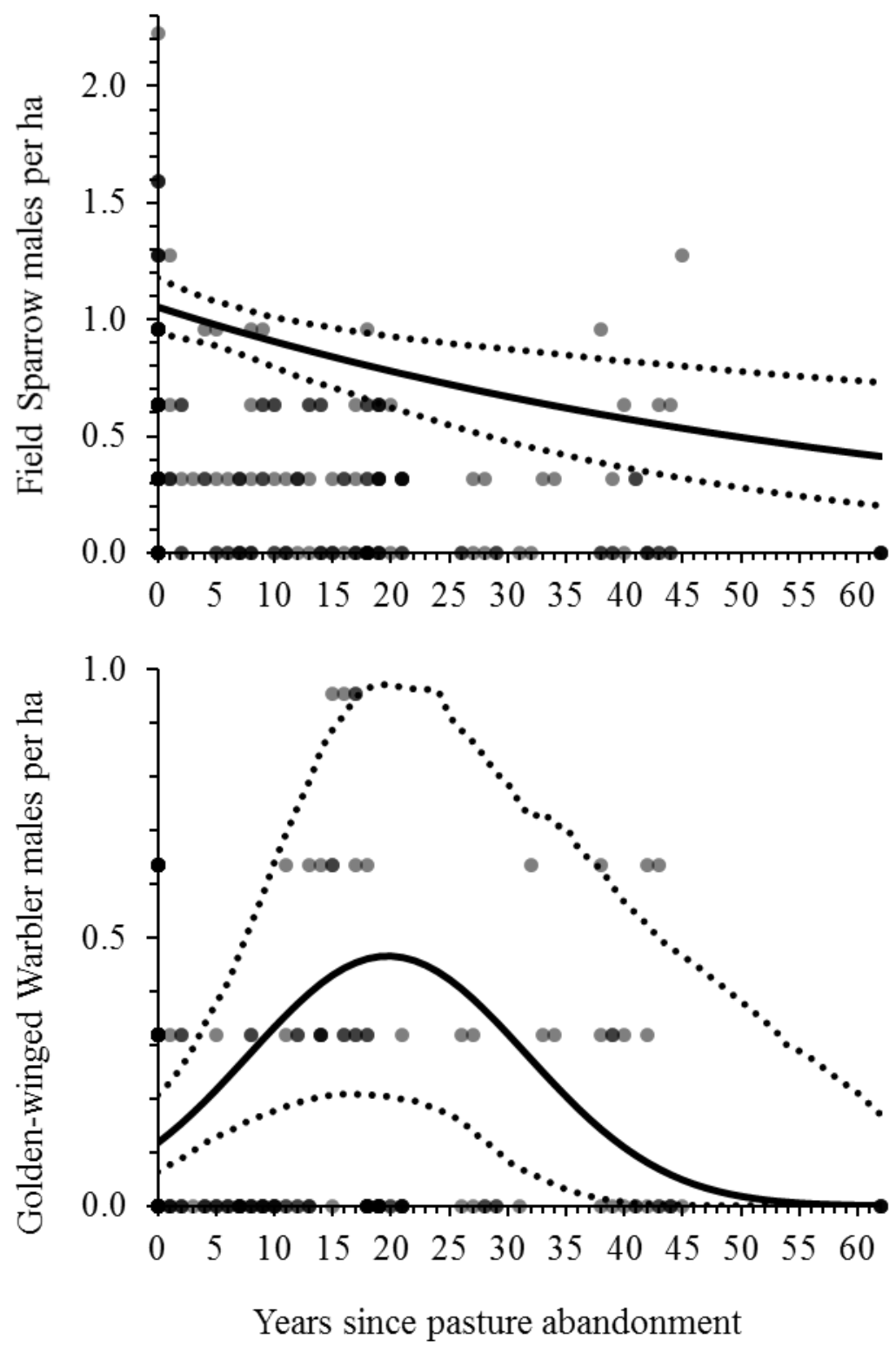

Figure 2. Predicted mean male density (solid black line) of Field Sparrow (top panel) and Golden-winged Warbler (bottom panel) adjusted for detection probability based on avian point counts from a chronosequence (range 0-62 years) of pastures $(n=68)$ in West Virginia during 2008-2014. Dotted lines represent 95\% confidence intervals. Gray circles represent raw observed densities (count of males per 3.14 ha) and darker shades represent overlapping circles. Note different $y$-axis scales. 

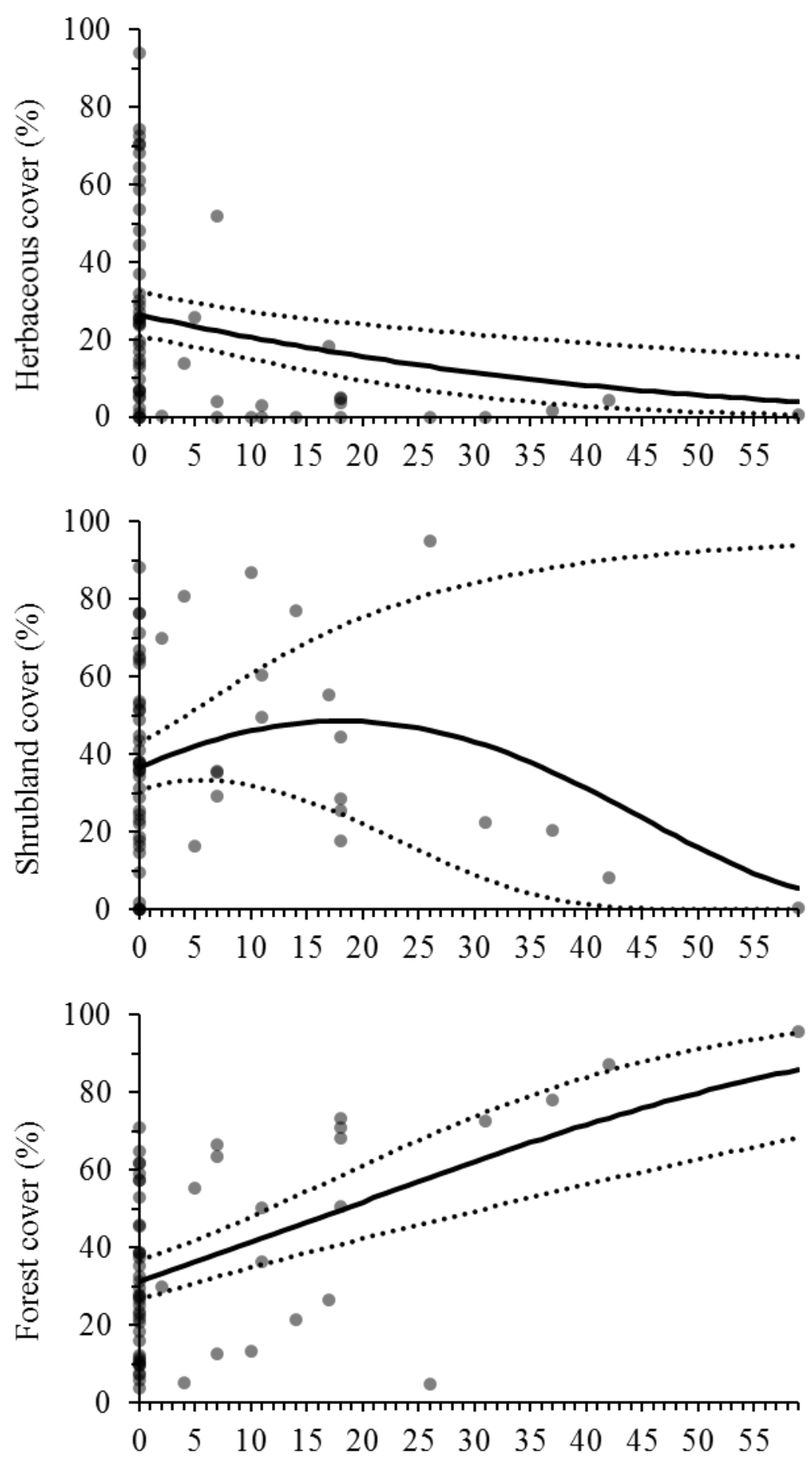

Years since pasture abandonment

Figure 3. Predicted mean cover (solid black line) of herbaceous (top panel), shrubland (middle panel), and forest (bottom panel) as a function of years since pasture abandonment (range $=0-59$ years) based on land cover on individual pastures $(n=68)$ in West Virginia in 2011. Dotted lines represent the 95\% confidence interval. Gray circles represent observed values for individual pastures and darker shades representing overlapping circles. 


\title{
CHAPTER 6. HIGH NEST SURVIVAL DURING THE BREEDING SEASON MAY OFFSET OTHER LIMITING FACTORS FOR LOCAL POPULATIONS OF GOLDEN- WINGED WARBLERS
}

\author{
ABSTRACT \\ Golden-winged Warbler (Vermivora chrysoptera) populations breeding in the \\ Appalachian Mountains region have decreased significantly for decades. Primary threats include \\ decreasing amounts of quality breeding habitat, competition and hybridization with Blue-winged \\ Warblers (V. cyanoptera), and high mortality during the non-breeding season. Our ability to \\ confidently identify population limiting factors has been hampered by the common use of cross- \\ sectional rather than longitudinal study designs and analyses. Therefore, we monitored breeding \\ populations of Golden-winged Warblers on 6 pastures in West Virginia for 5-7 years during \\ 2008-2014 and investigated variation in nest placement, nest survival, and density over time. We \\ evaluated competing hypotheses considering land cover, management regime, spatial location, \\ time, and Vermivora warbler demographic covariates as sources of variation in our models. \\ Golden-winged Warblers did not change nest placement behavior ( $n=109$ nests) because of \\ mechanical vegetation management intended to maintain shrubland cover type on our pastures. \\ Nest daily survival rate ( $\mathrm{n}=123$ nests) was higher on pastures in our southern study area than \\ our northern study area and was positively associated with proportion of territory-scale actively- \\ managed shrubland cover type, shrubland patch size, and nest- and territory-scale elevation. In \\ our final analysis, we demonstrated that local Golden-winged Warbler population trends were \\ associated with pasture-scale nest survival. We infer that individuals from local populations \\ likely all faced similar conditions during the non-breeding season because of the small \\ geographic extent of our study area. Thus, providing high-quality nesting habitat in West \\ Virginia may offset mortality during the non-breeding season and result in stable breeding \\ populations. Such a conservation strategy may benefit the species while conservation efforts \\ develop in migration and wintering areas. Overall, our results help to justify, inform, and adapt \\ state and regional Golden-winged Warbler conservation efforts on the breeding grounds.
}

Keywords: grazing, interaction, management, pasture, population regulation, Vermivora 


\section{INTRODUCTION}

Golden-winged Warbler (Vermivora chrysoptera) populations in the Appalachian Mountains segment of their breeding range have decreased significantly for decades (Hill and Hagan 1991, Rosenberg et al. 2016, Sauer et al. 2017). Forest succession (Gill 1980), land-use change (Confer and Knapp 1979), lack of natural and anthropogenic disturbances (Hunter et al. 2001), patch- and landscape-level vegetation structure and composition (Lehman 2017), Brownheaded Cowbird (Molothrus ater) brood parasitism (Confer et al. 2003), topographic position (Confer et al. 2010), and competition (Confer et al. 2003) and hybridization (Vallender et al. 2009) with Blue-winged Warblers (Vermivora cyanoptera) were among the breeding-grounds factors implicated in the population decrease. A principal conservation tenet therefore has been to increase populations by managing breeding habitat using guidelines derived from studies that linked certain habitat characteristics with increased demographic rates (Buehler et al. 2007, Roth et al. 2012, Golden-winged Warbler Working Group 2013). Despite a growing body of literature on the species' response to these management efforts (Kubel and Yahner 2008, Aldinger and Wood 2014, Bakermans et al. 2015a, 2015b, McNeil et al. 2017), rigorous evaluations of management response with a temporal component, such as in before-after, control-impact, or longitudinal designs, are rare (Streby et al. 2018). In fact, investigations of temporal trends of any Golden-winged Warbler demographic rates are relatively scarce overall considering the degree to which the species has been studied (but see Gill 1980, 1997).

Recent evidence suggests that Golden-winged Warbler populations breeding in the Appalachian Mountains may be limited primarily by factors during the non-breeding season (Kramer et al. 2018). These new findings challenge long-held views on Golden-winged Warbler conservation by suggesting that the path to species recovery may need to focus on addressing deforestation in northern South America where the Appalachian Mountains Golden-winged Warblers winter (Hansen et al. 2010). Nonetheless, maintaining or increasing quality breeding habitat for Golden-winged Warblers in the Appalachian Mountains region arguably remains important and is likely to continue because (1) the amount of shrubland and young forest cover type is historically low and decreasing (King and Schlossberg 2014), (2) conditions across a migratory species' range may change unpredictably with consequences for the relative importance of different limiting factors (Holmes 2007), and (3) other species of conservation concern depend on similar vegetation communities (Bakermans et al. 2015b, Aldinger et al. 
2017). Therefore, rather than discouraging an emphasis on breeding grounds research and management, this new evidence ought to encourage researchers to rigorously study management response, or lack thereof, as a method of evaluating the relative strength of population limiting factors and continue to apply findings within an adaptive management framework to improve existing guidelines (Golden-winged Warbler Working Group 2013). For example, multiple researchers in the Appalachian Mountains region report considerable variation in trends among local breeding populations in patches of managed shrubland and young forest across relatively short distances (Pennsylvania, D. J. McNeil, pers. comm.; New York, Confer et al. 2010; West Virginia, this study). Presumably, geographically close populations would use similar migratory routes and wintering areas and experience similar survival during the non-breeding season (Kramer et al. 2018). An important question then is whether breeding season characteristics are associated with variation in trends among local populations.

Our overarching goal was to evaluate if conditions during the breeding season, some influenced by biological (i.e., livestock grazing) and mechanical (i.e., hand-cutting and brush hogging) vegetation management, were associated with Golden-winged Warbler nesting behavior and survival and adult population trends. We monitored Golden-winged Warbler populations for 5-7 years on 6 pastures where biological and mechanical vegetation management were used to maintain shrubland cover. Specifically, we first modeled nest survival as a function of land cover, management regime, spatial location, and time covariates. In addition to an assessment of potential effects of management regime on reproduction, nest survival analysis was a preliminary step to derive a parameter for our later objective to evaluate population trends over time. Second, we modeled nest distance from mechanical vegetation management as a function of years since management as an index of Golden-winged Warbler behavioral response to mechanical vegetation management. Mechanical vegetation management was designed to maintain rather than create new shrubland cover type, so we expected only a short-term response wherein Golden-winged Warblers would shift nest placement away from mechanical vegetation management for 1-2 years post-management then resume random nest placement relative to mechanical vegetation management. Finally, our third objective was to model Golden-winged Warbler density over time (i.e., population trend) as a function of land cover, management regime, spatial location, and Vermivora warbler demographic covariates. We expected that the overall Golden-winged Warbler population would decrease based on results from the North 
American Breeding Bird Survey (Sauer et al. 2017). However, we also expected variation in population trends based on variation in characteristics known to be associated with breeding habitat quality for Golden-winged Warblers. From this analysis, we draw inference about the efficacy of conservation efforts among pastures and relative to forces driving population trends at other times during the species' annual cycle (Kramer et al. 2018).

\section{METHODS}

\section{Study Area}

We studied breeding populations of Golden-winged Warblers on three pastures in Randolph County, West Virginia (3855'34"N, 7944'52"W) during 2008-2014, two pastures in Pocahontas County, West Virginia (38¹9'5"N, 8005'29"W) during 2009-2014, and one pasture in Pocahontas County, West Virginia (38²1'23"N 8004'52"W) during 2010-2014 for a total of six pastures monitored. We classified the Pocahontas and Randolph county pastures, which were separated by $70 \mathrm{~km}$, as our southern and northern study areas, respectively. We selected pastures based on known breeding populations of Golden-winged Warblers. Five pastures were on the Monongahela National Forest and one was privately-owned. Pasture fences enclosed 22-179 ha of a patchy mosaic of grasses, forbs, shrubs, saplings, and scattered canopy trees at elevations of 809-1,174 $\mathrm{m}$. Some shrubland cover type extended beyond the fenced boundary and was treated as part of the pasture for the purposes of this study. Pastures were bordered by mature forest cover type characterized by a uniform and closed canopy of deciduous trees resulting in sparse plant growth in the understory layer. Pocahontas and Randolph counties are 91\% and 90\% forested, respectively (West Virginia Division of Forestry 2010). Thus, pastures were discrete patches of herbaceous and shrubland cover types in a heavily-forested landscape.

\section{Pasture Management Regimes}

Pastures on the Monongahela National Forest (MNF, $n=5$ ) were managed to provide open areas for livestock forage, wildlife habitat, visual diversity, and dispersed recreation (U.S. Forest Service 2006). To achieve these goals, Forest Service staff prescribed a combination of livestock grazing during 15 May - 1 October at stocking rates of 1.2-2.4 ha (mean \pm standard error [SE] = $1.8 \pm 0.1$ ha) of usable forage per animal unit (bull or cow-calf pair; D. S. Gibson and C. W. McDaniels personal communication) and mechanical control of vegetation (U.S. Forest Service 2006). All five MNF pastures were grazed by cattle each year, but during our 
study one pasture was increased in size by expanding the boundary fence and one pasture was decreased in size by using exclusion fencing. One pasture was grazed by cattle and horses, but the total combined stocking rate was still $1.6 \pm 0.1$ ha, which was within the recommended $1.2-$ 2.4 ha of usable forage per animal unit. Mechanical vegetation management occurred during Fall 2008 on our MNF pastures in Randolph County and during Fall 2009 on our MNF pastures in Pocahontas County. Areas targeted for management were characterized by a uniform closedcanopy thicket of shrubs, usually hawthorn (Crataegus spp), autumn olive (Elaeagnus umbellata), and multiflora rose (Rosa multiflora), where (1) optimum Golden-winged Warbler nesting cover was disappearing due to vegetative succession (Confer et al. 2011), (2) livestock forage was absent due to shading, and (3) shrubs formed a physical barrier to livestock. Management consisted of hand-cutting shrubs and trees with chainsaws and brush hogging with a compact track loader or tractor with brush hog attachment (Figure 1). We used information from published literature and pre-treatment vegetation data collected at Golden-winged Warbler nests and territories to develop management prescriptions because management occurred prior to the publication of Golden-winged Warbler best management practices (Roth et al. 2012, Goldenwinged Warbler Working Group 2013). Target shrub cover was 30-60\% post-management (Confer et al. 2003, Bulluck and Buehler 2008), which coincided with best management practices later published for the species (30-70\% cover, Golden-winged Warbler Working Group 2013).

The private-land pasture in Randolph County had not been grazed or otherwise managed to our knowledge since circa 1970 based on review of historic imagery and interviews (W. A. Tolin, pers. comm.). Before abandonment, this privately-owned pasture was estimated to be 106 ha in size. At the initiation of our study in 2008, 7 ha remained as shrubland cover type seemingly in a state of arrested succession for unknown reasons. Thus, this pasture served as a control.

Each year we delineated the amount of pasture area accessible to be grazed by livestock during the grazing season. Mechanical vegetation management shapefiles were provided by the US Forest Service and represented areas demarcated by flagging within which mechanical vegetation management occurred. Using this information, we digitized and classified all shrubland cover within pastures annually using all possible management scenarios $(\mathrm{n}=8$ combinations): grazed and managed (GM), grazed and unmanaged (Gm), ungrazed and managed 
(gM), all grazed (GMm), all managed (GgM), all ungrazed (gMm), all unmanaged (Ggm), and ungrazed and unmanaged (gm). These 8 combinations are not mutually exclusive. For example, the amount of shrubland cover type classified as "grazed and managed" (GM) was a subset of the amount of shrubland cover type classified as “all grazed” (GMm).

\section{Land Cover}

We used manually-digitized land cover data from Aldinger et al. (2017) to assess the cover types within a 5-km radius around fenced pasture boundaries. Cover types included barren (no vegetation), forest (nearly 100\% closed canopy consisting of trees $>10 \mathrm{~cm}$ diameter at breast height $[\mathrm{dbh}]$ ), herbaceous (dominated by grasses and forbs with $<30 \%$ woody cover), shrubland ( $\geq 30 \%$ cover of shrub species such as autumn olive, hawthorn, multiflora rose, and shrubby St. Johnswort [Hypericum prolificum] with scattered trees and an herbaceous understory), young forest (regenerating forest stands generally resulting from timber harvest, dominated by saplings $\leq 10 \mathrm{~cm}$ dbh, displaying distinct edges against surrounding forest, and often dissected by logging roads), open water, road, and structures (Aldinger et al. 2017).

\section{Vermivora Warbler Census}

During April-June 2008-2015, we captured adult male and female Vermivora warblers in mist nets using conspecific song audio lures to aid with our census of territorial male Vermivora warblers. We marked adults with unique combinations of up to three colored leg bands and one USGS aluminum leg band to allow for individual identification by re-sighting with binoculars. We recorded age using plumage characteristics (second year [SY], after second year [ASY], or after hatch year [AHY]; Pyle 1997), phenotype (Golden-winged Warbler, Blue-winged Warbler, Brewster's Warbler hybrid, Lawrence’s Warbler hybrid; Parkes 1951), and sex. We were unable to mark $100 \%$ of territorial males during all years (2008 $=43 \%$ banded, $2009=77 \%, 2010=$ 92\%, $2011=98 \%, 2012=100 \%, 2013=100 \%, 2014=94 \%)$. However, the combination of behavior, plumage, song characteristics, and juxtaposition with other marked males served as identification for unmarked males.

We searched shrubland cover type on each pasture at least every three days during dawn to 1400 EDT during May-June 2008-2014. All shrubland cover type on our pastures was $\leq 200$ m from a point count location established as part of another study (Aldinger and Wood 2015). Therefore, we used these point count locations as a type of spot-mapping grid to ensure that we searched all shrubland cover type (Robbins 1970, Bibby et al. 2000). When we encountered a 
male Vermivora warbler, we determined his identity and recorded up to 30 locations per day with a Garmin global positioning system (GPS) unit accurate to $\pm 5 \mathrm{~m}$ using point averaging. While following a male, we recorded each location only one time regardless of how long the bird remained there (Frantz et al. 2016). We also recorded observations of female Vermivora warblers and evidence of nesting behavior during this time. We watched individual males for behavioral cues that suggested his nesting period was complete to avoid recording locations not representative of his breeding territory (e.g., fledgling feeding, frequent or extended extraterritorial movements, and lack of singing and territorial defense). We considered a male to have a breeding territory when we observed him on $\geq 3$ visits across $\geq 8$ visits to a pasture or confirmed nesting in a specific location (Robbins 1970, Bibby et al. 2000). Including territory mapping, nest searching, and point counts, we made $\geq 8$ visits to all pastures each year (mean $\pm \mathrm{SE}=20 \pm 1$ visits per site per year, median $=19$ visits, range $=8-39$ visits). We used $95 \%$ of the GPS locations for each male to delineate minimum convex polygon (MCP) territories using function mcp in package adehabitatHR (version 0.4.15, Calenge 2006) in program $\mathrm{R}$ (version 3.4.4, $\mathrm{R}$ Development Core Team 2018). We also calculated adult annual return rate for each pasture as $R_{t+1}=N_{t+1} / N_{t}$, where $R_{t+1}$ is return rate for year $t+1, N_{t}$ is the number of territorial banded birds marked on the pasture at time $t$, and $N_{t+1}$ is the number of territorial banded birds marked at time $t$ that established a territory on the same pasture at time $t+1$. Thus, we were unable to calculate return rate for the first year of monitoring for each pasture. To fill these missing data, we assigned the weighted mean annual return rate for that pasture. We weighted the average by the reciprocal of the number of years from time $t$ so that return rates nearer to time $t$ would receive a higher weight, which assumed that temporally nearer values were more representative of this missing value than temporally distant values (Tobler 1970).

\section{Nest Searching and Monitoring}

We located Golden-winged Warbler nests during May-June 2008-2014 using methods outlined in Martin and Geupel (1993), including searching for nests as soon as males established territories, following parental cues to locate nests, and using sticks to part vegetation when checking nests. To reduce the potential bias of discovering a disproportionate number of nests in open vegetation types, we followed behavioral cues of adults such as nest material or food carries, female tzip calls (Ficken and Ficken 1968), male muted song (Highsmith 1989), and inconspicuous movements to areas with nesting cover to discover nests. Golden-winged 
Warblers nest on the ground generally along edges between dense woody cover and herbaceous openings, including fencerows, livestock trails, browse lines, and brush-hogged strips on our pastures (Aldinger and Wood 2014). After a nest had been discovered, we traveled along these existing paths and openings during nest monitoring to reduce disturbance to nests and vegetation and to reduce risk of observer-mediated nest depredation (e.g., creating trails to the nest, Martin and Geupel 1993). We monitored the fate of nests every 1-4 days once incubation had started, with frequency of nest checks increasing with nest age to reduce disturbance early in the nesting period when females are prone to abandon nests and to improve accuracy of fate assignment late in the nesting period (Confer et al. 2010). We considered a nest successful if at least one chick fledged. In addition to frequent nest checks near the estimated fledging date, we also used fledgling presence and age, parent presence and behavior such as singing, re-nesting, and food carrying, and nest condition to determine whether a nest succeeded or failed, so as to reduce incorrect assignment of nest fate (Streby and Andersen 2013). Golden-winged Warblers raise one brood per breeding season and may renest multiple times after nest failure (Aldinger et al. 2015b). When each nest attempt was completed, we used point averaging on a Garmin GPS to obtain nest coordinates with GPSreported accuracy of $\pm 3 \mathrm{~m}$.

Golden-winged Warblers occurred at relatively low densities on our pastures compared to other parts of the species' breeding distribution (Frantz et al. 2016, Aldinger et al. 2017), making each individual nest a critical datum for precision of nest daily survival rate (DSR) estimates. One way to increase precision of estimates from nest placement and survival analyses would be to include nests where a Golden-winged Warbler was socially paired with a Brewster's Warbler hybrid or Blue-winged Warbler. Due to extensive similarities among Vermivora warblers (Patton et al. 2010, Toews et al. 2016, Moulton et al. 2017), we believed that these nests would be sufficiently similar with regards to nest placement and survival to increase precision through a larger sample size. Therefore, our sample included nests with two phenotypic Golden-winged Warbler parents $(\mathrm{n}=125)$ and nests with a phenotypic Golden-winged Warbler paired with a phenotypic Blue-winged Warbler $(\mathrm{n}=3$ ) or phenotypic Brewster's Warbler hybrid ( $\mathrm{n}=15)$.

\section{Field Vegetation Data}

During June-September 2008-2014, we measured grass, blackberry (Rubus spp.), and shrub cover within an 11.3-m radius plot centered on nests and permanent vegetation plots on 
each pasture. By June on our sites, these vegetation classes had reached full leaf development overall, although phenology varied among grass species so that individual species were dominant at different times. We randomly distributed permanent vegetation plot locations $\geq 250 \mathrm{~m}$ apart within shrubland cover type on each pasture. We measured percent grass, Rubus, and shrub cover using four 11.3-m line-point intercept transects radiating from plot center in each cardinal direction (James and Shugart 1970). Each line-point intercept transect had 5 evenly-spaced points with no point at plot center ( $\mathrm{n}=20$ total points per plot). At each point, observers recorded whether shrubs intersected ocular tube crosshairs when viewing through the ocular tube straight towards the ground and straight up. We divided the number of shrub presence points by the total number of points $(n=20)$ for a single estimate of shrub cover per plot. We used the mean value across permanent vegetation plots within a pasture each year to derive annual pasture-specific cover values.

\section{Data Analysis \\ Nest placement}

We measured distance from each nest to mechanical vegetation management as an index of Golden-winged Warbler behavioral response to management over time. Mechanical vegetation management occurred in existing shrubland cover type and was designed to maintain rather than create new shrubland cover type. Therefore, we expected only a short-term response wherein Golden-winged Warblers would shift nest placement away from mechanical vegetation management for 1-2 breeding seasons post-management then resume random nest placement relative to mechanical vegetation management. We used the Near tool in ArcMap for Desktop (version 10.4.1, ESRI 2015) to measure the distance from each nest to the nearest polygon shapefile representing shrubland cover type that was treated with mechanical vegetation management. For nests that occurred within a mechanical vegetation management polygon, we assigned a negative distance value representing the distance from the nearest edge of the polygon. We excluded nests from the control pasture since no mechanical vegetation management occurred during our study. Inspection of histogram and quantile-quantile plots indicated that the distribution of distances was positively skewed (minimum $=-76 \mathrm{~m}$, $1^{\text {st }}$ quartile $=-26 \mathrm{~m}$, median $=-13 \mathrm{~m}$, mean $=8 \mathrm{~m}$, $3^{\text {rd }}$ quartile $=4$, maximum $\left.=377 \mathrm{~m}\right)$. Therefore, we used the independence_test function from the coin package (version 1.2-2, Hothorn et al. 2006) in program R (version 3.4.4, R Development Core Team 2018) to perform a permutation test of 
independence ( $n=100,000$ permutations) following a one-way analysis of variance (ANOVA) with blocks design. We specified distance from nest to mechanical vegetation management as a continuous dependent variable and years since mechanical vegetation management as an ordered-factor independent variable. We also used the oneway_test function from the coin package (version 1.2-2, Hothorn et al. 2006) in program R (version 3.4.4, R Development Core Team 2018) to perform a two-sample Fisher-Pitman permutation test ( $\mathrm{n}=100,000$ permutations) comparing pre- and post-treatment nest placement. For both tests, we included pasture as a blocking variable. We considered results statistically significant at $a=0.05$.

\section{Nest survival}

Our first step in nest survival analysis was to compare DSR of nests with two phenotypic Golden-winged Warbler parents to nests with one phenotypic Golden-winged Warbler parent. We predicted that such nests would be subject to the same mechanisms driving DSR as nests with two Golden-winged Warbler parents because of the extensive similarities among Vermivora warblers (Patton et al. 2010, Toews et al. 2016, Moulton et al. 2017). We tested this prediction empirically using the nest survival model of package RMark (version 2.2.4, Laake 2013) in program R (version 3.4.4, R Development Core Team 2018), which is an interface to program MARK (version 9.0, White and Burnham 1999). We formulated a model where DSR varied as a function of a categorical covariate with two levels: two Golden-winged Warbler parents versus one Golden-winged Warbler parent. If the beta coefficient $(\beta)$ 95\% confidence interval (CI) from this model overlapped zero, then we would consider DSR to be statistically similar among all nests. All nests would then be pooled in further analyses.

We developed a priori candidate models of Golden-winged Warbler nest DSR ( $\mathrm{n}=78$ models) considering four sources of model variation: land cover $(n=10)$, management regime $(n$ =17), spatial location $(n=5)$, and time $(n=3)$ covariates (Table 1). We measured land cover, management regime, and spatial location covariates at the nest location ("nest scale”), within the 95\% MCP of the nest's social father ("territory scale”), and within the pasture boundary ("pasture scale”). For territories with nests, we collected $32 \pm 2$ (mean \pm SE) GPS locations (range $=1-181$ ) to build 95\% MCPs. One male with a single GPS location disappeared after his nest failed. Therefore, we created a territory by buffering the nest location using the mean size of territories with nests $(1.5 \pm 0.2 \mathrm{ha})$. 
Land cover covariates at the nest scale included vegetation cover type (shrubland or forest), proportion of grass, Rubus, and shrub cover measured at 11.3-m vegetation plots, and distance to forest edge (positive for nests in shrubland cover type, negative for nests in forest cover type), at the territory scale included proportions of herbaceous, forest, and shrubland cover types within the territory, and at the pasture scale included amounts of herbaceous and shrubland cover types within the pasture. We placed more emphasis on coarser-scale land cover covariates for DSR models because cover type has been more definitively linked to Golden-winged Warbler nest DSR (Confer et al. 2010, Streby et al. 2014, Peterson et al. 2016) than fine-scale field-collected vegetation data, which have generally been weakly or tentatively linked to DSR (Bulluck and Buehler 2008, Aldinger et al. 2015b, McNeil et al. 2017). Specifically, shrubland and forest cover types were negatively and positively associated with DSR for Golden-winged Warblers, respectively (Streby et al. 2014). We included herbaceous cover type as a covariate in DSR models because of increased predation rates associated with field-forest ecotones (Gates and Gysel 1978) and evidence of both positive and negative associations between grass cover and Golden-winged Warbler nest DSR (Aldinger et al. 2015b, Peterson et al. 2016).

Management regime covariates at the nest scale included management type (GM, Gm, gM, or gm) and at the territory and pasture scales included proportions of management types (GM, Gm, gM, GMm, GgM, gMm, Ggm, and gm; Table 1). Because management types at the territory and pasture scales were not mutually exclusive, we did not include covariates for more than one management type in a single model. We also included an interaction with years since management in some models with amount of mechanical vegetation management (i.e., GM, gM, and GgM) because the association between DSR and management may change over time (Saab et al. 2007, Tozer et al. 2012). We include covariates representing management regime because a prevalent theme in modern Golden-winged Warbler research has been evaluating variation in demographic rates among different management regimes or the vegetation characteristics resulting from specific types of management (Kubel and Yahner 2008, Aldinger and Wood 2014, Aldinger et al. 2015b, McNeil et al. 2017, Streby et al. 2018). In Pennsylvania, Golden-winged Warblers had higher nest survival in clearcuts compared to utility rights-of-way (Kubel and Yahner 2008). The authors hypothesized that vegetation structure varied by management regime, resulting in different predator movements such that predators generally traveled nearer to nests in the right-of-way than they did in the clearcut. Similarly, we hypothesized that grazing and 
mechanical vegetation management could potentially influence depredation rates by changing structure and consequently predator movements along edges where Golden-winged Warblers often nest (Aldinger and Wood 2014).

Spatial location covariates included pasture, study area, and elevation (Table 1). Time covariates included time within season (linear and quadratic), year, and years since management. Elevation was the only spatial location or time covariate that was scale-variant. We used minimum elevation for the territory and pasture scales (Aldinger et al. 2017). We included models of spatial location and time in part because these potentially important sources of variation in DSR can substantially influence study conclusions if not appropriately considered in study design or analysis (Mahon and Martin 2006). For example, multiple studies have documented annual fluctuations in food resources resulting in increased predator populations and consequently decreased nest survival (Mahon and Martin 2006, Schmidt et al. 2008), including for Golden-winged Warblers (Kubel and Yahner 2008). As such, strong variation in DSR resulting from pulsed resources could be incorrectly attributed to other variables of interest. Explicitly modeling variation in DSR by year or time of season can help to detect and explain such phenomena, and long-term studies like ours ( $n=7$ years) also increase the likelihood of drawing accurate conclusions despite annual variation in DSR. Finally, we included covariates for study area and pasture, as well as other previously described pasture-scale covariates, to derive pasture-scale DSR estimates to include in our next analysis modeling population trends over time. As a key component of seasonal productivity, nest survival may be associated with songbird population trends overall and therefore is important to include among competing hypotheses about population trends (Schmidt 2003).

We evaluated competing models of DSR of Golden-winged Warbler nests using the nest survival model of package RMark (version 2.2.4, Laake 2013) in program $\mathrm{R}$ (version 3.4.4, $\mathrm{R}$ Development Core Team 2018). We included nests that reached at least the egg-laying stage in analyses. We modeled the binomially distributed data with the user-defined, logit-link function while simultaneously considering associations with land cover, management regime, spatial, and temporal covariates. For all covariates with continuous values, we included a model with a linear and a quadratic term because Golden-winged Warbler nest DSR may exhibit curvilinear associations with covariates (Aldinger et al. 2015b). We did not standardize individual covariates, because the unstandardized covariates did not affect numerical optimization 
(Dinsmore et al. 2002, Rotella 2007). We used Akaike’s Information Criterion adjusted for small sample size $\left(\mathrm{AIC}_{\mathrm{c}}\right.$ ) to select among competing models (Burnham and Anderson 2002). We considered the model with the lowest $\mathrm{AIC}_{\mathrm{c}}$ value to be the best-supported model given the data and any models with $\Delta \mathrm{AIC}_{\mathrm{c}} \leq 2.0$ were considered plausible (Burnham and Anderson 2002). We compared Akaike weights $\left(w_{\mathrm{i}}\right)$ to assess the relative plausibility of each model in our set of candidate models. For plausible models, we considered results to be biologically important if the beta coefficient 95\% CI did not overlap zero.

\section{Population trends}

Our final objective was to model male Golden-winged Warbler density over time, derived from our annual Vermivora warbler census, as a function of covariates hypothesized to be associated with Golden-winged Warbler density specifically and as a function of covariates documented to be associated with population trends of migratory songbirds in general. We considered five sources of model variation: land cover $(n=9)$, management regime $(n=8)$, spatial location $(n=5)$, time $(n=1)$, and Vermivora demographic $(n=12)$ covariates (Table 2$)$. We measured sources of model variation at the scales of each pasture, study area, 1.5-km pasture buffer, and 5-km pasture buffer. The 1.5-km and 5-km buffer distances were based on observed within-season movements and between-season dispersal of Vermivora warblers on our study areas, respectively (Frantz et al. 2016, dissertation Chapter 3). Land cover covariates at the pasture scale included shrub cover from vegetation plots and amounts of herbaceous and shrubland cover types and at the 1.5-km and 5-km scales included proportions of forest, herbaceous, and shrubland cover types. Proportions of forest and shrubland cover types are associated with Golden-winged Warbler density at multiple spatial scales (Thogmartin 2010, Bakermans et al. 2015a, Crawford et al. 2016, Aldinger et al. 2017). Synthesis of these studies suggests that Golden-winged Warblers are found in landscapes (range 1.5-16-km radius) with $>60 \%$ forest cover type and that within these heavily forested landscapes, their density is positively associated with shrubland cover type. Because our study occurred in a heavily forested landscape, we expected Golden-winged Warbler population trend to be positively associated with proportion of shrubland cover type.

Management regime covariates at the pasture scale included proportions of management types (GM, Gm, gM, GMm, GgM, gMm, Ggm, and gm). Golden-winged Warbler response to management varies predictably with vegetative succession with a peak in density 16-20 years 
after cessation of management (Chapter 5). Therefore, we expected that grazing and mechanical vegetation management intended to maintain the current successional state would result in stable populations of Golden-winged Warblers over time. However, this assumes that breeding habitat is a primary limiting factor for Golden-winged Warbler populations, which recent evidence suggests may not be the case (Kramer et al. 2018).

Spatial location covariates included pasture, study area, and minimum elevation, the last of which we measured at the pasture, $1.5-\mathrm{km}$, and $5-\mathrm{km}$ scales. We expected lower rates of population decrease where Golden-winged Warbler density peaks at minimum elevation of 804 $\mathrm{m}$ within 1.5-5 km (Aldinger et al. 2017). Golden-winged Warbler populations may be more stable at these relatively high elevations because of segregation from Blue-winged Warblers, which occur at lower elevations in the Appalachian Mountains region ( $<500 \mathrm{~m}$, Crawford et al. 2016).

Vermivora demographic covariates included male, female, and combined density for Blue-winged Warblers, hybrids, and all non-Golden-winged Warblers combined, proportion of SY Golden-winged Warbler males, Golden-winged Warbler adult male return rate, and Goldenwinged Warbler nest DSR derived from our nest survival analysis. Blue-winged Warbler density is negatively correlated with Golden-winged Warbler density with the former generally replacing the latter within 50 years of initial contact (Gill 1980), with few exceptions (Confer et al. 1998). The mechanism behind Blue-winged Warblers replacing Golden-winged Warblers is still not known (Gill 2004, Confer 2006), but potential explanations have included variation among species in plasticity of habitat use (Confer and Knapp 1981), genetic introgression (Gill 1997), interspecific competition (Will 1986, Confer et al. 2003), extra-pair copulation (Confer and Larkin 1998, Vallender et al. 2007), and survival during migration and non-breeding periods (Kramer et al. 2018). Age ratio may be associated with habitat quality such that older males comprise a larger proportion of the population in high-quality habitats (Hunt 1996). Thus, populations with a higher proportion of older males might be expected to be stable or increase due to increased reproductive output or immigration (Reitsma et al. 2008, Haché and Villard 2010). Finally, nest survival and return rate are indices of birth and death which ultimately regulate population size along with immigration and emigration (Cohen 1969, Donovan and Thompson 2001, Schmidt 2003). For Golden-winged Warblers, the relative importance of different vital rates throughout the annual cycle have only recently started to come to light, so the 
relative performance of these two covariates specifically will add valuable information to research on population regulation for this species (Kramer et al. 2018).

We used package Ime4 (version 1.1-16, Bates et al. 2015) in program R (version 3.4.4, R Development Core Team) to formulate Poisson lognormal mixed effect models of Goldenwinged Warbler density fitted with Laplace estimation. Because our objective was to evaluate variation in population trends over time, each model included one linear covariate term and an interaction with years since management. We used years since management rather than calendar year because management occurred during different calendar years among our two study areas. This model structure also helped to avoid overfitting based on our relatively small sample size of pastures ( $n=6$ pastures, $n=38$ pasture-years). The constant density model (intercept only) and a model with only years since management did not include this interaction. We included a random intercept for pasture to account for density measured on the same pastures across years and a random slope for years since management to allow density to trend differently among pastures over time. Each model included an offset for the log of the amount of shrubland cover type per pasture to convert abundance to density (i.e., males per ha of shrubland cover type). We used Akaike's Information Criterion adjusted for small sample size ( $\mathrm{AIC}_{\mathrm{c}}$ ) to select among competing models (Burnham and Anderson 2002). We considered the model with the lowest $\mathrm{AIC}_{\mathrm{c}}$ value to be the best-supported model given the data and any models with $\Delta \mathrm{AIC}_{\mathrm{c}} \leq 2.0$ were considered plausible (Burnham and Anderson 2002). We compared $w_{\mathrm{i}}$ to assess the relative plausibility of each model in our set of candidate models. For plausible models, we considered results to be biologically important if the beta coefficient 95\% CI did not overlap zero. We model-averaged across plausible models $\left(\Delta \mathrm{AIC}_{\mathrm{c}} \leq 2.0\right)$ to derive predicted values of DSR for individual covariates from DSR models.

\section{RESULTS}

\section{Nest Placement}

During 2008-2014, we discovered 125 nests where both parents were Golden-winged Warblers and 18 nests with one Golden-winged Warbler parent for a total of 143 nests. We discovered 7-33 nests per year and 12-49 nests per pasture across years combined. We discovered $68 \%$ of nests $(n=97)$ during building, $7 \%(n=10)$ during egg-laying, $14 \%(n=20)$ 
during incubation, and $11 \%(\mathrm{n}=16)$ during the nestling stage. Eighty-six percent of nests $(\mathrm{n}=$ 123) were active at least to the egg-laying stage.

After excluding nests from the control pasture $(n=19)$, we had 109 nests with two Golden-winged Warbler parents and 15 nests with one Golden-winged Warbler parent for analysis of nest placement relative to mechanical vegetation management. Nest distance to mechanical vegetation management did not vary as a function of years since management (Permutation Test of Independence, $Z=0.45, P=0.66$ ) or pre- versus post-management (Twosample Fisher-Pitman Permutation Test, $Z=1.17, P=0.25)$. Mean \pm SE distance to mechanical vegetation management across all nests was $8 \pm 7 \mathrm{~m}$. These results suggest that Golden-winged Warblers did not change nest placement behavior because of mechanical vegetation management.

\section{Nest Survival}

After excluding nests that did not reach at least the egg-laying stage $(\mathrm{n}=20)$, we had 123 nests for analysis of nest survival. Nest monitoring occurred over a 52-day period across years (earliestegg observed 7 May, latest fledging observed 27 June, latest active nest found failed 28 June). Of nests that reached at least egg-laying, 51\% $(n=63)$ fledged at least one chick and were considered successful. Eight-eight percent of nest failures $(n=53)$ were attributed to depredation. Only $2 \%$ of nests $(n=2)$ were parasitized by Brown-headed Cowbirds. Each parasitized nest successfully fledged the host chicks and a single cowbird chick. No nest failures were attributed to trampling or depredation by livestock.

Nest DSR was statistically similar among nests with two Golden-winged Warbler parents $\left(\beta_{\text {intercept }}=3.28,95 \% \mathrm{CI}=3.01-3.55 ; \mathrm{DSR}=0.964,95 \% \mathrm{CI}=0.953-0.972\right)$ and nests with one Golden-winged Warbler parent $(\beta=0.39$, 95\% CI $=-0.47-1.24$; DSR $=0.975$, 95\% CI $=0.946-$ 0.988) because the $\beta$ 95\% CI overlapped zero. Therefore, we pooled all nests for further analysis of DSR.

Among candidate models of DSR, 13 models had $\triangle \mathrm{AIC}_{\mathrm{c}} \leq 2.0$ and were considered plausible (Table 3; Burnham and Anderson 2002). Nest DSR was higher on pastures in Pocahontas County $($ mean $=0.973,95 \% \mathrm{CI}=0.962-0.981)$ than on pastures in Randolph County (mean $=0.949,95 \%$ CI $=0.926-0.965)$. It also was positively associated with amount of pasturescale shrubland cover type, proportion of territory-scale grazed (GMm) shrubland cover type, and nest- and territory-scale elevation, and negatively associated with proportions of territory- 
scale ungrazed and unmanaged (gm), unmanaged (Ggm), and ungrazed (gMm) shrubland cover types (Table 4, Figure 3). We model-averaged DSR across plausible models that included pasture and study area scale covariates to derive annual pasture-scale estimates of DSR for use in our population trend analysis.

\section{Population Trends}

During our annual Vermivora census, we observed steep decreases in male Goldenwinged Warbler density on our 3 pastures in Randolph County. At the beginning of our study in 2008, we mapped territories of 27 Golden-winged Warbler males and 1 Brewster's Warbler male. By the conclusion of our study 6 years later in 2014, only 2 territorial male Golden-winged Warblers remained and 1-4 Blue-winged Warbler males occupied the pastures each year during 2010-2014. Across the three pastures in Pocahontas County monitored concurrently during 2010-2014, we observed annual fluctuations in both directions, with 21 male Golden-winged Warblers in 2010, a peak of 26 males in 2012, and a low of 12 males in 2014. We observed 2-4 Brewster’s Warbler males annually and never observed Blue-winged Warbler males.

The only plausible model $\left(\Delta \mathrm{AIC}_{\mathrm{c}} \leq 2.0\right.$, Burnham and Anderson 2002) of Golden-winged Warbler density included an interaction between pasture-scale nest DSR and years since management (Table 5). Based on model weight $\left(w_{i}=0.53\right)$, this model was over 5 times more plausible than the next best-supported model that included an interaction between 1.5-km minimum elevation and years since management $\left(\Delta \mathrm{AIC}_{\mathrm{c}}=3.39, w_{i}=0.10\right)$. Overall Goldenwinged Warbler density decreased by $28 \%$ per year, which is a steeper decrease than any currently reported by the North American Breeding Bird Survey (Sauer et al. 2017), and there was a biologically important interaction between nest DSR and years since management in predicting density (Table 6). The interaction suggested that the rate of population decrease was lessened at higher values for nest DSR. For example, at our minimum value for nest DSR (0.934), Golden-winged Warbler density decreased by 50\% per year, while at our maximum value for nest DSR (0.978), Golden-winged Warbler density decreased by only 1\% per year (Figure 4).

\section{DISCUSSION}

Competing hypotheses attempting to explain Golden-winged Warbler population trends have had varying levels of empirical backing, with no explanation garnering overwhelming 
support (Rohrbaugh et al. 2016, Rosenberg et al. 2016). Perhaps the most compelling evidence to date recently suggested that limiting factors during the non-breeding season may be driving population trends observed during the breeding season (Kramer et al. 2018). Overall though, efforts to identify population-regulating mechanisms and their relative contributions to population trends may have been hampered by the common use of cross-sectional rather than longitudinal study designs and analyses (but see Gill 1980, 1987; Bulluck et al. 2013; Streby et al. 2018). In this study, we demonstrated that local Golden-winged Warbler population trends across 5-7 years were associated with pasture-scale nest survival more convincingly than any other competing hypothesis we considered. Furthermore, nest survival itself was higher in actively-managed shrublands and management designed to maintain shrubland cover type did not change nest placement for Golden-winged Warblers. We present evidence that managing for high nest survival (nest DSR $\geq 0.978$ ) may help to offset mortality during the non-breeding season and result in stable breeding population trends. This finding is important because individual warblers across our pastures presumably use similar migratory routes and wintering grounds and are therefore subject to similar limiting factors during the non-breeding season (Kramer et al. 2018). Our results will help to justify, inform, and adapt state and regional Golden-winged Warbler conservation efforts such as the Working Lands for Wildlife partnership (U.S. Natural Resources Conservation Service 2012).

Our study was the first to link Golden-winged Warbler nest survival with observed population trends in the Appalachian Mountains region. This result is not entirely unexpected since nest survival is necessarily an important part of Golden-winged Warbler full season productivity, which is a component of population growth rate (Cohen 1969, Peterson et al. 2016, Streby et al. 2018). Furthermore, nest survival has sometimes been documented as a primary limiting factor for populations of migratory birds (Donovan and Thompson 2001, Schmidt 2003, Mahon and Martin 2006, Schmidt et al. 2008). In Illinois for example, populations of multiple species of ground- and shrub-nesting songbirds decreased across a broad geographic extent for 20 years because of nest depredation from growing raccoon (Procyon lotor) populations (Schmidt 2003). The noteworthy implication from our results then is not simply that nest survival was associated with population trend, but that local populations potentially may be sustained by managing for high-quality nesting habitat despite presumed high mortality during the non-breeding season (Kramer et al. 2018). Managing for high-quality nesting habitat in the 
Appalachian Mountains region as a primary action may not be an optimal conservation strategy for the migratory Golden-winged Warbler (Martin et al. 2007). However, it may be the most pragmatic strategy for the time being because of existing conservation activities (e.g., U.S. Natural Resources Conservation Service 2012) that could grant additional time for this imperiled species until targeted conservation efforts are underway in their poorly-understood, geographically- and politically-distant non-breeding habitats (Wilcove and Wikelski 2008, Rohrbaugh et al. 2016).

So how do we manage for high-quality nesting habitat? Multiple studies of Goldenwinged Warbler nest survival have yielded only tentative associations with carefully-measured vegetation characteristics (Bulluck and Buehler 2008, Aldinger et al. 2015b, McNeil et al. 2017). Similarly, our nest DSR models using vegetation characteristics measured within a 11.3-m plot were not plausible. Other studies have had more success evaluating Golden-winged Warbler reproductive rates using variables derived from coarse-scale land cover types (Confer et al. 2010, Streby et al. 2014, Peterson et al. 2016). Streby et al. (2014) found higher nest and lower fledgling survival in shrubland compared to forest cover type, implying that nest survival is negatively correlated with vegetation successional stage. Our plausible nest DSR models that included covariates based on coarse-scale land cover (6 out of 13 plausible models) similarly suggested that Golden-winged Warbler nest DSR was positively associated with shrubland successional stage and pasture-scale shrubland patch size. While the underlying reason for higher nest survival in these earlier (i.e., recently or continually managed) shrubland stages remains unclear, our results are consistent with other published studies of Golden-winged Warbler nesting and are reasonable when considering the Golden-winged Warbler's preference for relatively early stages of shrublands and young forest (Confer and Knapp 1981, Streby et al. 2014). As for patch size, shrubland-nesting birds including the closely-related Blue-winged Warbler tend to not display the strong area sensitivity of grassland- and forest-nesting birds, with one of the few consistent findings being that shrubland patches must be at least as large as the size of a breeding territory (King and DeGraaf 2004, Askins et al. 2007, Chandler et al. 2009). Therefore, our evidence of area sensitivity with regards to nest survival is somewhat unique among shrubland-nesting birds.

Four of the 6 plausible nest DSR models using coarse-scale land cover covariates were related to how shrubland cover type was managed. The general conclusion from these models 
was that Golden-winged Warbler nest survival was positively associated with the amount of grazed and mechanically managed shrubland cover type at the territory scale, but not at the nest or pasture scale. A previous study on some of these pastures similarly found that nest survival was not associated with the presence of livestock grazing at the nest scale (Aldinger and Wood 2014). Most other studies of avian nest survival on managed pastures have occurred in grasslands and in mid-western and western North America and therefore may have limited applicability to shrublands in the Appalachian Mountains (Bock et al. 1993, Fondell and Ball 2004, Harrison et al. 2011). Grazing effects in these studies varied among vegetation communities and among avian species depending on their life-histories, but generally birds that were more dependent on herbaceous ground cover for nesting and foraging were more vulnerable to direct negative grazing effects (Bock et al. 1993). Because nest failures in our study were not directly attributed to livestock depredation or trampling, mechanical vegetation management, or cowbird brood parasitism, nest survival likely was linked to variation in predator behavior or abundance as a result of management-related differences in vegetation characteristics. Among possible explanations, we hypothesize that grazing and mechanical vegetation management on our pastures, which were intended to break up homogeneous thickets of shrubs, reduced the prevalence of abrupt edge characteristics used by predators for activities such as thermoregulation (Blouin-Demers and Weatherhead 2001) and travel (Fenske-Crawford and Niemi 1997). To better understand the mechanisms behind variation in nest survival and the consequences of management actions, a study of Golden-winged Warbler nests where nest predator species are identified with certainty is needed.

The remaining biologically important, plausible nest DSR models included covariates for elevation and study area, which may relate to variation in predator communities and behavior. Golden-winged Warbler nest predator communities remain unstudied and their quantification could significantly improve conservation efforts. However, anecdotal evidence from studies of Golden-winged Warblers and empirical data from studies of other ground-nesting birds suggest that small mammals and snakes are the primary nest predators (Kubel and Yahner 2008, Sperry et al. 2008, Confer et al. 2010, Bulluck et al. 2013, Streby et al. 2014). Snake depredation of Golden-winged Warbler fledglings may be more prevalent in the southern Appalachian Mountains in Tennessee (52\% of depredation, Lehman 2017) compared to more northern study areas in Pennsylvania (0\%, J. Larkin et al., unpublished data) and Minnesota (9\%, Streby et al. 
2016a). Therefore, we infer that the positive relationship between elevation and nest DSR may relate to temperature-dependent variation in abundance and activity of snakes (Sperry et al. 2008). Maximum daily temperatures during May-June 2003-2015 were $1.7 \pm 0.1^{\circ} \mathrm{C}$ warmer at a $866 \mathrm{~m}$ elevation weather station (range $16.3-25.0^{\circ} \mathrm{C}$, ID $=$ USC00463464, coordinates $=$ $38.8072,-79.7172$ ) compared to a $1132 \mathrm{~m}$ elevation station (range $14.5-23.4^{\circ} \mathrm{C}, \mathrm{ID}=$ USC00462211, coordinates $=39.098,-79.4322$; Diamond et al. 2013). Both stations were $<30$ $\mathrm{km}$ from our northern study area and corresponded to our minimum (830 m) and maximum (1175 m) nest elevations. Eastern rat snake (Pantherophis alleghaniensis) spring emergence occurs primarily when maximum daily temperature is $10-25^{\circ} \mathrm{C}$, number of snakes emerging is positively correlated with temperature, and preferred body temperature is $28.1^{\circ} \mathrm{C}$ (BlouinDemers et al. 2000, Blouin-Demers and Weatherhead 2001). Thus, the May-June temperatures on our pastures may correspond with important temperature thresholds for snakes, suggesting that even modest elevational temperature variation during the nesting period may influence snake abundance and activity enough to cause a measurable difference in Golden-winged Warbler nest DSR. To answer our question posed at the beginning of these three paragraphs on nest survival, our results suggest that using cattle grazing and mechanical cutting to actively maintain large shrubland patches (maximum patch size $=88$ ha) with $30-60 \%$ shrub cover at high elevations (maximum nest elevation $=1175 \mathrm{~m})$ may maximize nest survival (Golden-winged Warbler Working Group 2013).

We note that there are limitations to our results, namely the nonrandom selection and small sample size of pastures. For a species as rare as the Golden-winged Warbler in West Virginia (Sauer et al. 2017), a randomized design simply was not feasible. Still, pastures like the ones we monitored with low-intensity grazing are relatively common on private land within the Golden-winged Warbler's range in West Virginia (Aldinger and Wood 2014, U.S. National Agricultural Statistics Service 2017). Furthermore, these types of shrublands (44\% occupancy rate, $n=63$ ) may be preferred by Golden-winged Warblers over young forests resulting from timber harvest in West Virginia ( $0 \%$ occupancy rate, $n=13$; Aldinger et al. 2017). Thus, we believe that these pastures do reflect the larger population of vegetation communities used by Golden-winged Warblers in West Virginia and perhaps other similar locations like Tennessee and North Carolina (Terhune et al. 2016). We also believe that the duration and intensity with which we monitored each pasture lends precision and credibility to our results. While the rarity 
of Golden-winged Warblers in West Virginia limited sample size, it enabled us to measure many variables with the detail of a census.

Incorporating additional study areas or replicating our analytical approach throughout the Appalachian Mountains region, such as existing monitoring efforts in Pennsylvania, Tennessee, and North Carolina, could increase confidence in and applicability of results (Aldinger et al. 2015a). Taking a regional approach has been identified as an important research need for Golden-winged Warblers (Streby et al. 2016b) and will enhance conservation efforts because the species’ breeding ecology and population limiting factors vary across space such that sitespecific conservation plans may be required (Terhune et al. 2016, Rohrbaugh et al. 2016). Variation in fledgling survival and nest predator communities are two additional variables that we were unable to include in our study but are likely to be associated with Golden-winged Warbler population trends in some areas and would therefore enhance further analyses if data are available or could be collected (Streby et al. 2016a, Lehman 2017).

We conclude by highlighting that the complex life histories of migratory species make it likely that multiple factors such as nest survival and adult winter survival act together to drive population trends (Holmes 2007, Kramer et al. 2018). Furthermore, it is possible that conditions experienced during one stage of a migratory bird's life cycle could affect demographic rates during subsequent stages (Norris et al. 2004). As such, studies focusing on a single stage of the life cycle may not be able to disentangle whether observed limiting factors are the result of conditions during the current stage or carry-over effects from a previous stage. A major strength of our study then is that we observed variation in population trends and identified a limiting factor across a small geographic area during the breeding season, meaning that non-breeding season conditions experienced among local populations likely were relatively consistent (Kramer et al. 2018). Our results can be used to update regional guidelines for ongoing conservation efforts (U.S. Natural Resources Conservation Service 2012, Golden-winged Warbler Working Group 2013). If these conservation efforts focus on promoting high-quality nesting habitat by managing large patches of shrubland cover type at the upper range of elevations known to be occupied by Golden-winged Warblers, local populations may be stabilized until full life-cycle conservation strategies can be implemented.

\section{ACKNOWLEDGMENTS}


The Littlefield family, West Virginia Cooperative Fish and Wildlife Research Unit, and West Virginia Division of Natural Resources Elkins Operation Center provided housing. The U.S. Forest Service Monongahela National Forest allowed access to study sites. We thank J. Aldinger, I. Batterman, P. Bryant, A. Dalton, M. Frantz, C. Fitzmorris, N. Glover, J. Kreiser, C. Lauzau, K. Loucks, S. Malinich, A. Newman, V. Olmstead, K. Pratt, M. Roach, C. Roy, J. Saborse, C. Sedgwick, L. Smith, L. Stout, D. Ware, and M. Weston for long hours of work in the field. J. Anderson, G. Merovich, M. Strager, R. Tallman, and members of the Golden-winged Warbler Working Group provided valuable insight during this research. L. A. Nolan assisted with delineation of Golden-winged Warbler minimum convex polygons. The West Virginia Division of Natural Resources Wildlife Diversity Program (013555.2.1000502W), U.S. Fish and Wildlife Service Migratory Bird Program (F12AP00643), U.S. Forest Service Monongahela National Forest (12-PA-11092100-020), U.S. Natural Resources Conservation Service (68-748212-502), and the National Fish and Wildlife Foundation (10012877.1.1004706R) granted funding for this research. Co-author C.M.J. is affiliated with the U.S. Forest Service Monongahela National Forest, one of the funding sources. None of the funders required approval of the manuscript before submission or publication. Any use of trade, firm, or product names is for descriptive purposes only and does not imply endorsement by the U.S. Government. This study was completed under the auspices of West Virginia University Institutional Animal Care and Use Committee protocols 07-0303 and 10-0201.

\section{LITERATURE CITED}

Afshartous, D., and R. A. Preston. 2011. Key results of interaction models with centering. Journal of Statistics Education 19:3.

Aldinger, K. R., M. H. Bakermans, J. L. Larkin, J. Lehman, D. J. McNeil, A. Tisdale, D. A. Buehler, P. B. Wood, C. G. Smalling, L. Siefferman, T. Fearer. 2015a. Monitoring and evaluating Golden-winged Warbler use of breeding habitat created by Natural Resources Conservation Service practices. Conservation Effects Assessment Program Final Report, USDA Natural Resources Conservation Service.

Aldinger, K. R., T. M. Terhune II, P. B. Wood, D. A. Buehler, M. H. Bakermans, J. L. Confer, D. J. Flaspohler, J. L. Larkin, J. P. Loegering, K. L. Percy, A. M. Roth, and C. G. Smalling. 2015b. Variables associated with nest survival of Golden-winged Warblers (Vermivora chrysoptera) among vegetation communities commonly used for nesting. Avian Conservation and Ecology 10:6. 
Aldinger, K. R., and P. B. Wood. 2014. Reproductive success and habitat characteristics of Golden-winged Warblers in high-elevation pasturelands. Wilson Journal of Ornithology 126:279-287.

Aldinger, K. R., P. B. Wood, and C. M. Johnson. 2017. Refined conservation strategies for Golden-winged Warblers in the West Virginia highlands with implications for the broader avian community. Condor 119:762-786.

Askins, R. A., B. Zuckerberg, and L. Novak. 2007. Do the size and landscape context of forest openings influence the abundance and breeding success of shrubland songbirds in southern New England. Forest Ecology and Management 250:137-147.

Bakermans, M. H., B. W. Smith, B. C. Jones, and J. L. Larkin. 2015a. Stand and within-stand factors influencing Golden-winged Warbler use of regenerating stands in the central Appalachian Mountains. Avian Conservation and Ecology 10:10.

Bakermans, M. H., C. L. Ziegler, and J. L. Larkin. 2015b. American Woodcock and Goldenwinged Warbler abundance and associated vegetation in managed habitats. Northeastern Naturalist 22:690-703.

Bates, D., M. Maechler, B. Bolker, and S. Walker. 2015. Fitting linear mixed-effects models using lme4. Journal of Statistical Software 67:1-48.

Bibby, C. J., N. D. Burgess, D. A. Hill, and S. H. Mustoe 2000. Bird Census Techniques, second edition. Academic Press, London, UK.

Blouin-Demers, G., K. A. Prior, and P. J. Weatherhead. 2000. Patterns of variation in spring emergence by black rat snakes (Elaphe obsoleta obsoleta). Herpetologica 56:175-188.

Blouin-Demers, G., and P. J. Weatherhead. 2001. Thermal ecology of black rat snakes (Elaphe obsoleta) in a thermally challenging environment. Ecology 82:3025-3043.

Bock, C. E., V. A. Saab, T. D. Rich, and D. S. Dobkin. 1993. Effects of livestock grazing on Neotropical migratory landbirds in western North America. In Status and management of Neotropical migratory landbirds (D. M. Finch and P. W. Stangel, Editors), pp. 296-309. U.S. Department of Agriculture, Forest Service, Rocky Mountain Forest and Range Experiment Station, Fort Collins, CO, USA.

Buehler, D. A., A. M. Roth, R. Vallender, T. C. Will, J. L. Confer, R. A. Canterbury, S. B. Swarthout, K. V. Rosenberg, and L. P. Bulluck. Status and conservation priorities of Golden-winged Warbler (Vermivora chrysoptera) in North America. Auk 124:14391445.

Bulluck, L. P., and D. A. Buehler. 2008. Factors influencing Golden-winged Warbler (Vermivora chrysoptera) nest-site selection and nest survival in the Cumberland Mountains of Tennessee. Auk 125:551-559.

Bulluck, L. P., and D. A. Buehler, R. Vallender, and R. J. Robertson. 2013. Demographic comparison of Golden-winged Warbler (Vermivora chrysoptera) populations in northern and southern extremes of their breeding range. Wilson Journal of Ornithology 125:479490.

Burnham, K. P., and D. R. Anderson. 2002. Model selection and multimodel inference: a practical information-theoretic approach, second edition. Springer, New York, NY, USA. 
Calenge, C. 2006. The package adehabitat for the R software: a tool for the analysis of space and habitat use by animals. Ecological Modelling 197: 516-519.

Chandler, R. B., D. I. King, and C. C. Chandler. 2009. Effects of management regime on the abundance and nest survival of shrubland birds in wildlife openings in northern New England, USA. Forest Ecology and Management 258:1669-1676.

Cohen, J. 1969. Natural primate troops and a stochastic population model. American Naturalist 103:455-477.

Confer, J. L., K. W. Barnes, and E. C. Alvey. 2010. Golden- and Blue-winged warblers: distribution, nesting success, and genetic differences in two habitats. Wilson Journal of Ornithology 122:273-278.

Confer, J. L., P. Hartman, and A. Roth. 2011. Golden-winged Warbler (Vermivora chrysoptera). In Birds of North America Online (A. Poole, Editor). Cornell Laboratory of Ornithology, Ithaca, NY, USA. https://birdsna.org/Species-Account/bna/species/gowwar.

Confer, J. L., J. Gebhards, and J. Yrizarry. 1998. Golden-winged and Blue-winged warblers at Sterling Forest: a unique circumstance. Kingbird 48:19-21.

Confer, J. L., and K. Knapp. 1979. The changing proportion of Blue-winged and Golden-winged warblers in Tompkins County and their habitat selection. Kingbird 29:8-14.

Confer, J. L., and K. Knapp. 1981. Golden-winged Warblers and Blue-winged Warblers: the relative success of a habitat specialist and a generalist. Auk 98:108-114.

Confer, J. L., and J. L. Larkin. 1998. Behavioral interactions between Golden-winged and Bluewinged Warblers. Auk 115:209-214.

Confer, J. L., J. L. Larkin, and P. E. Allen. 2003. Effects of vegetation, interspecific competition, and brood parasitism on Golden-winged Warbler (Vermivora chrysoptera) nesting success. Auk 120:138-144.

Crawford, D. L., R. W. Rohrbaugh, A. M. Roth, J. D. Lowe, S. B. Swarthout, and K. V. Rosenberg. 2016. Landscape-scale habitat and climate correlates of breeding Goldenwinged and Blue-winged warblers. In Golden-winged Warbler Ecology, Conservation, and Habitat Management (H. M. Streby, D. E. Andersen, and D. A. Buehler, Editors). Studies in Avian Biology 49:41-66.

Diamond, H. J., T. R. Karl, M. A. Palecki, C. B. Baker, J. E. Bell, R. D. Leeper, D. R. Easterling, J. H. Lawrimore, T. P. Meyers, M. R. Helfert, G. Goodge, and P. W. Thorne. 2013. U.S. Climate Reference Network after one decade of operations: status and assessment. Bulletin of the American Meteorological Society 94:489-498.

Dinsmore, S. J., G. C. White, and F. L. Knopf. 2002. Advanced techniques for modeling avian nest survival. Ecology 83:3476-3488.

Donovan, T. M., and F. R. Thompson III. 2001. Modeling the ecological trap hypothesis: a habitat and demographic analysis for migrant songbirds. Ecological Applications 11:871882.

ESRI. 2015. ArcGIS Desktop: Release 10. Environmental Systems Research Institute, Redlands, CA, USA. 
Fenske-Crawford, T. J., and G. J. Niemi. 1997. Predation of artificial ground nests at two types of edges in a forest-dominated landscape. Condor 99:14-24.

Fondell, T. F., and I. J. Ball. 2004. Density and success of bird nests relative to grazing on western Montana grasslands. Biological Conservation 117:203-213.

Frantz, M. W., K. R. Aldinger, P. B. Wood, J. Duchamp, T. Nuttle, A. Vitz, and J. L. Larkin. 2016. Space and habitat use of breeding Golden-winged Warblers in the central Appalachian Mountains. In Golden-winged Warbler Ecology, Conservation, and Habitat Management (H. M. Streby, D. E. Andersen, and D. A. Buehler, Editors). Studies in Avian Biology 49:81-94.

Gill, F. B. 1980. Historical aspects of hybridization between Blue-winged and Golden-winged warblers. Auk 97:1-18.

Gill, F. B. 1997. Local cytonuclear extinction of the Golden-winged Warbler. Evolution 51:519525.

Gill, F. B. 2004. Blue-winged Warblers (Vermivora pinus) versus Golden-winged Warblers (V. chrysoptera). Auk 121:1014-1018.

Golden-winged Warbler Working Group. 2013. Best management practices for Golden-winged Warbler habitats in the Appalachian Region. http://www.gwwa.org/plan.

Haché, S., and M. A. Villard. 2010. Age-specific response of a migratory bird to an experimental alteration of its habitat. Journal of Animal Ecology 4:897-905.

Hansen, M. C., S. V. Stehman, and P. V. Potapov. 2010. Quantification of global gross forest cover loss. Proceedings of the National Academy of Sciences of the United States of America 107:8650-8655.

Harrison, M. L., N. A. Mahoney, P. Robinson, A. Newbury, and D. J. Green. 2011. Nest-site selection and productivity of Vesper Sparrows breeding in grazed habitats. Journal of Field Ornithology 82:140-149.

Hill, N. P., and J. M. Hagan III. 1991. Population trends of some northeastern North American landbirds: a half-century of data. Wilson Bulletin 103:165-182.

Holmes, R. T. 2007. Understanding population change in migratory songbirds: long-term and experimental studies of Neotropical migrants in breeding and wintering areas. Ibis 149:213.

Hothorn, T., K. Hornik, M. A. van de Wiel, and A. Zeileis. 2006. A lego system for conditional inference. American Statistician 60:257-263.

Hunt, P. D. 1996. Habitat selection by American Redstarts along a successional gradient in northern hardwood forest: evaluation of habitat quality. Auk 113:875-888.

Hunter, W. C., D. A. Buehler, R. A. Canterbury, J. L. Confer, and P. B. Hamel. 2001. Conservation of disturbance-dependent birds in eastern North America. Wildlife Society Bulletin 29:440-455.

King, D. I., and R. M. DeGraaf. 2004. Effects of group-selection opening size on the distribution and reproductive success of an early-successional shrubland bird. Forest Ecology and Management 190:179-185. 
King, D. I., and S. Schlossberg. 2014. Synthesis of the conservation value of the early-succession stage in forests of eastern North America. Forest Ecology and Management 324:186-195.

Kramer, G. R., D. E. Andersen, D. A. Buehler, P. B. Wood, S. M. Peterson, J. A. Lehman, K. R. Aldinger, L. P. Bulluck, S. Harding, J. A. Jones, J. P. Loegering, C. Smalling, R. Vallender, and H. M. Streby. 2018. Population trends in Vermivora warblers are linked to strong migratory connectivity. Proceedings of the National Academy of Sciences of the United States of America DOI: 10.1073/pnas.1718985115.

Kubel, J. E., and R. H. Yahner. 2008. Quality of anthropogenic habitats for Golden-winged Warblers in central Pennsylvania. Wilson Journal of Ornithology 120:801-812.

Laake, J. L. 2013. RMark: An R interface for analysis of capture-recapture data with MARK. AFSC Processed Report 2013-01. Alaska Fisheries Science Center, NOAA, National Marine Fisheries Service, Seattle, WA, USA.

Lehman, J. A. 2017. Survival and habitat selection of Golden-winged Warblers (Vermivora chrysoptera) during nesting and post-fledging periods at North Cumberland Wildlife Management Area, Tennessee. Master's thesis, University of Tennessee, Knoxville, TN, USA.

Mahon, C. L., and K. Martin. 2006. Nest survival of chickadees in managed forests: habitat, predator, and year effects. Journal of Wildlife Management 70:1257-1265.

Martin, T. G., I. Chadés, P. Arcese, P. P. Marra, H. P. Possingham, and D. R. Norris. 2007. Optimal conservation of migratory species. PLoS ONE 2:e751.

Martin, T. E., and G. R. Geupel. 1993. Nest-monitoring plots: methods for locating nests and monitoring success. Journal of Field Ornithology 64:507-519.

McNeil, D. J., K. R. Aldinger, M. H. Bakermans, J. A. Lehman, A. C. Tisdale, J. A. Jones, P. B. Wood, D. A. Buehler, C. G. Smalling, L. Siefferman, J. L. Larkin. 2017. An evaluation and comparison of conservation guidelines for an at-risk migratory songbird. Global Ecology and Conservation 9:90-103.

Moulton, L. L., R. Vallender, C. Artuso, and N. Koper. 2017. The final frontier: early-stage genetic introgression and hybrid habitat use in the northwestern extent of the Goldenwinged Warbler breeding range. Conservation Genetics 18:1481-1487.

Norris, R. D., P. P. Marra, T. K. Keyser, T. W. Sherry, and L. M. Ratcliffe. 2004. Tropical winter habitat limits reproductive success on the temperate breeding grounds in a migratory bird. Proceedings of the Royal Society of London, Series B 271:59-64.

Parkes, K. C. 1951. The genetics of the Golden-winged $\times$ Blue-winged warbler complex. Wilson Bulletin 63:5-15.

Patton, L. L., D. S. Maehr, J. E. Duchamp, S. Fei, J. W. Gassett, and J. L. Larkin. 2010. Do the Golden-winged Warbler and Blue-winged Warbler exhibit species-specific difference in their breeding habitat use? Avian Conservation and Ecology 5:2.

Peterson, S. M., H. M. Streby, and D. E. Andersen. 2016. Spatially explicit models of full-season productivity and implications for landscape management of Golden-winged Warblers in the western Great Lakes Region. In Golden-winged Warbler Ecology, Conservation, and 
Habitat Management (H. M. Streby, D. E. Andersen, and D. A. Buehler, Editors). Studies in Avian Biology 49:141-160.

Pyle, P. 1997. Identification guide to North American birds, part 1: Columbidae to Ploceidae. Slate Creek Press, Bolinas, CA, USA.

R Development Core Team. 2018. R: A language and environment for statistical computing. Version 3.4.4. R Foundation for Statistical Computing. Vienna, Austria. www.rproject.org.

Reitsma, L. R., M. T. Hallworth, and P. M. Benham. 2008. Does age influence territory size, habitat selection, and reproductive success of male Canada Warblers in central New Hampshire? Wilson Journal of Ornithology 120:446-454.

Robbins, C. S. 1970. An international standard for a mapping method in bird census work. International Bird Census Committee. Audubon Field Notes 24:722-726.

Rohrbaugh, R. W., D. A. Buehler, S. B. Swarthout, D. I. King, J. L. Larkin, K. V. Rosenberg, A. M. Roth, R. Vallender, and T. Will. 2016. Conservation perspectives: review of new science and primary threats to Golden-winged Warblers. In Golden-winged Warbler Ecology, Conservation, and Habitat Management (H. M. Streby, D. E. Andersen, and D. A. Buehler, Editors). Studies in Avian Biology 49:207-215.

Rosenberg, K. V., T. Will, D. A. Buehler, S. B. Swarthout, W. E. Thogmartin, R. E. Bennett, and R. B. Chandler. 2016. Dynamic distributions and population declines of Golden-winged Warblers. In Golden-winged Warbler Ecology, Conservation, and Habitat Management (H. M. Streby, D. E. Andersen, and D. A. Buehler, Editors). Studies in Avian Biology 49:3-28.

Rotella, J. J. 2007. Nest survival models. Chapter 17 in Program MARK: a gentle introduction (E. Cooch and G. White, Editors). Eighteenth edition.

Roth, A. M., R. W. Rohrbaugh, K. R. Aldinger, M. H. Bakermans, S. Barker Swarthout, D. A. Buehler, J. L. Confer, D. Crawford, C. Friis, R. M. Fowlds, J. L. Larkin, J. Loegering, J. D. Lowe, M. Piorkowski, K. V. Rosenberg, C. Smalling, T. M. Terhune, R. Vallender, T. Will, and P. B. Wood. 2012. Golden-winged Warbler breeding season conservation plan. In Golden-winged Warbler Status Review and Conservation Plan (A. M. Roth, R. W. Rohrbaugh, T. Will, and D. A. Buehler, Editors). www.gwwa.org/plan.

Saab, V. A., R. E. Russell, and J. G. Dudley. 2007. Nest densities of cavity-nesting birds in relation to postfire salvage logging and time since wildfire. Condor 109:97-108.

Sauer, J. R., D. K. Niven, J. E. Hines, D. J. Ziolkowski, Jr, K. L. Pardieck, J. E. Fallon, and W. A. Link. 2017. The North American Breeding Bird Survey, Results and Analysis 1966 2015. Version 2.07.2017 USGS Patuxent Wildlife Research Center, Laurel, MD, USA.

Schmidt, K. A. 2003. Nest predation and population declines in Illinois songbirds: a case for mesopredator effects. Conservation Biology 17:1141-1150.

Schmidt, K. A., S. A. Rush, and R. S. Ostfeld. 2008. Wood Thrush nest success and postfledgling survival across a temporal pulse of small mammal abundance in an oak forest. Journal of Animal Ecology 77:830-837. 
Sperry, J. H., R. G. Peak, D. A. Cimprich, and P. J. Weatherhead. 2008. Snake activity affects seasonal variation in nest predation risk for birds. Journal of Avian Biology 39:379-383.

Streby, H. M., and D. E. Andersen. 2013. Testing common assumptions in studies of songbird nest success. Ibis 155:327-337.

Streby, H. M., G. R. Kramer, S. M. Peterson, and D. E. Andersen. 2018. Evaluating outcomes of management targeting the recovery of a migratory songbird of conservation concern. PeerJ 6:e4319; DOI 10.7717/peerj.4319.

Streby, H. M., J. M. Refsnider, S. M. Peterson, and D. E. Andersen. 2014. Retirement investment theory explains patterns in songbird nest-site choice. Proceedings of the Royal Society of London, Series B 281:20131834.

Streby, H. M., S. M. Peterson, and D. E. Andersen. 2016a. Survival and habitat use of fledgling Golden-winged Warblers in the western Great Lakes Region. In Golden-winged Warbler Ecology, Conservation, and Habitat Management (H. M. Streby, D. E. Andersen, and D. A. Buehler, Editors). Studies in Avian Biology 49:127-140.

Streby, H. M., R. W. Rohrbaugh, D. A. Buehler, D. E. Andersen, R. Vallender, D. I. King, and T. Will. 2016b. Research on Golden-winged Warblers: recent progress and current needs. In Golden-winged Warbler Ecology, Conservation, and Habitat Management (H. M. Streby, D. E. Andersen, and D. A. Buehler, Editors). Studies in Avian Biology 49:217227.

Terhune II, T. M., K. R. Aldinger, D. A. Buehler, D. J. Flaspohler, J. L. Larkin, J. P. Loegering, K. L. Percy, A. M. Roth, C. Smalling, and P. B. Wood. Golden-winged Warbler nest-site habitat selection. In Golden-winged Warbler Ecology, Conservation, and Habitat Management (H. M. Streby, D. E. Andersen, and D. A. Buehler, Editors). Studies in Avian Biology 49:109-125.

Thogmartin, W. E. 2010. Modeling and mapping Golden-winged Warbler abundance to improve regional conservation strategies. Avian Conservation and Ecology 5:12.

Tobler, W. R. 1970. A computer movie simulating growth in the Detroit region. Economic Geography 46:234-240.

Toews, D. P. L., S. A. Taylor, R. Vallender, A. Brelsford, B. G. Butcher, P. W. Messer, and I. J. Lovette. 2016. Plumage genes and little else distinguish the genomes of hybridizing warblers. Current Biology 26:2313-2318.

Tozer, D. C., D. M. Burke, E. Nol, and K. A. Elliot. 2012. Managing ecological traps: logging and sapsucker nest predation by bears. Journal of Wildlife Management 76:887-898.

U.S. Forest Service. 2006. Monongahela National Forest Land and Resource Management Plan. United States Department of Agriculture Forest Service, Elkins, WV, USA.

U.S. National Agricultural Statistics Service. 2017. West Virginia Annual Bulletin No. 48. U.S. Department of Agriculture National Agricultural Statistics Service West Virginia Field Office, Charleston, WV, USA.

U.S. Natural Resources Conservation Service (2012). Golden-winged Warbler. USDA Natural Resources Conservation Service, Washington, DC, USA. https://www.nrcs.usda.gov/ wps/portal/nrcs/detailfull/national/programs/financial/whip/?cid=stelprdb1046990. 
Vallender, R., V. L. Friesen, and R. J. Roberston. 2007. Paternity and performance of Goldenwinged Warblers (Vermivora chrysoptera) and Golden-winged $\times$ Blue-winged Warbler (V. pinus) hybrids at the leading edge of a hybrid zone. Behavioral Ecology and Sociobiology 61:1797-1807.

Vallender, R., S. L. Van Wilgenburg, L. P. Bulluck, A. Roth, R. Canterbury, J. L. Larkin, R. M. Fowlds, and I. J. Lovette. 2009. Extensive rangewide mitochondrial introgression indicates substantial cryptic hybridization in the Golden-winged Warbler (Vermivora chrysoptera). Avian Conservation and Ecology 4:4.

West Virginia Division of Forestry. 2010. West Virginia statewide forest resource assessment. West Virginia Division of Forestry, Charleston, WV, USA. www.wvforestry.com/DOF100Assessment_Revised_091310_Part1.pdf.

White, G. C., and K. P. Burnham. 1999. Program MARK: survival estimation from populations of marked animals. Bird Study 46:S120-S139.

Will, T. C. 1986. The behavioral ecology of species replacements: Blue-winged and Goldenwinged warblers in Michigan. Ph.D. dissertation, University of Michigan, Ann Arbor, MI, USA. 


\section{TABLES}

Table 1. Covariates $(n=35)$ and scales $(n=4)$ used in Golden-winged Warbler nest survival analysis indicated by measurement unit. Categorical covariates indicated by "X". Lack of measurement unit indicates that covariate was not used in Golden-winged Warbler nest survival analysis.

\begin{tabular}{|c|c|c|c|c|}
\hline Covariate & Nest & Territory & Pasture & Study area \\
\hline \multicolumn{5}{|l|}{ Land cover } \\
\hline Cover type & $\mathrm{X}$ & & & \\
\hline Distance to forest & $\mathrm{m}$ & & & \\
\hline Grass cover (11.3-m plot) & $\%$ & & & \\
\hline Rubus cover (11.3-m plot) & $\%$ & & & \\
\hline Shrub cover (11.3-m plot) & $\%$ & & & \\
\hline Forest cover type & & $\%$ & & \\
\hline Herbaceous cover type & & $\%$ & ha & \\
\hline Shrubland cover type & & $\%$ & ha & \\
\hline \multicolumn{5}{|l|}{ Management regime $^{\dagger}$} \\
\hline Management type & $X$ & & & \\
\hline GM & & $\%$ & $\%$ & \\
\hline $\mathrm{Gm}$ & & $\%$ & $\%$ & \\
\hline gM & & $\%$ & $\%$ & \\
\hline GMm & & $\%$ & $\%$ & \\
\hline GgM & & $\%$ & $\%$ & \\
\hline gMm & & $\%$ & $\%$ & \\
\hline Ggm & & $\%$ & $\%$ & \\
\hline gm & & $\%$ & $\%$ & \\
\hline \multicolumn{5}{|l|}{ Spatial location } \\
\hline Minimum elevation & $\mathrm{m}$ & $\mathrm{m}$ & $\mathrm{m}$ & \\
\hline Pasture & & & $\mathrm{X}$ & \\
\hline Study area & & & & $X$ \\
\hline \multicolumn{5}{|l|}{ Time } \\
\hline Day of nesting season & \# days & & & \\
\hline Year & Year & & & \\
\hline Years since management & \# years & & & \\
\hline
\end{tabular}

${ }^{\dagger}$ Grazed and managed (GM), grazed and unmanaged (Gm), ungrazed and managed (gM), all grazed (GMm), all managed (GgM), all ungrazed (gMm), all unmanaged (Ggm), and ungrazed and unmanaged (gm) 
Table 2. Covariates $(n=35)$ and scales $(n=4)$ used in Golden-winged Warbler population trend modeling indicated by measurement unit. Categorical covariates indicated by " $\mathrm{X}$ ". Lack of measurement unit indicates that covariate was not used in Golden-winged Warbler population trend analysis.

\begin{tabular}{|c|c|c|c|c|}
\hline Variable & Pasture & $\begin{array}{l}1.5-\mathrm{km} \\
\text { pasture } \\
\text { buffer }\end{array}$ & $\begin{array}{c}5-\mathrm{km} \\
\text { pasture } \\
\text { buffer }\end{array}$ & $\begin{array}{c}\text { Study } \\
\text { area }\end{array}$ \\
\hline \multicolumn{5}{|l|}{ Land cover } \\
\hline Shrub cover (11.3-m plot) & $\%$ & & & \\
\hline Forest cover type & & $\%$ & $\%$ & \\
\hline Herbaceous cover type & ha & $\%$ & $\%$ & \\
\hline Shrubland cover type & ha & $\%$ & $\%$ & \\
\hline \multicolumn{5}{|l|}{ Management regime ${ }^{\dagger}$} \\
\hline GM & $\%$ & & & \\
\hline Gm & $\%$ & & & \\
\hline gM & $\%$ & & & \\
\hline GMm & $\%$ & & & \\
\hline GgM & $\%$ & & & \\
\hline gMm & $\%$ & & & \\
\hline Ggm & $\%$ & & & \\
\hline gm & $\%$ & & & \\
\hline \multicolumn{5}{|l|}{ Spatial location } \\
\hline Minimum elevation & $\mathrm{m}$ & $\mathrm{m}$ & $\mathrm{m}$ & \\
\hline Pasture & $\mathrm{X}$ & & & \\
\hline Study area & & & & $\mathrm{X}$ \\
\hline \multicolumn{5}{|l|}{ Time } \\
\hline Years since management & \# years & & & \\
\hline \multicolumn{5}{|l|}{ Vermivora demographics } \\
\hline $\begin{array}{l}\text { Golden-winged Warbler adult male annual } \\
\text { returns }\end{array}$ & $\%$ & & & \\
\hline Golden-winged Warbler nest daily survival & $\%$ & & & \\
\hline Golden-winged Warbler second year males & $\%$ & & & \\
\hline Blue-winged Warbler male density & \#/ ha & & & \\
\hline Blue-winged Warbler female density & \#/ ha & & & \\
\hline Blue-winged Warbler density & \#/ ha & & & \\
\hline Vermivora hybrid male density & \#/ ha & & & \\
\hline Vermivora hybrid female density & \#/ ha & & & \\
\hline Vermivora hybrid density & \#/ ha & & & \\
\hline Non-Golden-winged Warbler male density & \# / ha & & & \\
\hline Non-Golden-winged Warbler female density & \# / ha & & & \\
\hline Non-Golden-winged Warbler density & \#/ ha & & & \\
\hline
\end{tabular}


Table 3. Full model-selection results for daily survival rate of Golden-winged Warbler (Vermivora chrysoptera) nests from pastures in Pocahontas and Randolph counties, West Virginia during 2008-2014. We used the nest survival model of package RMark (version 2.2.4, Laake 2013) in program R (version 3.4.4, R Development Core Team 2018), which is an interface to program MARK (version 9.0, White and Burnham 1999), and Akaike's Information Criterion adjusted for small sample size $\left(\mathrm{AIC}_{\mathrm{c}}\right)$ for analysis of daily survival rate of nests. $\mathrm{K}$ is the number of parameters in the model, $\mathrm{AIC}_{\mathrm{c}}$ is Akaike's Information Criterion adjusted for small sample size, $\Delta \mathrm{AIC}_{\mathrm{c}}$ is the difference in $\mathrm{AIC}_{\mathrm{c}}$ values between individual models and the top model, $w_{i}$ is the model weight, and LL is the log-likelihood. Models with $\Delta \mathrm{AIC}_{\mathrm{c}} \leq 2.0$ were considered plausible.

\begin{tabular}{|c|c|c|c|c|c|}
\hline Model $^{\dagger}$ & $\mathrm{K}$ & $\mathrm{AIC}_{\mathrm{c}}$ & $\Delta \mathrm{AIC}_{\mathrm{c}}$ & $w_{i}$ & LL \\
\hline Study area & 2 & 416.21 & 0.00 & 0.06 & -206.10 \\
\hline Pasture herbaceous + pasture shrubland & 3 & 416.52 & 0.31 & 0.05 & -205.25 \\
\hline Pasture shrubland & 2 & 416.86 & 0.65 & 0.04 & -206.43 \\
\hline Pasture + YSM & 7 & 416.88 & 0.67 & 0.04 & -201.41 \\
\hline Territory gm & 2 & 416.97 & 0.76 & 0.04 & -206.48 \\
\hline Study area + YSM & 3 & 417.02 & 0.82 & 0.04 & -205.51 \\
\hline Territory GMm + territory scale GMm² & 3 & 417.26 & 1.05 & 0.03 & -205.63 \\
\hline Territory Ggm + territory Ggm² & 3 & 417.42 & 1.21 & 0.03 & -205.71 \\
\hline Territory gMm & 2 & 417.55 & 1.34 & 0.03 & -206.78 \\
\hline Nest elevation & 2 & 417.65 & 1.44 & 0.03 & -206.83 \\
\hline Territory min. elevation & 2 & 417.93 & 1.73 & 0.02 & -206.97 \\
\hline Pasture & 6 & 418.05 & 1.84 & 0.02 & -203.00 \\
\hline Nest elevation + Nest elevation ${ }^{2}$ & 3 & 418.13 & 1.92 & 0.02 & -206.06 \\
\hline Pasture herbaceous + pasture herbaceous ${ }^{2}$ & 3 & 418.24 & 2.03 & 0.02 & -206.12 \\
\hline Territory min. elevation + territory min. elevation² & 3 & 418.24 & 2.03 & 0.02 & -206.12 \\
\hline Territory herbaceous & 2 & 418.33 & 2.12 & 0.02 & -207.17 \\
\hline Nest grass cover + nest grass cover ${ }^{2}$ & 3 & 418.45 & 2.24 & 0.02 & -206.22 \\
\hline Territory herbaceous + territory herbaceous ${ }^{2}$ & 3 & 418.53 & 2.32 & 0.02 & -206.26 \\
\hline Territory gm + territory gm ${ }^{2}$ & 3 & 418.59 & 2.38 & 0.02 & -206.29 \\
\hline Nest grass cover & 2 & 418.72 & 2.51 & 0.02 & -207.36 \\
\hline Pasture shrubland + pasture shrubland ${ }^{2}$ & 3 & 418.79 & 2.58 & 0.02 & -206.39 \\
\hline Pasture gMm & 2 & 418.87 & 2.66 & 0.02 & -207.43 \\
\hline Pasture GMm & 2 & 418.87 & 2.66 & 0.02 & -207.44 \\
\hline Study area $\times$ YSM & 4 & 418.93 & 2.72 & 0.01 & -205.46 \\
\hline Territory Ggm & 2 & 418.96 & 2.76 & 0.01 & -207.48 \\
\hline Pasture gm & 2 & 419.04 & 2.83 & 0.01 & -207.52 \\
\hline Day of nesting season + Day of nesting season ${ }^{2}$ & 3 & 419.09 & 2.88 & 0.01 & -206.54 \\
\hline Territory GMm & 2 & 419.18 & 2.97 & 0.01 & -207.59 \\
\hline Territory shrubland + territory shrubland ${ }^{2}$ & 3 & 419.19 & 2.98 & 0.01 & -206.59 \\
\hline Nest cover type & 2 & 419.23 & 3.02 & 0.01 & -207.61 \\
\hline Pasture min. elevation + pasture min. elevation ${ }^{2}$ & 3 & 419.27 & 3.06 & 0.01 & -206.63 \\
\hline Pasture herbaceous & 2 & 419.39 & 3.18 & 0.01 & -207.69 \\
\hline Territory herbaceous + territory shrubland & 3 & 419.41 & 3.21 & 0.01 & -206.70 \\
\hline Territory gMm + territory gMm² & 3 & 419.51 & 3.30 & 0.01 & -206.75 \\
\hline Pasture Ggm & 2 & 419.51 & 3.30 & 0.01 & -207.76 \\
\hline Territory shrubland & 2 & 419.52 & 3.31 & 0.01 & -207.76 \\
\hline Pasture GgM & 2 & 419.52 & 3.31 & 0.01 & -207.76 \\
\hline Constant & 1 & 419.80 & 3.59 & 0.01 & -208.90 \\
\hline
\end{tabular}




\begin{tabular}{|c|c|c|c|c|c|}
\hline Model $^{\dagger}$ & $\mathrm{K}$ & $\mathrm{AIC}_{\mathrm{c}}$ & $\Delta \mathrm{AIC}_{\mathrm{c}}$ & $w_{i}$ & $\mathrm{LL}$ \\
\hline Pasture GM & 2 & 419.85 & 3.64 & 0.01 & -207.92 \\
\hline Territory GM & 2 & 419.96 & 3.75 & 0.01 & -207.98 \\
\hline Territory GgM & 2 & 420.01 & 3.80 & 0.01 & -208.00 \\
\hline Day of nesting season & 2 & 420.04 & 3.83 & 0.01 & -208.02 \\
\hline Pasture gm + pasture gm² & 3 & 420.08 & 3.87 & 0.01 & -207.03 \\
\hline Pasture min. elevation & 2 & 420.25 & 4.04 & 0.01 & -208.12 \\
\hline YSM + YSM ${ }^{2}$ & 3 & 420.26 & 4.05 & 0.01 & -207.13 \\
\hline Nest shrub cover & 2 & 420.34 & 4.13 & 0.01 & -208.17 \\
\hline Pasture gMm + pasture gMm² & 3 & 420.53 & 4.32 & 0.01 & -207.26 \\
\hline Pasture GMm + pasture GMm² & 3 & 420.54 & 4.33 & 0.01 & -207.26 \\
\hline Nest dist. to forest & 2 & 420.67 & 4.46 & 0.01 & -208.33 \\
\hline Territory forest & 2 & 421.00 & 4.79 & 0.01 & -208.50 \\
\hline Territory GgM + territory GgM² & 3 & 421.16 & 4.96 & 0.00 & -207.58 \\
\hline Nest shrub cover + Nest shrub cover ${ }^{2}$ & 3 & 421.37 & 5.16 & 0.00 & -207.68 \\
\hline Pasture Ggm + pasture Ggm² & 3 & 421.37 & 5.16 & 0.00 & -207.68 \\
\hline Pasture GgM + pasture GgM² & 3 & 421.39 & 5.18 & 0.00 & -207.69 \\
\hline Pasture Gm & 2 & 421.39 & 5.18 & 0.00 & -208.69 \\
\hline YSM & 2 & 421.64 & 5.43 & 0.00 & -208.82 \\
\hline Pasture GM + pasture GM² & 3 & 421.72 & 5.51 & 0.00 & -207.86 \\
\hline Territory Gm & 2 & 421.79 & 5.58 & 0.00 & -208.89 \\
\hline Pasture gM & 2 & 421.79 & 5.58 & 0.00 & -208.89 \\
\hline Territory gM & 2 & 421.79 & 5.59 & 0.00 & -208.90 \\
\hline Nest Rubus cover & 2 & 421.80 & 5.59 & 0.00 & -208.90 \\
\hline Territory GM + territory GM² & 3 & 421.81 & 5.60 & 0.00 & -207.90 \\
\hline Territory Gm + territory $\mathrm{Gm}^{2}$ & 3 & 421.82 & 5.61 & 0.00 & -207.90 \\
\hline Territory forest cover + territory forest cover ${ }^{2}$ & 3 & 422.05 & 5.84 & 0.00 & -208.02 \\
\hline Pasture Gm + pasture $\mathrm{Gm}^{2}$ & 3 & 422.07 & 5.87 & 0.00 & -208.03 \\
\hline Nest dist. to forest + nest dist. to forest ${ }^{2}$ & 3 & 422.12 & 5.92 & 0.00 & -208.06 \\
\hline Pasture GgM × YSM & 4 & 422.13 & 5.92 & 0.00 & -207.05 \\
\hline Nest management regime & 4 & 422.37 & 6.16 & 0.00 & -207.17 \\
\hline Territory gM × YSM & 4 & 422.62 & 6.41 & 0.00 & -207.30 \\
\hline Territory GM × YSM & 4 & 422.78 & 6.57 & 0.00 & -207.38 \\
\hline Territory gM + territory gM ${ }^{2}$ & 3 & 423.03 & 6.82 & 0.00 & -208.51 \\
\hline Pasture GM $\times$ YSM & 4 & 423.28 & 7.07 & 0.00 & -207.63 \\
\hline Territory GgM × YSM & 4 & 423.34 & 7.13 & 0.00 & -207.66 \\
\hline Pasture gM + pasture $\mathrm{gM}^{2}$ & 3 & 423.53 & 7.32 & 0.00 & -208.76 \\
\hline Nest Rubus cover + Nest Rubus cover ${ }^{2}$ & 3 & 423.56 & 7.35 & 0.00 & -208.77 \\
\hline Pasture $\mathrm{gM} \times \mathrm{YSM}$ & 4 & 425.00 & 8.79 & 0.00 & -208.49 \\
\hline Pasture $\times$ YSM & 12 & 425.90 & 9.69 & 0.00 & -200.86 \\
\hline Year & 7 & 430.15 & 13.94 & 0.00 & -208.05 \\
\hline
\end{tabular}

${ }^{\dagger}$ Years since management (YSM), grazed and managed (GM), grazed and unmanaged (Gm), ungrazed and managed (gM), all grazed (GMm), all managed (GgM), all ungrazed (gMm), all unmanaged (Ggm), and ungrazed and unmanaged (gm) 
Table 4. Beta coefficients and 95\% lower (LCL) and upper (UCL) confidence limits for covariates in best-supported $\left(\Delta \mathrm{AIC}_{\mathrm{c}} \leq 2.0\right)$ models of daily survival rate of Golden-winged Warbler (Vermivora chrysoptera) nests from pastures in Pocahontas and Randolph counties, West Virginia during 2008-2014. Bold text represents covariates that we considered biologically important because the 95\% confidence interval did not overlap zero.

\begin{tabular}{|c|c|c|c|c|c|}
\hline Model $^{\dagger}$ & Covariate $^{\dagger}$ & $\beta$ & SE & LCL & UCL \\
\hline \multirow[t]{2}{*}{ Study area } & Intercept (Randolph) & 2.937 & 0.194 & 2.556 & 3.317 \\
\hline & Pocahontas & 0.634 & 0.264 & 0.116 & 1.151 \\
\hline \multirow{3}{*}{$\begin{array}{l}\text { Pasture herbaceous + } \\
\text { pasture shrubland }\end{array}$} & Intercept & 2.773 & 0.234 & 2.314 & 3.232 \\
\hline & Pasture herbaceous & -0.068 & 0.044 & -0.154 & 0.017 \\
\hline & Pasture shrubland & 0.026 & 0.012 & 0.003 & 0.049 \\
\hline \multirow[t]{2}{*}{ Pasture shrubland } & Intercept & 2.915 & 0.216 & 2.492 & 3.338 \\
\hline & Pasture shrubland & 0.009 & 0.004 & 0.001 & 0.018 \\
\hline \multirow[t]{7}{*}{ Pasture + YSM } & Intercept (Coberly Sods) & 3.455 & 0.364 & 2.741 & 4.169 \\
\hline & Forinash & -0.440 & 0.512 & -1.443 & 0.562 \\
\hline & Gay Sharp & -0.462 & 0.474 & -1.390 & 0.467 \\
\hline & Hannah & 0.761 & 0.489 & -0.198 & 1.720 \\
\hline & Hoover & 0.648 & 0.419 & -0.174 & 1.469 \\
\hline & Washout & -0.604 & 0.456 & -1.498 & 0.289 \\
\hline & YSM & -0.178 & 0.100 & -0.375 & 0.019 \\
\hline \multirow[t]{2}{*}{ Territory gm } & Intercept & 3.465 & 0.152 & 3.167 & 3.764 \\
\hline & Territory gm & -0.793 & 0.339 & -1.457 & -0.128 \\
\hline \multirow[t]{3}{*}{ Study area + YSM } & Intercept (Randolph) & 3.051 & 0.224 & 2.612 & 3.491 \\
\hline & Pocahontas & 0.720 & 0.277 & 0.177 & 1.262 \\
\hline & YSM & -0.104 & 0.095 & -0.290 & 0.083 \\
\hline \multirow{3}{*}{$\begin{array}{l}\text { Territory GMm + territory } \\
\text { GMm² }^{2}\end{array}$} & Intercept & 2.776 & 0.260 & 2.267 & 3.285 \\
\hline & Territory GMm & 4.346 & 2.113 & 0.205 & 8.488 \\
\hline & Territory GMm² & -3.815 & 2.109 & -7.949 & 0.318 \\
\hline \multirow{3}{*}{$\begin{array}{l}\text { Territory Ggm + territory } \\
\text { Ggm² }^{2}\end{array}$} & Intercept & 3.838 & 0.267 & 3.315 & 4.360 \\
\hline & Territory Ggm & -3.338 & 1.502 & -6.283 & -0.393 \\
\hline & Territory Ggm² & 2.761 & 1.438 & -0.057 & 5.579 \\
\hline \multirow[t]{2}{*}{ Territory gMm } & Intercept & 3.471 & 0.156 & 3.165 & 3.776 \\
\hline & Territory gMm & -0.692 & 0.319 & -1.318 & -0.066 \\
\hline \multirow[t]{2}{*}{ Nest elevation } & Intercept & 0.048 & 1.615 & -3.119 & 3.214 \\
\hline & Nest elevation & 0.003 & 0.002 & 0.000 & 0.007 \\
\hline \multirow[t]{2}{*}{ Territory min. elevation } & Intercept & 0.086 & 1.661 & -3.170 & 3.342 \\
\hline & Territory min. elevation & 0.003 & 0.002 & 0.000 & 0.007 \\
\hline \multirow[t]{6}{*}{ Pasture } & Intercept (Coberly Sods) & 3.171 & 0.323 & 2.538 & 3.804 \\
\hline & Forinash & -0.295 & 0.506 & -1.286 & 0.696 \\
\hline & Gay Sharp & -0.389 & 0.472 & -1.314 & 0.535 \\
\hline & Hannah & 0.630 & 0.482 & -0.314 & 1.575 \\
\hline & Hoover & 0.573 & 0.415 & -0.241 & 1.387 \\
\hline & Washout & -0.459 & 0.449 & -1.339 & 0.421 \\
\hline \multirow{3}{*}{$\begin{array}{l}\text { Nest elevation + Nest } \\
\text { elevation }{ }^{2}\end{array}$} & Intercept & -21.230 & 27.184 & -74.511 & 32.050 \\
\hline & Nest elevation & 0.048 & 0.056 & -0.063 & 0.158 \\
\hline & Nest elevation $^{2}$ & -0.000 & 0.000 & -0.000 & 0.000 \\
\hline
\end{tabular}

${ }^{\dagger}$ Years since management (YSM), grazed and managed (GM), grazed and unmanaged (Gm), ungrazed and managed (gM), all grazed (GMm), all managed (GgM), all ungrazed (gMm), all unmanaged (Ggm), and ungrazed and unmanaged (gm) 
Table 5. Model-selection results for Golden-winged Warbler (Vermivora chrysoptera) population trends from pastures in Pocahontas and Randolph counties, West Virginia during 2008-2014. We used package Ime4 (version 1.1-16, Bates et al. 2015) in program R (version 3.4.4, R Development Core Team 2018) to formulate Poisson lognormal mixed effect models of density fitted with Laplace estimation. Models included one linear covariate term and an interaction with years since management. The constant density model (intercept only) and a model with only years since management did not include this interaction. All models included a random intercept for pasture, a random slope for years since management, and an offset for the log of the amount of shrubland cover type per pasture. We used Akaike's Information Criterion adjusted for small sample size $\left(\mathrm{AIC}_{\mathrm{c}}\right.$ ) to select among models. $\mathrm{K}$ is the number of parameters in the model, $\mathrm{AIC}_{\mathrm{c}}$ is Akaike's Information Criterion adjusted for small sample size, $\Delta \mathrm{AIC}_{\mathrm{c}}$ is the difference in $\mathrm{AIC}_{\mathrm{c}}$ values between individual models and the top model, $w_{i}$ is the model weight, and LL is the log-likelihood. Models with $\Delta \mathrm{AIC}_{\mathrm{c}} \leq 2.0$ were considered plausible.

\begin{tabular}{|c|c|c|c|c|c|}
\hline Model & $\mathrm{K}$ & $\mathrm{AIC}_{\mathrm{c}}$ & $\Delta \mathrm{AIC}_{\mathrm{c}}$ & $w_{i}$ & LL \\
\hline Pasture nest daily survival rate & 7 & 172.69 & 0.00 & 0.53 & 0.53 \\
\hline 1.5-km min. elevation & 7 & 176.08 & 3.39 & 0.10 & 0.62 \\
\hline Study area & 7 & 176.12 & 3.43 & 0.09 & 0.72 \\
\hline 5-km shrubland & 7 & 176.16 & 3.47 & 0.09 & 0.81 \\
\hline 5-km min. elevation & 7 & 177.73 & 5.04 & 0.04 & 0.85 \\
\hline Pasture herbaceous & 7 & 178.72 & 6.02 & 0.03 & 0.88 \\
\hline Pasture shrub cover & 7 & 179.71 & 7.02 & 0.02 & 0.89 \\
\hline 5-km forest & 7 & 180.27 & 7.58 & 0.01 & 0.91 \\
\hline Second-year Golden-winged Warbler males & 7 & 180.30 & 7.61 & 0.01 & 0.92 \\
\hline YSM & 5 & 180.47 & 7.77 & 0.01 & 0.93 \\
\hline Pasture min. elevation & 7 & 180.57 & 7.88 & 0.01 & 0.94 \\
\hline Pasture GMm & 7 & 181.54 & 8.85 & 0.01 & 0.95 \\
\hline Pasture gMm & 7 & 181.55 & 8.85 & 0.01 & 0.95 \\
\hline 1.5-km shrubland & 7 & 181.73 & 9.04 & 0.01 & 0.96 \\
\hline 5-km shrubland & 7 & 182.35 & 9.66 & 0.00 & 0.96 \\
\hline Pasture gm & 7 & 182.45 & 9.75 & 0.00 & 0.97 \\
\hline Male non-Golden-winged Warbler density & 7 & 182.48 & 9.79 & 0.00 & 0.97 \\
\hline Pasture Gm & 7 & 182.67 & 9.98 & 0.00 & 0.97 \\
\hline 1.5-km herbaceous & 7 & 182.86 & 10.17 & 0.00 & 0.98 \\
\hline Pasture GM & 7 & 183.58 & 10.89 & 0.00 & 0.98 \\
\hline Pasture GgM & 7 & 183.87 & 11.18 & 0.00 & 0.98 \\
\hline Pasture Ggm & 7 & 183.89 & 11.20 & 0.00 & 0.98 \\
\hline Hybrid male density & 7 & 184.01 & 11.32 & 0.00 & 0.98 \\
\hline Male Blue-winged Warbler density & 7 & 184.10 & 11.41 & 0.00 & 0.99 \\
\hline Total Blue-winged Warbler density & 7 & 184.11 & 11.41 & 0.00 & 0.99 \\
\hline Total non-Golden-winged Warbler density & 7 & 184.15 & 11.46 & 0.00 & 0.99 \\
\hline Female Blue-winged Warbler density & 7 & 184.28 & 11.58 & 0.00 & 0.99 \\
\hline Pasture shrubland & 7 & 184.28 & 11.59 & 0.00 & 0.99 \\
\hline Total hybrid density & 7 & 184.41 & 11.72 & 0.00 & 0.99 \\
\hline 1.5 -km forest & 7 & 184.46 & 11.77 & 0.00 & 1.00 \\
\hline Female non-Golden-winged Warbler density & 7 & 185.24 & 12.55 & 0.00 & 1.00 \\
\hline Constant & 4 & 185.35 & 12.66 & 0.00 & 1.00 \\
\hline Pasture gM & 7 & 185.60 & 12.91 & 0.00 & 1.00 \\
\hline Male Golden-winged Warbler return rate & 7 & 185.96 & 13.27 & 0.00 & 1.00 \\
\hline Female hybrid density & 7 & 186.17 & 13.47 & 0.00 & 1.00 \\
\hline Pasture & 15 & 190.51 & 17.82 & 0.00 & 1.00 \\
\hline
\end{tabular}


Table 6. Beta coefficients and 95\% lower (LCL) and upper (UCL) confidence limits for covariates in best-supported $\left(\Delta \mathrm{AIC}_{\mathrm{c}} \leq 2.0\right)$ models of Golden-winged Warbler (Vermivora chrysoptera) population trend from pastures in Pocahontas and Randolph counties, West Virginia during 2008-2014. Bold text represents covariates that we considered biologically important because the 95\% confidence interval did not overlap zero. Note that covariates were mean-centered and scaled by dividing by their standard deviation using the scale function in the base package in program R (version 3.4.4, R Development Core Team 2018). Mean-centering and scaling reportedly aids in model convergence, reduces multicollinearity and estimated standard errors, and enhances interpretability (Afshartous and Preston 2011).

\begin{tabular}{lllllr}
\hline Model $^{\dagger}$ & Covariate $^{\dagger}$ & \multicolumn{1}{c}{$\beta$} & SE & \multicolumn{1}{l}{ LCL } & \multicolumn{1}{c}{ UCL } \\
\hline Pasture nest DSR & Intercept & $\mathbf{1 . 7 2 6}$ & $\mathbf{0 . 2 3 2}$ & $\mathbf{- 2 . 1 8 1}$ & $\mathbf{- 1 . 2 7 0}$ \\
& Pasture nest DSR & -0.088 & 0.243 & -0.564 & 0.387 \\
& YSM & $\mathbf{- 0 . 6 2 1}$ & $\mathbf{0 . 1 2 0}$ & $\mathbf{- 0 . 8 5 6}$ & $\mathbf{- 0 . 3 8 5}$ \\
& Pasture nest DSR $\times$ YSM & $\mathbf{0 . 3 5 1}$ & $\mathbf{0 . 0 9 8}$ & $\mathbf{0 . 1 5 9}$ & $\mathbf{0 . 5 4 3}$ \\
\hline
\end{tabular}

${ }^{\dagger}$ Years since management (YSM), daily survival rate (DSR) 


\section{FIGURES}
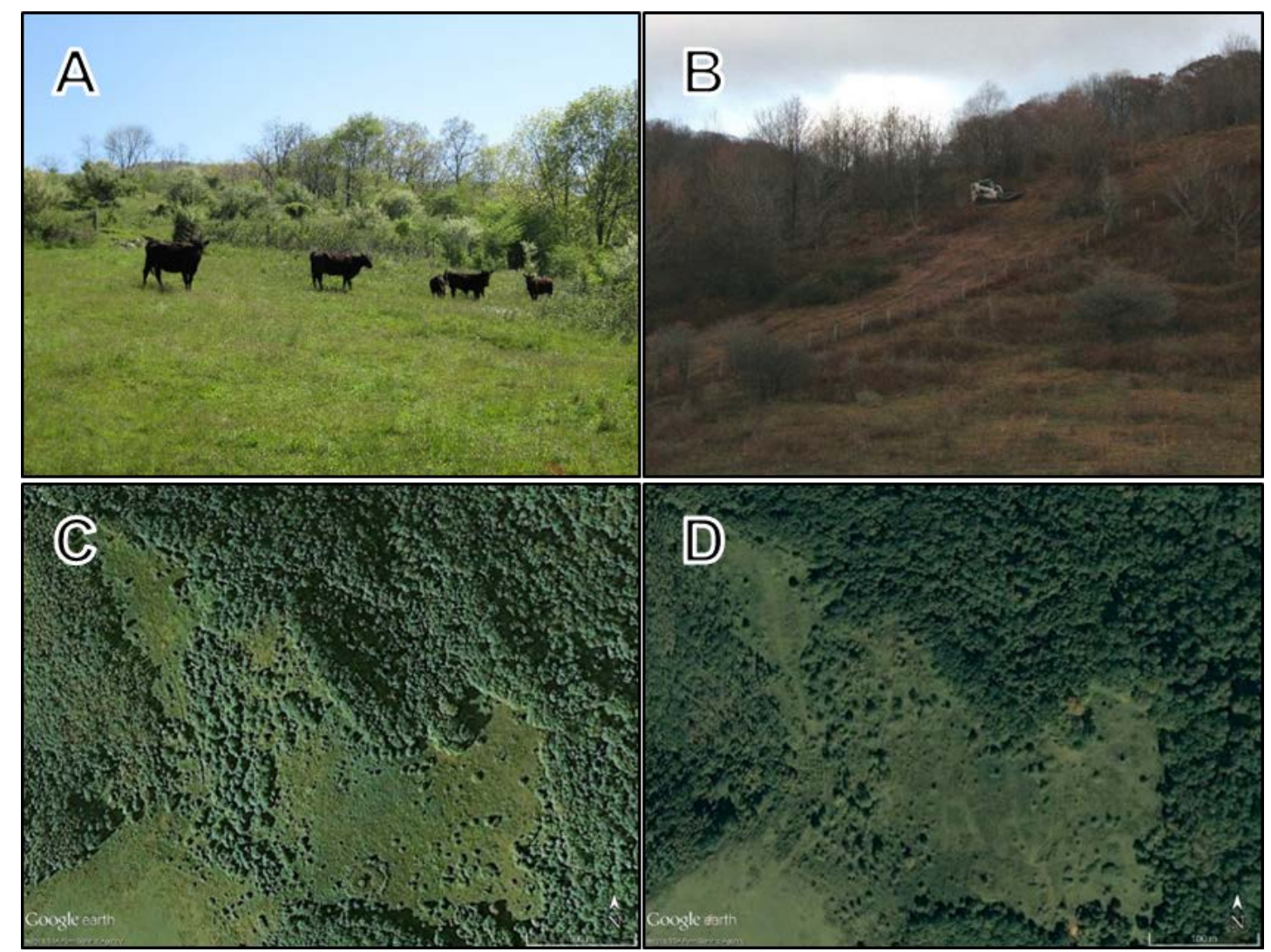

Figure 1. Shrubland cover type on our pastures in West Virginia during 2008-2014 was maintained with cattle grazing (panel A) and mechanical vegetation management consisting of hand-cutting shrubs and trees with chainsaws and brush hogging with a compact track loader or tractor with brush hog attachment (panel B). One abandoned pasture was neither grazed nor mechanically managed. Mechanical vegetation management occurred during Fall 2008 on pastures in Randolph County and during Fall 2009 on our pastures in Pocahontas County. Areas targeted for management were characterized by a uniform closed-canopy thicket of shrubs, usually hawthorn (Crataegus spp), autumn olive (Elaeagnus umbellata), and multiflora rose (Rosa multiflora), where (1) Golden-winged Warbler nest-site characteristics were disappearing to vegetative succession, (2) cattle forage was absent due to shading, and (3) shrubs formed a physical barrier to cattle. Note dense patch of shrubs left of center pre-treatment (2007) in panel $\mathrm{C}$ and post-treatment (2009) in panel D. 


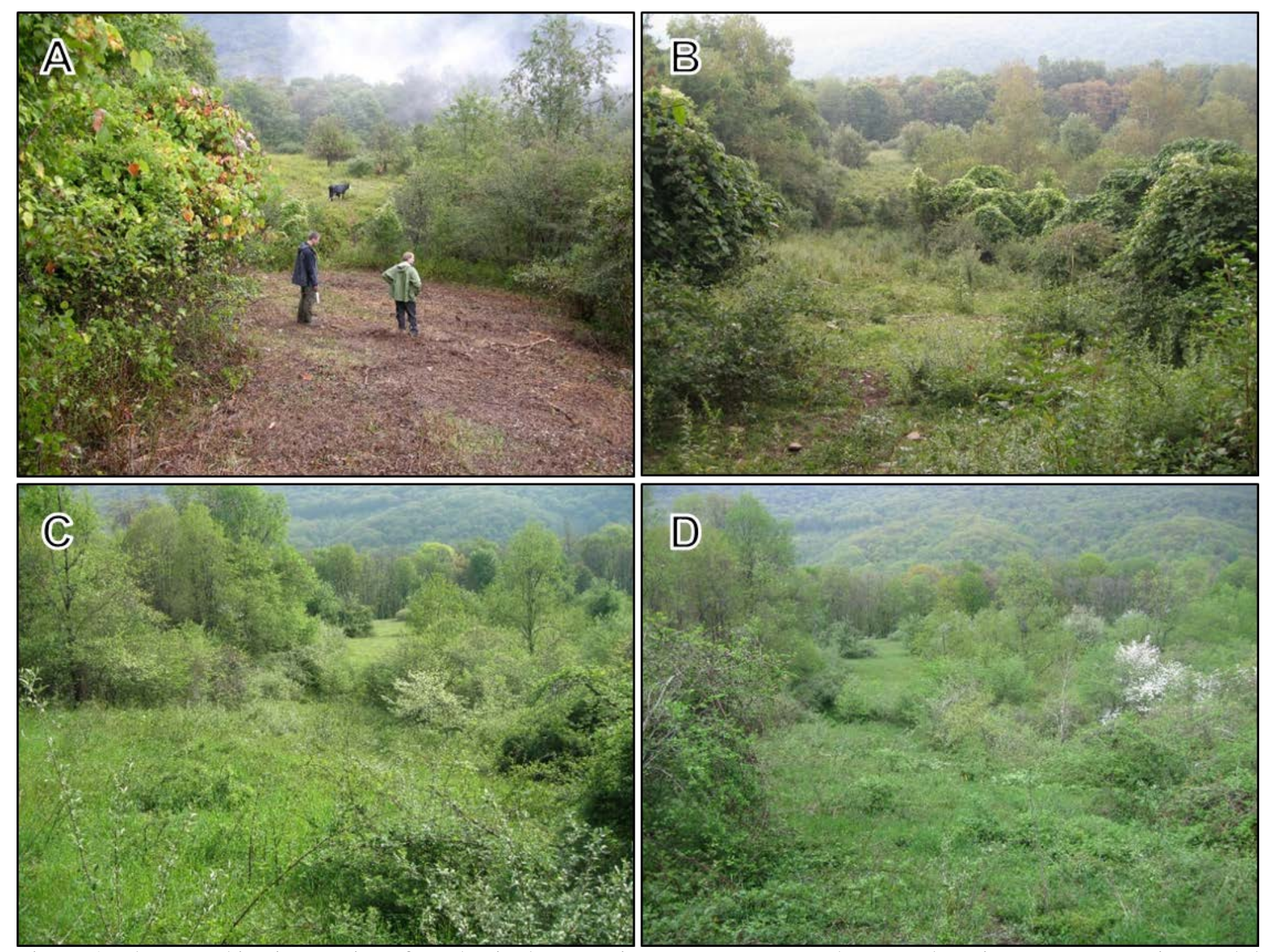

Figure 2. Photographic time series of mechanical vegetation management at the same location on a pasture in Randolph County immediately following management (panel A, 12 September 2008), 2 years post-management (panel B, 11 August 2010), 4 years post management (panel C, 2 May 2012), and 5 years post-management (panel D, 11 May 2013). 

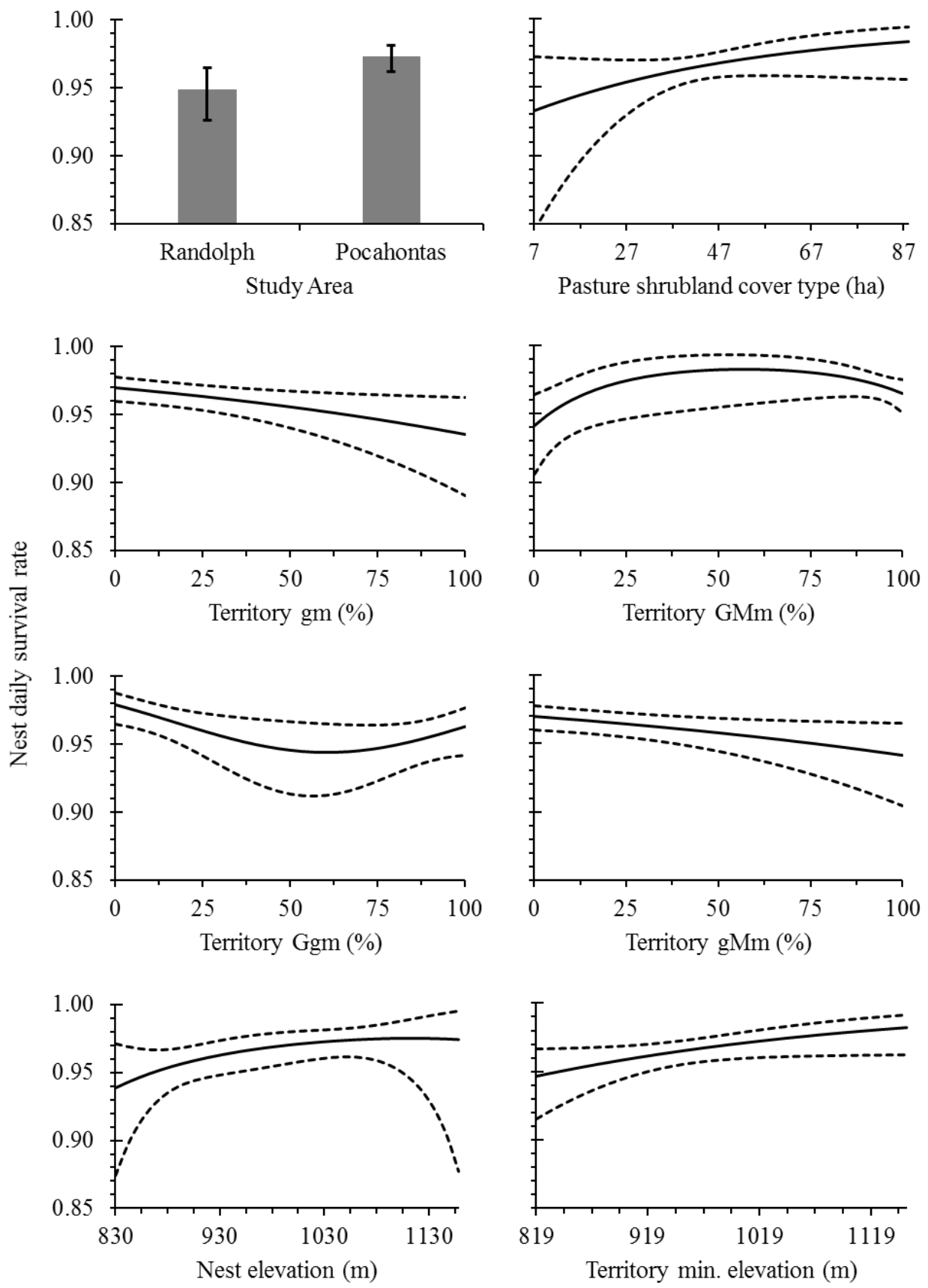

Figure 3. Among candidate models of Golden-winged Warbler nest daily survival date (DSR) from nests in Pocahontas and Randolph counties, West Virginia during 2008-2014, 13 models had $\Delta \mathrm{AIC}_{\mathrm{c}} \leq 2.0$ and were considered plausible (Burnham and Anderson 2002). Nest DSR was higher on pastures in Pocahontas County (mean $=0.973,95 \%$ confidence interval $(\mathrm{CI})=0.962-$ 0.981) than on pastures in Randolph County (mean $=0.949$, 95\% CI $=0.926-0.965$ ), positively associated with amount of pasture-scale shrubland cover type, proportion of territory-scale grazed (GMm) shrubland cover type, and nest- and territory-scale elevation, and negatively associated with proportions of territory-scale ungrazed and unmanaged (gm), unmanaged (Ggm), and ungrazed (gMm) shrubland cover types. Solid line represents mean nest DSR and dashed lines represent 95\% CIs. 


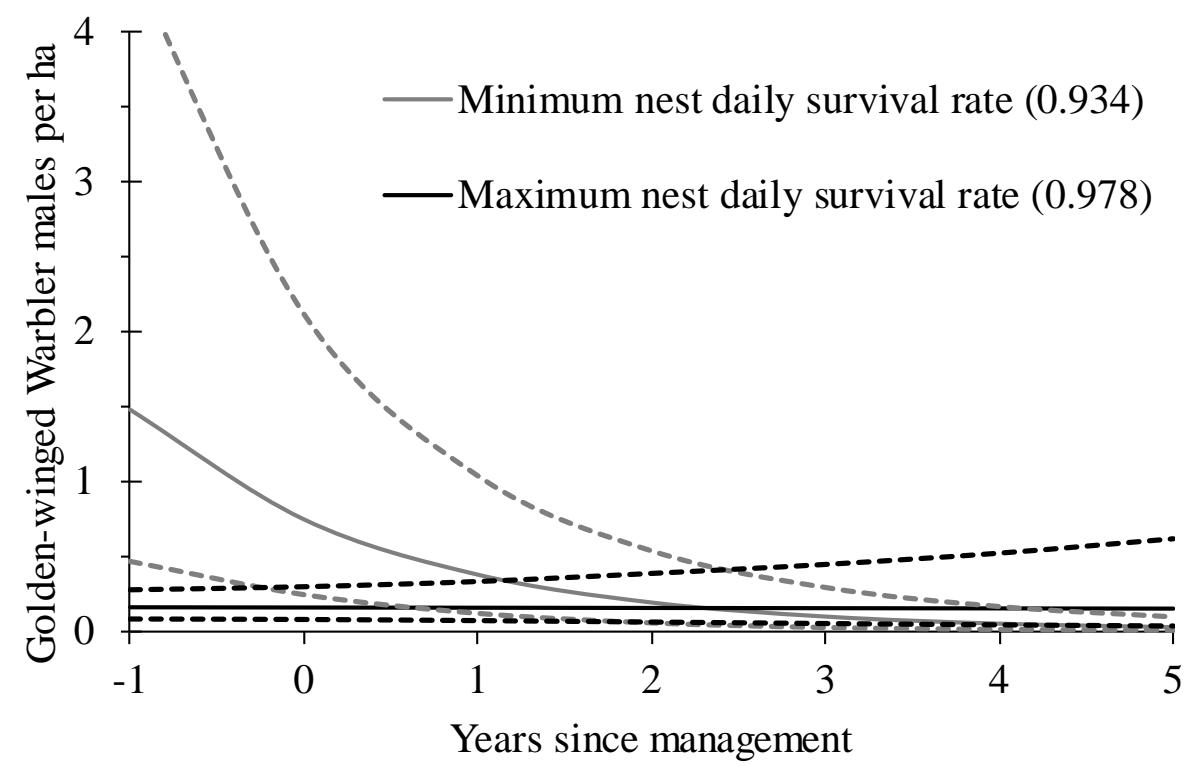

Figure 4. Our only plausible model $\left(\Delta \mathrm{AIC}_{\mathrm{c}} \leq 2.0\right.$, Burnham and Anderson 2002) of Goldenwinged Warbler density included an interaction between nest daily survival rate (DSR) and years since management. Golden-winged Warbler density was negatively correlated with nest DSR and years since management and these two covariates interacted. At the minimum value for nest DSR (0.934, gray line), Golden-winged Warbler density decreased by $50 \%$ per year, while at the maximum value for nest DSR (0.978, black line), Golden-winged Warbler density decreased by only $1 \%$ per year. Dashed lines represent $95 \%$ confidence limits. 